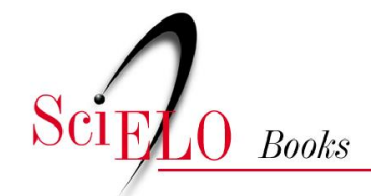

\title{
Internet naf@vela
}

quantos, quem, onde, para quê

\author{
Bernardo Sorj \\ Luís Eduardo Guedes
}

SORJ, B., and GUEDES, LE. Internet na f@vela: quantos, quem, onde, para quê [online]. Rio de Janeiro: Centro Edelstein de Pesquisa Social, 2008. 159 p. ISBN 978-85-99662-46-5. Available from SciELO Books <http://books.scielo.org>.

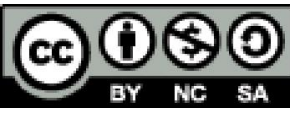

All the contents of this chapter, except where otherwise noted, is licensed under a Creative Commons Attribution-Non Commercial-ShareAlike 3.0 Unported.

Todo o conteúdo deste capítulo, exceto quando houver ressalva, é publicado sob a licença Creative Commons Atribuição Uso Não Comercial - Partilha nos Mesmos Termos 3.0 Não adaptada.

Todo el contenido de este capítulo, excepto donde se indique lo contrario, está bajo licencia de la licencia Creative Commons Reconocimento-NoComercial-CompartirIgual 3.0 Unported. 


\title{
INTERNET NA F@VELA: quantos, quem, onde, para quê
}

\author{
Bernardo Sorj \\ Luís Eduardo Guedes
}


Esta publicação é parte da Biblioteca Virtual de Ciências Humanas do Centro Edelstein de Pesquisas Sociais www.bvce.org

Copyright (c) 2008, Bernardo Sorj e Luís Eduardo Guedes

Copyright (C) 2008 desta edição on-line: Centro Edelstein de Pesquisas Sociais

Ano da última edição: 2005

Nenhuma parte desta publicação pode ser reproduzida ou transmitida por qualquer meio de comunicação para uso comercial sem a permissão escrita dos proprietários dos direitos autorais. A publicação ou partes dela podem ser reproduzidas para propósito não-comercial na medida em que a origem da publicação, assim como seus autores, seja reconhecida.

ISBN 978-85-99662-46-5

Centro Edelstein de Pesquisas Sociais www.centroedelstein.org.br

Rua Visconde de Pirajá, 330/1205

Ipanema - Rio de Janeiro - RJ

CEP: 22410-000. Brasil

Contato: bvce@centroedelstein.org.br 


\section{Sumário}

$\begin{array}{ll}\text { Prefácio } & 03\end{array}$

1 - Introdução $\quad 04$

1.1 - A exclusão digital é múltipla $\quad 04$

1.2 - Evidência empírica $\quad 07$

1.2.1 - Universo de usuários $\quad 07$

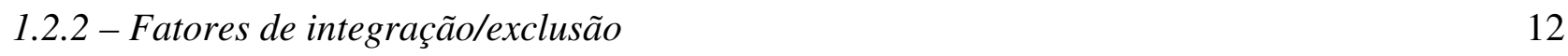

$\begin{array}{ll}1.2 .3 \text { - Qualidade de acesso } & 20\end{array}$

2 - Primeira parte 23

2.1 - Quantos possuem computador no domicílio 23

2.2 - Relação com renda e escolaridade $\quad 26$

2.3 - Posse, propriedade e uso 29

2.4 - Usuários de computador 29

2.5 - Faixa etária, gênero e raça 36

2.6 - Quem e quantos usam Internet

2.7 - Como o e-mail é utilizado $\quad 60$

2.8 - Telecentros: o caso das Estações Futuro $\quad 65$

3 - Segunda parte $\quad \mathbf{7 4}$

3.1 - Análise por tipo de favela $\quad 74$

3.2 - Análise dos usuários de informática e de Internet $\quad 80$

3.3 - Diferenças por gênero $\quad 100$

3.4 - Análise por faixa etária 110

3.5 - Análise por cor $\quad 119$

3.6 - Análise por faixa de renda 126

3.7 - Análise por faixa de instrução 131

3.8 - Análise por tipo de escola 139

3.9 - Estação Futuro $\quad 145$

4 - Conclusões: políticas públicas e inclusão digital 152

Anexo I - Representatividade do universo da pesquisa 156

$\begin{array}{ll}\text { Anexo II - Perfil dos grupos focais } & 158\end{array}$ 


\section{Prefácio}

Este trabalho procura avançar na elaboração de políticas públicas, a partir de uma análise empírica da dinâmica de inclusão/exclusão digital nos setores mais pobres da população, tendo como base uma ampla pesquisa quantitativa e qualitativa nas comunidades de baixa renda, no município do Rio de Janeiro. O survey foi realizado em duas etapas, no segundo semestre de 2003, com 1510 entrevistas, num universo de cerca de um milhão e duzentas mil pessoas. Para complementar a pesquisa, foram realizadas reuniões com oito grupos focais, com amostras das várias faixas etárias e de gênero ${ }^{1}$.

\footnotetext{
${ }^{1}$ No primeiro survey, foi realizado um levantamento com um universo representativo do conjunto dos habitantes das favelas. No segundo, foram pesquisadas seis favelas, duas de renda média mais alta, duas de renda média intermediária e uma de renda media baixa, utilizando-se um questionário mais detalhado. Enquanto no primeiro survey foi incluída a população acima de 15 anos que utiliza, ou não, microcomputadores, no segundo foram incluídas crianças a partir de 10 anos, e todos os entrevistados deveriam fazer uso do microcomputador, de forma a aprofundar o conhecimento deste universo.
} 


\section{1 - Introdução}

\section{1 - A exclusão digital é múltipla}

Neste estudo, a exclusão digital se refere às conseqüências sociais, econômicas e culturais de uma distribuição desigual quanto ao acesso a computadores e Internet, excluindo-se o acesso à telefonia. Embora o telefone pertença ao mesmo grupo de produtos de IC (Informática e Comunicação) compartilhando, inclusive, da mesma infra-estrutura, quando considerado em uma perspectiva sociológica possui características bastante diferentes. Os telefones são parte da família de produtos "inclusivos para analfabetos" - isto é, produtos que podem ser utilizados por pessoas tecnicamente sem qualquer escolaridade -, enquanto computadores e Internet exigem um mínimo, em termos de nível educacional. Se a futura convergência de tecnologias levar ao uso de telefones celulares para transmissão de leitura de mensagens escritas, teremos possivelmente novas formas de desigualdade dentre os usuários de telefones.

Este artigo focalizará aspectos do acesso individual a computadores e Internet, tema que está relacionado ao uso das Tecnologias da Informação e da Comunicação (TICs) como um instrumento de desenvolvimento e crescimento econômico, mas não pode ser com ele confundido. Embora a maior parte da bibliografia sobre exclusão digital, produzida por organizações internacionais, enfatize o potencial das TICs para reduzir a pobreza e a desigualdade, na prática a dinâmica social funciona em sentido inverso: a introdução de novas TICs aumenta a exclusão e a desigualdade social. A universalização do acesso é, antes de tudo, um instrumento para diminuir os danos sociais, do ponto de vista da luta contra a desigualdade. Por quê? 
a) Porque a pobreza não é um fenômeno isolado. Ela é definida e percebida, dependendo do nível de desenvolvimento cultural/tecnológico/político de cada sociedade. A introdução de novos produtos (como telefone, eletricidade, geladeira, rádio ou TV), que passam a ser um indicativo de condição de vida "civilizada", aumenta o patamar dos bens considerados necessários, abaixo do qual uma pessoa ou família é considerada pobre. Como o ciclo de acesso a novos produtos começa com os ricos, para se estender aos pobres após um período mais ou menos longo (e o ciclo nem sempre se completa), a introdução de novos produtos essenciais aumenta a desigualdade.

b) Porque, sendo os ricos os primeiros a usufruir as vantagens do uso e/ou domínio dos novos produtos, eles melhoram suas condições competitivas, enquanto a carência desses produtos aumenta as desvantagens dos grupos excluídos.

Em ambos os casos, novos produtos TICs aumentam a pobreza e a exclusão digital. Políticas públicas podem aproveitar as novas tecnologias para melhorar as condições de vida do conjunto da população, e dos mais pobres, mas a luta contra a exclusão digital busca, primordialmente, encontrar caminhos para diminuir o impacto negativo dessas tecnologias sobre a distribuição de riqueza e oportunidades de vida.

Freqüientemente, os estudos mais aprofundados sobre a exclusão digital têm como foco pequenas comunidades ou experiências locais, e têm valor limitado, pois em geral apresentam pouca ou nenhuma interface com os estudos baseados em dados quantitativos ${ }^{4}$. Por sua vez os estudos estatísticos, em particular os relativos a países em desenvolvimento, têm com parâmetro central, e geralmente único, a divisão entre os que têm e os que não têm acesso à informática e à Internet, em casa. Embora esta seja uma medida importante, é insuficiente para entender a dinâmica social da exclusão digital e definir políticas de universalização de acesso, pois apresenta três grandes limitações:

\footnotetext{
${ }^{4}$ É bastante comum haver uma oposição entre estudos quantitativos, realizados geralmente por economistas, e trabalhos qualitativos, realizados por sociólogos e antropólogos.
} 
a) Não identifica a qualidade do acesso, seja em termos de velocidade da conexão seja do custo/tempo disponível de acesso, em particular para os grupos mais pobres da população.

b) Quando diferenciam camadas socioeconômicas, os estudos quantitativos supõem como universo de usuários aqueles que possuem computador no domicílio.

c) Não oferecem pistas sobre a diversidade de usos e a relevância da inclusão digital para os usuários. Este ponto, embora central, será tratado em detalhe na segunda parte do livro, não sendo objeto desta apresentação..

A exclusão digital não se refere a um fenômeno simples, ou seja, aqueles que têm versus aqueles que não têm acesso a computador e Internet, incluídos e excluídos, polaridade real mas que por vezes mascara os múltiplos aspectos da exclusão digital. A razão disto é simples: a oposição acesso/não acesso é uma generalização razoável, quando se trata de serviços públicos ou de bens de consumo intermediário tradicionais (embora os tipos de TV, geladeira, carro possam ser melhores ou piores e, para a população pobre, o custo da ligação limita sobremaneira o uso de telefone, assim como o custo da gasolina, o uso do carro).

O número de proprietários de computador, ou de pessoas com acesso á Internet, é uma medida primitiva demais para aferir a exclusão digital. Por quê? a) porque o tempo disponível e a qualidade do acesso afetam, decisivamente, o uso da Internet; b) porque as tecnologias de informação e comunicação (em diante telemática) são muito dinâmicas e obrigam a uma freqüente atualização de hardware, software e dos sistemas de acesso que, para não ficarem obsoletos, exigem investimentos constantes por parte do usuário; c) porque seu potencial de utilização depende da capacidade de leitura e interpretação da informação, por parte do usuário (no caso da Internet) e de sua rede social (no caso do e-mail). 
A seguir, apresentamos alguns dos principais resultados da pesquisa e suas implicações para a elaboração de políticas e projetos sociais de inclusão digital. Devemos ressaltar que, neste trabalho, enfatizamos a inclusão digital de indivíduos. Outros aspectos também deverão ser considerados, em certos contextos, pois a inclusão digital de instituições comunitárias pode melhorar a qualidade de vida de populações pobres, em particular daquelas espacialmente isoladas, oferecendo serviços e informações de valor cultural, econômico e social.

\section{2 - Evidência empírica}

\subsection{1 - Universo de usuários}

Considerando-se um determinado país, geralmente define-se a inclusão digital pela porcentagem de pessoas, no total da população, com acesso a computador e/ou Internet no domicílio. ${ }^{5}$ Para identificar as pessoas incluídas, o critério em geral utilizado é o numero de computadores por domicílio e/ou de computadores por domicílio, com acesso à Internet. Esta metodologia já foi alvo de críticas, pois em certos países, com um número relevante de pontos de acesso coletivo (comumente denominados telecentros ou cybercafés), a quantidade de pessoas que acessam a Internet por computador é muito maior que a média de acesso por domicílio. Argumenta-se também

que famílias de classe média normalmente possuem mais de um computador por domicílio, fato que não ocorre entre as famílias pobres. Isto significaria um maior número de usuários por computador entre as famílias pobres e um número menor, entre as famílias de classe média.

No caso brasileiro, o impacto estatístico dos telecentros é secundário, dado que seu número, em escala nacional, ainda é relativamente pequeno, embora, como veremos, está longe de ser insignificante para as comunidades onde eles se localizam. Por sua vez, a expectativa de um maior número de usuários por computador no domicílio, no caso de famílias pobres, deve ser qualificada, já que, como indica a nossa pesquisa, na maioria das famílias pobres, são poucos os membros que usam computador. 
Como mostram os dados a seguir, a quantificação da inclusão digital a partir do número de computadores por domicílio produz uma visão totalmente errônea sobre o acesso à informática e à Internet, por parte dos setores mais pobres da população. Isto não só porque apenas a metade dos que possuem computador têm acesso à Internet no domicílio, mas sobretudo porque, para os usuários de Internet nas favelas, o local de trabalho e casas de terceiros constituem o principal lugar de acesso.

De acordo com a pesquisa, 9,0\% dos domicílios localizados nas favelas possuem computador.

\section{Gráfico 1.2.2.1: Posse de computador no domicílio, nas comunidades do município do Rio de Janeiro}

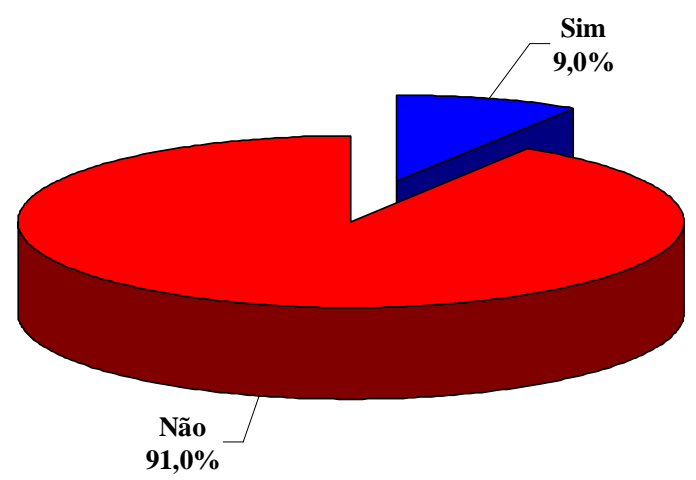

$\mathrm{O}$ acesso à informática nas favelas é superior à média de muitas capitais do Norte e Nordeste do país. Se, por um lado, a posse de computador, nas favelas do Rio de Janeiro, está próxima à média nacional, por outro lado ela é 30,0\% inferior à média do estado e, tomando-se como referência seu ambiente direto, o Município do Rio de Janeiro, apresenta a relação de 1 para 2.6 computadores (comparando-se favelas e bairros mais ricos, a relação passa a ser em torno de 1 para 6).

\footnotetext{
${ }^{5}$ Como o faz, por exemplo, o Mapa da Exclusão Digital ,da Fundação Getulio Vargas: http://www2.fgv.br/ibre/cps/mapa_exclusao/apresentacao/apresentacao.htm
} 
Gráfico 1.2.2.2: Comparação entre as taxas de inclusão digital das comunidades de baixa renda do município do Rio de Janeiro e de algumas capitais

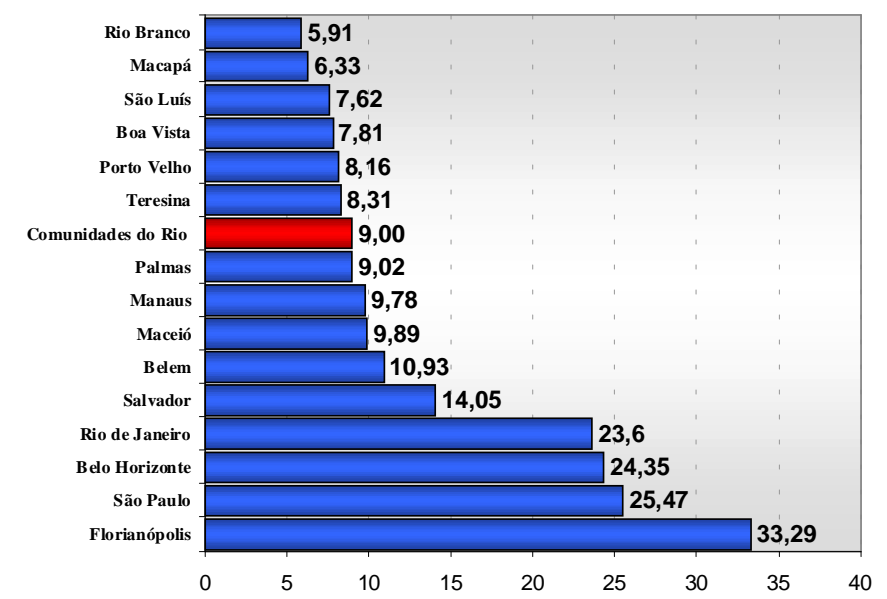

Nota: Inclusão Digital, neste caso, refere-se à porcentagem de computadores no total de domicílios.

O processo desigual de disseminação do computador entre a população de diferentes cidades do Brasil reflete, sem dúvida, as desigualdades no nível de riqueza e de escolaridade das diversas regiões e cidades do país, em particular das populações pobres das regiões Norte e Nordeste, quando comparadas ao Centro-Sul. Mas a posse do computador está também associada a um componente intangível: a disseminação de uma cultura de valorização da informática, associada em particular à noção de que seu domínio é condição de emprego e sucesso na educação. Em outras palavras, à proporção que o sistema produtivo se informatiza, a noção de que é necessário dominar o computador para assegurar maiores chances de trabalho infiltra-se rapidamente entre os diversos setores sociais, pois o uso da informática passa a ser visto como condição de obtenção de trabalho e de sucesso escolar. De fato, a única pergunta cuja resposta é consensual, independentemente de nível educacional, renda, cor ou gênero, é aquela que se refere à importância do conhecimento de informática para a obtenção de emprego: a quase totalidade dos entrevistados indicou que ela ajuda a conseguir trabalho. Portanto, se a disseminação do computador tem uma óbvia correlação com o níveis de renda e de escolaridade, ela está igualmente associada aos padrões culturais mais amplos de informatização da sociedade.

A exclusão digital se dá também no interior dos grupos pobres, entre gêneros, raças e grupos etários, assim como entre diferentes comunidades. A menção aos bairros pobres 
pode dar uma visão homogênea destes, mas tanto no interior de cada bairro pobre como entre eles, a desigualdade quanto à posse de computador é muito pronunciada:

Gráfico 1.2.1.3: Comparação entre as taxas de inclusão digital de comunidades de baixa renda do município do Rio de Janeiro e de outros municípios do estado

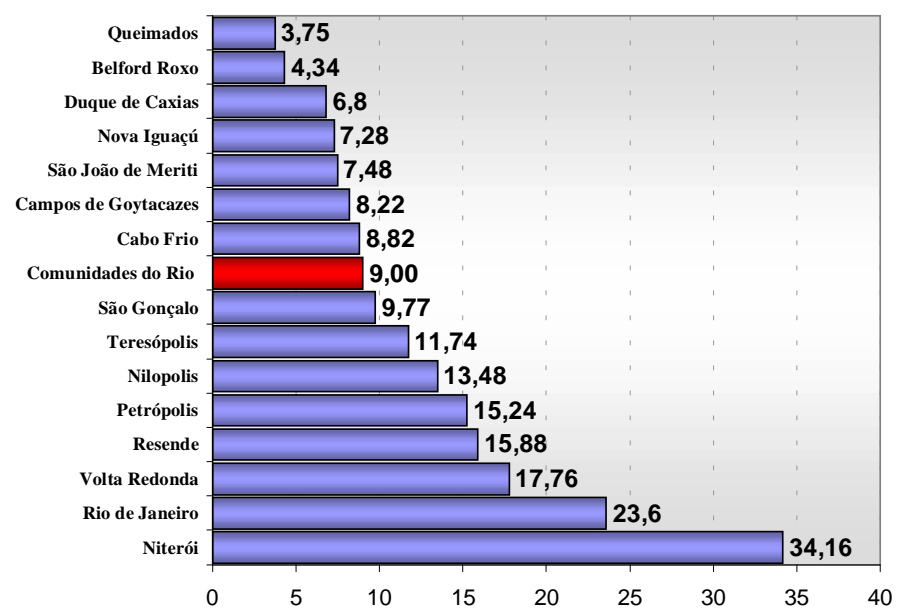

Nota: Inclusão Digital, neste caso, refere-se à porcentagem de domicílios com computador.

Porém o número de pessoas com computador no domicílio não define o número de usuários, que é o dobro daqueles que o possuem:

Gráfico 1.2.1.4: Percentual de pessoas que possuem e que utilizam microcomputadores nas comunidades de baixa renda do município do Rio de Janeiro

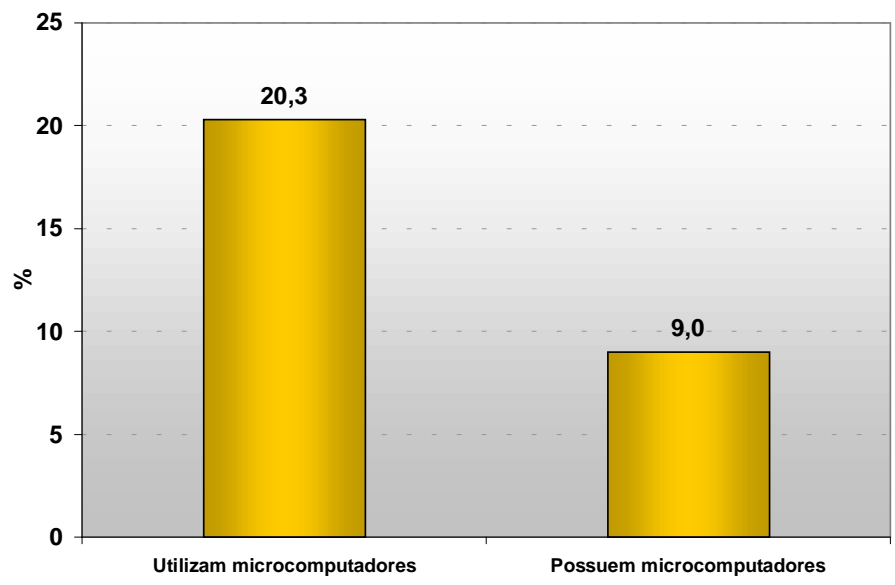


Uma explicação possível para o fato de o número de usuários de computador ser maior do que o de domicílios com computador é que cada micro, seria utilizado por vários membros da família. Mas esta explicação é insuficiente, pois somente $27.6 \%$ dos entrevistados indicaram o domicílio como principal local de uso do computador. Não só as entrevistas individuais, mas também as dos grupos focais indicam que o computador geralmente é visto como um bem de consumo pessoal, embora posse e propriedade não fiquem claramente definidas. Muitos, em particular os jovens, definem os computadores como seus, embora tenham sido comprados pelos pais. A questão da posse está associada diretamente à utilização, pois, em geral, o usuário quem define o computador como seu. A tendência a se individualizar a propriedade do computador está associada tanto ao fato de que muitos membros da família não usarem o computador, como à vontade de afirmar a posse, dado o conflito sobre os horários de utilização, tema que foi indicado, nos grupos focais, como gerador de tensões na família.

O número maior de usuários em relação aos proprietários é conseqüência principalmente do fato de, o acesso nas favelas, o domicilio nao ser principal local de acesso ao computador:

Gráfico 1.2.1.5: Principal local de utilização do microcomputador nas comunidades de baixa renda do município do Rio de Janeiro

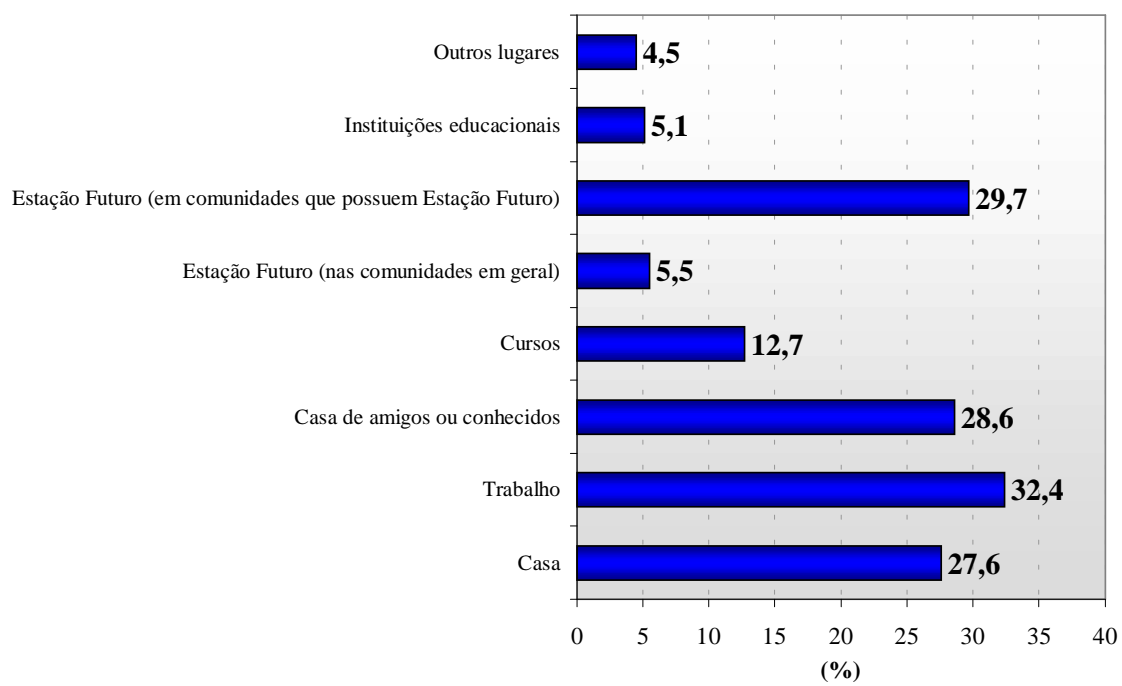

O trabalho, e não o domicílio, representa para os habitantes da favela o principal local de utilização de computador, seguido por casa de amigos e de conhecidos, 
ficando o domicílio em terceiro lugar. Nas favelas onde existem Estações Futuro (telecentros) da ONG Viva Rio, elas são o segundo local de acesso para quase $30 \%$ dos usuários de informática. Estes dados contradizem a expectativa de que, nos setores mais pobres da população, o número de usuários por computador no domicílio é alto, pois em geral são poucos os membros da família que utilizam computador, geralmente dependentes e menores de idade.

Este fenômeno de dissociação entre posse de computador e usuários se reproduz em relação à Internet. Embora somente a metade dos que possuem computador no domicílio tenha acesso à Internet, o número de usuários de Internet é maior do que o triplo daqueles que têm acesso no domicilio.

Gráfico 1.2.1.6: Percentual de pessoas que possuem e que utilizam microcomputadores e Internet, nas comunidades de baixa renda do município do Rio de Janeiro

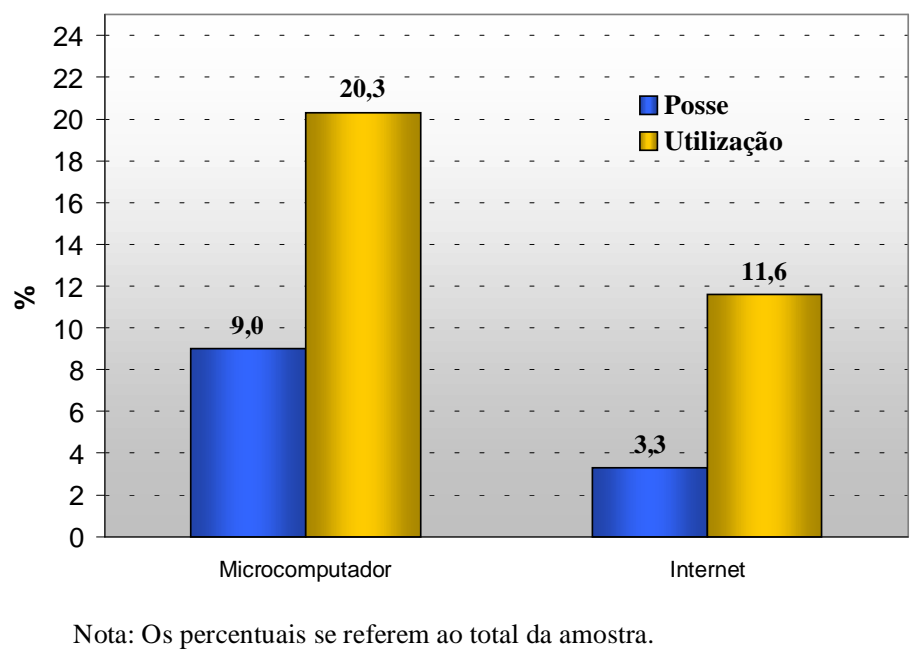

\subsection{2 - Fatores de integração/exclusão}

Entre os usuários de informática na favela, como em geral no conjunto da população, existe uma tendência decrescente ao uso da informática, à proporção que se avança na faixa de idade. $\mathrm{Na}$ favela, esta tendência se acentua, devido a níveis de escolaridade mais baixos, entre os mais idosos, e a menores chances de no emprego: 
Gráfico 1.2.2.1: Percentual de utilização do microcomputador, segundo a faixa de idade

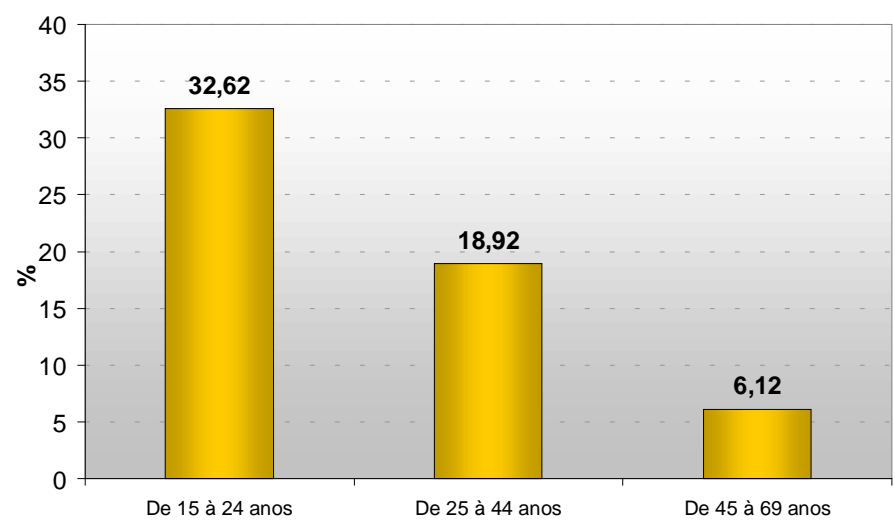

Nota: Os percentuais foram calculados em relação ao próprio grupo.

Como era de se esperar, os gráficos a seguir indicam uma clara correlação entre nível de ingresso, educação e posse de computador. O nível escolar é fundamental: entre as pessoas com 1 a 3 anos de estudo, encontramos 2 computadores cada 100 domicílios; na faixa daqueles com mais de 15 anos de estudo, a posse do computador chega a 48.9 cada 100 domicílios:

Gráfico 1.2.2.2: Renda pessoal e familiar per capita média, segundo a posse de Microcomputador, nas favelas do município do Rio de Janeiro

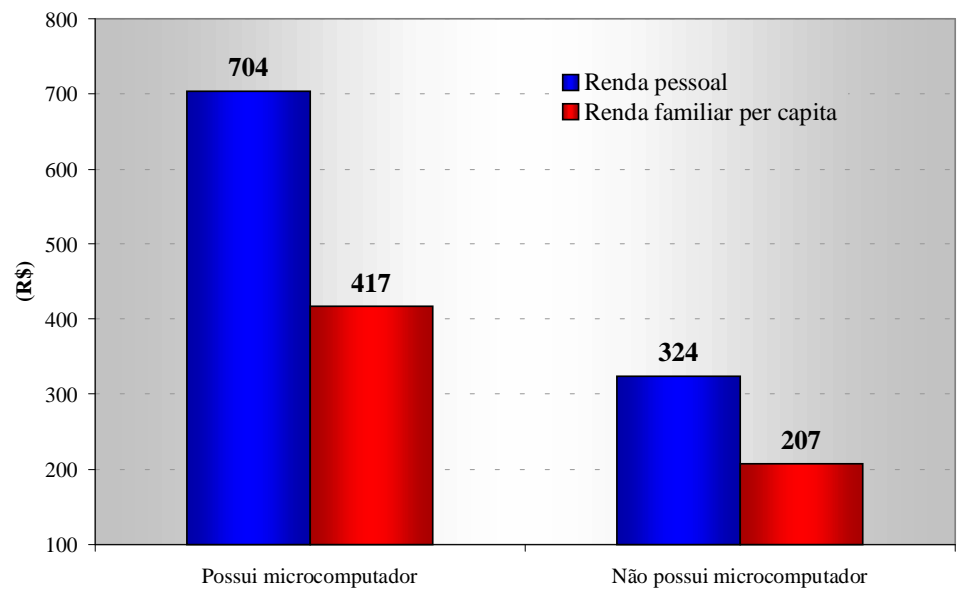


Gráfico 1.2.2.3: Percentual de pessoas que possuem computador no domicílio, por faixa de anos de estudo, nas favelas do município do Rio de Janeiro

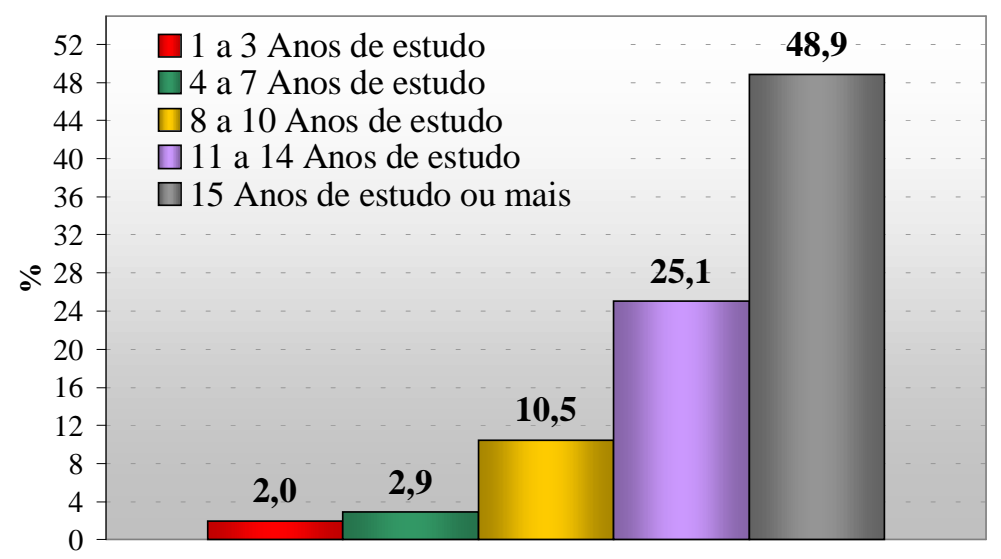

É importante assinalar que o fato que sejao principal ponto base de acesso (e de aprendizagem e motivação de uso) ao computador e a Internet ser o local de trabalho, e não o domicílio, não somente muda de forma relevante o número de pessoas digitalmente incluídas, como transforma o perfil do usuário.

Como veremos a seguir, leva a que as mulheres, pelo tipo de trabalho que realizam, são em geral empregadas domésticas ou fazem serviços de limpeza - sejam as mais prejudicadas e apresentem um nível de exclusão digital muito mais alto que os homens, nas camadas pobres da população., Por outro lado a população negra masculina, que apresenta uma média de posse de computador por domicílio bastante inferior à população branca da favela, encontra no trabalho um mecanismo de igualação social. Assim, o acesso à informática fora do domicílio tem, geralmente, um impacto democratizador, ainda que desigual, permitindo que pessoas com ingresso médio e nível educacional mais baixo entrem no mundo da informática.

Entre os usuários de computador, dentro ou fora do domicílio , o padrão que associa ingresso ao uso de informática se mantém, mas a distância tende a diminuir, indicando que as pessoas com um nível de escolaridade mais baixo encontram, no uso de computadores fora do domicílio, um mecanismo de igualação social: 
Gráfico 1.2.2.4: Percentual de pessoas que possuem e utilizam microcomputador por faixa de anos de estudo, nas comunidades do município do Rio de Janeiro

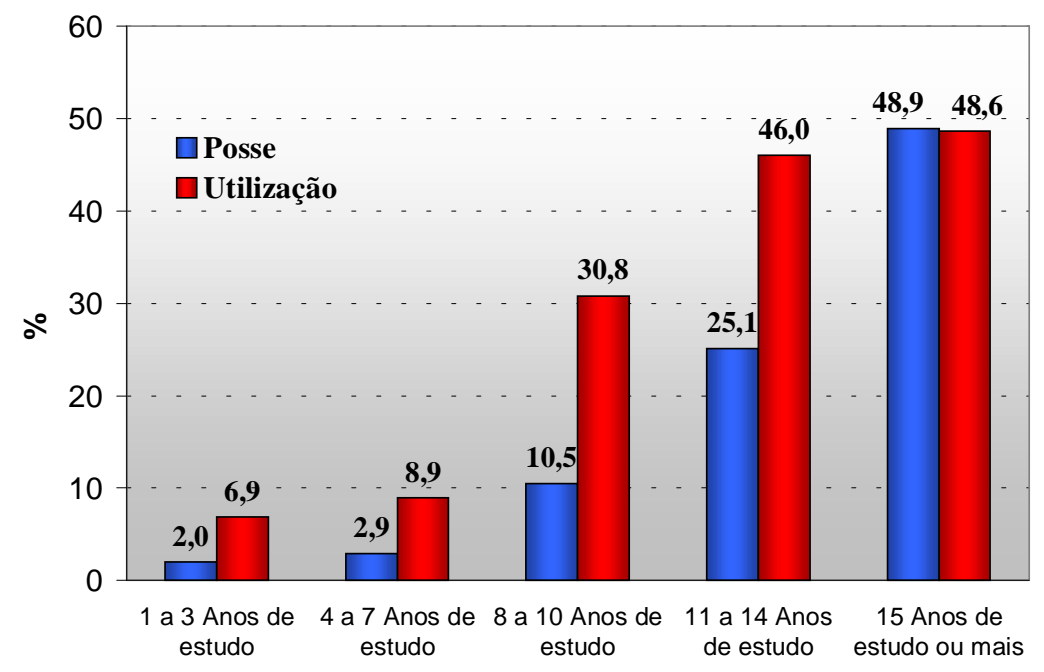

Nota: Os percentuais foram calculados em relação ao próprio grupo.

O mesmo vale para o nível de renda:

Gráfico 1.2.2.5: Renda familiar per capita, segundo a posse e utilização de microcomputador

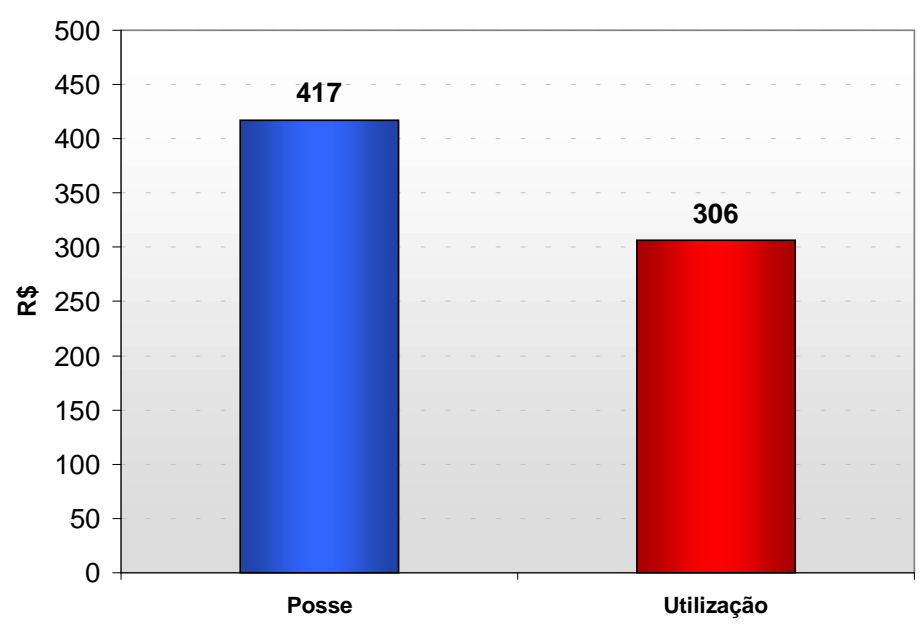


Como mostra o gráfico 1.2.2.6, enquanto o percentual de pessoas brancas com posse de computador supera a média $(9.0 \%)$, e os pardos a igualam, a população negra apresenta um nível de posse equivalente à metade da média.

Gráfico 1.2.2.6: Percentual de pessoas que possuem computador no domicílio, por cor/raça, nas comunidades do município do Rio de Janeiro

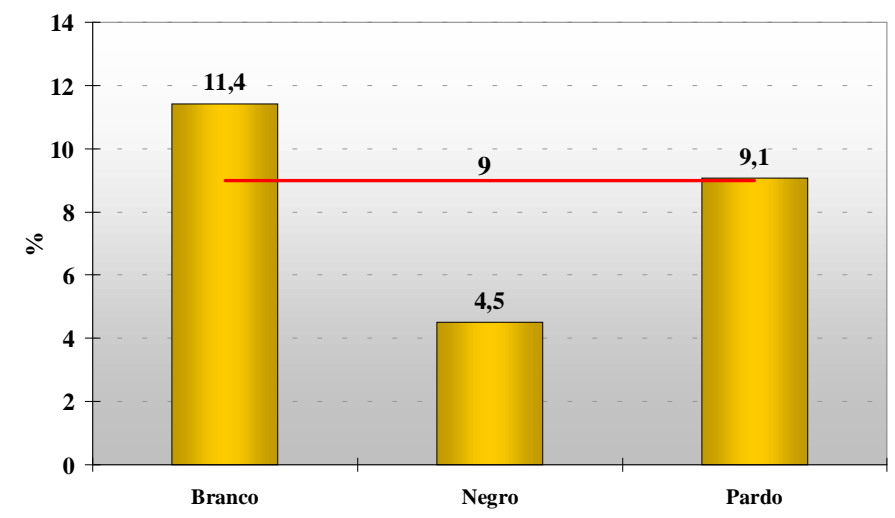

Nota: Os percentuais foram calculados em relação ao próprio grupo.

Como indica o gráfico 1.2.2.7, essa situação reflete a posição duplamente desfavorecida da população negra, em termos de renda e educação:

\section{Gráfico 1.2.2.7: Comparação entre as médias de renda familiar per capita}

e anos de estudo

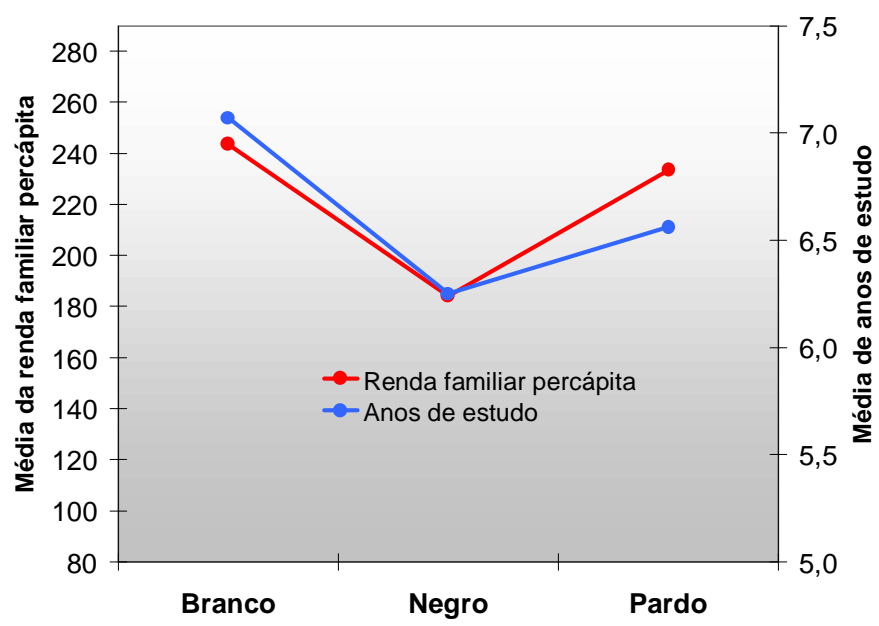

Vale ressaltar que, em termos de usuários de informática, a diferença acima tende a diminuir, graças a outros acessos fora do domicílio: 
Gráfico 1.2.2.8: Percentuais de posse e utilização de microcomputador, segundo a cor

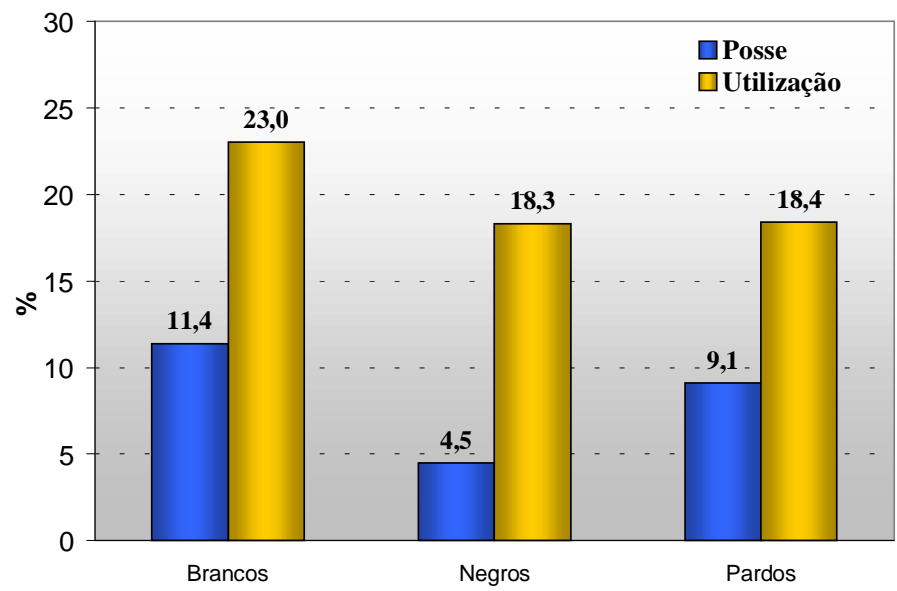

Nota 1: Os percentuais foram calculados em relação ao próprio grupo.

Nota 2: Foi usado o universo dos que utilizam o computador ( $20,3 \%$ da população).

Ou seja, o acesso fora de domicílio funciona como um fator de criação de oportunidades para a população negra. O oposto acontece com a população feminina:

\section{Gráfico 1.2.2.9: Utilização de microcomputadores segundo o sexo, nas comunidades do município do Rio de Janeiro}

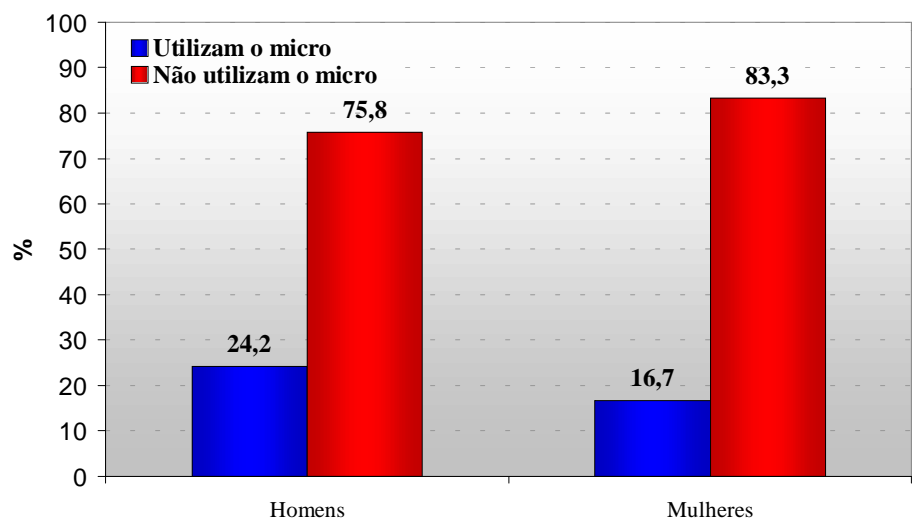

O que acontece em ambos os casos, ou seja, baixo acesso das mulheres e incremento do percentual da população negra de usuários? $\mathrm{O}$ trabalho atua como fator de exclusão digital no caso das mulheres, e de igualação social no caso dos negros, como já mencionado anteriormente. A maioria das mulheres trabalha em serviços de limpeza ou como empregadas domésticas, não tendo oportunidade de utilizar computador, enquanto um número maior de homens, inclusive muitos que trabalham como office boys, acabam 
convivendo em ambientes que incentivam, e por vezes permitem, o conhecimento de usos básicos do computador.

As tendências quanto ao uso de computadores se reproduzem em relação à Internet, e até ficam mais marcadas. Do total dos possuidores de computador, somente um terço tem acesso à Internet, de forma que, do total de usuários de Internet, pouco mais de $25 \%$ acessam-naa partir domicílio, reproduzindo os padrões de uso de computador mencionados acima, isto é, a principal fonte de acesso se encontra fora do domicílio.

\section{Gráfico 1.2.2.10: Locais de acesso à Internet mais utilizados nas comunidades}

do município do Rio de Janeiro

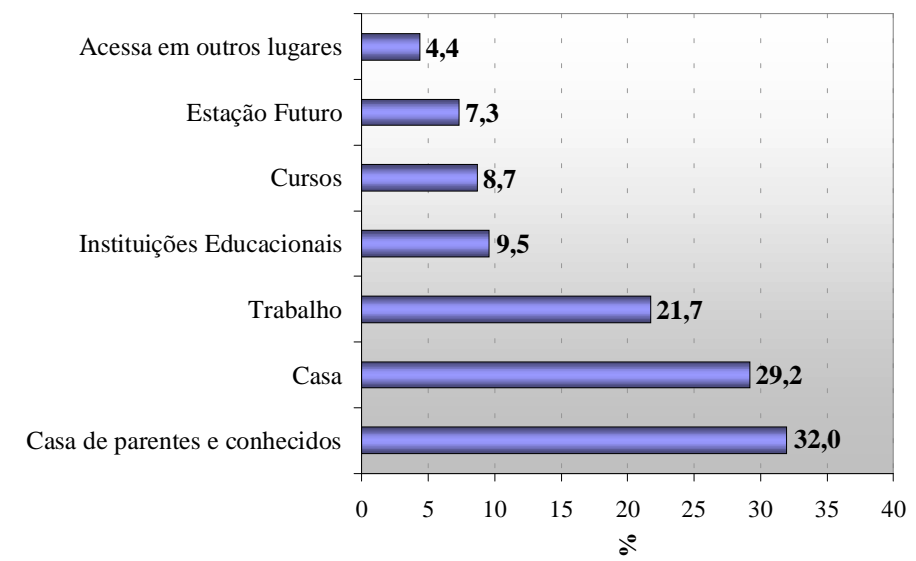

Universo: os que usam a Internet ( $11,6 \%$ da população).

No uso de Internet, a faixa etária ainda é mais decisiva, aumentando sua importância nos setores mais jovens:

Gráfico 1.2.2.11: Percentual de utilização da Internet e computador, segundo a idade

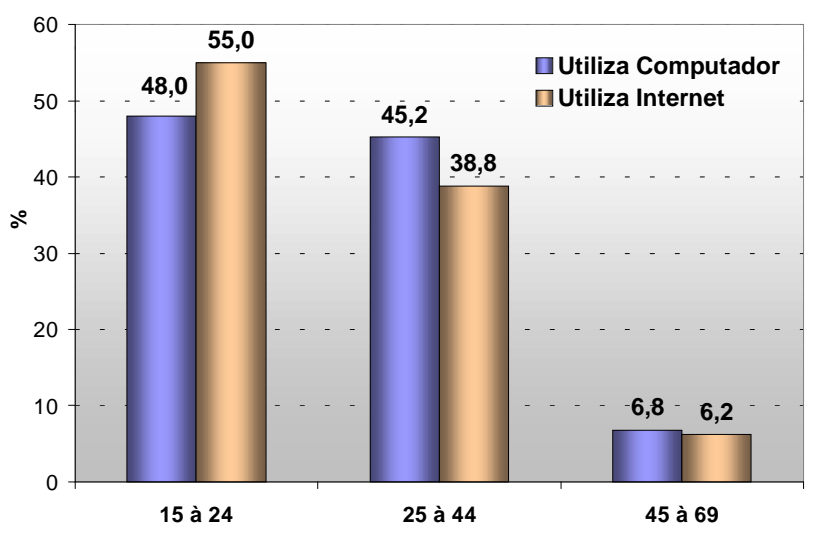

Nota: Os percentuais foram calculados em relação ao próprio grupo. 
A distância entre as rendas maior e menor aumenta visivelmente, quando se passa do grupo de usuários de computador para o de usuários de Internet, o que deve estar relacionado ao custo e à dificuldade de acesso à Internet:

Gráfico 1.2.2.12: Renda domiciliar per capita e renda pessoal, segundo o nível de inclusão digital

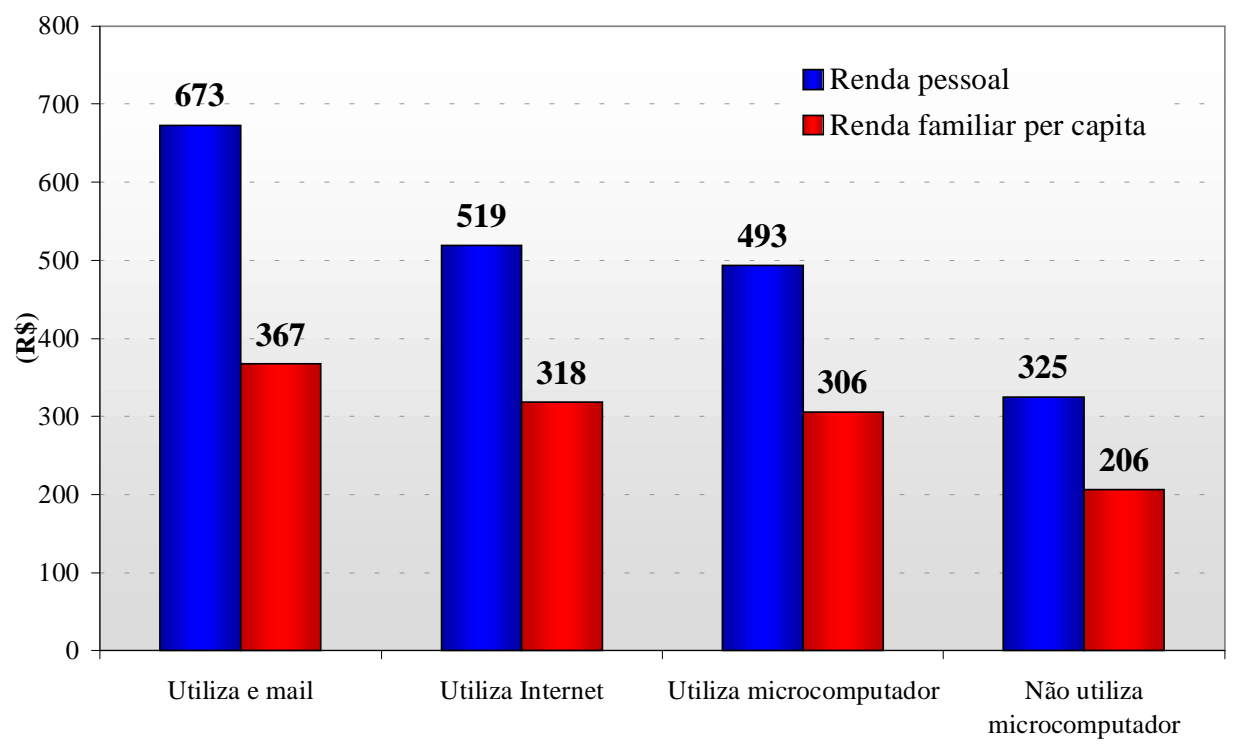

Finalmente, embora não se inclua nestaapresentação uma discussão sobre os usos da Internet, não se pode deixar de indicar um dado que mostra os limites do uso da telemática pelas camadas populares:

Gráfico 1.2.2.13: Percentual de uso de E-mail em relação à utilização de microcomputadores e Internet, no total da população das favelas

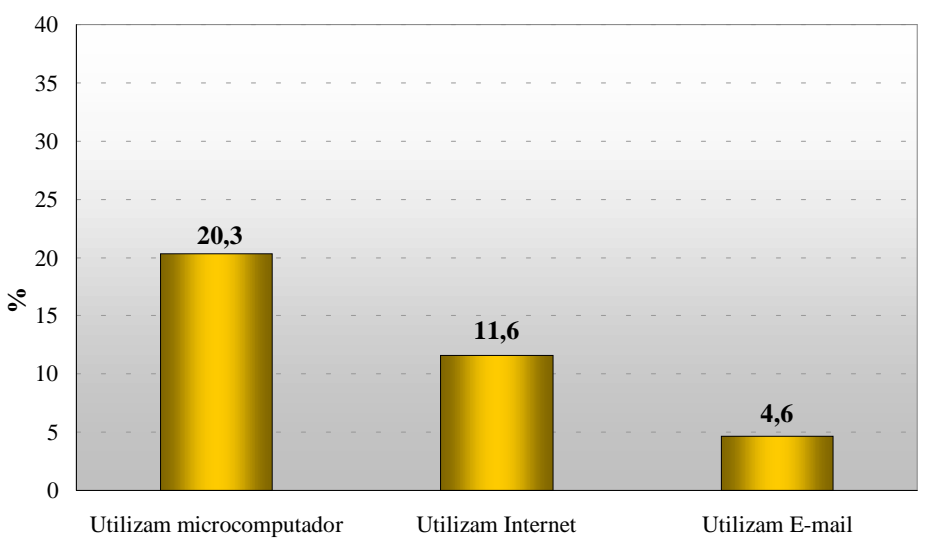


Observamos que significativamente menos da metade dos usuários da Internet utiliza email. Trata-se de uma porcentagem muito baixa, e isto é produto do contexto social dos habitantes das favelas, onde boa parte da rede social não utiliza Internet, fazendo do email um instrumento de comunicação menos útil.

\subsection{3 - Qualidade do acesso}

Se os dados anteriores indicam que os caminhos para utilizar o computador e acessar a Internet são múltiplos, todos eles convergem no sentido de assinalar as limitações do tempo disponível e da qualidade de acesso, pelo usuário de baixa renda:

1) Aqueles que possuem computador e acesso à Internet, em casa, estão limitados pela qualidade de acesso (praticamente sem acesso à banda larga) e o tempo em que podem permanecer ligados (já que utilizam acesso discado, pago por tempo de permanência na linha). O resultado é uma baixa freqüiência de uso.

O não-acesso à Internet rápida com um valor mensal fixo, independentemente do tempo de uso, tem uma dupla conseqüência: a informação demora mais tempo para ser acessada, e o tempo disponível para permanecer na Internet é menor, já que o usuário paga pelo período em que permanece ligado.

Como mostra o gráfico a seguir, a intensidade do uso da Internet entre os habitantes das favelas ainda é bastante baixa. No estudo da exclusão digital, portanto, deve ser considerado não somente o número de usuários e não-usuários, mas também a intensidade de uso da Internet, tanto em relação à qualidade de acesso (baixa ou alta velocidade) como ao tempo efetivamente disponível. 
Gráfico 1.2.3.1: Frequiência de acesso à Internet, nas comunidades do município do Rio de Janeiro

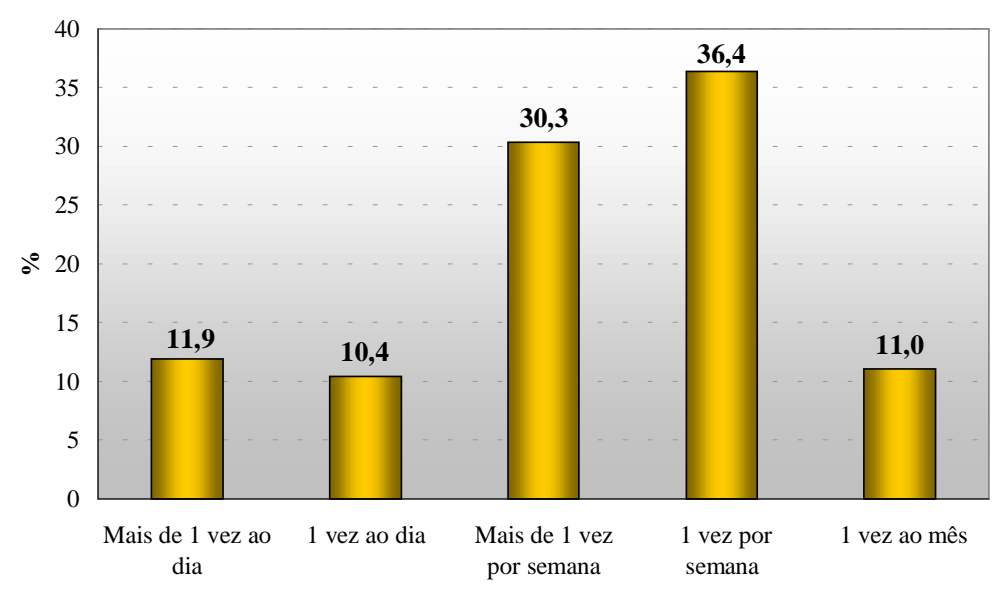

Universo: Usuários de Internet (11,6\% da população).

2) Os que têm acesso à informática e ao computador no trabalho podem utilizar este instrumentos nos limites de suas obrigações e horário de trabalho.

3) Aqueles que se utilizam de telecentros dependem da existência desse recurso nas proximidades, de condições financeiras para pagar o serviço e da disponibilidade de computadores do telecentro em horários de seu interesse.

4) Finalmente aqueles que têm acesso em casa de amigos ou de familiares também enfrentam dificuldades, devido à limitada disponibilidade dos computadores. Finalmente, os usuários das Estação Futuro - telecentros da ONG VivaRio, que oferecem acesso a preços menores - apresentam o mesmo perfil educacional e de ingresso do típico usuário de computador e Internet da favela: 
Gráfico 1.2.3.2: Renda domiciliar per capita e renda pessoal, segundo a utilização de Estação Futuro

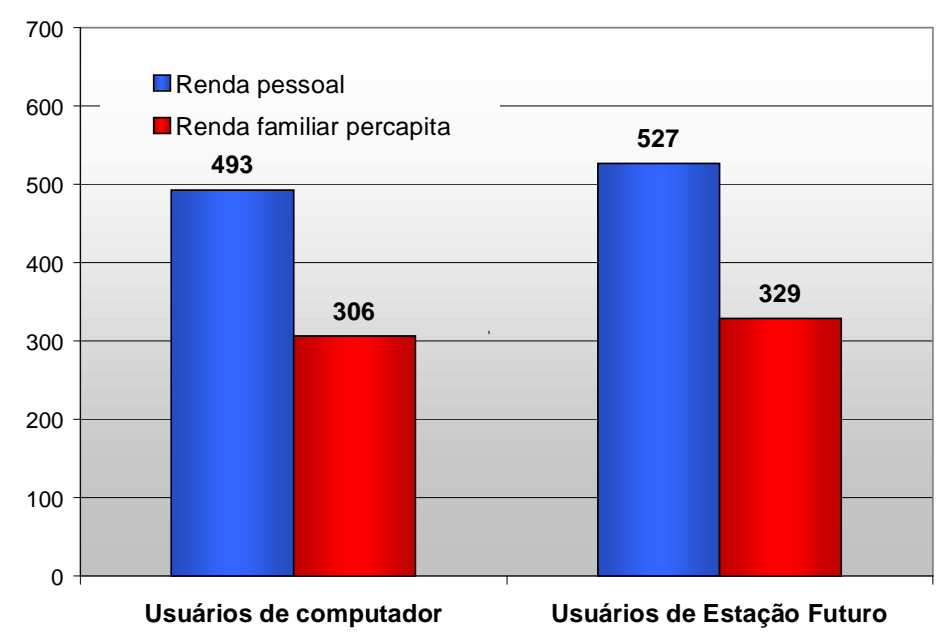

Os telecentros, de toda forma, aumentam a base de usuários e provêem os habitantes da favela, inclusive aqueles que possuem acesso em casa, de melhor qualidade de serviços, infra-estrutura e apoio. ${ }^{6}$ 


\section{2 - Primeira Parte}

\section{1 - Quantos possuem computador no domicílio}

De acordo com a pesquisa, 9\% dos domicílios localizados nas favelas possuem computador. Embora não haja dados quantitativos sobre compra, observou-se nos grupos focais, nos quais $50 \%$ das pessoas possuíam computador, que a maioria havia deles foram compradosdonovos sendo a metade adquirido à vista.

Gráfico 2.1.1: Posse de computador no domicílio, nas comunidades do município do Rio de Janeiro

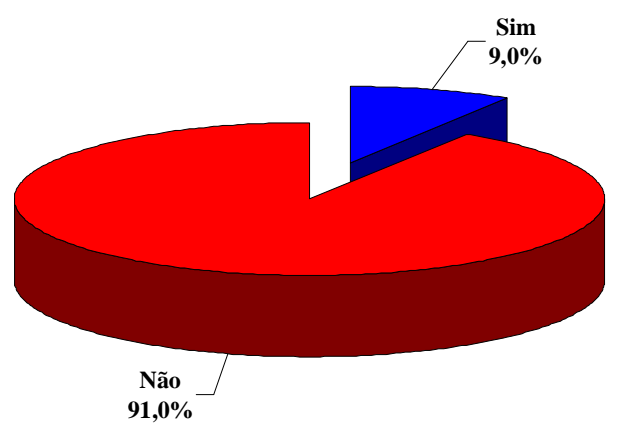

Este dado, se confrontado com a situação nacional, apresenta resultados bastante interessantes:

Gráfico 2.1.2: Comparação entre as taxas de posse de computador das comunidades de baixa renda do Rio, Brasil, Estado e Município do Rio de Janeiro

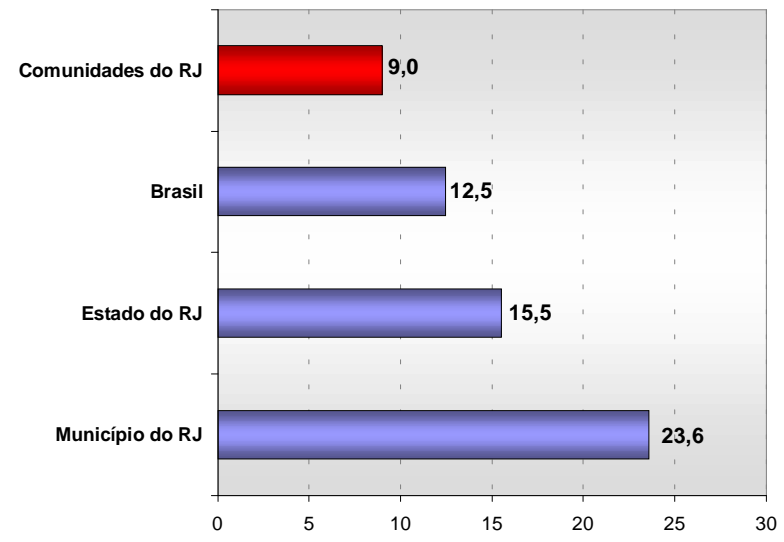

Nota: Inclusão Digital, neste caso, se refere à porcentagem de computadores no total de domicílios.

Observe-se que, se por um lado, a posse de computador, nas favelas do Rio de Janeiro, está próxima à média nacional, por outro lado ela é $30 \%$ inferior à média do estado e, 
tomando-se como referência seu ambiente direto, o Município do Rio de Janeiro, apresenta a relação de 1 para 2.6 computadores (comparando-se favelas e bairros mais ricos, a relação passa a ser em torno de 1 para 6. Assim, embora a desigualdade de acesso seja importante, impressiona a quantidade de proprietários de computador em bairros pobres, o que indica o início de um processo de massificação, quanto a seu uso.

O acesso à informática nas favelas, inclusive, é superior à média de muitas capitais do Norte e Nordeste do país.

Gráfico 2.1.3: Comparação entre as taxas de posse de computador das comunidades de baixa renda do município do Rio de Janeiro e algumas capitais

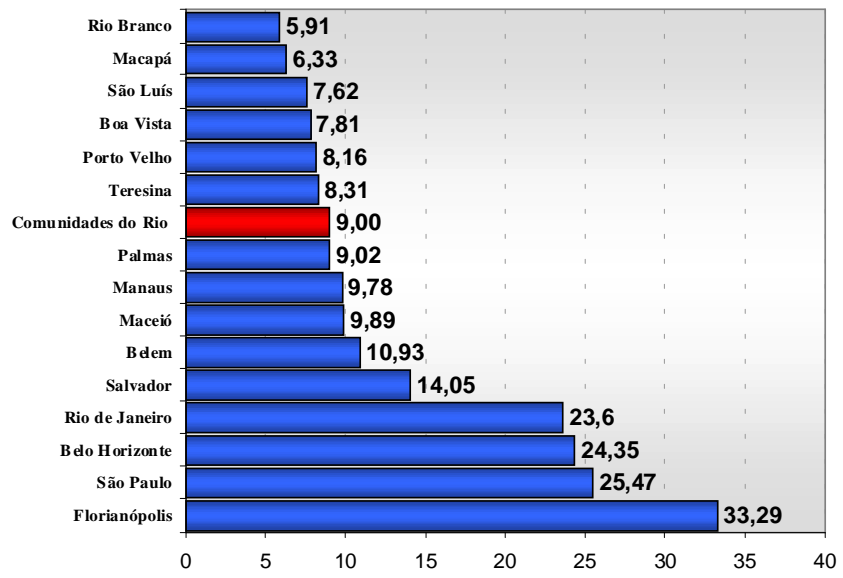

Nota: Inclusão Digital, neste caso, se refere à porcentagem de computadores no total de domicílios.

A explicação para esse fenômeno pode ser encontrada na bibliografia internacional sobre a disseminação do computador: trata-se de um fenômeno predominantemente urbano, em particular das grandes metrópoles, sendo o seu uso associado à disseminação no conjunto da sociedade local, e como veremos, no local de trabalho.

O processo desigual de disseminação do computador entre a população das diferentes cidades do Brasil reflete, sem dúvida, o desigual nível de riqueza e escolaridade entre as diferentes regiões e cidades do país, em particular das populações pobres da região Norte e Nordeste em relação ao Centro-Sul. Mas a posse do computador está também associada a um componente intangível: a disseminação de uma cultura de valorização da informática associada em particular à noção de que seu domínio é condição de emprego e sucesso na educação. Noutras palavras, à proporção em que o sistema 
produtivo se informatiza, a noção de que é necessário dominar este instrumento para assegurar maiores chances de trabalho se "infiltra" rapidamente entre os diversos setores sociais. Algo similar acontece com o uso de computador pelas crianças. À medida que os pais investem na educação de seus filhos (uma prioridade da população pobre urbana, apesar de seus limitados recursos), a informática passa a ser vista como condição de sucesso escolar. A disseminação do computador tem, portanto, uma óbvia correlação com renda e nível de escolaridade, mas está igualmente associada aos padrões culturais mais amplos de informatização da sociedade.

Finalmente, se a posse de computador no conjunto dos municípios pobres da região metropolitana do Rio de Janeiro é relativamente alta, a desigualdade no interior deste conjunto é muito pronunciada:

Gráfico 2.1.4: Comparação entre as taxas de posse de computador das comunidades de baixa renda do município do Rio de Janeiro e algumas municípios do estado

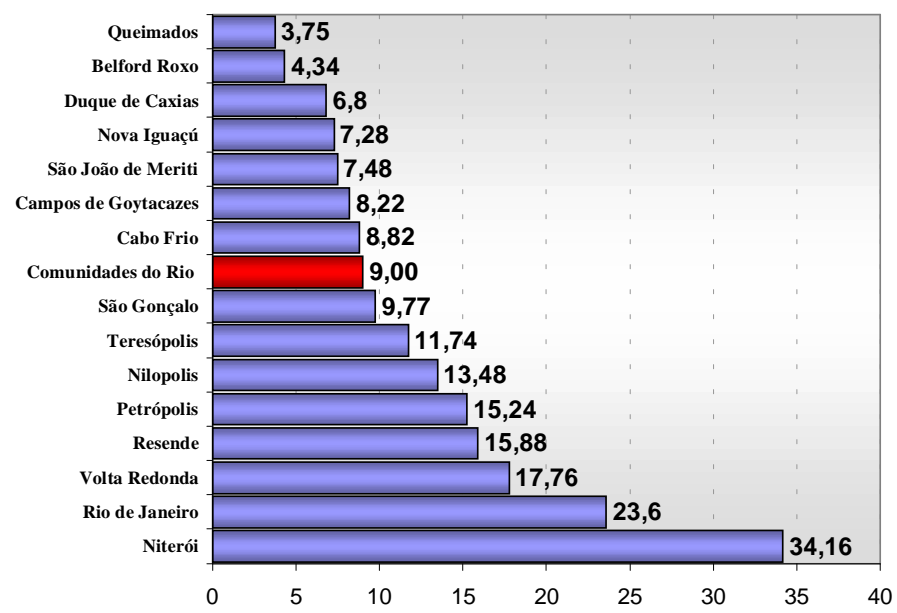

\section{Conserto do computador}

A manutenção do computador é feita normalmente por conhecidos ou amigos da própria comunidade. Pessoas da família que trabalham com micro também são solicitadas a fazer reparos. Poucos procuram serviços autorizados. Um dos entrevistados (homem, entre 22 e 35 anos) declarou que a preferência por pessoa da comunidade deve-se ao preço mais barato dos serviços prestados dentro da comunidade, além de muitos técnicos de fora não quererem entrar na favela por considerá-la área de risco. No entanto, um dos moradores da favela da Rocinha, homem entre 22 e 35 anos, não tem confiança no trabalho feito por pessoas da 
comunidade, devido a uma experiência ruim com o conserto do computador que ele possuía anteriormente. Com isto, caso ele não consiga lidar com o problema do micro, opta por fazer a manutenção na empresa em que trabalhou, especializada em telecomunicações. Ele ressalta que uma das vantagens de se fazer o serviço fora da comunidade é a garantia oferecida, enquanto numa loja na Rocinha lhe ofereceram um teclado para compra, sem essa segurança.

Os que possuem algum conhecimento, inicialmente tentam resolver o problema sozinhos, e apenas quando não o conseguem, ou quando é necessário um conhecimento mais especializado, procuram um técnico da comunidade.

\section{2 - Relação com renda e escolaridade}

A posse de computador está associada, em primeiro lugar, aos níveis de renda e de escolaridade:

Gráfico 2.2.1: Renda Pessoal e Familiar per capita média, segundo a posse de Microcomputador, nas favelas do município do Rio de Janeiro

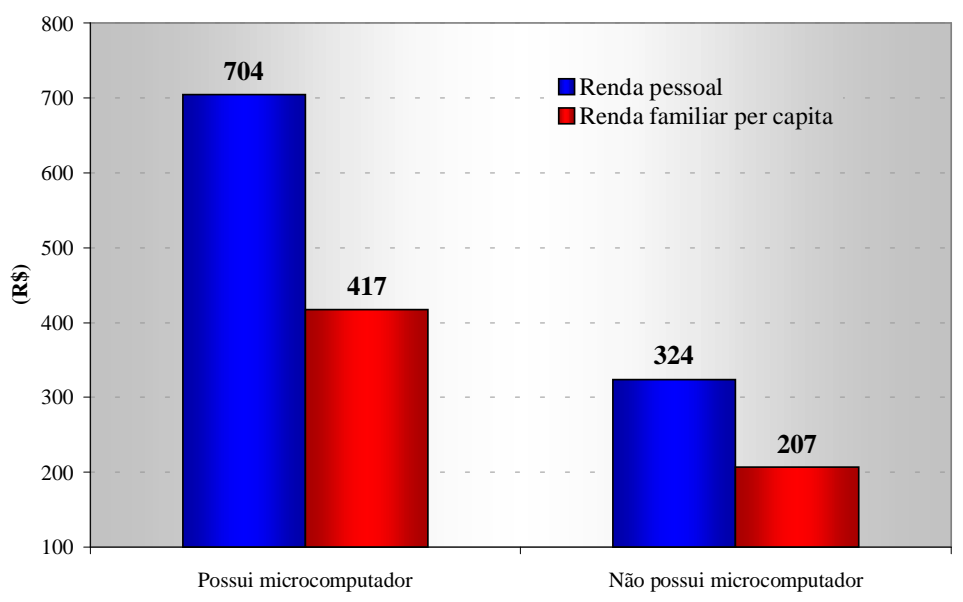


Gráfico 2.2.2: Percentual de pessoas que possuem computador no domicílio, por

faixa de anos de estudo, nas favelas do município do Rio de Janeiro

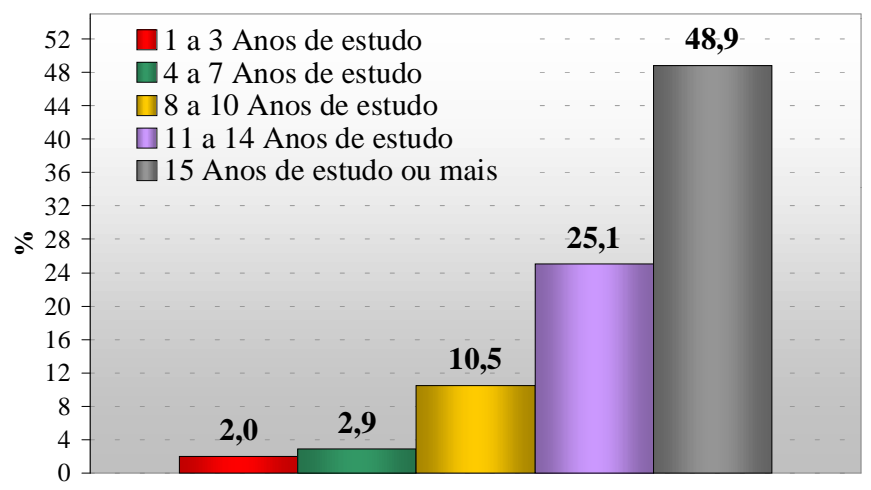

Os dados indicam uma clara correlação entre posse de computador e renda: os que possuem computador tem uma renda média, tanto individual como familiar, superior ao dobro da renda dos que não possuem. O fator educação tem, porém, uma incidência ainda maior: enquanto no grupo com 1 a 3 anos de estudos encontramos 2 computadores cada 100 domicílios, na faixa de pessoas com mais de 15 anos de estudo a posse do computador chega a 48.9 cada 100 domicílios.

Sem dúvida, há uma correlação entre renda e anos de estudo, mas a posse de computador entre os grupos com maior escolaridade, em relação aos de menor escolaridade, apresenta um diferencial de 25 a 1, enquanto o diferencial de renda entre estes grupos não chega a ser de 4 a 1.

Gráfico 2.2.3: Renda familiar per capita, por faixa de anos de estudo, nas comunidades do município do Rio de Janeiro

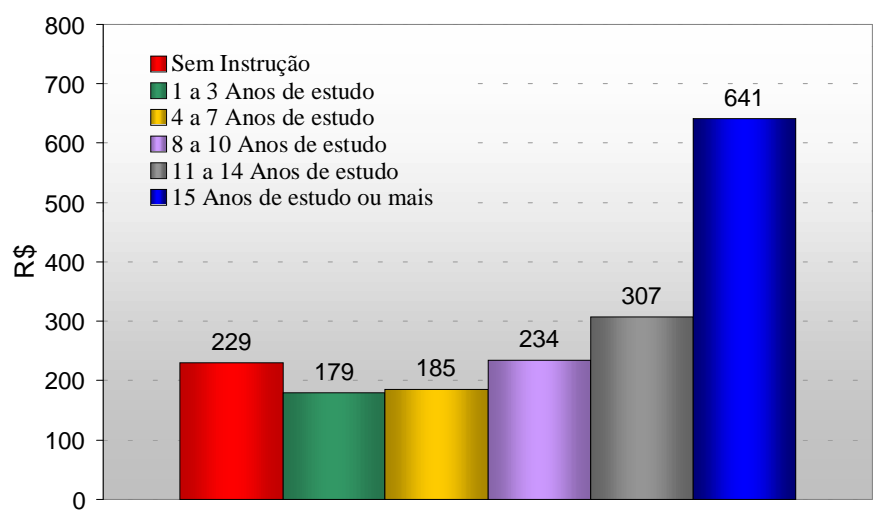

Nota: Em relação ao gráfico 2.2.3, que indica uma renda superior dos "sem instrução" em relação ao grupo de "1 a 7 anos de estudo", a explicação encontra-se 
Como mostra o gráfico 2.2.4, abaixo, enquanto o percentual de pessoas brancas que tem computador supera a média $(9.0 \%)$, e os pardos a igualam, a população negra apresenta um nível de posse equivalente à metade da média.

\section{Gráfico 2.2.4: Percentual de pessoas que possui computador em seu domicílio}

por cor/raça, nas comunidades do município do Rio de Janeiro

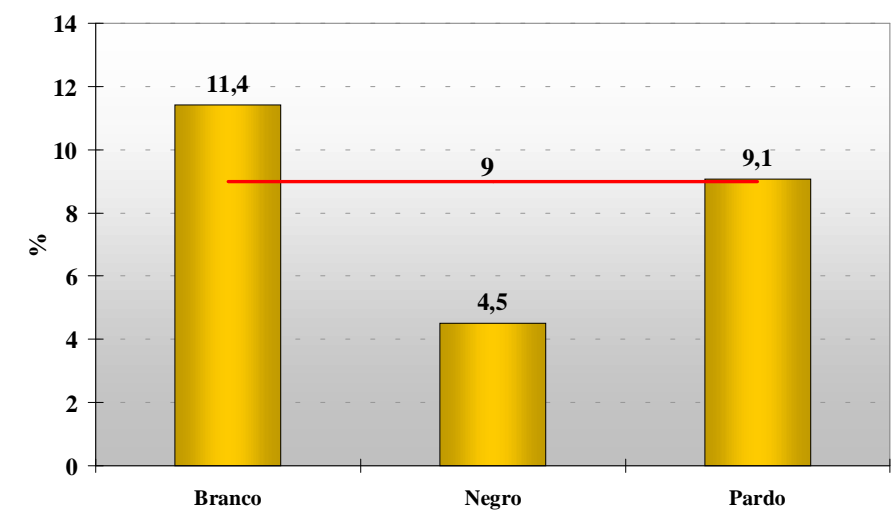

Nota: Os percentuais foram calculados em relação ao próprio grupo.

Como indica o gráfico 2.2.5, esta situação reflete a posição duplamente desfavorecida da população negra em termos de renda e educação:

Gráfico 2.2.5: Comparação das médias de renda familiar percápita e anos de estudo

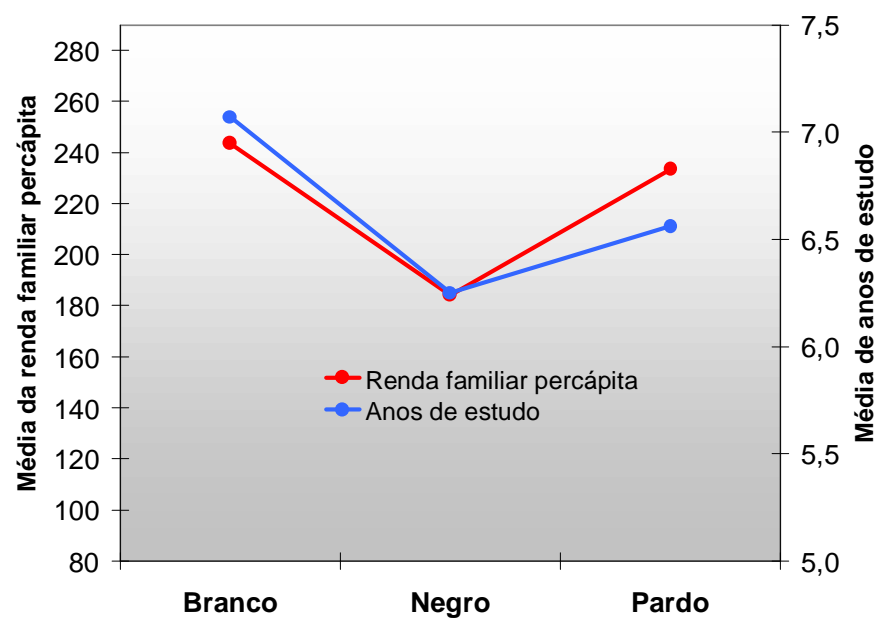




\section{3 - Posse, propriedade e uso}

Quando se analisam as relações entre posse e uso de computador, observa-se uma questão sociológica importante: como o computador é visto? Como um bem de consumo familiar - como refrigerador, telefone fixo, TV - e em sua propriedade e uso, é percebido como um bem de consumo coletivo? Como um bem de consumo individual como o carro ou, cada vez mais, o toca-fitas - em que a propriedade, a posse e o uso são considerados pessoais? Como indicam as respostas nos grupos focais, o computador geralmente é visto como um bem de consumo pessoal, embora posse e propriedade não fiquem claramente definidas. Muitos, em particular os jovens, definem o computador como "seus", embora tenham sido comprados pelos pais. A questão da posse está associada diretamente à utilização, pois, em geral, o usuário quem define o computador como seu. A tendência a se individualizar a propriedade do micro está associada tanto ao fato de que muitos membros da família não usam computador como à vontade de afirmar a posse, dado o conflito sobre os horários de sua utilização, tema que foi indicado nos grupos focais como causa de tensões na família.

\section{Uso de computador no domicílio}

A maioria dos participantes dos grupos focais que possuíam computador indicaram que o utilizam de forma exclusiva. Em alguns casos, o computador pertence a mais de uma pessoa, como filhos, cônjuge, irmão ou outro parente próximo. Os filhos normalmente utilizam esse equipamento para trabalhos escolares. É comum, entre os que o dividem com outra pessoa, haver problemas para conciliar o horário de utilização.

\section{4 - Usuários de Computador}

O número de usuários de computador nas favelas é o dobro daqueles que possuem: 
Gráfico 2.4.1: Percentual de pessoas que possuem e que utilizam microcomputadores nas comunidades de baixa renda do município do Rio de Janeiro

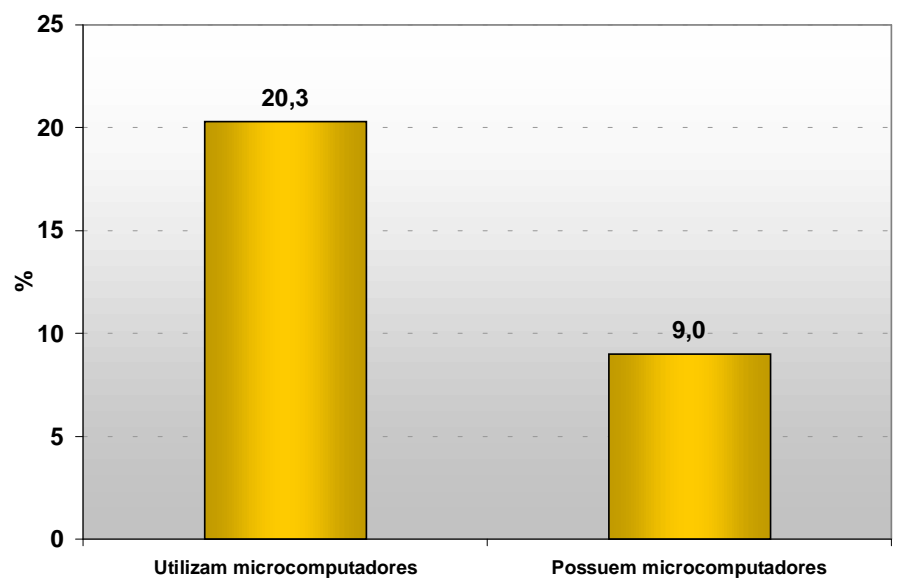

Uma possível explicação para o número de usuários de computador ser maior do que o de computadores por domicílio é que cada micro seria utilizado por vários membros da família. Mas trata-se de explicação insuficiente, pois somente $27.6 \%$ dos entrevistados indicaram o domicílio como principal local de uso do computador. O número superior de usuários em relação ao de proprietários deve-se principalmente ao fato de, o acesso nas favelas, o domicílio nao ser principal local de acesso ao computador:

Gráfico 2.4.2: Principal local de utilização do microcomputador nas comunidades de baixa renda do município do Rio de Janeiro

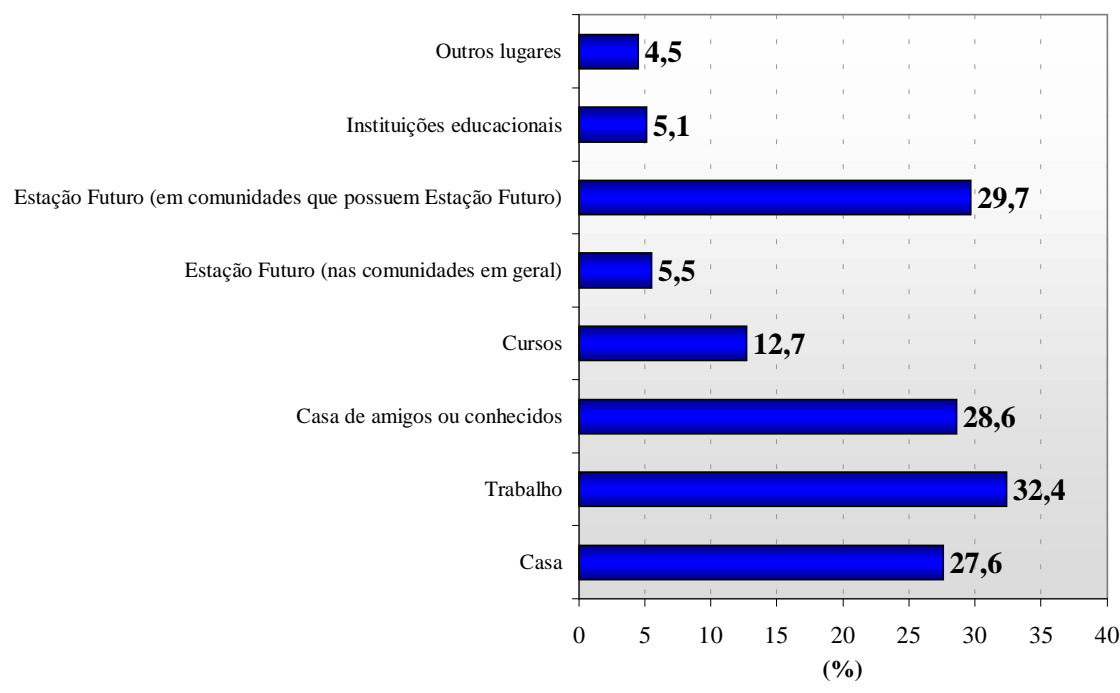


O trabalho, e não o domicílio, representa para os habitantes da favela o principal local de utilização de computador, seguido por casa de amigos ou conhecidos, ficando o domicílio em terceiro lugar. Nas favelas onde existem Estações Futuro (telecentros) da ONG Viva Rio, elas são o segundo local de acesso para quase $30 \%$ dos usuários de informática. Estes dados contradizem a expectativa de que, nos setores mais pobres da população, o número de usuários por computador no domicílio é alto, pois, em geral, são poucos os membros da família que utilizam computador, geralmente dependentes e menores de idade.

A baixa utilização de computador por domicílio se confirma no próximo gráfico, que indica: mais de um terço dos moradores não utiliza o computador, e somente $31,4 \%$ o utilizam com certa freqüência.

Gráfico 2.4.3: Freqüência de utilização de micro nas comunidades do município do Rio de Janeiro

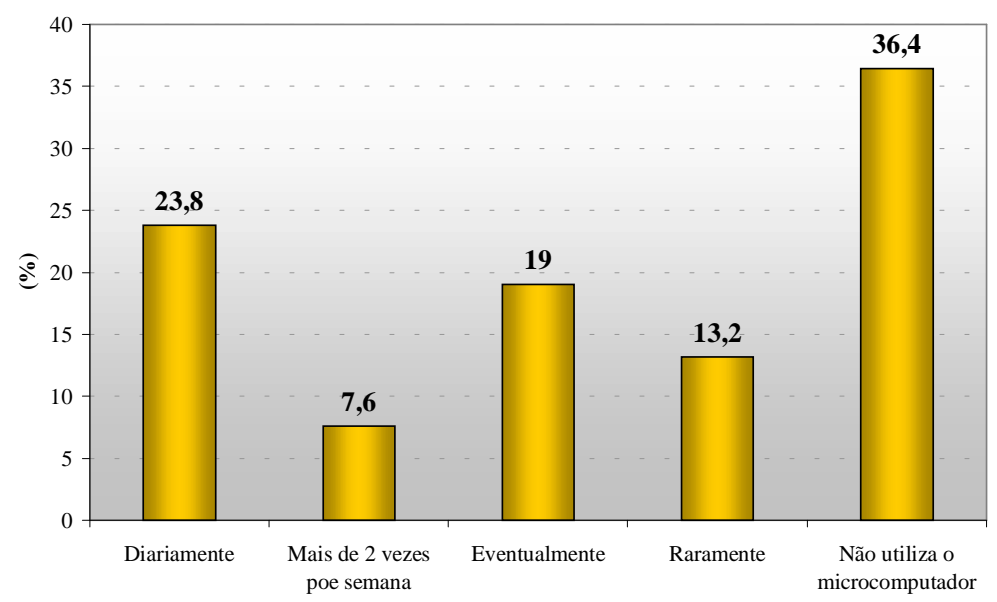

Universo: Quem possui micro no domicílio ( $9 \%$ da população).

Entre os usuários de computador (dentro ou fora do domicílio) o padrão que associa renda e educação com uso de informática se mantém, mas a distância tende a diminuir, o que indica que as pessoas de menor renda e escolaridade encontram em computadores fora do domicílio um mecanismo de igualação social. 
Gráfico 2.4.4: Percentual de pessoas que utilizam microcomputador por faixa de anos de estudo, nas comunidades do município do Rio de Janeiro

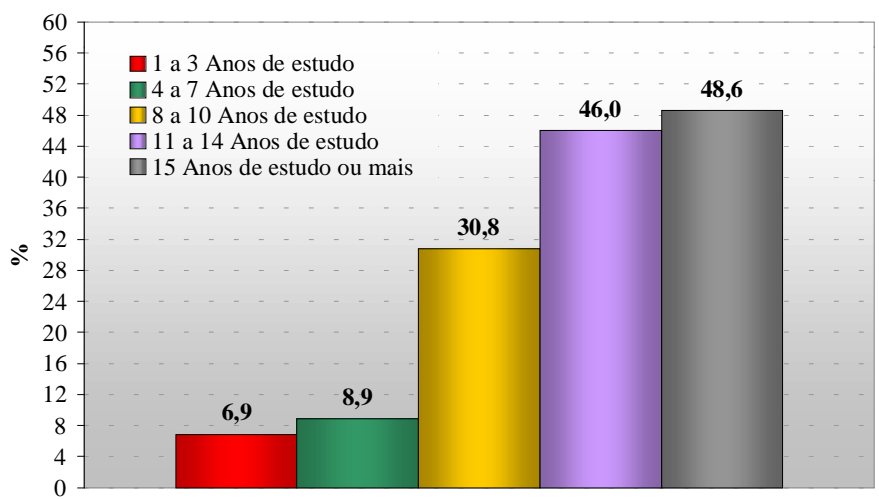

Nota: Os percentuais foram calculados em relação ao próprio grupo.

\begin{abstract}
Não-Usuários
Os jovens não-usuários de Internet acreditam que, para as pessoas que trabalham como autônomas, é mais difícil ter contato com computador. Isso porque seria necessário que o trabalhador autônomo tivesse seu próprio equipamento, enquanto a pessoa que está empregada com carteira assinada teria maior possibilidade de utilizar o micro na empresa.

Para as lideranças comunitárias (professores de ONGs, coordenadores de instituições comunitárias, presidentes de associações de moradores), a renda foi citada como fator determinante para a aquisição do equipamento. As pessoas com renda fixa conseguem juntar dinheiro ou comprovar a renda para adquirir um computador. Outro aspecto apontado se relacionaria à função que a pessoa exerce, ao tipo de trabalho. Aquele que vende bala no ônibus provavelmente terá menos chance de ter contato com um computador do que uma pessoa que trabalha em empresa, cujo cargo requer o uso do micro.

Segundo um dos jovens não-usuários da Internet, as pessoas jovens se interessam mais pelo computador do que as mais velhas. Mas o interesse do jovem estaria voltado para a diversão, o que incluiria jogos, lançamentos de filmes e esportes. As pessoas mais velhas utilizariam o micro mais o computador para trabalho.
\end{abstract}


Com relação à diferença entre homens e mulheres, no acesso ao computador, os jovens (não-usuários e na faixa de 16 a 22 anos) não acham que as mulheres fiquem excluídas, no tocante ao uso do computador e da informática, pois acreditam que esses instrumentos são acessíveis a todos, dependendo apenas do interesse de cada pessoa. No entanto, foi apontado por um dos jovens do grupo de não-usuários que os homens, por trabalharem em empresas, teriam mais facilidade de mexer no computador. As mulheres, como trabalham mais como recepcionista ou atendente, não teriam tanta oportunidade de manusear o micro.

Entretanto, nem todos concordam com a igualdade entre homens e mulherestodas, pois há uma questão cultural envolvida, que pode até vir a ser modificada. O presidente de uma associação de moradores aponta que, além do aspecto cultural, também existe o individual, que vai depender de cada pessoa e dos investimentos que ela se propõe a fazer.

Quando questionados acerca dos motivos para não terem acessado à Internet, um dos rapazes disse não querer se "viciar”, o que provavelmente aconteceria, já que teria acesso a um outro mundo e conheceria novas pessoas. Os outros afirmaram que nunca acessaram a Internet, por não terem computador.

Dois motivos alegados para a não-utilização de um ponto de acesso se referem à falta de dinheiro e ao desconhecimento sobre como proceder para navegar na Internet. Além disso, uma das meninas disse que não via razão para acessar, pois iria "ficar mexendo na Internet por nada”, pois não achava necessário. Outros participantes já acham que a Internet teria coisas a oferecer, como ajudar na procura de emprego e fornecer informações sobre concursos, além da possibilidade de conhecer pessoas e lugares. Um deles revelou que nem consegue imaginar o que a Internet poderia lhe trazer de benefício, dado seu completo desconhecimento sobre esta ferramenta.

Muitos reclamam da dificuldade para acessar, já que os cursos da comunidade não oferecem Internet. Uma delas disse que gostaria de ter mais conhecimento, pois seria mais fácil conseguir um emprego. O fato de não ter computador ou não acessar a Internet faz um dos rapazes se sentir um pouco constrangido, quando as pessoas começam a fazer algum tipo de comentário sobre informática. 
Segundo o grupo de lideranças comunitárias, não possuir computador acarreta exclusão de certos grupos. Uma das lideranças, professor em ONG, relatou que, quando ainda não tinha computador, ficava totalmente "por fora” das coisas que aconteciam, porque todos os professores se correspondiam via e-mail. Ele precisava pedir a algumas pessoas que enviassem e-mails por ele. Um coordenador de instituição comunitária também reclamou da exigência de que trabalhos e provas da faculdade que cursava fossem realizados no micro; não se considerava a possibilidade de a pessoa não possuir o equipamento.

\section{Freqüiência e usos de computador}

Com relação à freqüência de uso do computador, normalmente aqueles que o utilizam com maior constância são os que possuem o equipamento no domicílio e os que necessitam do micro para trabalho. O grupo de homens acima de 35 anos, da Maré, utiliza o micro constantemente. A maioria mexe no computador diariamente, ou pelo menos três vezes por semana. Os que o utilizam com menor freqüência têm dificuldade de acesso ao próprio equipamento. Dois rapazes, por exemplo, faziam uso diário do micro, no trabalho. No entanto, como eles não possuem computador no domicílio, a freqüência de uso diminuiu quando eles ficaram desempregados e passaram a depender de amigos para ter acesso ao computador.

Os jovens de até 16 anos e os homens de 22 a 35 anos, da Rocinha, também fazem uso freqüente do computador. A maioria o utiliza diariamente, e o restante mexe pelo menos uma vez por semana. Os jovens (até 16 anos) utilizam normalmente em casa e na escola, e os homens (22 a 35 anos) fazem uso do micro no trabalho e em casa. Casas de parentes ou de amigossão opções para os que não possuem acesso mais facilitado ao computador, assim como também a Estação Futuro.

De forma semelhante, a grande maioria de homens e mulheres de 16 a 22 anos, da Maré, faz uso diário do computador. Dois deles, inclusive, trabalham com computador. Outras duas pessoas, apesar de fazerem uso freqüente, não estão mexendo no micro em casa, pois, recentemente, o equipamento apresentou defeito. Apesar disso, a escola em que estudam permite o acesso ao laboratório e eles fazem uso constante do 
computador, na instituição. Entretanto, na escola o uso do computador e da Internet está limitado a pesquisas ou trabalhos acadêmicos

Ao contrário do que foi observado em relação aos jovens e homens, as mulheres acima de 35 anos (Rocinha) fazem pouco uso dos programas de computador, utilizando basicamente a Internet, e apenas quando necessário. Duas utilizam o computador com maior freqüência, devido a exigência no trabalho. A maioria faz uso eventual na Estação Futuro, ou em casa de parentes.

A utilização pelas mulheres de 22 a 35 anos (Rocinha) é ainda mais limitada do que a das mulheres mais velhas. O computador é usado em geral $1 \mathrm{vez}$ por semana, e apenas uma delas faz uso diário, devido a necessidade no trabalho. A maioria faz uso do computador na própria Estação Futuro, e até mesmo uma das participantes que tem micro em casa procura acessar a Internet na Estação, pelo custo menor.

Os não-usuários da Internet utilizam raramente o computador. A maioria fez uso do micro apenas em cursos básicos, e não o utiliza mais. Um deles utilizava no trabalho, mas atualmente está desempregado. Apenas dois rapazes utilizam o micro com maior freqüência, um em casa de parentes e o outro em loja, mas apenas para diversão (jogos).

Entre os líderes comunitários (professor de ONG, coordenadores de instituições comunitárias e presidente de associação de moradores), metade das pessoas utiliza diariamente o computador, em casa ou no trabalho, e os outros ou não utilizam ou o fazem apenas quando necessário para a instituição, indo normalmente à Estação Futuro.

De forma geral, os programas mais utilizados são Word, Excel, Power Point e Internet, objetivando, principalmente, a realização de trabalhos escolares $e$ profissionais (digitação de trabalhos, currículos, pesquisa escolar, busca de emprego). O Word é o programa mais utilizado por todos os grupos. Os não-usuários da Internet são os que mais utilizam jogos, seguidos pelos jovens de 16 a 22 anos e pelas mulheres acima de 35. Estas últimas utilizam bastante o computador, na elaboração de pesquisas escolares para os filhos. 


\section{5 - Faixa etária, gênero e raça}

Entre os usuários de informática na favela, como aliás no conjunto da população, existe uma tendência decrescente no uso da informática, à proporção que se avança na faixa de idade. Na favela, porém, essa tendência se acentua, devido aos níveis de escolaridade mais baixos entre os mais idosos, além de menores chances de no emprego:

\section{Gráfico 2.5.1: Percentual de utilização do microcomputador} segundo a faixa de idade

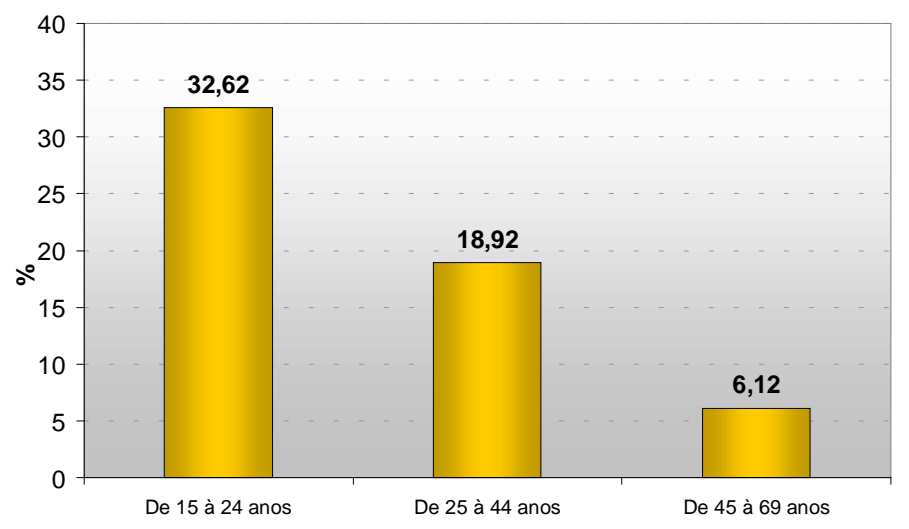

Nota: Os percentuais foram calculados em relação ao próprio grupo.

A população de usuários de informática é majoritariamente masculina:, sendoentre os homens cerca de um quarto do total; entre as mulheres não chega a um sexto: 
Gráfico 2.5.2: Utilização de microcomputadores segundo o sexo nas comunidades do município do Rio de Janeiro

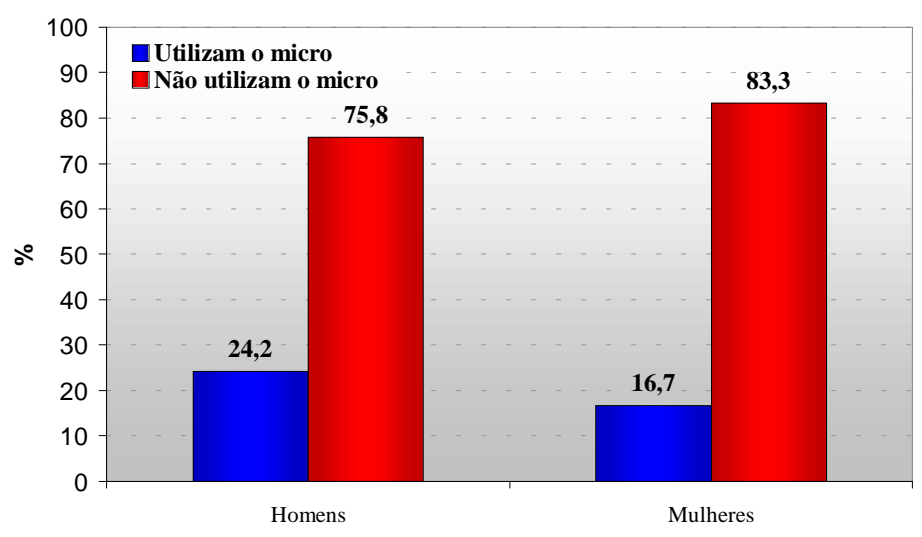

Se compararmos, entre os usuários da população negra, o número dos que usam computador com aqueles que têm posse, surpreende o fato de que a desigualdade detectada entre os proprietários tende a diminuir radicalmente:

Gráfico 2.5.3: Percentual de Utilização da Internet e posse de computadores, segundo cor/raça

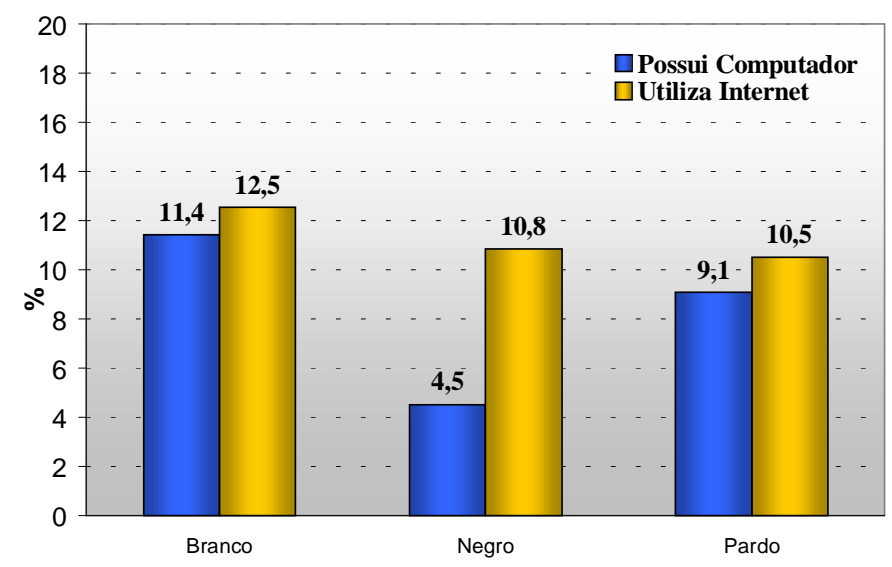

Nota: Os percentuais foram calculados em relação ao próprio grupo.

O que acontece em ambos os casos, ou seja, baixo acesso das mulheres e incremento do percentual da população negra de usuários? O trabalho atua como fator de exclusão digital no caso das mulheres, e de igualação social no caso dos negros. A maioria das mulheres trabalha em serviços de limpeza ou como empregadas domésticas, não tendo oportunidade de utilizar computador, enquanto um número maior de homens, inclusive muitos que trabalham como office boys, acabam convivendo em ambientes que incentivam, e por vezes permitem, o conhecimento de usos básicos do computador. 
Gráfico 2.5.4: Percentual de pessoas que trabalham, por sexo, entre os usuários de microcomputador

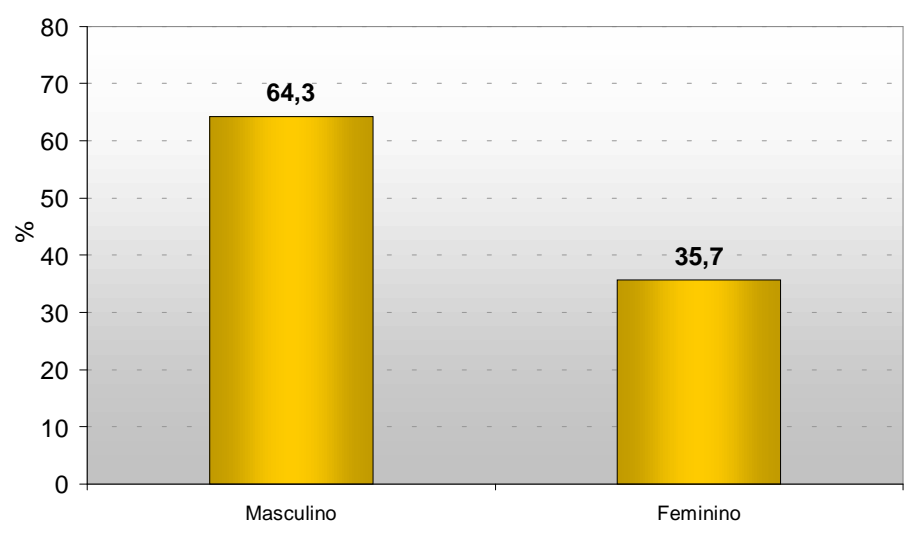

Universo: usuários do computador ( $20,3 \%$ da população).

Nas famílias de classe média, a socialização com o computador é um fenômeno quase natural, e as crianças, e mesmo os adultos, aprendem por osmose, no interior do núcleo familiar ou no trabalho. Não é este o caso das populações mais pobres, em que mais da metade, a maioria sem computador em casa, depende de cursos especializados e pagos:

Gráfico 2.5.5: Como usuários das comunidades do município do Rio de Janeiro aprenderam a usar o micro

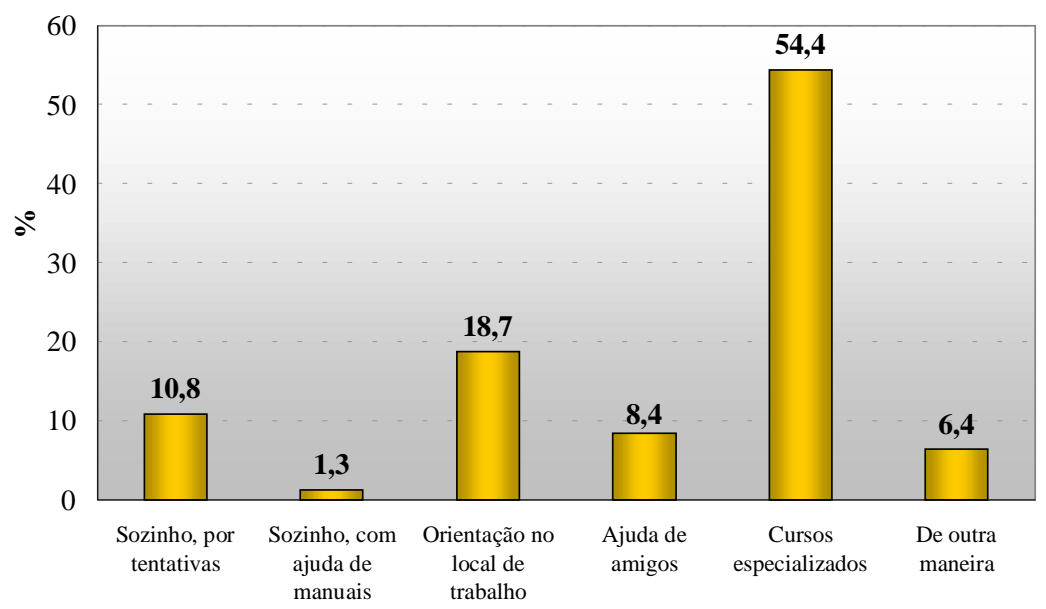

Universo: Usuários de microcomputador ( 20,3\% da população). 


\section{Apreendendo a usar o computador}

A maioria das pessoas aprendeu a mexer no computador em cursos realizados pelos moradores, e que abrangem, normalmente, apenas os aspectos mais elementares de uso do micro. Um número menor, porém expressivo, aprendeu no próprio trabalho, por exigência do cargo. Também é comum, mesmo entre aqueles que fizeram cursos, que a pessoa aprimore seu aprendizado, utilizando o computador sozinho, com orientação de alguém com mais experiência. Na verdade, normalmente não se observa uma forma única de aprendizagem, mas um conjunto de práticas que favorecem a utilização do computador.

O uso de manuais é muito raro, entre os entrevistados. Entre os homens acima de 35 anos, apenas um declarou ter aprendido sozinho, com a ajuda de manuais. Neste grupo, a aprendizagem ocorreu mais em cursos pagos e no trabalho. Um dos participantes do grupo foi jogar futebol na Alemanha, e lá era exigido que o atleta soubesse acessar a Internet, para tomar conhecimento a respeito de regras de futebol e do campeonato. Era fornecido suporte técnico e haviam professores que eram para ensinar o jogador a mexer no computador. Posteriormente, esse rapaz passou por experiência similar na Venezuela. Um outro exemplo pode ser encontrado no grupo de mulheres acima de 35: uma delas aprendeu a usar o micro quando trabalhou como recepcionista em uma clínica, cadastrando clientes, Contava com a orientação de uma colega de trabalho mais antiga.

\section{6 - Quem e quantos usam Internet}

Nas favelas, $11.6 \%$ da população maior de quinze anos usa a Internet. Assim, o número de usuários de Internet atinge cerca de metade do total de usuários de computador: 
Gráfico 2.6.1: Percentual de pessoas que utilizam microcomputadores e Internet, nas comunidades de baixa renda do município do Rio de Janeiro

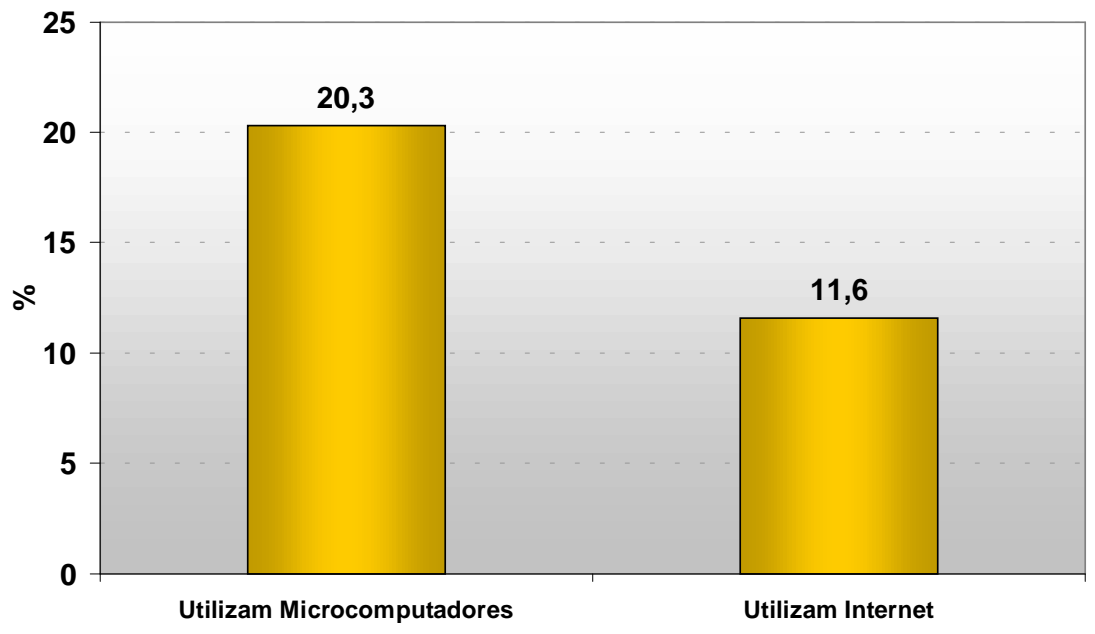

Do total dos possuidores de computador, somente um terço tem acesso à Internet, de forma que, do total de usuários de Internet, pouco mais de $25 \%$ o fazem a partir domicílio, reproduzindo os padrões de uso de computador mencionados acima, isto é, a principal fonte de acesso se encontra fora do domicílio.

Gráfico 2.6.2: Percentual de utilização da internet e microcomputador, nas comunidades do município do Rio de Janeiro

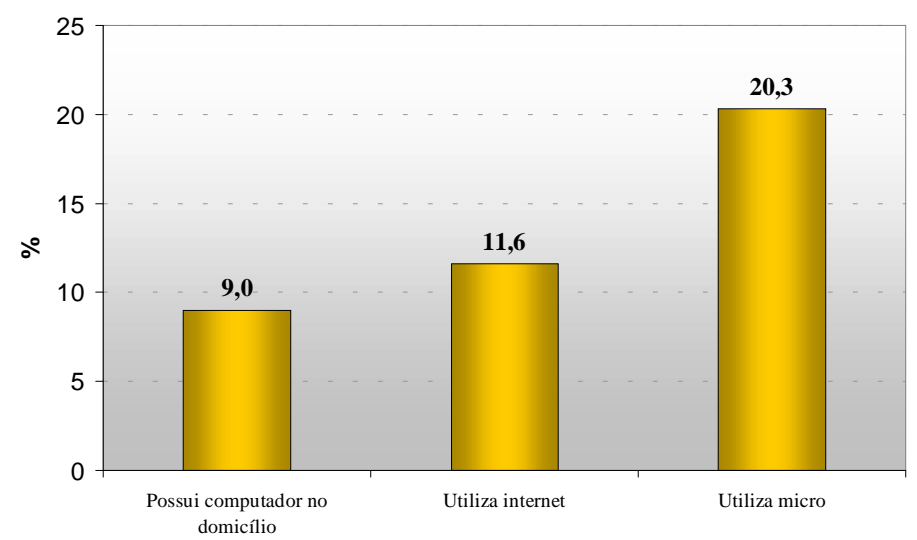


Praticamente todos os usuários que acessam a Internet do domicílio utilizam acesso discado de baixa velocidade, sendo que dois terços utilizam provedores gratuitos.

Gráfico 2.6.3: Tipo de provedor utilizado nas comunidades do município do Rio de Janeiro

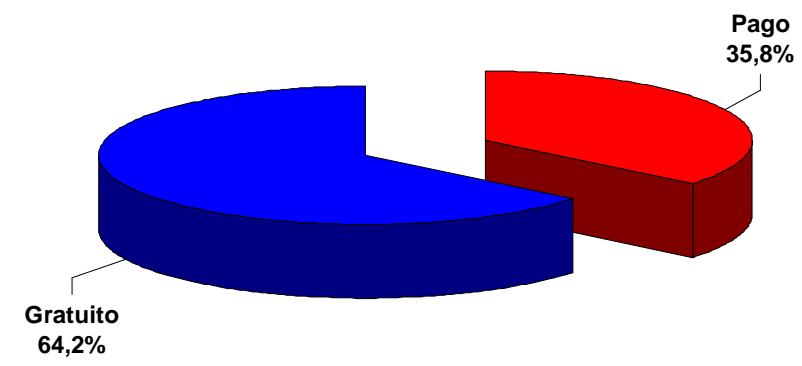

Universo: usuários da Internet ( 11,6\% da população).

O não-acesso à Internet rápida com um valor mensal fixo, independentemente do tempo de uso, tem uma dupla conseqüência: a informação demora mais tempo para ser acessada, enquanto o tempo disponível para permanecer na Internet é menor, já que o usuário paga pelo tempo em que permanece ligado.

Como mostra o gráfico a seguir, a intensidade do uso da Internet entre os habitantes das favelas ainda é bastante baixa. No estudo da exclusão digital, portanto, deve ser considerado não somente o número de usuários e não-usuários, mas também a intensidade do uso do micro, tanto na qualidade de acesso (baixa e alta velocidade) como o tempo efetivamente disponível. 


\section{Gráfico 2.6.4: Freqüência do acesso à Internet, nas comunidades do}

município do Rio de Janeiro

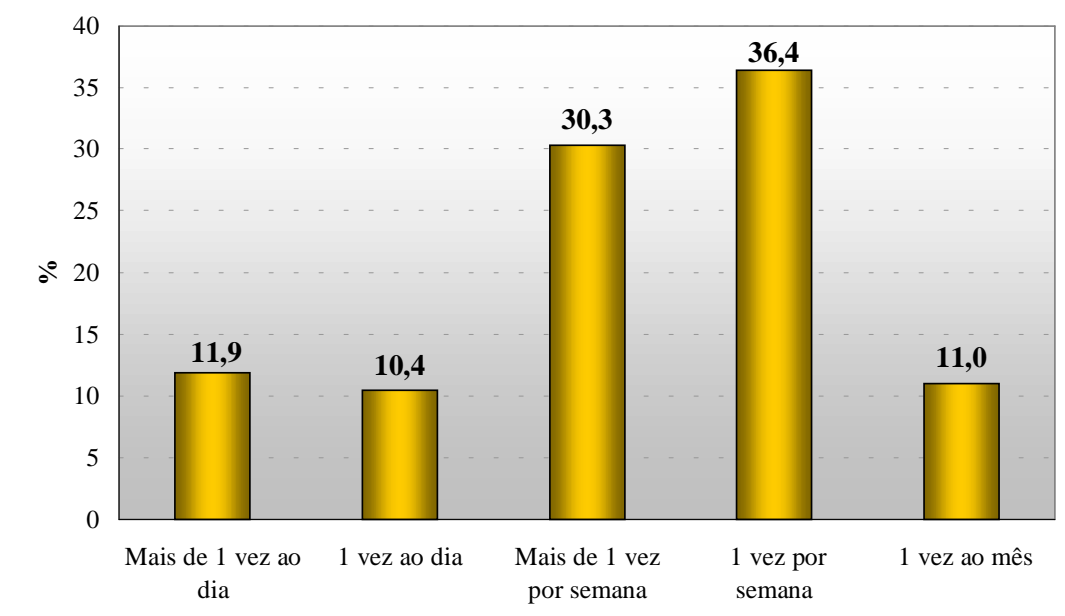

Universo: os que usam a internet (11,6\% da população).

No uso da Internet se repete, em linhas gerais, o fenômeno do uso do microcomputador. A maioria dos usuários acessa fora do domicílio, embora a importância do acesso no domicílio e em casa de amigos e de conhecidos apresente um ligeiro aumento, em particular no último caso:

Gráfico 2.6.5: Locais de acesso à Internet mais utilizados nas comunidades do município do Rio de Janeiro

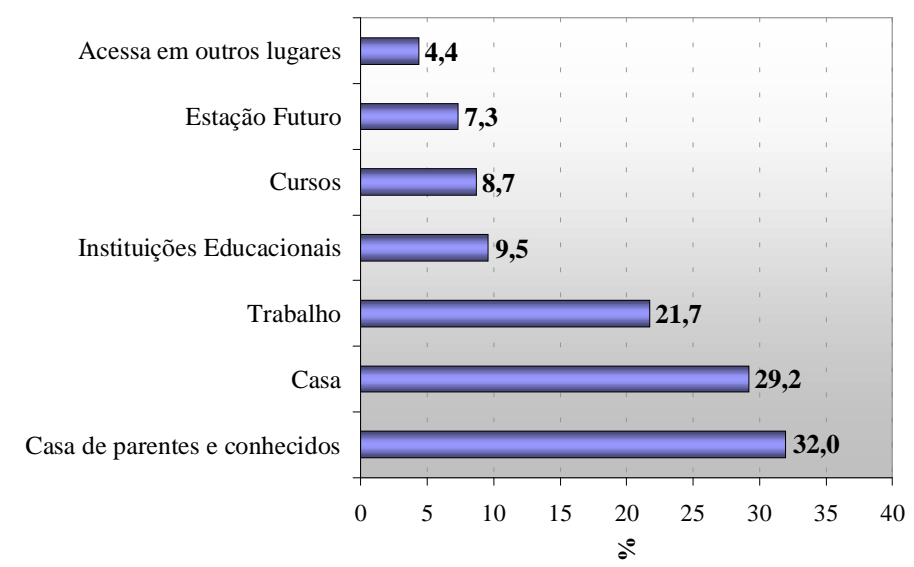

Universo: usuários da Internet ( 11,6\% da população).

No uso de Internet, a faixa etária ainda é mais decisiva do que no uso de micros, aumentando sua importância nos setores mais jovens: 


\section{Gráfico 2.6.6: Percentual de utilização da Internet e posse}

de computador, segundo idade

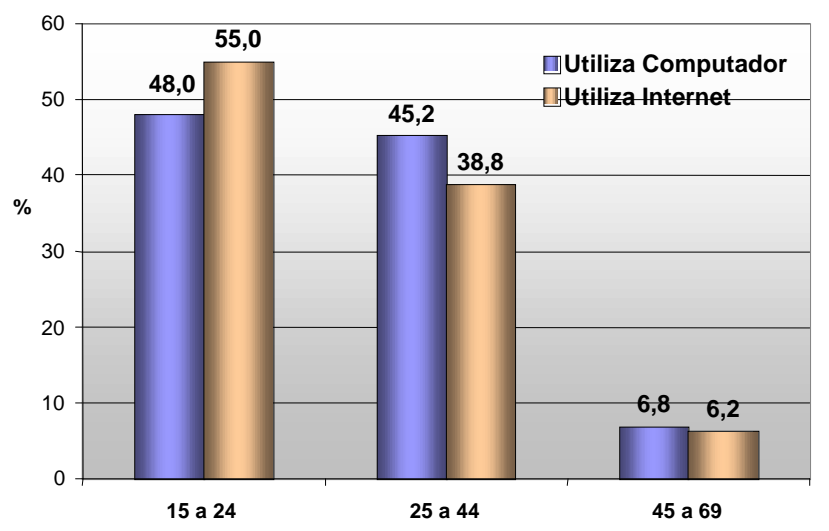

Nota: Os percentuais foram calculados em relação ao próprio grupo.

No uso de Internet se repete o padrão encontrado no uso de computador em relação à renda, e o mesmo efeito de exclusão em relação à população feminina:

Gráfico 2.6.7: Renda pessoal e familiar per capita média, segundo a utilização de Internet

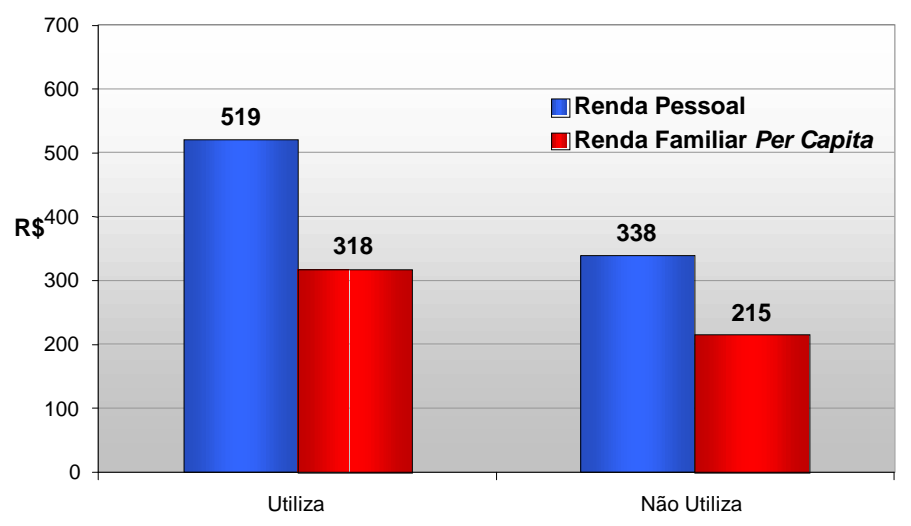




\section{Gráfico 2.6.8: Percentual de utilização da Internet e posse}

de computador, segundo sexo

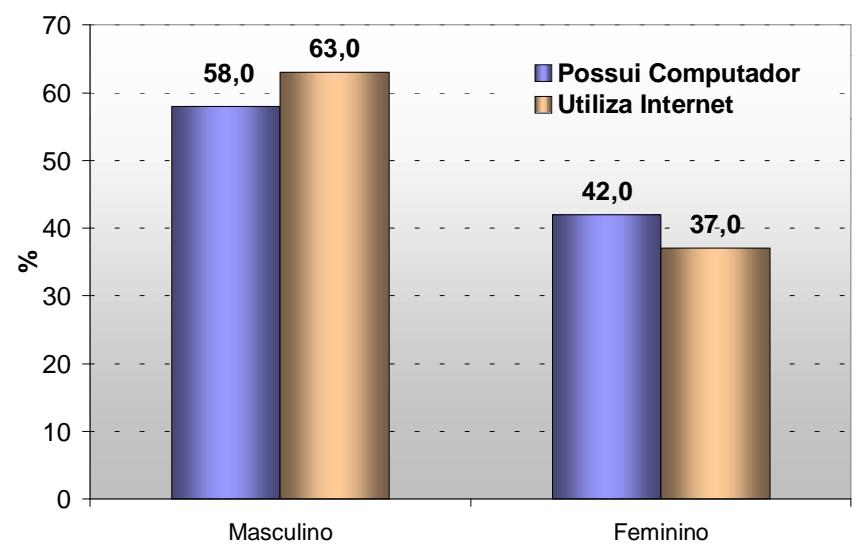

Nota: Os percentuais foram calculados em relação ao próprio grupo.

O fato que a distância entre usuários do gênero masculino e feminino aumenta conforme a idade confirma a hipótese que entre os adultos é o tipo de trabalho realizado um fator importante de exclusão digital.

Gráfico 2.6.9: Percentual de utilização de Internet, por sexo e faixa de idade

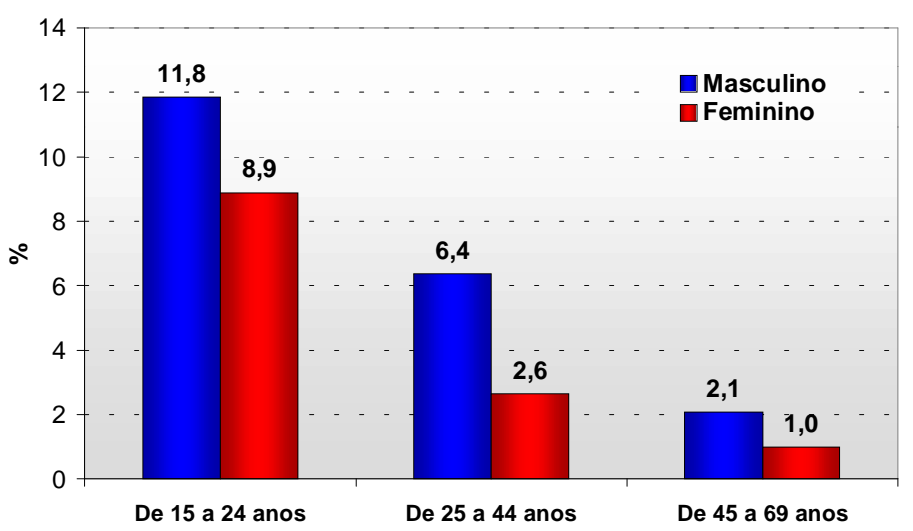

Da mesma forma queno uso de informática, o trabalho funciona como um nivelador social em relação à cor: 
Gráfico 2.6.10: Percentual de Utilização de Internet, e-mail e de posse de Computador, segundo Cor/Raça

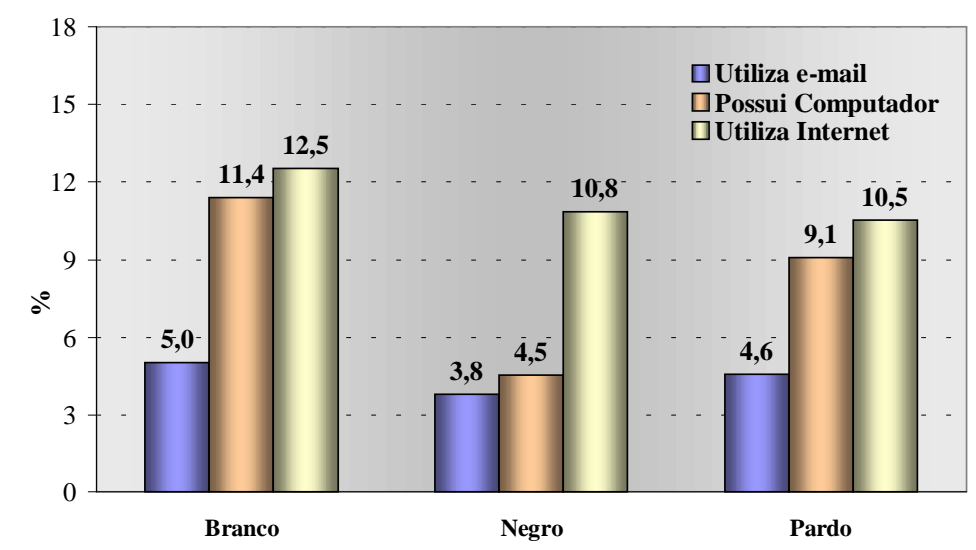

Nota: Os percentuais foram calculados em relação ao próprio grupo.

O maior acesso à Internet por nível de escolaridade se mantém,

Gráfico 2.6.11: Percentual de pessoas que utilizam a Internet por faixa de anos de estudo nas comunidades do município do Rio de Janeiro

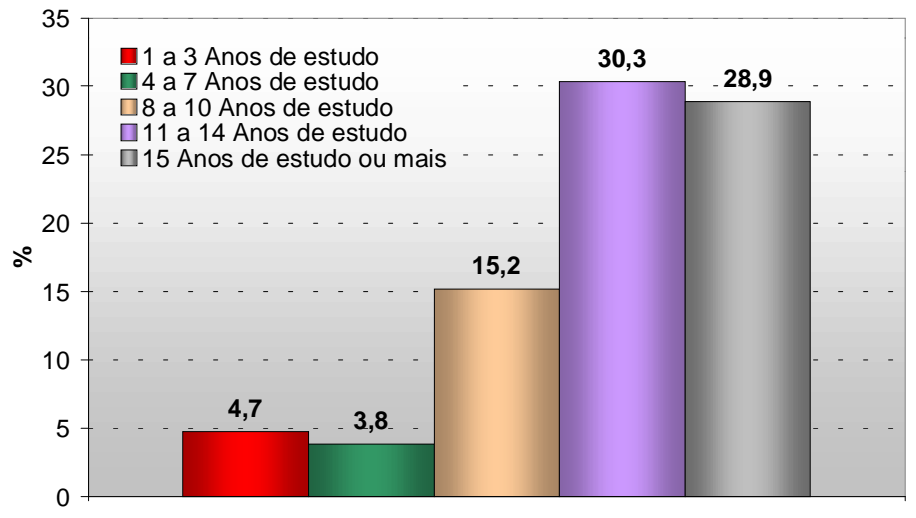

Nota: Os percentuais foram calculados em relação ao próprio grupo

A distância entre maior e menor renda aumenta visivelmente, quando se passa do grupo de usuários de computador para o de usuários de Internet, o que deve estar relacionado a seu custo e à dificuldade de acesso: 
Gráfico 2.6.12: Renda domiciliar per capita e renda pessoal, segundo o nível de inclusão digital

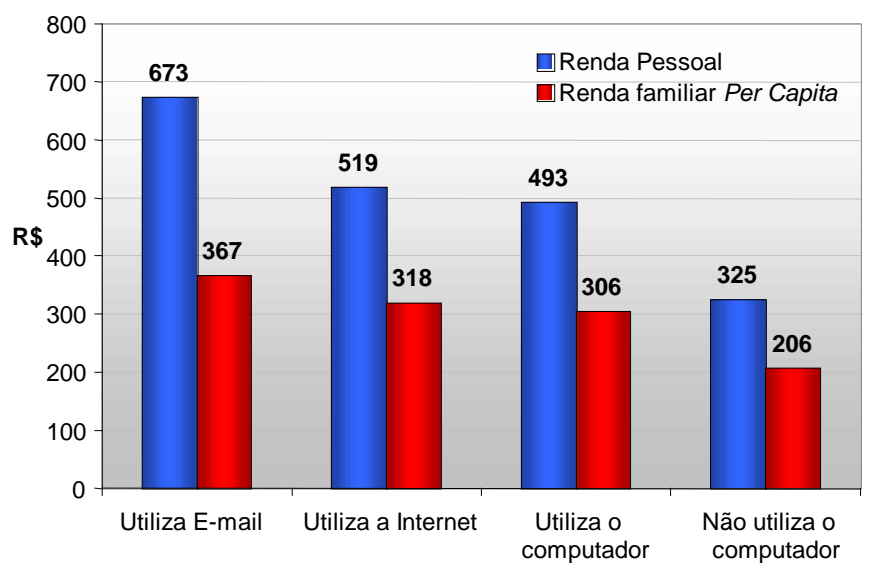

Tal hipótese é confirmada no gráfico a seguir, no qual se observa que, para mais de metade dos pesquisados, o motivo para não acessar a Internet é a falta de local, enquanto para $14.6 \%$ deles é o custo.

\section{Gráfico 2.6.13: Motivos para não acessar a Internet, nas comunidades} do município do Rio de Janeiro

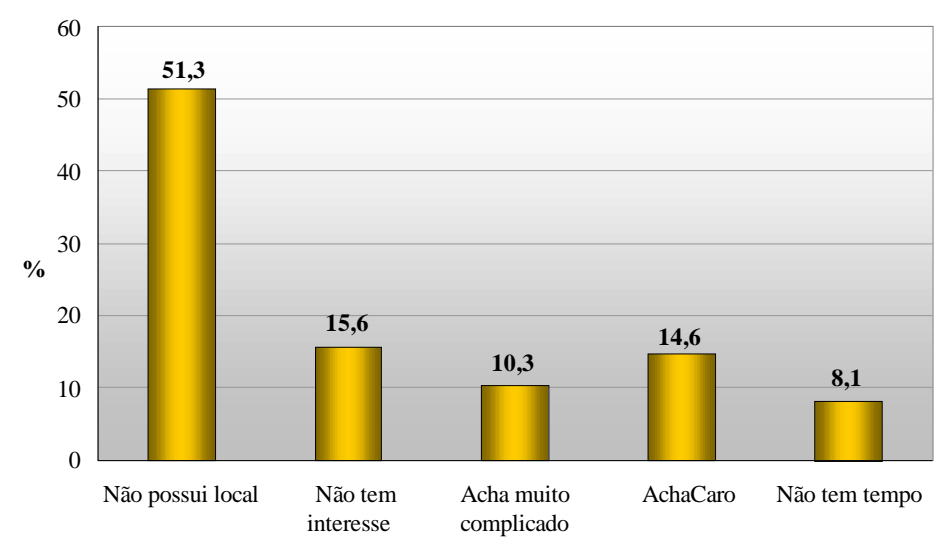

Universo: usuários de computador que não acessam a internet ( 8,7\% da população).

\section{Intensidade e tipos de uso}

A maioria dos participantes dos grupos focais utiliza a Internet pelo menos uma vez por semana, e fica conectada em torno de duas a três horas. Normalmente, o acesso é feito em casa, no trabalho ou na Estação Futuro. De forma geral, o grupo de homens acima 
de 35 anos e o grupo das lideranças comunitárias, principalmente alguns coordenadores de instituições comunitárias, são os que acessam com maior freqüência. Metade dos homens acima de 35 anos acessa a Internet no mínimo três vezes por semana, normalmente por causa do trabalho ou em busca de informação a ele relacionada como, por exemplo, IPVA, financiamento da Caixa Econômica ou cadastramento de CPF. Os que acessam com menor freqüência, normalmente o fazem rapidamente, para procurar alguma informação específica (sobre concurso ou consulta de saldo bancário, por exemplo).

Todas as lideranças comunitárias (professor de ONG e alguns coordenadores de instituições comunitárias) que têm acesso à Internet, utilizam-na diariamente. Alguns chegam a ficar conectados o dia inteiro. $O$ acesso à Internet está normalmente vinculado a trabalho, comunicação com parceiros, envio de projetos e documentos, divulgação de seminários e captação de recursos. Alguns acessam também para ler jornal ou para pesquisa de faculdade.

Os sites preferidos pelos jovens entre 16 e 22 anos estão basicamente vinculados à diversão, em especial os de música e de fofoca (Fuxico). Um dos jovens é vicepresidente do fã clube de Vanessa Jackson, e está sempre procurando saber tudo o que é divulgado sobre ela. Outro rapaz entra toda noite para se distrair, depois de passar o dia inteiro trabalhando com computador. Às vezes, envia relatórios a clientes, busca informação sobre economia, além de visitar salas de bate-papo, ICQ e sites com notícias e fofocas. A Internet também é utilizada por alguns desse grupo, e pela maioria dos jovens até 16 anos, para a realização de trabalhos escolares, através de pesquisa em sites de busca. Para os participantes em geral, os principais pontos que devem ser melhorados na Internet são velocidade, segurança, facilitação do acesso e custo. $O$ custo do acesso foi bastante enfatizado pelos homens acima de 35 anos. Para um deles, a propaganda deveria ser o financiador da Internet. $O$ usuário deveria pagar apenas o custo da eletricidade, e os patrocinadores pagariam o custo da Internet. Segundo ele, esta seria a forma mais racional para se globalizar realmente a Internet e diminuir o nível de exclusão. 
O grupo de jovens entre 16 e 22 anos se mostrou preocupado com o uso contínuo da Internet, já que tudo pode ser feito a partir do computador, desde pagamento de contas até encontros com amigos e diversão. Para eles, isto levaria a um isolamento, um distanciamento entre as pessoas, pois a Internet é muito impessoal. O grupo de lideranças comunitárias também acha que o computador gera um certo isolamento: as pessoas ficam presas ao micro ou à Internet, e se esquecem de conversar. O professor que atua em uma ONG comparou o computador à televisão: as pessoas ficam presas a um programa, em determinada hora. Embora a Internet também traga a possibilidade de interação, trata-se de uma relação fria, porque não há um contato pessoal.

\section{Tipos de sites e conteúdos acessados}

A qualidade da conexão e a necessidade de tradução para os sites estrangeiros foram indicados pelas mulheres entre 22 e 35 anos como aspectos importantes a serem melhorados. De maneira geral, os jovens de 16 anos não esperam mais nada da Internet, apenas melhor organização. O excesso de propaganda também incomoda este grupo.

No que diz respeito aos sites estrangeiros, poucos são os que acessam sites em outras línguas. Aqueles que procuram este tipo de site normalmente o fazem por causa de curso de línguas, ou mesmo de trabalho profissional. Um jovem de 16 a 22 acessa sites em inglês por uma demanda do curso, e dá preferência àqueles de música, fofocas e notícias. Ele não tem dificuldades com a língua. Um homem acima de 35 anos acessa um site $\mathrm{BBC}$ cuja proposta é ensinar inglês, o que torna o conteúdo mais compreensível.

No grupo de homens na faixa dos 22 a 35 anos, um deles já acessou sites gays em cantonês, tailandês, chinês. Ele não procura o site pelo conteúdo, que inclusive não compreende, mas pelas imagens, pois trabalha com desenho e webdesigner. Outro, que trabalha com esportes, acessou algumas vezes um site da Inglaterra sobre futebol $e$ conseguiu compreender o conteúdo, com a ajuda do tradutor de texto.

Poucas mulheres entre 22 e 35 anos e acima dos 35 acessam sites em outras línguas. As que o fazem não têm dificuldade com o conteúdo, pois já freqüentaram cursos. Alguns dos jovens acessam sites de bandas de música e procuram ler a história da banda, 
quando há tradução. Do contrário, eles não se preocupam com o texto, e tentam entender o conteúdo do site pelas imagens.

Todos os participantes gostariam de ter contato com comunidades de outros países. A maioria gostaria de conhecer algo sobre a cultura, os costumes e as crenças de outros povos. Um dos jovens entre 16 e 22 anos se interessa especificamente pela cultura negra dos Estados Unidos, no que tange ao tipo de música. Já para os rapazes de até 16 anos, o assunto seria mulher. A possibilidade de divulgação do seu trabalho em português seria muito interessante para um dos homens acima de 35 anos, que é músico.

A maioria das pessoas também achou interessante a idéia de conhecer comunidades carentes de outros países, e ter acesso a seu modo de vida. Foi enfatizada a troca de informações, com o objetivo de melhorar a vida nas comunidades, a partir de experiências em que alguma dificuldade tenha sido superada, e o sofrimento das pessoas, minimizado. Outros sugeriram apenas uma comparação entre modos de vida. Uma das mulheres de 22 a 35 anos gostaria de ver a diferença entre uma favela de Primeiro Mundo e outra, de Terceiro Mundo.

Alguns dos participantes relataram haver conhecido pessoas pela Internet, com exceção do grupo de mulheres acima de 35 anos. Dois dos jovens de 16 a 22 anos fizeram várias amizades em salas de bate-papo e, inclusive, já namoraram moças que conheceram na Internet. No entanto, um deles declarou achar perigoso marcar encontros através de salas de bate-papo e evita dar informações sobre sua vida para pessoas que não conhece.

No grupo de homens acima de 35 anos, um deles organizou alguns encontros de vários internautas, no Norte Shopping, e ainda mantém contato com eles, por e-mail e por telefone. Essas pessoas estão sempre trocando informações, e ele ajudou a empregar dois deles na área de segurança. Outro participante do grupo fez amizade com um argentino numa sala de bate-papo, mas não chegou a conhecê-lo pessoalmente.

Algumas mulheres entre 22 e 35 anos relataram haver conhecido homens pela Internet, chegando a encontrá-los pessoalmente. Uma delas colocou seu perfil num site, e conheceu muitas pessoas, chegando a ir a encontros marcados pelos internautas. Um 
deles conheceu chegou a consertar seu computador, e outro, que era advogado, ajudou em sua separação. No grupo de homens de 22 a 35 anos, um deles conheceu uma moça de Minas Gerais numa sala de bate-papo. Eles namoraram por quase dois anos, mas acabaram se separando quando ela propôs casamento. Ela o ajudou a localizar a família de seu pai, com a qual ele havia perdido contato há muitos anos, conseguindo encontrar uma de suas tias.

A maioria dos jovens até 16 anos acessa salas de bate-papo. Eles disseram já haver conhecido pessoas com as quais eles conversam no chat, enviam e-mails ou falam por telefone. No entanto, nenhum deles demonstrou interesse em conhecer esses internautas pessoalmente.

Segundo as lideranças comunitárias, faltam mecanismos de controle quanto ao conteúdo dos sites, para impedir o acesso a páginas que, por exemplo, estimulem a violência. Por outro lado, uma das coordenadoras de instituição comunitária acredita que, se tivesse acesso à Internet, poderia ajudar pessoas da comunidade, através da divulgação de situações que dependem da solidariedade das pessoas.

Segundo um dos homens com mais de 35 anos, o interesse das pessoas está na informação, na comunicação e na educação, e a Internet oferece um mundo a ser explorado. As pessoas, quando conhecem a Internet, se deparam com uma nova situação, que abre portas para tudo. Para as mulheres acima de 35 anos, a Internet está cada vez mais presente no dia-a-dia das pessoas. Quem não sabe mexer no computador vai ter dificuldade para sacar dinheiro no banco. Atualmente, há uma grande diversidade de assuntos que são tratados via Internet, como inscrições em concurso, renovação de matrículas de alunos de escolas estaduais, e até um programa convencional de TV fornece receitas que podem ser visualizadas em sites.

No grupo de lideranças comunitárias, algumas relações institucionais e parcerias foram formadas a partir da Internet. O professor da ONG conseguiu contato com o cônsul da Austrália através da Internet, e enviou uma parte do material do projeto para avaliação. Foi observado pelos participantes deste grupo que outras instituições, localizadas fora da comunidade, respondem mais rapidamente através de e-mail do que por contato telefônico. Mesmo que a resposta seja negativa, é mais difícil não haver um retorno, o que é comum por telefone. Portanto, a instituição que tem acesso à Internet é 
mais valorizada, além de a comunicação ser mais ágil. Mais do que isso, a Internet abre portas antes impensadas, proporcionando uma gama maior de possibilidades, até mesmo a formação de parcerias com internautas de outros países

Normalmente as mulheres acima de 35 anos acessam a Internet apenas quando necessário, para fazer pesquisa escolar para os filhos ou obter informações sobre empregos e concursos. Uma das que a utilizam diariamente, acessa no emprego apenas sites relacionados a trabalho, nunca a diversão. Ela utiliza a Internet para compra de livros para a creche ou para a escola, verificando formas de pagamento e conteúdo desses livros. Tem muita vontade de navegar livremente e entrar em salas de bate-papo, mas isso não é permitido em seu ambiente de trabalho.

A maioria dos homens de 22 a 35 anos utiliza a Internet basicamente para verificar emails. Outros procuram sites de diversão, tais como de esportes, música ou filmes. Um deles acessa a Justiça Federal para acompanhar um processo.

O custo da Internet é citado pelos grupos de mulheres e de homens de 22 a 35 anos como fator que limita a freqüência de acesso, e também o tempo da conexão. A mãe de um dos jovens entre 16 e 22 anos controla o uso da Internet e do computador por causa dos gastos envolvidos. Ele acessa a Internet durante a madrugada para baratear o custo, utilizando o ICQ ou sala de bate-papo com os amigos.

Para alguns participantes dos grupos focais, a Internet é uma ferramenta importante para seu trabalho. A maioria dos homens com mais de 35 anos utiliza a Internet para o trabalho. Um deles trabalha com futebol, no clube Botafogo, e acessa a Internet em busca de informações sobre o esporte. Para outro, a Internet é um instrumento fundamental de divulgação de seu trabalho nos meios de comunicação. Isto lhe permite conseguir $80 \%$ de seu sustento. Ele está promovendo um evento em que será enterrado vivo. Através da Internet, ele também conseguiu uma entrevista com o Wagner Montes e contato com o diretor do Banco do Brasil, que vai lhe oferecer suporte para uma viagem ao exterior, além de homologar o recorde nacional de tempo enterrado.

Uma das mulheres acima de 35 anos vendia vídeos e livros pela Internet. Ela possuía um cadastro de e-mails, em que eram anexadas as propagandas a serem enviadas. Outra também ganhava dinheiro com a Internet, trabalhando com serviços gráficos. 
Algumas pessoas pagavam uma taxa mensal para que ela verificasse seus e-mails, pois elas não tinham tempo para isso. Entre as mulheres na faixa de 22 a 35 anos, uma teve que aprender a utilizar a Internet por exigência do trabalho, já que era necessário o acesso a sites específicos, da Receita Federal e da Caixa Econômica. Também no grupo de homens de 22 a 35 anos, o técnico de futebol fez uma parceria com uma ONG da Itália, da qual várias famílias na Rocinha vão receber ajuda de custo para que seus filhos possam participar do time.

O provedor utilizado pelos que têm computador em casa normalmente é gratuito, (IBEST ou IG, na maioria das vezes). Apenas no grupo de jovens de até 16 anos, metade deles utiliza provedor pago.

Os sites que as mulheres de 22 a 35 anos mais acessam são aqueles voltados para emprego (CAT) ou concursos. Uma delas teve retorno, e foi chamada para participar da seleção para uma vaga de auxiliar contábil. No entanto, ela recusou pois estava realizando um trabalho como autônoma, que pagava melhor. As mulheres acima de 35 anos também costumam enviar currículos e fazer inscrições em concursos pela Internet.

Apenas um dos jovens de 16 a 22 anos já procurou emprego através da Internet. Ele é cadastrado no SIEA (Site de Imigração do Ambiente Escola), está constantemente verificando possibilidades de estágio, e já conseguiu um trabalho através deste site.

Uma das pessoas do grupo de lideranças comunitárias também já procurou emprego pela Internet. Ela passou pelo processo de seleção da Vale do Rio Doce, fazendo várias entrevistas. No final, não foi chamada e teve a impressão de que eles estavam apenas formando um banco de dados.

\section{Melhorias na Internet}

De maneira geral, os participantes indicaram como principais pontos a serem melhorados na Internet: velocidade, segurança, facilitação do acesso e custo. O custo do acesso foi bastante enfatizado pelos homens acima de 35 anos. Para um deles, a propaganda deveria ser o financiador da Internet. $O$ usuário deveria pagar apenas o custo da eletricidade e os patrocinadores pagariam o custo da Internet. Segundo ele, 
esta seria a forma mais racional para se globalizar realmente a Internet e acabar um pouco com a exclusão.

O grupo de jovens de 16 a 22 anos se mostraram preocupados com o uso contínuo da Internet, no qual tudo seria feito a partir do computador, desde pagamento de contas até encontros com amigos e diversão. Para eles, isto levaria a um isolamento, um distanciamento entre as pessoas, pois a Internet é muito impessoal. O grupo de lideranças comunitárias também acha que o computador leva a um certo isolamento daqueles que o utilizam. As pessoas ficam presas ao micro ou a Internet, esquecendo de conversar. O professor da ONG comparou o computador a televisão, pois as pessoas ficam presas a determinado programa naquela determinada hora. No entanto, a Internet traz a possibilidade de interação, mas é uma relação fria porque não há um contato pessoal.

A qualidade da conexão e a necessidade de tradução para os sites estrangeiros também foram indicados pelas mulheres entre 22 e 35 anos como aspectos importantes a serem melhorados.

A maioria concorda que o ideal seria que todos tivessem condições de ter um computador e acesso a Internet. A Internet também tem o papel de educador pois favorece o acesso à informação e a educação.

\section{Computação, educação e cursos pela Internet}

Os pais dos jovens do grupo de 16 a 22 anos demonstram preferir que os filhos fiquem em casa, utilizando o computador, e não na rua, sujeitos a toda sorte de situações, especialmente as relacionadas à violência. Um jovem do grupo de não-usuários da Internet também percebe essa atitude por parte de um tio, que facilita o acesso ao computador para evitar que ele fique nas ruas se metendo em confusão. Este estímulo ao uso do micro passa por uma tentativa de proteção e de dar maior segurança aos filhos. Apesar de reconhecerem isso, os jovens ressaltam a importância de manterem outras atividades e experiências, como contatos pessoais, além de trabalho, estudo e esporte. 
Alguns jovens de 16 a 22 anos também observam que os pais incentivam o uso do computador visando a abrir portas na vida profissional, para ajudá-los a conseguir um emprego melhor. Um jovem relata que o pai o estimula não só pelo lado profissional, mas também para que ele possa ajudá-lo com os aparelhos eletrônicos, que o pai não sabe manusear.

Ainda os jovens de 16 a 22 anos observaram que o computador também seria uma opção melhor que a televisão. Com a TV, a pessoa não pode interagir e se esquece do que existe a seu redor, afastando-se, inclusive, da leitura. Em contrapartida, o computador pelo menos permite que a pessoa treine a leitura e escrita.

Outras lideranças comunitárias, dentre as quais o presidente de uma associação de moradores, o professor da ONG e os coordenadores de instituições comunitárias, também acreditam que o computador pode ajudar a tirar o jovem da criminalidade. Entretanto, apenas isso não seria suficiente, devendo-se tomar outras iniciativas para que os jovens tenham para onde ir, depois de fazer o curso. Segundo essas lideranças, são necessários mais recursos e parcerias com outras escolas, com empresários e com a sociedade civil. Foi também observada a necessidade de investimento no ser humano, para gerar mudança. O foco deveria estar na educação e na geração de renda e de emprego. Foi ressaltada a importância de se cobrar do Estado, que tem responsabilidades para com essas pessoas. O papel das instituições não seria o de fazer o trabalho do Estado.

Quanto à possibilidade de utilização do computador nas escolas, ela fica limitada às de rede particular. Praticamente nenhum dos alunos de escolas públicas tem acesso ao computador na própria escola. Duas mulheres de 22 a 35 anos estudam em escola pública que possui computador para uso exclusivo dos funcionários; não há possibilidade de acesso para os alunos. No grupo de homens e mulheres até 16 anos, os alunos de escola particular têm acesso ao computador e, em alguns casos, também à Internet, mas com uso direcionado para pesquisa escolar. Alguns professores pedem aos alunos que façam pesquisa na Internet, mas em caráter opcional.

No grupo de jovens de 16 a 22 anos, uma das moças é estudante de faculdade particular e pode utilizar o computador e acessar a Internet no laboratório, que é aberto a todos os alunos. Eles podem, inclusive, acessar conteúdos pessoais, não 
vinculados à atividade acadêmica. Um dos rapazes da mesma faixa de idade está participando de um projeto para implementação de um laboratório para os alunos da escola estadual em que estuda. Isto foi possível devido a uma doação de computadores Pentium II, pela Petrobras. O laboratório já está praticamente pronto; ele e um colega darão aulas para os outros estudantes.

Quanto à realização de cursos pela Internet, a maioria dos homens acima de 35 anos se mostrou interessada, e a opinião das mulheres acima de 35 anos está bastante dividida. Já as mulheres entre 22 e 35 anos e os jovens de até 16 anos não fariam qualquer tipo de curso pela Internet.

A principal restrição dos grupos aos cursos via Internet diz respeito à necessidade de um professor para esclarecer dúvidas. Para um dos moradores acima de 35 anos, a interação com o professor é fundamental para o ensino, e mesmo que houvesse um serviço de apoio para sanar dúvidas, não substituiria o contato pessoal. Para as mulheres de 22 a 35 anos, a interação é essencial para que o aluno aprenda e tire suas dúvidas. Algumas mulheres acima de 35 anos acham que a Internet deixaria a pessoa isolada. Para elas, os relacionamentos estabelecidos pessoalmente e a troca de conhecimentos são muito importantes, juntamente com a oportunidade de conhecer pessoas novas. A grande vantagem dos cursos oferecidos via Internet seria a economia de tempo, especialmente porque evita deslocamentos desnecessários.

Outras objeções foram levantadas pelos grupos. Para um dos homens entre 22 e 35 anos, o curso pela Internet seria muito básico, em função dos poucos recursos disponíveis para um bom aprendizado. Na opinião de um homem acima de 35 anos, outro empecilho seria o próprio acesso à Internet, ainda muito lento quando feito no domicílio. Foi enfatizada a necessidade de banda larga, via rádio, com maior velocidade no acesso. Não seria possível fazer o curso com uma conexão lenta, que cai a toda hora. O custo foi citado pelo grupo de homens entre 22 e 35 anos, que acreditam ser muito cara a realização de um curso pela Internet. Por isso, um deles só faria tal curso se fosse possível receber o material por e-mail.

Algumas mulheres acima de 35 anos fariam curso superior pela Internet, pois seria uma oportunidade para aqueles que não chegaram ao $3^{\circ}$ grau. No entanto, uma delas considera que o curso superior é muito sério para ser feito pela Internet, pois haveria 
necessidade de um espaço de discussão que não fosse superficial, o que provavelmente ocorreria, pela Internet. Um homem acima de 35 anos declarou que só faria um curso de aperfeiçoamento na própria área em que trabalha, porque já possui algum conhecimento. Do contrário, para ele o curso se limitaria a informações teóricas, sem a possibilidade de aplicar o conhecimento na prática. Além disso, alguns cursos seriam muito difíceis de serem feitos pela Internet, como os que necessitam da utilização de ferramentas ou outros, como os de Medicina ou Engenharia. Seriam viáveis os cursos relacionados ao manuseio do computador e de alguns softwares e, mesmo assim, em caso de curso superior, dependeria da área.

Outro aspecto relevante diz respeito a diferenças na valorização do curso feito pela Internet em relação aos cursos tradicionais, realizados em sala de aula. Segundo a opinião de um morador (homem acima de 35 anos), os cursos realizados on line não seriam reconhecidos por qualquer empresa e, portanto, seriam uma perda de tempo e dinheiro. Entre os homens na faixa de 22 a 35 anos, também há o medo de o curso não ser reconhecido.

\section{Emprego, negócios e transações pela Internet}

O conhecimento de informática foi uma unanimidade, entre os participantes, no que se refere a facilitar a contratação de pessoal, por melhorar o currículo do candidato ao cargo. A exigência de uma maior especialização é sentida por todos os entrevistados. No grupo de homens e mulheres de 16 a 22 anos, a informática e o conhecimento de língua estrangeira foram apontados como essenciais para se conseguir um emprego. Além disso, dois rapazes (16 a 22 anos) precisaram ter conhecimento sobre informática para crescerem profissionalmente. Um deles trabalha com vendas e foi promovido a operador de telemarketing, o que não ocorreria se ele não soubesse manusear o computador. Outro trabalha fazendo a manutenção de computadores, incluindo limpeza, instalação de programas etc. Para este grupo, a apresentação de certificados não seria uma garantia de contratação, pois seria necessária uma demonstração prática de conhecimentos. 
No entanto, um dos homens acima de 35 anos perdeu uma oportunidade de trabalho por não ter feito cursos de informática, apesar de possuir conhecimento na área. Foi uma exigência da empresa que ele apresentasse certificados. Segundo um dos entrevistados, o mercado de trabalho, principalmente para quem ultrapassou os 30 anos, está cada vez mais difícil. Ele sugere maior flexibilidade das empresas, no sentido de verificar o interesse do candidato e a possibilidade de ele evoluir no cargo, e não apenas de querer um funcionário já pronto. Outro participante faz uma queixa em relação às oportunidades oferecidas à população carente. Hoje em dia não há, nas escolas públicas, uma sala com laboratório de informática para os alunos. Para ele, o Brasil não tem e não oferece estrutura para o usuário adquirir conhecimento e se aperfeiçoar.

Entre as mulheres acima de 35 anos, o conhecimento de informática favoreceu a obtenção de emprego. Uma delas explica que a informática ajudou-a não apenas a conseguir um trabalho, como também a descobrir uma vocação. Ela ganhou uma bolsa para o curso de informática e foi convidada pelo professor para auxiliá-lo nas aulas. A partir disso, descobriu que tinha dom para ensinar e investiu num curso normal, formando-se em professora e passando a ministrar aulas, tanto de informática como no ensino fundamental. Outras dizem que o computador não as auxiliou a conseguir emprego, mas melhorou a qualidade e facilitou seu trabalho, trazendo-lhes um aperfeiçoamento pessoal.

No grupo dos homens entre 22 e 35 anos, um disse que lamentava não ter aprendido a usar o computador antes, para se atualizar. Ele acha que perdeu oportunidade de ascensão dentro da empresa, porque não tinha conhecimentos relativos ao computador. Outros dois conseguiram promoção, pelos conhecimentos sobre computação.

Para o grupo de lideranças comunitárias, que abarca desde professores de ONG, coordenadores de instituições comunitárias a presidentes de associações de moradores, atualmente os empregos exigem informática. Portanto, saber mexer no computador ajuda na conquista de emprego, pois abre portas. No entanto, foi levantado que não seria suficiente saber informática, mas seria fundamental ter conhecimentos básicos, como saber utilizar a própria língua portuguesa, tanto oral quanto escrita. Uma das coordenadoras de instituição comunitária apontou que o problema é o conhecimento 
em informática ser avaliado como um fim, e não como uma ferramenta, um meio para se conseguir outras coisas.

Neste grupo, uma outra coordenadora de instituição comunitária tinha apenas noções básicas de informática, e precisou aperfeiçoar seus conhecimentos para poder realizar melhor seu trabalho. Outra relatou que o desconhecimento de informática não lhe dificultou encontrar emprego, até porque praticamente não havia micro em seu trabalho. No entanto, ela acha que facilita o trabalho, e por isso está aprendendo algumas coisas com a filha, como, por exemplo, colocar nomes e idades das crianças da creche em arquivos. A falta de um computador para os serviços da instituição torna o trabalho mais difícil e demorado, pois tudo tem que ser escrito a mão, desde fichas das crianças a ofícios.

No grupo de mulheres de 22 a 35 anos, algumas precisaram aprender a utilizar o computador para continuar no emprego. Também foi ressaltado que atualmente é necessário que a pessoa saiba pelo menos ligar o computador, porque nas empresas o ponto já é eletrônico.

Um rapaz na faixa de 16 a 22 anos (Maré) ganha dinheiro com o computador $e$ demonstra vasto conhecimento na área de informática. Ele elabora sistemas (recentemente fez um para a SERVAS), edição de imagens e vídeos, animação 3D, sites, currículos, edita cartas, slogans, designer, e, na Internet, sabe programar o HTML. Outro rapaz, na faixa de 22 a 35 (Rocinha) também utiliza o computador para ganhar dinheiro, especialmente com recursos audiovisuais e trabalhos administrativos. Ele faz logomarcas, cartão de visitas, cria os desenhos que utiliza, faz marcas personalizadas. Para isso, usa, por exemplo, o photoshop. Um deles é um homem acima de 35 anos que trabalha atualmente com PhotoShop e Corel Drawn. Ele é músico e desenvolveu a capa do próprio $C D$ que, através de um personagem roqueiro, fala do cotidiano e das mazelas das comunidades carentes. Seu trabalho é divulgado pela Internet.

Para essas pessoas, o uso da informática vai muito além da própria utilização no emprego. Até o cliente de bancos precisa saber algo de informática, para utilizar os caixas eletrônicos e fazer pagamentos, saques ou digitar sua senha.

Com relação à utilização da Internet para fazer negócios, em geral os participantes dos grupos focais não consideram um espaço seguro para isso. Grande parte não faria 
compras ou transações bancárias que implicassem movimentação de dinheiro. Muitos utilizam a Internet apenas para comparação de preços, consulta de saldo, impressão de $2^{a}$ via para pagamento de contas e cadastramento de CPF. Um dos jovens de 16 a 22 anos acredita que acessar banco pela Internet é perigoso, e que por mais proteção que o sistema garanta, é sempre possível alguma invasão. A maioria dos homens de 22 a 35 anos não confia na Internet e não a utilizaria para pagar contas.

Os que já realizaram transações bancárias ou compras continuam inseguros com relação à Internet. Uma das mulheres de 22 a 35 anos já fez transferência de dinheiro de um banco para outro. Ela acha mais prático fazer este tipo de procedimento pela Internet. No entanto, por uma questão de segurança, prefere ir pessoalmente ao banco. O fornecimento do número do cartão de crédito é visto pelas mulheres acima de 35 anos como o procedimento mais perigoso, quando se trata de compras pela Internet. Outro morador (homem 22 a 35 anos) acessa sites de banco apenas para ver o saldo, e só faz compras pela Internet através de boleto bancário.

A necessidade de examinar o produto para conferir se é de fato aquilo que se deseja adquirir também foi apontado como um dos problemas em caso de compras pela Internet. Um dos homens acima de 35 anos desistiu de fazer um negócio, porque tinha que efetuar o pagamento sem ter o produto em mãos. Um jovem de 16 a 22 anos também prefere ver o produto antes de realizar a compra, além de ter o nome de quem o atendeu, para depois ter a quem procurar. No entanto, a Internet não oferece essa facilidade. Um dos rapazes de até 16 anos comprou, pela Internet, um instrumento cujo fone estava quebrado. Ele perdeu muito tempo para conseguir reclamar e, por isso, não compraria novamente. Outro tentou comprar, mas havia muitos formulários a preencher e, assim, acabou desistindo.

Sites de lojas conhecidas, como Lojas Americanas ou Shoptime, deixam os usuários mais tranqüilos para adquirir algum produto. Alguns homens acima de 35 anos fariam compras pela Internet, caso conhecessem a loja.

Uma das mulheres acima de 35 anos já realizou várias transações bancárias e se sente completamente segura, pois acha que quem vai arcar com as conseqüências, caso ocorra algum problema, é o próprio banco. Outras mulheres deste grupo fariam 
compras pela Internet, apesar de nunca terem experimentado. O que as impede é o preço dos produtos, que são considerados mais caros, e também a impossibilidade de fazerem compras com cartão ou cheque.

Por curiosidade, um dos participantes (homem acima de 35 anos) entrou em contato com um grupo no qual ele poderia aprender a ser um hacker. Para tanto, ele teria que fazer um depósito e receberia informações sobre como ter acesso à conversa alheia, senhas de celulares, etc. Ele preferiu não completar a operação.

\section{7 - Como o e-mail é utilizado}

Somente $4.6 \%$ dos habitantes da favela usam e-mail, ou seja, menos da metade dos usuários de Internet, e um quarto dos usuários de computador:

\section{Gráfico 2.7.1: Percentual de uso de e-mail em relação à utilização de microcomputador e Internet}

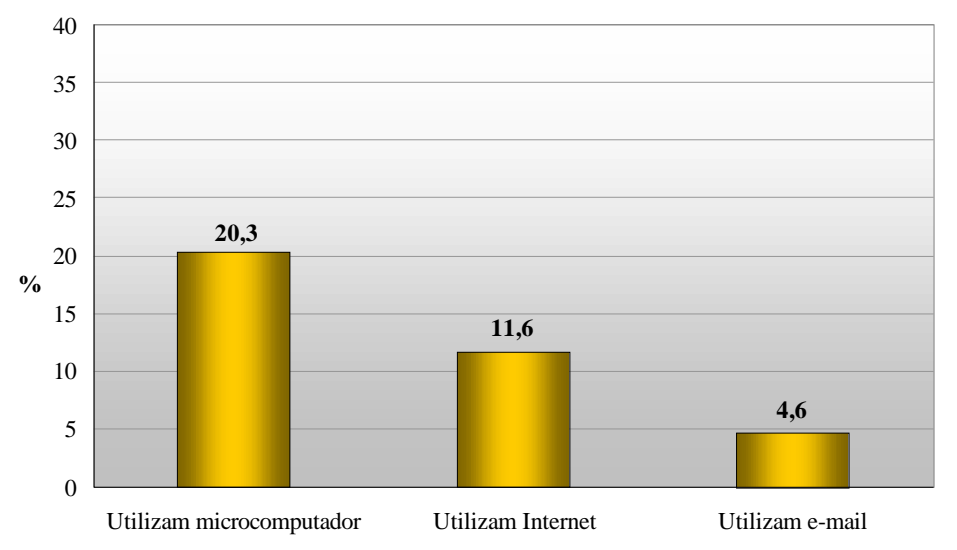

A relação entre uso de e-mail e faixa etária indica uma tendência inesperada: embora seja ainda preponderante o uso de e-mail na faixa mais jovem da população, a distância entre os grupos etários, no uso de e-mail, se comparada com a distância entre as faixas etárias no uso de computador e Internet, tende a diminuir: 
Gráfico 2.7.2: Percentual de utilização de e-mail segundo a faixa de idade, nas comunidades de baixa renda do município do Rio de Janeiro

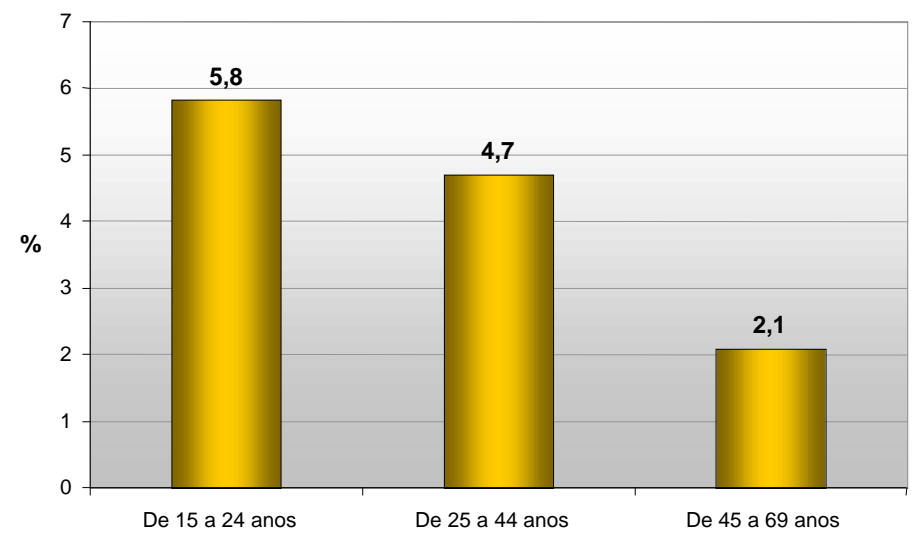

Nota: Os percentuais foram calculados em relação ao próprio grupo.

Na utilização de e-mail volta a se reproduzir o fenômeno de exclusão feminina,

Gráfico 2.7.3: Utilização de e-mail, segundo sexo, nas comunidades de baixa renda do município do Rio de Janeiro

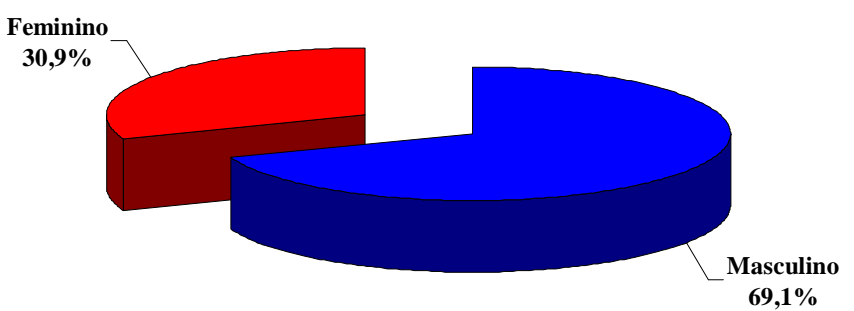

Universo: os que utilizam e-mail ( 4,6\% da população).

Em relação à cor, constatamos que o diferencial relativo entre brancos, negros e pardos é de certa forma baixo, se comparado aos diferenciais de renda, escolaridade e posse de computador. Possivelmente tal resultado está associado ao fenômeno, já mencionado, de acesso no trabalho: 
Gráfico 2.7.4: Percentual de utilização de e-mail, segundo a cor, nas comunidades de baixa renda do município do Rio de Janeiro

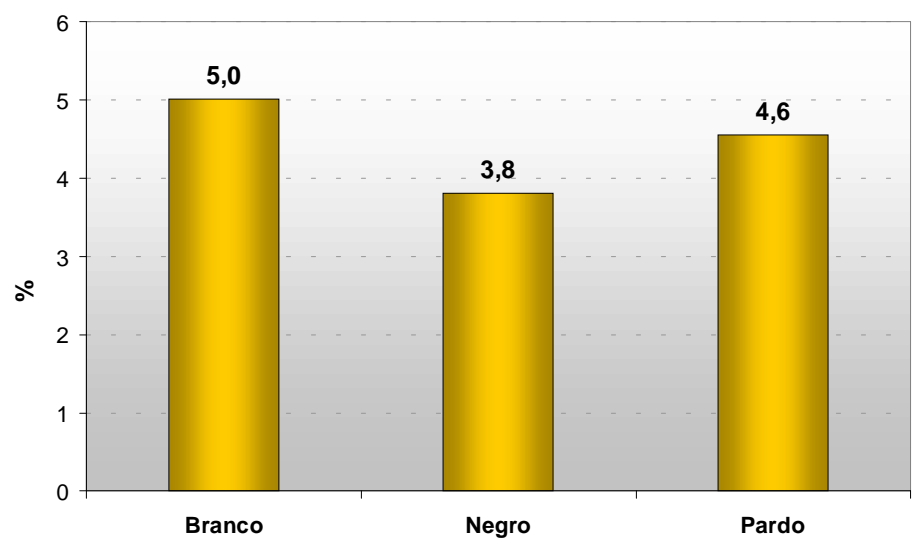

Nota: Os percentuais foram calculados em relação ao próprio grupo.

No tocante a nível de escolaridade, porém, a distância no uso de e-mail adquire sua maior expressividade - a diminuição do percentual de usuários de e-mail entre os grupos de maior escolaridade, em relação ao nível imediatamente inferior, deve-se provavelmente à margem de erro técnico produzido pelo pequeno número de entrevistados com escolaridade superior a 15 anos:

Gráfico 2.7.5: Percentual de utilização de e-mail, segundo o nível educacional, nas comunidades de baixa renda do município do Rio de Janeiro

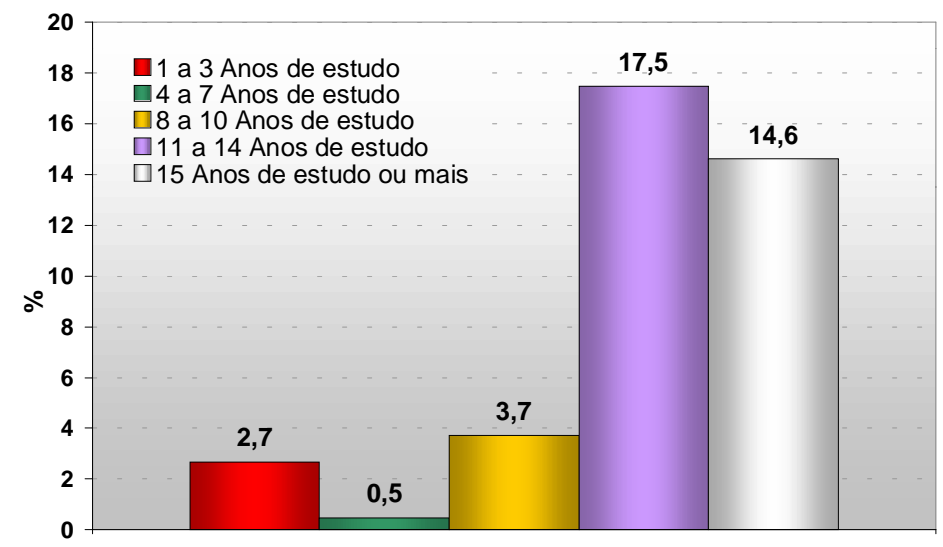

Nota: Os percentuais foram calculados em relação ao próprio grupo. 
O diferencial no nível de renda reproduz porcentagens similares às de uso de Internet e computador,

Gráfico 2.7.6: Renda pessoal e familiar per capita média, segundo a utilização de e-mail, nas comunidades de baixa renda do município do Rio de Janeiro

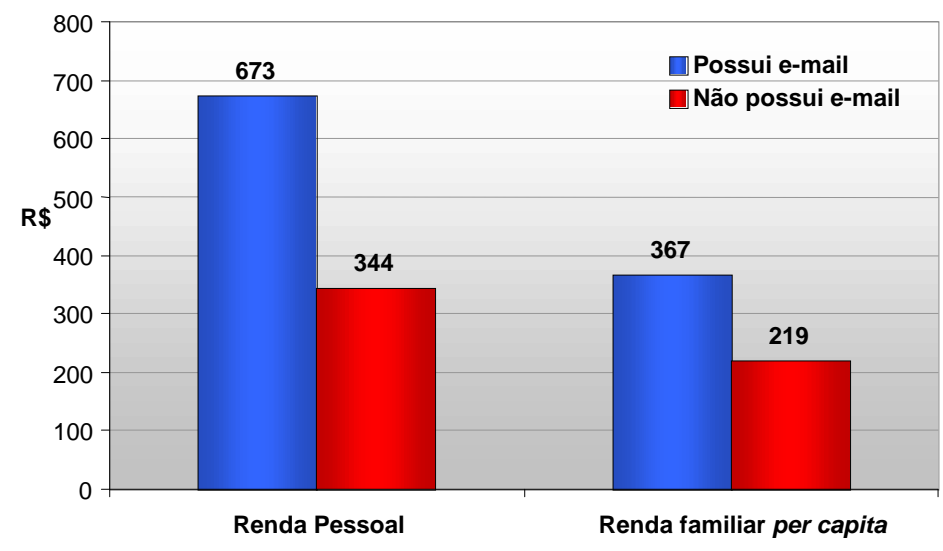

A intensidade no uso do e-mail é indicada no gráfico a seguir:

Gráfico 2.7.7: Freqüiência de utilização de e-mails nas comunidades do município do Rio de Janeiro

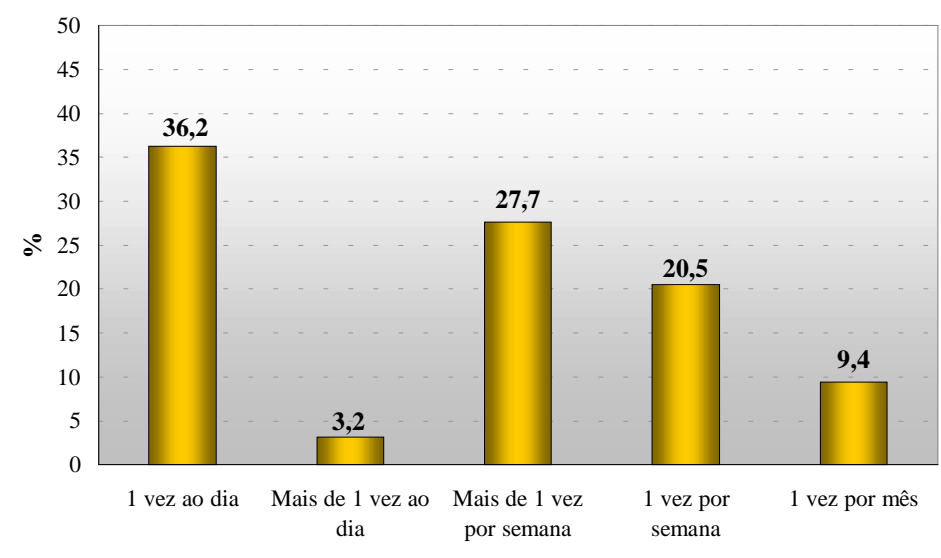

Universo: Os que usam e-mail ( 4,6\% da população).

O e-mail é usado, majoritariamente, para comunicação com para amigos e parentes.

Seu uso profissional ainda é limitado, o que pode ser explicado pelo tipo de ocupação exercida pelo usuário de e-mail em favela, bem como por sua sociabilidade, pois grande parte de seu entorno social não tem acesso à Internet ou a e-mail. 
Gráfico 2.7.8: Principais remetentes e destinatários de e-mails, nas comunidades de baixa renda do município do Rio de Janeiro

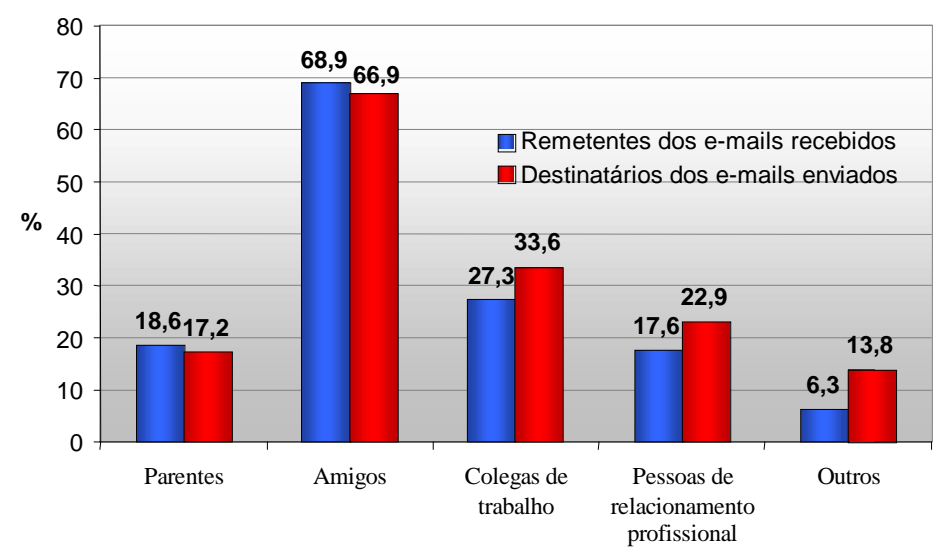

\section{Uso do e-mail}

Em geral, quatro a seis participantes de cada grupo utilizam o e-mail para comunicação. As mulheres entre 22 e 35 anos, e os homens entre 22 e 35 e acima de 35 anos usam o e-mail com maior freqüência e possuem um número mais expressivo de nomes em sua lista de comunicação, girando em torno de 20 a 50 pessoas. As mulheres dessa faixa utilizam e-mail mais para diversão, e sua lista é constituída basicamente por familiares e amigos. Entre os homens, o uso se divide: metade utiliza mais para trabalho, enquanto a outra parte tem o uso mais direcionado para diversão. A lista de um deles tem em torno de 100 pessoas, entre amigos, colegas, parentes e pessoas de outros países, com as quais mantém contato constante.

É comum jovens até 16 anos terem mais de uma conta de e-mail, com motivos específico: para trabalho, diversão, amigos ou sala de bate-papo. Um deles usa dois e-mails, por causa do limite das caixas. Assim, ele acessa o e-mail secundário quando o outro está cheio. O uso do e-mail neste grupo é basicamente voltado para diversão, e a lista é constituída, em geral, de amigos.

As mulheres acima de 35 anos verificam seu e-mail, em geral uma vez por semana. A lista de comunicação dessas mulheres contém por volta de 4 pessoas (parentes e 
amigos). Apenas a que verifica diariamente o e-mail possui um número maior de contatos, girando em torno de 30 a 40 pessoas, incluindo amigos, família e colegas de trabalho.

A maioria dos jovens entre 16 e 22 anos já não verifica seu e-mail há algum tempo. Um deles relatou ter vários e-mails, pois está sempre esquecendo a senha, por utilizar pouco a Internet. Então acaba fazendo novo e-mail. Outro participante não está mais conseguindo acessar, porque o e-mail foi desativado por pouco uso. Eles têm poucas pessoas na lista de comunicação, que normalmente é constituída por família e amigos. Apenas um deles acessa diariamente seu e-mail, tendo por volta de 500 contatos, voltados tanto para trabalho quanto para diversão.

A maioria das lideranças comunitárias (professor de ONG, coordenadores de instituições comunitárias e presidente de associação de moradores) tem e-mail e o utiliza diariamente para contatos de trabalho e também de amizade. O presidente de uma associação de moradores tem e-mail, mas quem o acessa são seus filhos, já que ele não sabe como usá-lo.

\section{8 - Telecentros: o caso das Estações Futuro}

As Estações Futuro, que atualmente totalizam 12, são telecentros da ONG Viva Rio, estabelecidos em Campo Grande, Cesarão, Itararé, Macaé, Maré, Rocinha, Santa Cruz, São Cristóvão, Urucânia, Itaguaí e na Barraca da Feira de São Cristóvão. ${ }^{7}$ Do total da população das favelas, as 12 Estações Futuro são indicadas por 7.3\% dos usuários como o principal local de acesso e, nas favelas em que existe uma Estação, esta porcentagem sobe para $30 \%$ do total de usuários. O impacto nas comunidades pode ser medido nos gráficos 2.8.1, 2.8.2 e 2.8.3. 
Gráfico 2.8.1: Percentual de uso de microcomputadores, segundo a existência de Estação Futuro

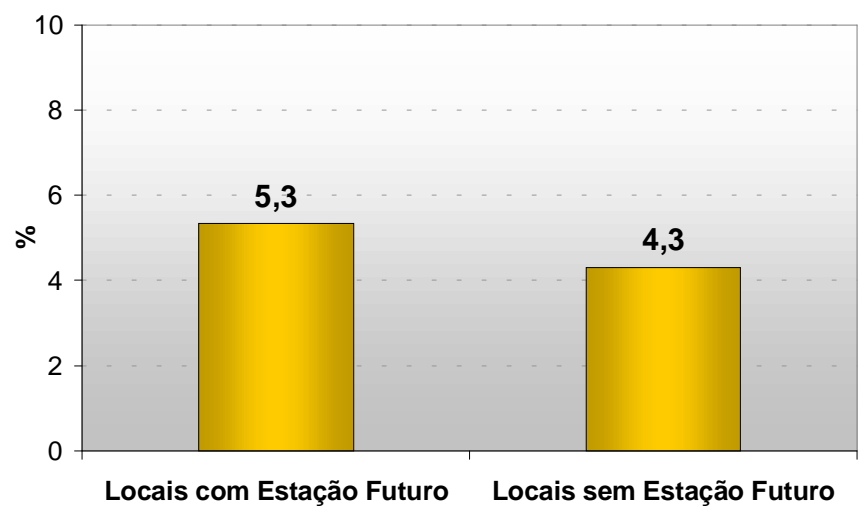

Gráfico 2.8.2: Percentual de uso de Internet, segundo a existência de Estação Futuro

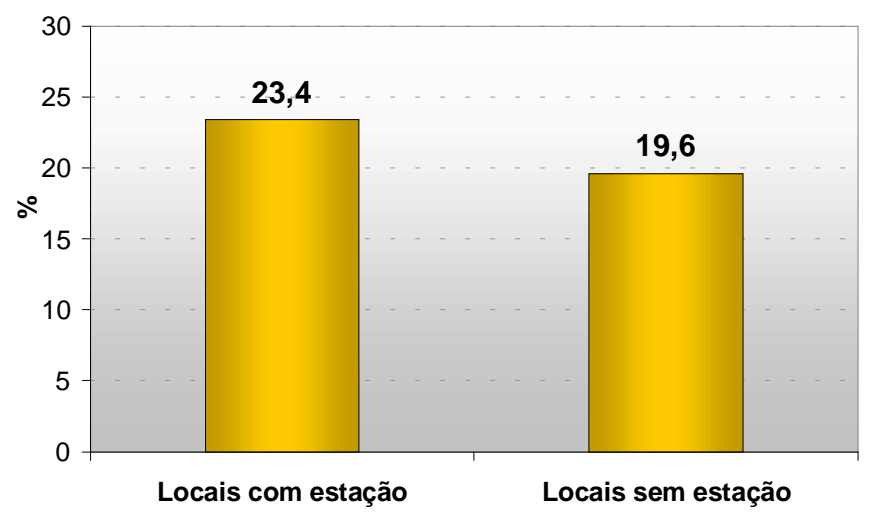

Gráfico 2.8.3: Percentual de uso de e-mail, segundo a existência de Estação Futuro

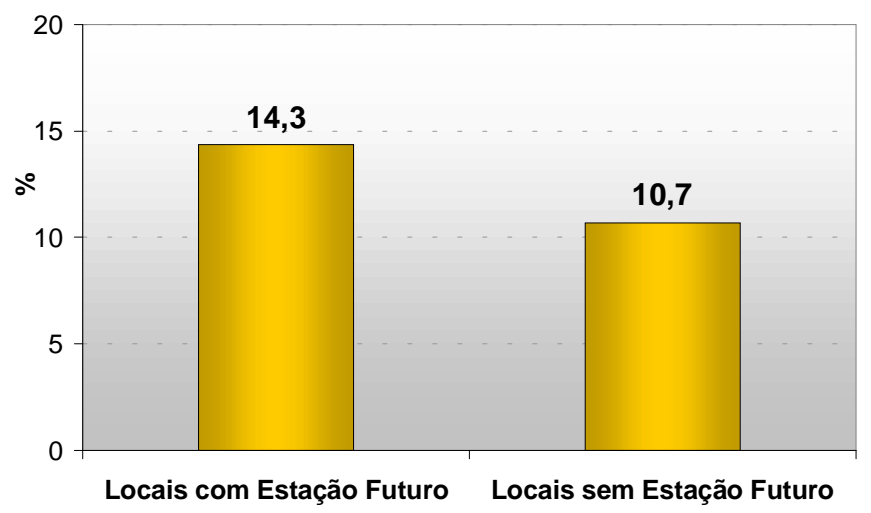

${ }^{7}$ Ver Sorj, B. brasil@povo.com - a luta contra a desigualdade na Sociedade da Informação. Rio Janeiro, 
Em todos os casos, a presença da Estação Futuro indica um impacto positivo no aumento de acesso à informática e à Internet. Em termos dos padrões gerais analisados anteriormente, as Estações Futuro mostram que a distância entre os sexos se mantém, assim como em relação aos negros. Tais aspectos serão vistos no último capitulo, a partir da análise dos dados mais detalhados sobre as favelas onde existe Estação Futuro.

\section{Gráfico 2.8.4: Utilização de Internet e Estação Futuro, segundo a cor}

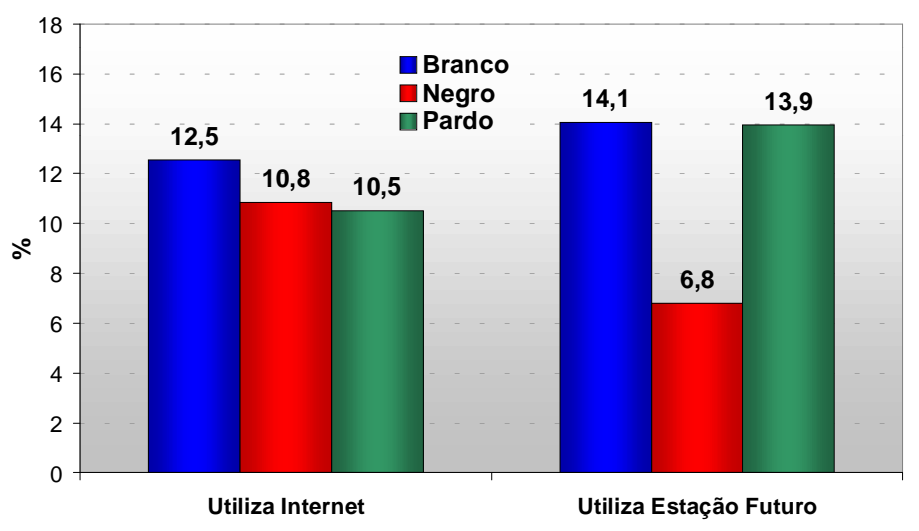

$\mathrm{O}$ acesso à Internet nas Estações Futuro tem um custo, ainda que inferior ao praticado pelos cybercafés privados, de forma que seus usuários tendem a pertencer aos setores com maior poder aquisitivo da favela, fator que é neutro em relação a gênero, mas desfavorece a população negra que, em geral, se situa nos grupos de renda inferior. 
Gráfico 2.8.5: Renda pessoal e familiar per capita média, segundo utilização da Internet

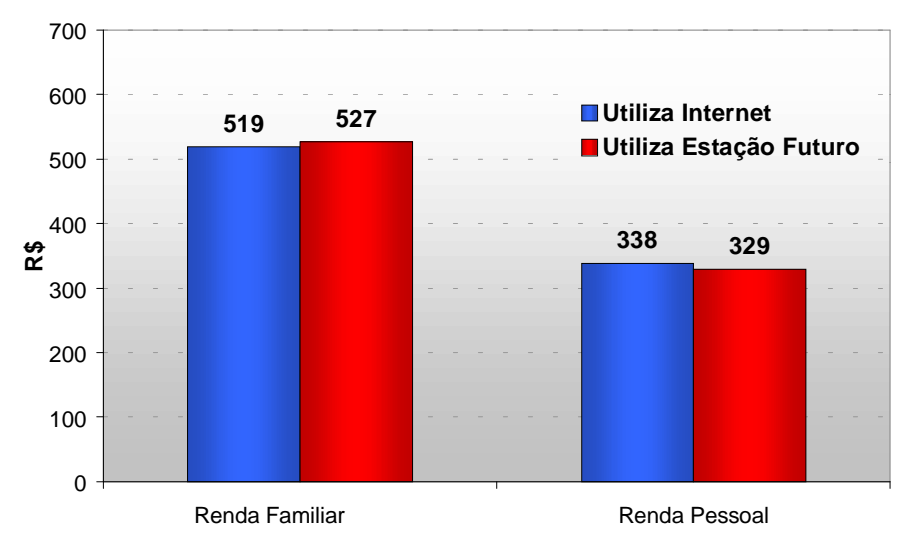

As Estações Futuro são um fator nivelador em termos de faixa etária, pois seu público tem uma média de idade mais alta que o dos usuários de Internet. Uma possível explicação pode estar no apoio que as Estações Futuro oferecem ao usuário, como os serviços de procura de emprego, assim como na maior disponibilidade financeira das pessoas de mais idade, em relação ao público juvenil.

Gráfico 2.8.6: Utilização de Internet e Estação Futuro, segundo a faixa de idade

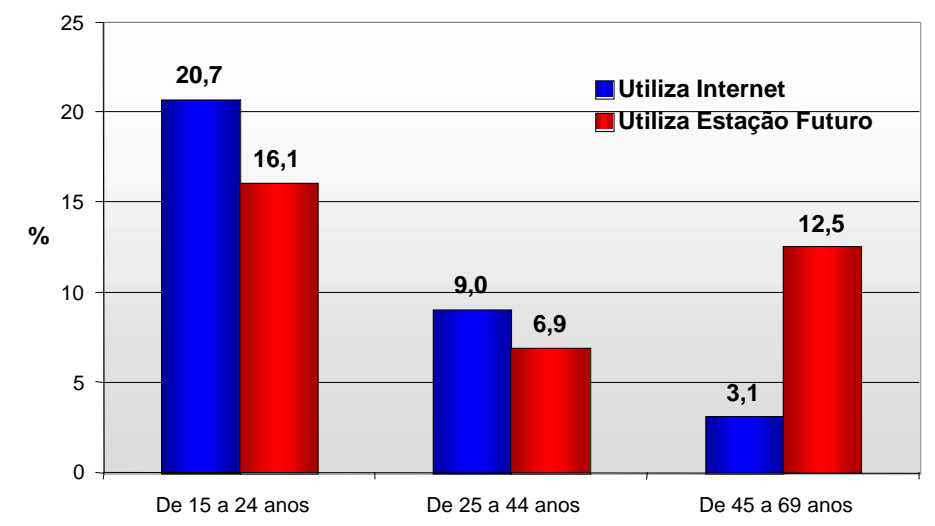

\section{Estação Futuro}

A maioria dos participantes dos grupos já utilizou, ou ainda utiliza, a Estação Futuro, à exceção do grupo de não-usuários da Internet. Apenas um rapaz (até 16 anos) declarou que nunca foi à Estação, por não ter muito interesse e por utilizar computador 
em casa de parentes, e apenas para trabalhos escolares. Os jovens até 16 anos que ainda utilizam a Estação, o fazem com certa regularidade, e freqüentam-na cerca de uma vez por semana. No grupo de mulheres com mais de 35 anos, uma das principais razões para a utilização da Estação Futuro é a melhor conexão da Internet. Da mesma forma, as mulheres de 22 a 35 anos, mesmo aquelas que possuem computador no domicílio, preferem acessar a Internet na Estação Futuro, pois fica mais barato.

Todos os que representavam lideranças comunitárias (professor de ONG, coordenadores de instituição comunitária e presidente de associação de moradores) conhecem as atividades da Estação Futuro. Aqueles que não possuem computador na instituição, ou em casa, utilizam a Estação Futuro com regularidade. Uma das instituições comunitárias da Rocinha, que funciona principalmente como creche, utiliza a Estação para relatórios, ofícios, cartas. Dependendo da necessidade, a freqüência à Estação é de uma a duas vezes na semana. Uma das coordenadoras de instituição comunitária relatou que utiliza a Estação Futuro quando precisa fazer um ofício com melhor apresentação, mas normalmente usa o mimeógrafo. Na verdade, ela utiliza a Estação com maior freqüência para assuntos pessoais, pois tem uma amiga na França, que está sempre enviando e-mails. Geralmente é sua filha quem vai até lá, e lhe traz as mensagens impressas.

A razão mais comum para a não-utilização da Estação é a posse de computador no domicílio. Mesmo assim, os jovens de 16 a 22 anos ainda costumam ir à Estação Futuro quando não conseguem acessar a Internet em casa. Também os jovens de até 16 anos que possuem computador, quando a conexão com a Internet não está boa no domicílio, vão à Estação. Algumas lideranças comunitárias, especialmente aquelas que trabalham na coordenação de instituições comunitárias, freqüentam a Estação Futuro somente quando ocorre algum problema com a Internet, ou com o computador.

Apenas um dos participantes do grupo de não-usuários conhecia a Estação Futuro. Ele a descobriu quando passava em frente e viu os cartazes indicativos dos preços dos serviços. Ele achou uma boa iniciativa, pois favorece aqueles que não têm onde acessar a Internet. No entanto, achou o espaço físico muito pequeno (quiosque no piscinão), além de pouco confortável. 
Apesar de existirem outros pontos de acesso à Internet na Rocinha, a Estação Futuro é considerada o melhor deles pelos participantes do grupo de jovens (até 16 anos). Um dos problemas levantados se refere à velocidade das máquinas na Estação Futuro, que deveriam ser mais rápidas. A falta de fones para escutar música e o número de computadores disponíveis também foram apontados como aspectos que poderiam ser melhorados.

Quanto à velocidade no acesso aos sites na Internet, os homens e mulheres de 22 a 35 anos também acham muito lenta. No entanto, o grupo de jovens de 16 a 22 anos considera que, apesar de alguns computadores demorarem um pouco mais, de forma geral o acesso não poderia ser considerado lento.

O número de máquinas disponíveis também foi um dos pontos abordados pelas mulheres entre 22 e 35 anos e por aquelas acima de 35. Dependendo do horário, é preciso ficar aguardando outra pessoa terminar, para poder acessar. Por isso, seria interessante haver um maior número de micros. Uma das mulheres com mais de 35 anos sugeriu que fosse feita uma promoção em horário especifico, exatamente quando a sala é menos utilizada.

Em relação ao espaço físico, todos os participantes o consideram bom e confortável, com exceção das mulheres de 22 a 35 anos (Rocinha). Para elas, a Estação Futuro já foi mais confortável, e o espaço é muito pequeno. O ar condicionado, apesar de central, parece não funcionar, porque a sala está sempre com uma temperatura inadequada.

O grupo de jovens entre 16 e 22 anos fez apenas elogios ao trabalho realizado na Estação Futuro. No entanto, o grupo de homens de 35 anos acha que a recepção estar instalada na sala de computadores é ruim, devido ao intenso barulho. Além disso, há sempre muito bate-papo, o que atrapalha quem está ali para trabalhar e precisa de concentração.

As mulheres de 22 a 35 anos também reclamaram do barulho. Além disso, a falta de privacidade foi apontada como um dos problemas da Estação. Uma delas se sente constrangida quando um homem se senta a seu lado para acessar o site da Playboy, e outras gostariam de ficar mais à vontade quando fossem fazer seus trabalhos, ou 
mesmo navegar pela Internet. Para evitar tais situações, foi sugerida a utilização de cabines reservadas.

A maioria dos grupos considera o atendimento bom, pois as funcionárias estão sempre disponíveis para tirar dúvidas. No entanto, dois homens de 22 a 35 anos reclamaram de mau atendimento. As funcionárias não deram atenção a suas dúvidas. Por isso, deveria haver uma melhor preparação do pessoal para lidar com o público. Um deles tentou acesso em outro local, e foi melhor atendido.

Com relação ao custo para utilização da Estação Futuro, apenas no grupo de homens acima de 35 anos houve queixas acerca dos valores cobrados. Um deles relatou que possui poucos recursos, o que dificulta e até mesmo impossibilita a utilização constante de computador. Ele acessa pouco a Internet porque, apesar de ser barato, ele não possui uma renda fixa, e muitas vezes o pouco que tem é para comprar comida, não podendo passar 4 ou 5 horas na Internet, em casa ou no Viva Rio. Por isso, tem que acessar sempre rapidamente, já sabendo o que vai mandar, e não pode ficar pesquisando. Como é músico, às vezes precisa mandar uma música em MP3, só que na Estação Futuro é preciso baixar o mídia player pela Internet, o que já toma muito tempo. Por ser de comunidade de baixa renda, ele sugere que seja feita uma pesquisa para verificar quem realmente é carente e necessita de Internet. Poderia, por exemplo, ser feito um sorteio de algumas horas gratuitas por mês, para essas pessoas.

Outro homem do mesmo grupo sugeriu que o uso do computador fosse separado do acesso à Internet. A idéia é cobrar valores diferenciados para serviços apenas com textos e para acesso à Internet. Também foi recomendado que os melhores computadores deveriam ser usados exclusivamente para acessar a Internet e os outros, com menos recursos, para trabalhos mais simples. Já no grupo de jovens de 16 a 22 anos, foi sugerida uma taxa mensal, que daria direito a um certo número de horas de utilização. 


\section{Organizações localizadas nas favelas e uso da informática}

Uma das instituições participantes do grupo focal é uma ONG que atua principalmente na área de educação, em escolas, a partir de parcerias (com a Petrobras, por exemplo). Funciona como escola preparatória, oferecendo diversos cursos para a comunidade, do ensino fundamental ao pré-vestibular. Essa instituição possui dois laboratórios de Informática, um deles para atender à comunidade e o outro, aos alunos. Além disso, conta com computadores que pertencem a outros projetos. No curso de informática, é oferecido um pacote básico (Windows, Excel, Power Point) e cobrada uma taxa para a apostila, que não cobre o orçamento de pessoal, mas somente o material didático. A Internet, no entanto, é de uso apenas dos funcionários, pois ainda se aguarda a liberação da verba de um projeto para a compra de material de estrutura para prover o suporte. Tudo na instituição funciona a partir do uso do computador, incluindo a elaboração de documentos.

Em um centro esportivo, cultural e educacional da prefeitura, localizado na Maré, há computadores no setor administrativo e também um laboratório de informática que oferece cursos gratuitos, do básico ao avançado, abrangendo todos os programas. A maior parte dos computadores foi doada por parceiros; no máximo dois deles foram comprados. Como a procura é muito grande, existe uma lista de espera. Só depois da construção de uma segunda sala, já prevista, será possível atender melhor à demanda da comunidade. O acesso à Internet é limitado aos funcionários da administração, pois ainda não se conseguiu parceria para a instalação deste acesso para os usuários.

Uma instituição comunitária, que oferece creche e cursos voltados para a educação como alfabetização de jovens e adultos - possui computadores que, embora de uso da Secretaria, podem eventualmente ser utilizados para trabalhos dos alunos. Esses computadores, que foram doados, agilizam informações e dão maior flexibilidade no trabalho do dia-a-dia da instituição.

Outra instituição, que funciona basicamente como creche, oferece também cursos de artesanato para mulheres desempregadas da comunidade, e conta com um só 
computador, que não acessa a Internet. A coordenadora da instituição declarou que gostaria de ter mais computadores para capacitar jovens. Este trabalho seria realizado por outros jovens que sabem mexer no micro, e que já se disponibilizaram para ajudar no curso. Ela acredita que, ao trazer jovens para a instituição, estará ajudando a tirálos das ruas e da violência. No entanto, ainda aguarda alguma doação, já que não pode comprar os computadores. 


\section{3 - Segunda Parte}

\section{1 - Análise por tipo de favela}

A Segunda parte deste livro tem como base uma segunda pesquisa, realizada nos meses de outubro e novembro de 2003, focalizando unicamente usuários de computação e Internet. Nosso objetivo foi o de aprofundar o conhecimento específico dos usuários, nas favelas do Rio de Janeiro. Considerando a heterogeneidade desse universo, decidimos pesquisar uma favela de maior nível de ingresso (Rocinha), três favelas de ingresso médio (Maré, Rio das Pedras e Dona Marta) e duas favelas de ingresso baixo (Jacaré e Jacarezinho). Esta diferenciação entre favelas deve, porém, ser qualificada, já que todas elas têm um significativo nível de heterogeneidade interna, que se expressa, inclusive, em uma segmentação espacial. É o caso particular da favela da Maré, na prática um conglomerado de favelas, oito grandes comunidades que, em seu processo de expansão, criaram um continuum habitacional.

A seguir, apresentaremos o perfil das favelas do município do Rio de Janeiro, tomando como referência os dados da primeira pesquisa, representativa dos adultos maiores de 15 anos, do conjunto das comunidades do município do Rio de Janeiro. Nesta segunda pesquisa, foram selecionadas duas favelas que possuem Estação Futuro: Rocinha e Maré, esta representada por 8 grandes comunidades - Parque Maré, Nova Holanda, Baixa do Sapateiro, Parque União, Rubens Vaz, Morro do Timbau, Praia de Ramos, Roquete Pinto - e 18 favelas que não têm Estações Futuro: Alto da Bela Vista, Canal do Anil, Mangueira, Fazenda Coqueiro, Formiga, Favela do Jacaré (Santíssimo), Jacarezinho, Joaquim Queiroz, Morro da União, Nova Brasília, Parque Alegria, Parque Royal, Parque São Jorge, Pavão-Pavãozinho, Vila Cruzeiro, Vila Rica de Irajá, Vila São Jorge, Vila Vintém.

Como indica o gráfico abaixo, a renda média per capita, tomando-se como referência os salários das pessoas com declaração de fonte de renda, é de $6.5 \%$ entre favelas altas e médias, e de $16 \%$ entre favelas medias e baixas. 
Gráfico 3.1.1: Renda média pessoal, por classe de favela

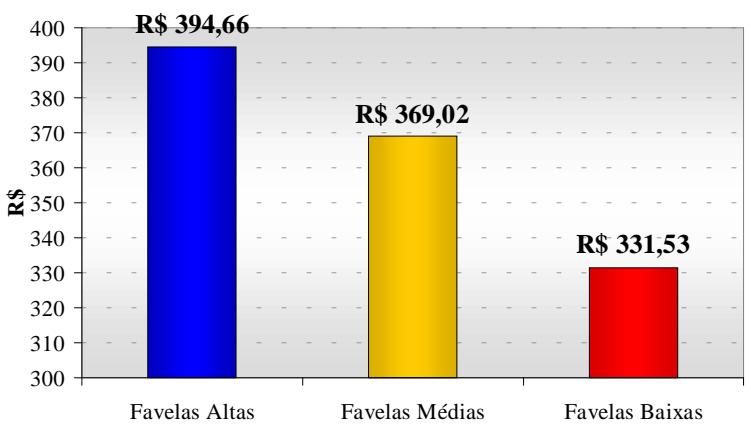

Gráfico 3.1.2: Diferencial da renda pessoal, por classe de favela

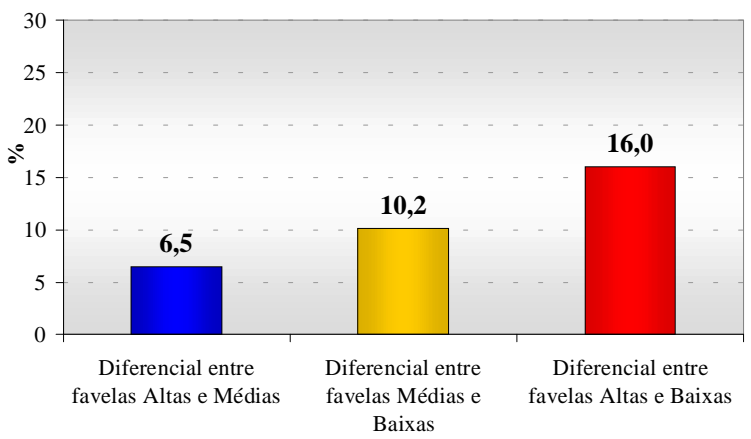

Este diferencial se modifica, quando analisamos a renda média familiar, mantendo-se ele entre favelas médias e altas, mas aumentando a desigualdade em relação às favelas baixas. Como veremos adiante, os possíveis fatores de explicação para tal diferencial se relacionam a um maior número de filhos, distribuição da população por cor e o nível educacional inferior das favelas baixas.

Gráfico 3.1.3: Renda média familiar, por classe de favela

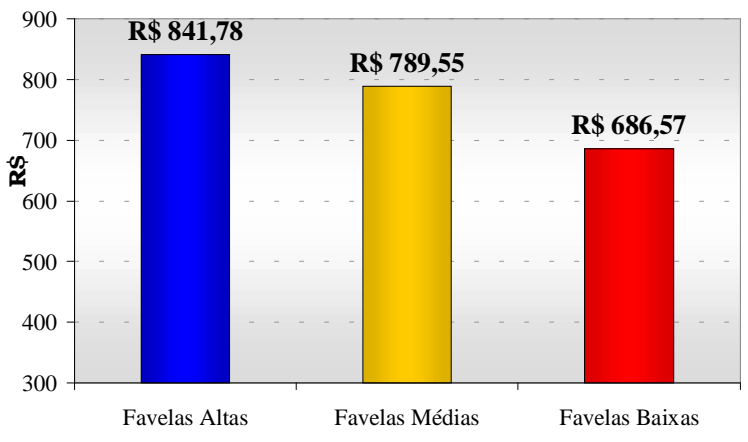


Gráfico 3.1.4: Diferencial da renda familiar, segundo a classe de favela

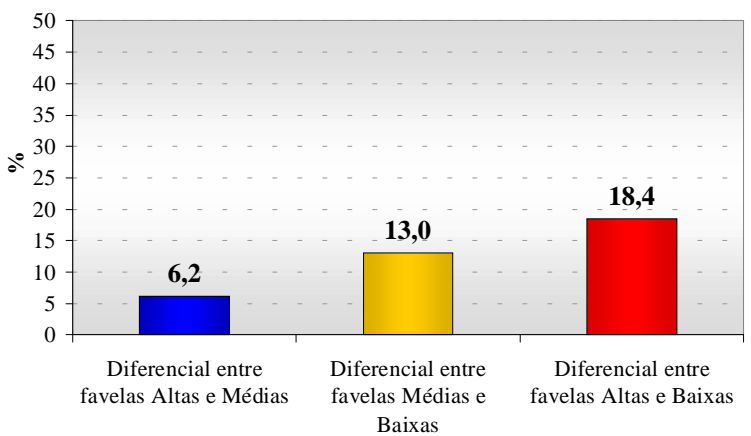

A hipótese acima se confirma nos gráficos a seguir, nos quais são apresentados os diferenciais de anos de estudos e número de filhos:

Gráfico 3.1.5: Média de anos de estudos, por classe de favela

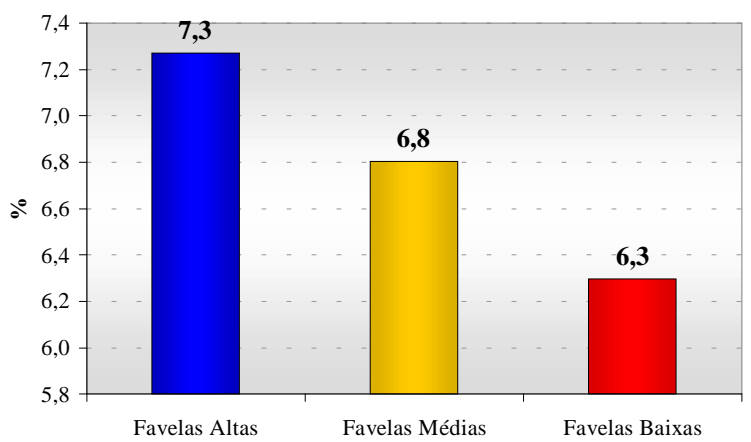

Gráfico 3.1.6: Média de número de filhos, por classe de favela

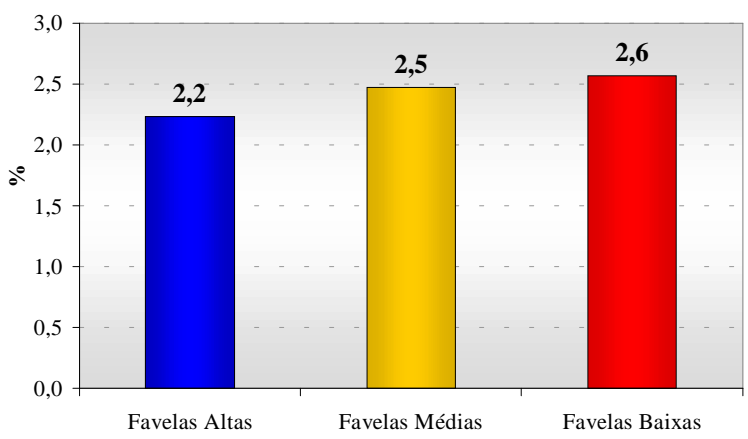

A distribuição do sexo por favelas apresenta, em geral, uma maior porcentagem de população feminina, refletindo a proporção encontrada no conjunto da população brasileira. 


\section{Gráfico 3.1.7: Distribuição do sexo, por classe de favela}

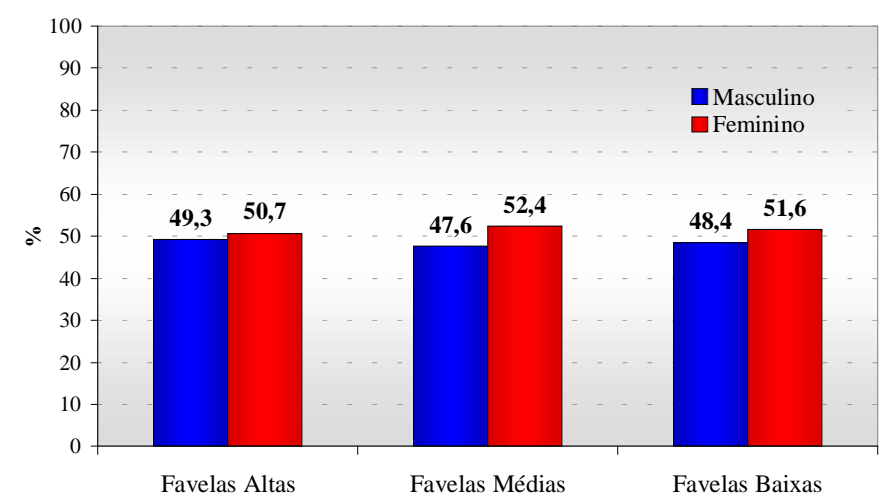

A distribuição por idade, nas favelas, não apresenta maiores diferenciais, a não ser por uma leve preponderância da população jovem, na medida em que se passa das favelas altas para as de menor renda, produto natural de um maior número de filhos por família.

\section{Gráfico 3.1.8: Distribuição da faixa de idade, por classe de favela}

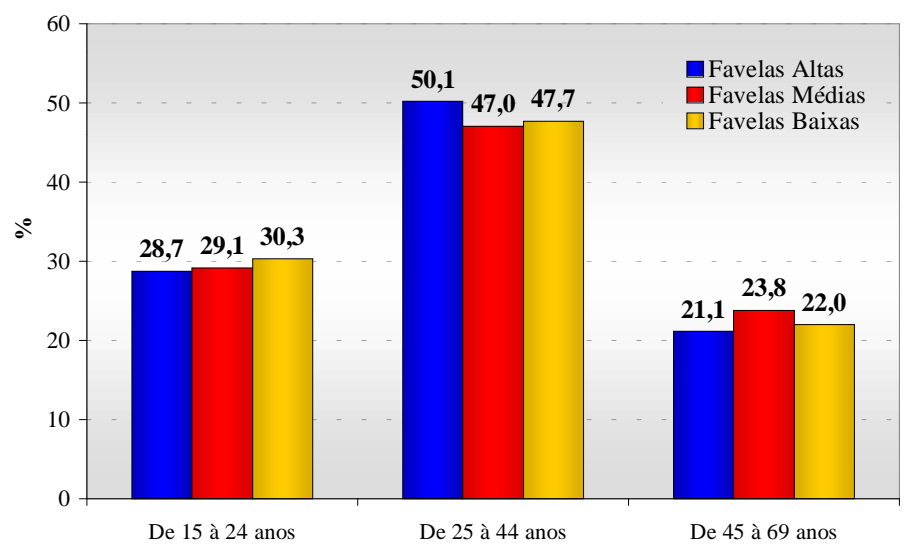

A distribuição por cor (auto-definida) entre os diferentes tipos de favelas apresenta uma nítida separação entre as favelas altas e as outras. Enquanto nas favelas altas existe um claro predomínio de brancos, nas favelas médias e baixas predomina a população parda. Considerando-se que a renda média dos brancos, é bastante superior a dos negros, se pode dizer que este é um dos fatores que explicam a renda superior das favelas altas. 
Gráfico 3.1.9: Distribuição de cor/raça, por classe de favela

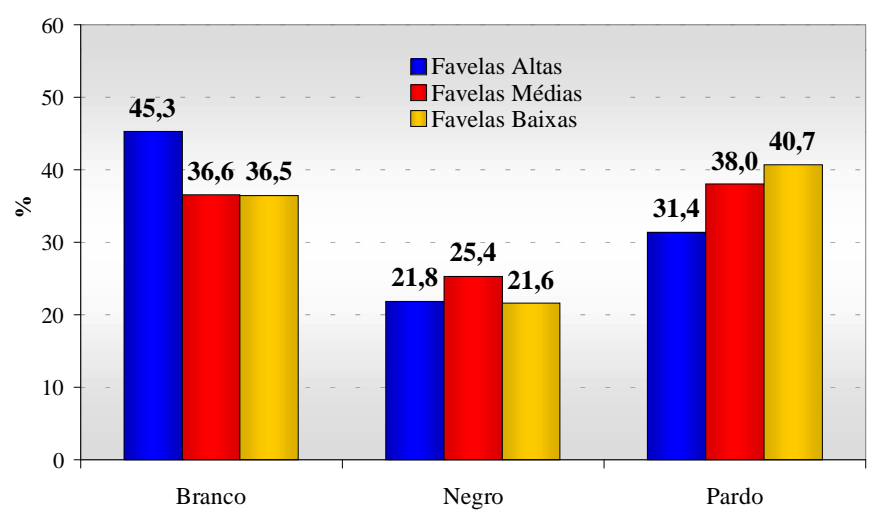

Como mostra o gráfico a seguir, a população branca tem renda familiar superior à das populações parda e negra.

Gráfico 3.1.10: Média de renda familiar per capita

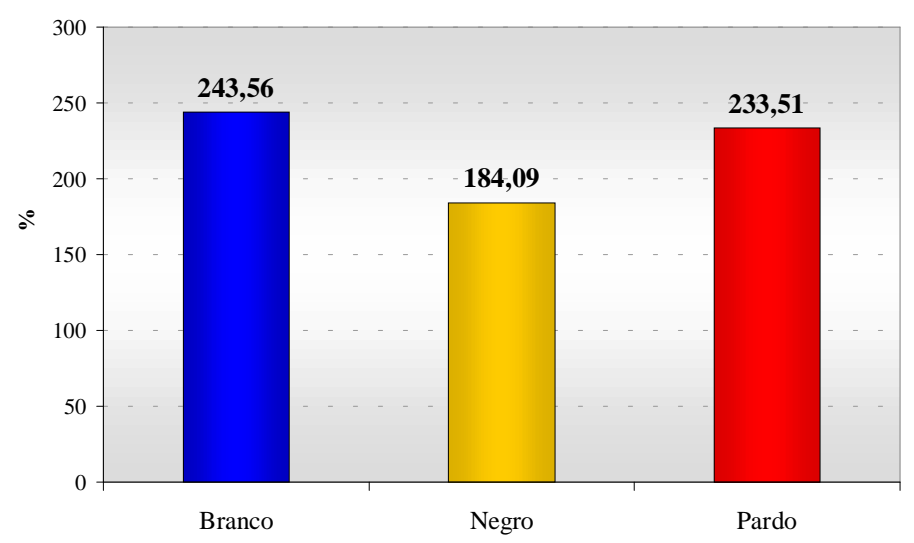

Vale ressaltar também que o ingresso das famílias pardas e negras é diferente, de acordo com o tipo de favela.

Tabela 3.1.1: Média de renda familiar per capita por cor/raça, segundo a classificação por tipo de favela

\begin{tabular}{|c|c|c|c|}
\hline Cor/Raca & Favelas Altas & Favelas Médias & Favelas Baixas \\
\hline Branco & 268,75 & 234,49 & 235,97 \\
\hline Negro & 233,28 & 204,20 & 137,03 \\
\hline Pardo & 265,37 & 274,65 & 186,57 \\
\hline
\end{tabular}


O numero de cômodos por favela é inverso à renda. Isto porque o custo de aluguel ou compra é menor nas favelas baixas. Um outro fator, como mostra o próximo gráfico, é que o número de pessoas por domicílio vai aumentando, na medida em que o ingresso diminui.

Gráfico 3.1.11: Média de cômodos utilizados como dormitório, por classe de favela

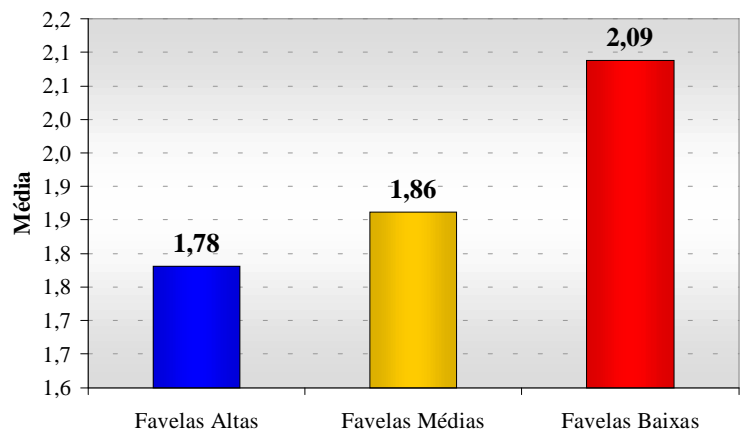

Gráfico 3.1.12: Média de pessoas em cada domicílio, por classe de favela

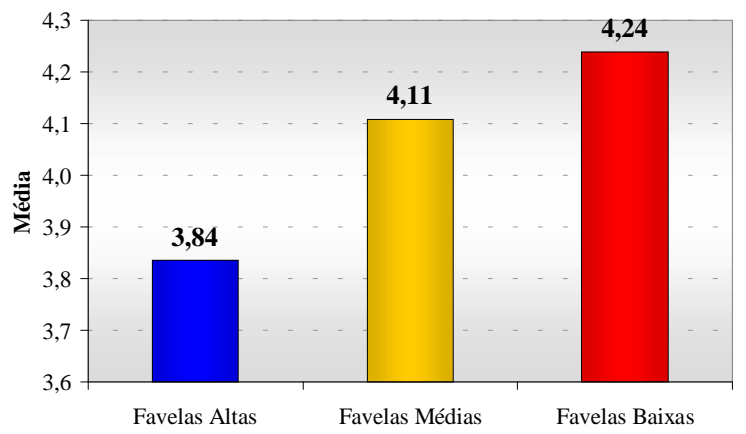

Como mostra o gráfico a seguir, a posse de computadores acompanha o nível de renda nas favelas.

Gráfico 3.1.13: Distribuição segundo a posse de computador, por classe de favela

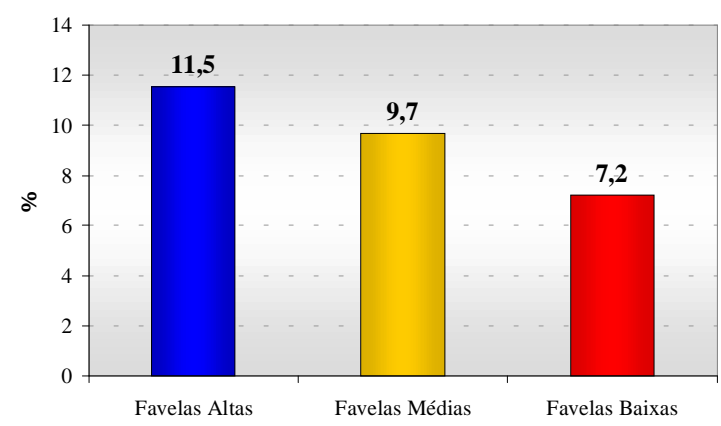


O diferencial entre utilizadores de computador tende a diminuir em relação à posse, entre os moradores de favelas baixas e médias. A explicação pode ser encontrada na primeira parte deste trabalho, onde mostramos que a maioria dos usuários tem acesso à informática fora do lar. Como mostra o gráfico abaixo, o acesso fora do lar aumenta na medida em que a renda diminui, já que as chances de possuir um computador no domicílio também diminuem:

\section{Gráfico 3.1.14: Distribuição segundo a utilização de computador, por classe de favela}

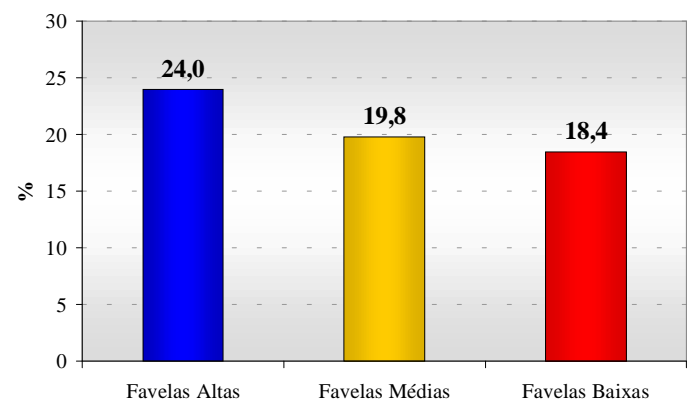

\section{2 - Análise dos usuários de informática e de Internet}

Neste capítulo, analisaremos, detalhadamente, apenas o universo dos usuários. Assim, todos os gráficos têm como referência esse universo. Inicialmente, indicamos que a porcentagem de usuários do sexo masculino é superior à dos usuários do sexo feminino. Como vemos no gráfico a seguir, esta tendência é constante, independentemente do tipo de favela: 
Gráfico 3.2.1: Utilização de computador por classe de favela, segundo o sexo

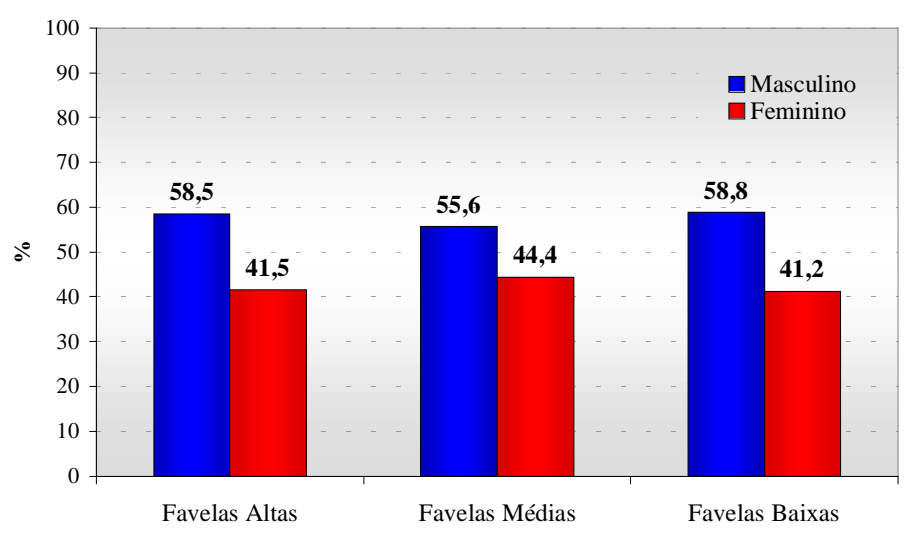

A seguir, o gráfico da distribuição de usuários segundo a cor indica que, enquanto nas favelas baixas essa distribuição acompanha as porcentagens relativas destes grupos no total da população, nas favelas altas e médias, a porcentagem de usuários brancos é superior ao percentual destes na população em geral. No caso da população parda, nas favelas altas a porcentagem de usuários é superior ao percentual deste grupo na população em geral, enquanto nas favelas médias e baixas é ligeiramente inferior.

Gráfico 3.2.2: Uso de microcomputador por classe de favela, segundo a cor

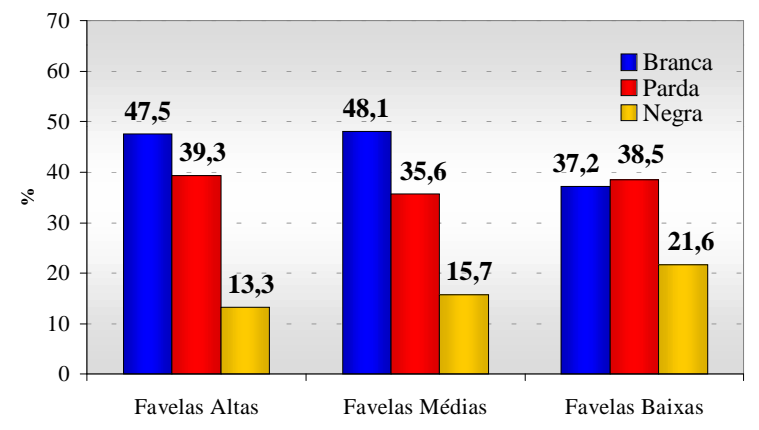

Gráfico 3.2.3: Distribuição de cor/raça, por classe de favela

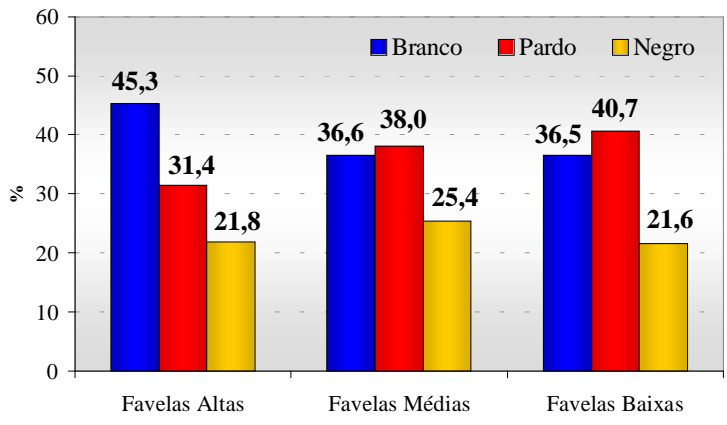


A distribuição dos usuários de computador por religião acompanha, em geral, a porcentagem de cada religião no total da população, com exceção das favelas altas, onde os sem religião apresentam um percentual significativamente superior, e das favelas baixas, onde o percentual de evangélicos é bastante superior ao da população em geral.

Gráfico 3.2.4: Uso de microcomputador por classe de favela, segundo a religião

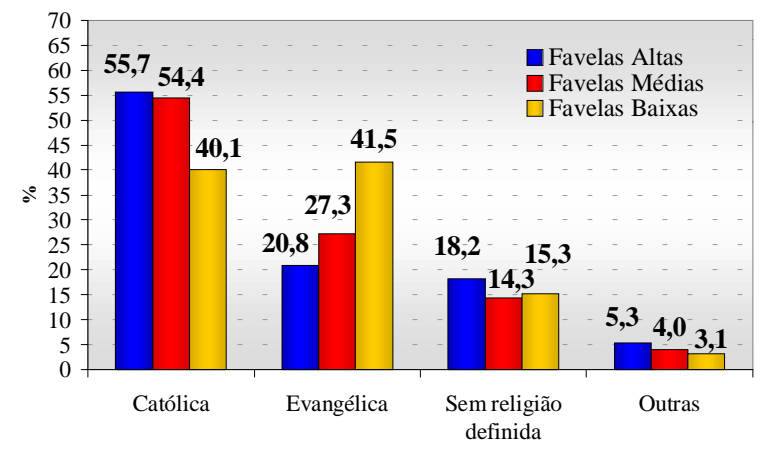

Gráfico 3.2.5:. Distribuição da religião, por classe de favela

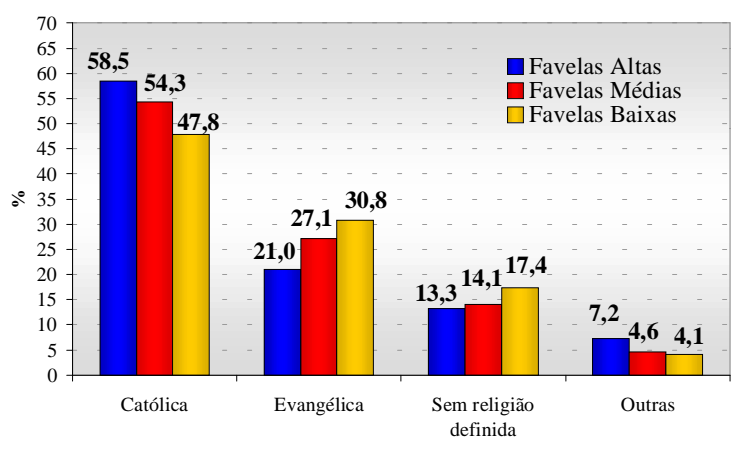

Em termos de renda pessoal, o gráfico 3.2.6 indica que:

a) A maioria dos usuários não tem renda, isto é, em geral são filhos, em idade escolar, que estão estudando.

b) O número dos usuários sem renda aumenta nas favelas médias e baixas, onde o número de filhos é maior do que nas favelas altas. Embora nas favelas baixas o número de filhos também seja grande, o decréscimo de usuários deve ser 
relacionado ao fato de o nível de renda e de escolaridade das famílias ser mais baixo.

c) O principal diferencial de renda entre as favelas se concentra no percentual de pessoas com mais de 2.400 reais mensais, que chega a $3.7 \%$ nas favelas altas, contra $1,2 \%$ e $0.5 \%$ nas favelas médias e baixas, respectivamente.

\section{Gráfico 3.2.6: Distribuição segundo a faixa de renda mensal dos moradores que utilizam computador, por classe de favela}

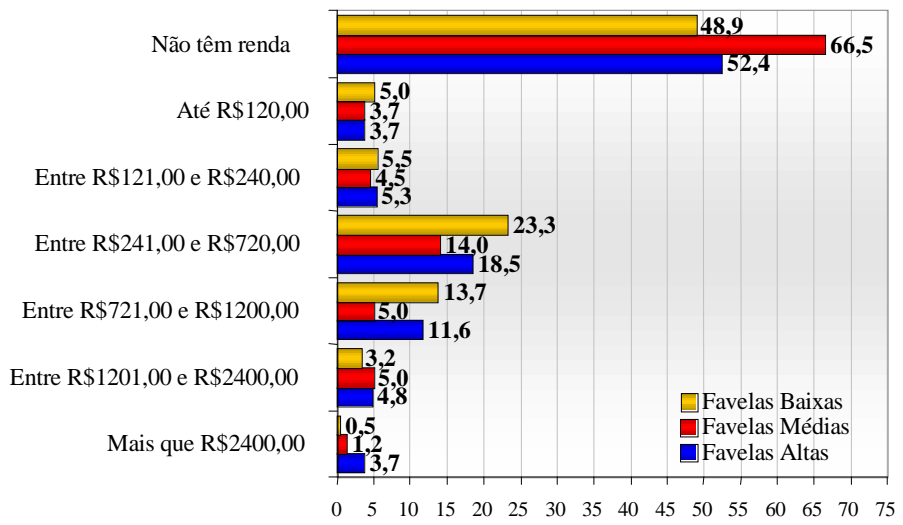

A distribuição de renda dos usuários sofre algumas modificações, quando se trata da renda familiar, que tende a aumentar relativamente nas favelas médias e baixas, como produto do maior número de filhos.

Gráfico 3.2.7: Distribuição dos moradores que utilizam computador, por classe de favela, segundo a faixa de renda familiar mensal

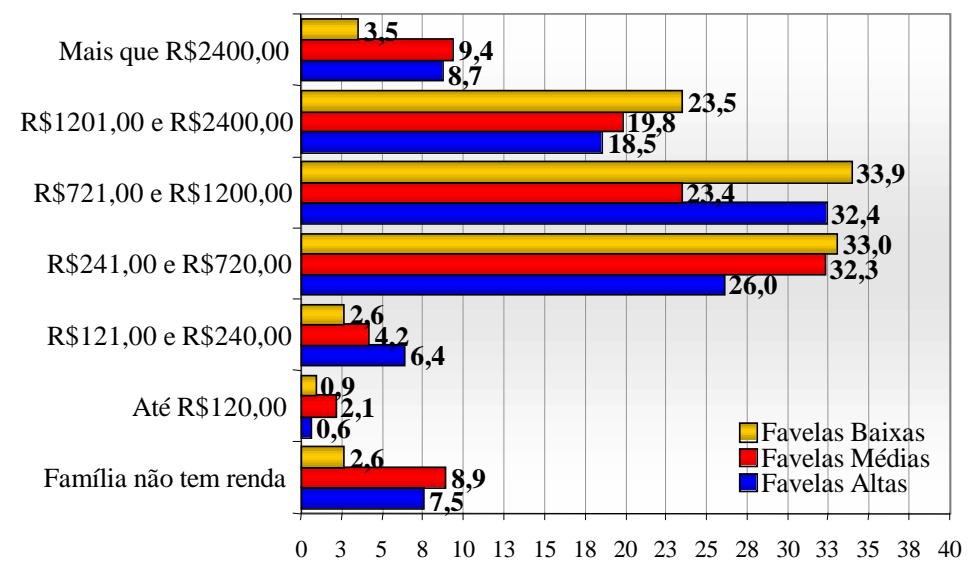


Como mostram os gráficos a seguir, chega quase à metade o número de usuários que, no momento, estão estudando. São em geral crianças e jovens. Em relação aos usuários de 7 a 14 anos, enquanto nas favelas altas todos eles estão estudando, nas favelas médias 4.6\% deixaram de estudar, e nas favelas baixas $8.3 \%$ também pararam os estudos.

Gráfico 3.2.8: Utilização de computador por classe de favela, segundo atual frequiência à escola

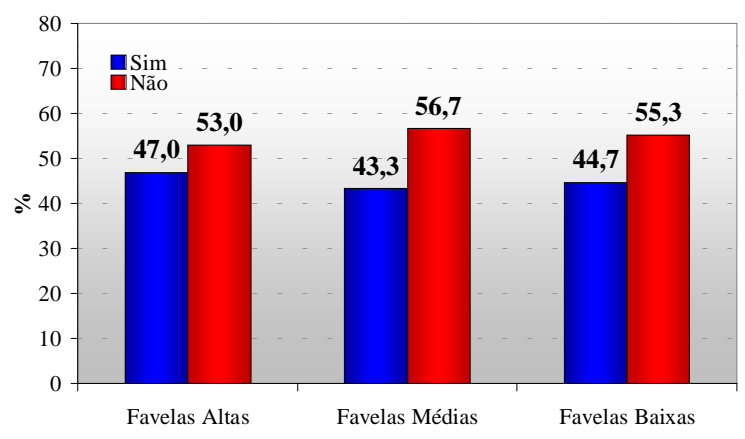

Gráfico 3.2.9: Utilização de microcomputador porusuários entre 7 e 14 anos, por classe de favela, segundo atual freqüência à escola

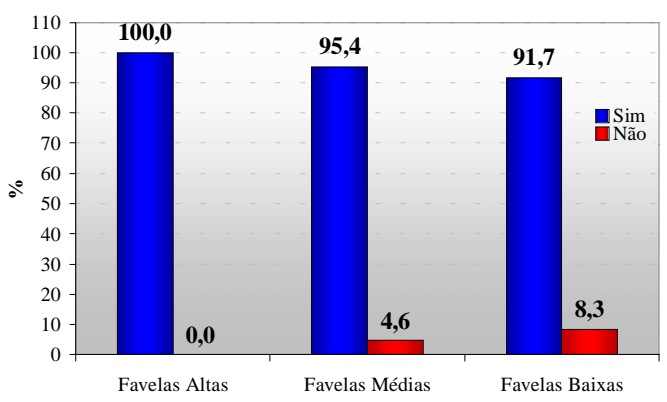

O próximo gráfico mostra o drama dos moradores das favelas: quanto mais pobre é a favela, maior é a porcentagem de estudantes em escolas privadas. A razão disto está no fato de que as favelas cujos moradores têm maior renda, por serem mais antigas e melhor localizadas, usufruem de uma rede educacional pública mais adequada. Um fator adicional é que em favelas com população de renda mais baixa é maior o número de pessoas que procuram cursos supletivos privados, para compensar o atraso escolar, ou que fazem cursos técnicos profissionalizantes, como indica o próximo gráfico: 
Gráfico 3.2.10: Utilização de computador por classe de favela, segundo o tipo de escola que frequientou

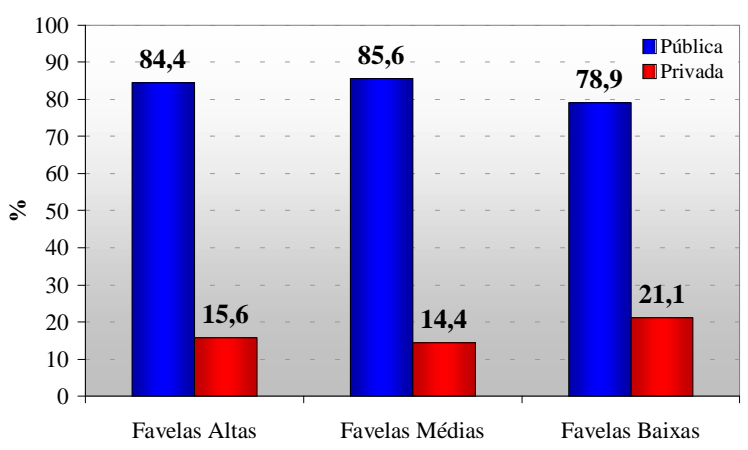

Gráfico 3.2.11: Utilização de computador por classe de favela, segundo o tipo de ensino de cursos anteriores ou atuais

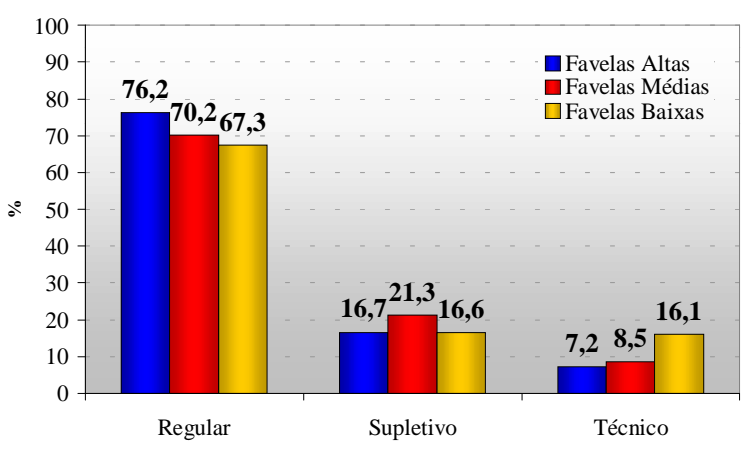

Cerca de quatro quintos das escolas freqüentadas pelos usuários de micro possuem computador. Porém, menos da metade desses alunos pode utilizá-lo, com exceção dos alunos das escolas das favelas baixas. Aí, a porcentagem é ligeiramente superior a 50\%, o que deve ser creditado ao fato de, nestas favelas, ser alto o percentual de pessoas que estudam em escolas privadas, nas quais existe computador.

Gráfico 3.2.12: Utilização de computador por classe de favela, segundo a existência de micro na escola

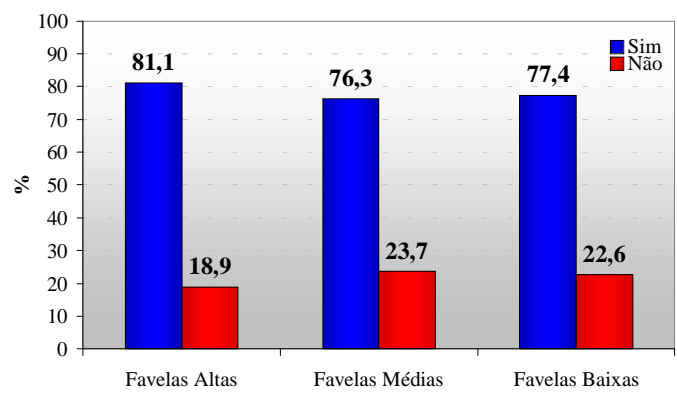


Gráfico 3.2.14: Utilização computador por classe de favela, segundo a possibilidade de uso do micro na escola

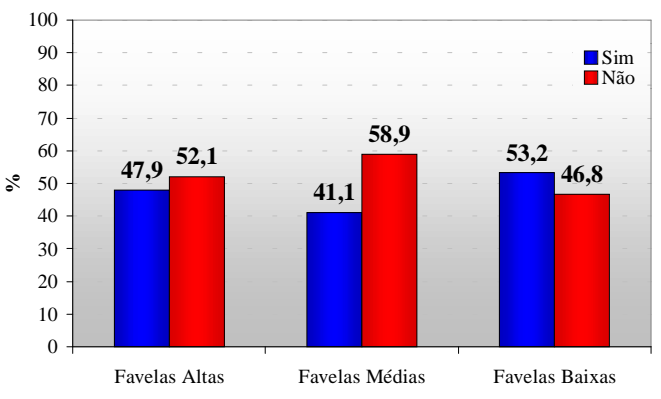

Gráfico 3.2.13: Utilização de computador por classe de favela, segundo a presença de Internet na escola

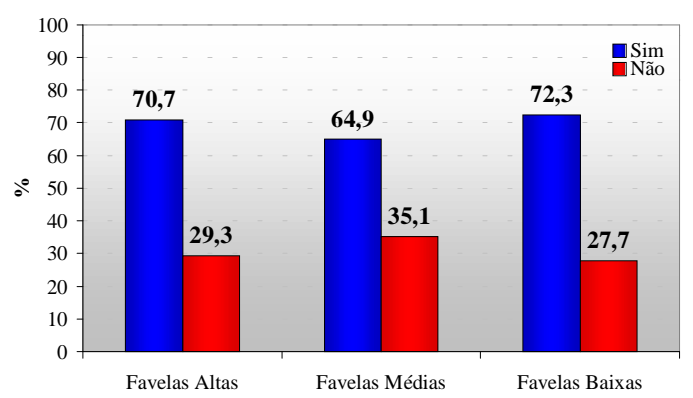

Gráfico 3.2.15: Possibilidade de uso da Internet na escola, por classe de favela

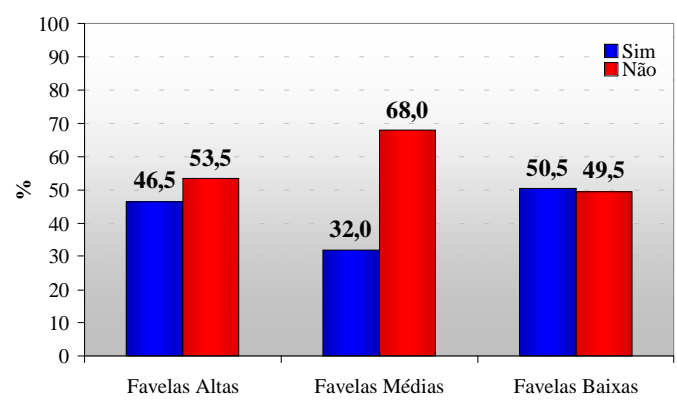

A periodicidade do uso do computador, segundo o tipo de favela, não se modifica de forma relevante. Em torno de 30\% dos usuários utilizam o computador diariamente, e outros $30 \%$ utilizam-no pelo menos uma vez por semana. 
Gráfico 3.2.16: Freqüência de utilização do computador, por classe de favela

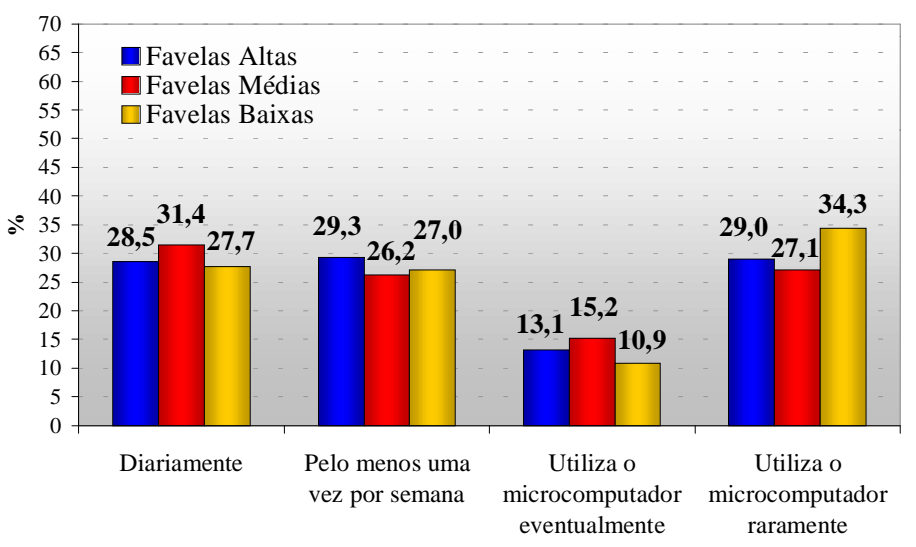

Como mostra a tabela a seguir, em todas as favelas as pessoas tendem a aprender a usar o computador em cursos especializados, tendência essa que aumenta nas favelas baixas, onde as chances de aprender em casas de amigos é menor:

Tabela 3.2.1: Maneira como aprendeu a usar o microcomputador, por tipo de favela

\begin{tabular}{|c|c|c|c|}
\hline & Favelas Altas & Favelas Médias & Favelas Baixas \\
\hline \multicolumn{4}{|l|}{ Maneira de aprendizado } \\
\hline Sozinho, por tentativas & 17,0 & 15,5 & 12,8 \\
\hline Sozinho, c/ ajuda de manuais & 1,8 & 1,1 & 2,9 \\
\hline Com orientação, no trabalho & 6,6 & 7,1 & 8,4 \\
\hline Com ajuda de amigos & 15,7 & 13,0 & 7,5 \\
\hline Em cursos especializados & 55,2 & 60,7 & 61,7 \\
\hline De outra maneira & 3,8 & 2,6 & 6,6 \\
\hline Total & 100 & 100 & 100 \\
\hline
\end{tabular}

O processador de texto é o mais utilizado dos programas, seguido de jogos e planilhas eletrônicas, como mostra a tabela abaixo: 
Tabela 3.2.2: Tipos de programas mais utilizados, por tipo de favela

\begin{tabular}{|c|c|c|c|}
\hline & Favelas Altas & Favelas Médias & Favelas Baixas \\
\hline \multicolumn{4}{|l|}{ Tipo de programa } \\
\hline Processadores de texto & 74,9 & 75,2 & 83,9 \\
\hline Planilhas eletrônicas & 48,5 & 40,4 & 61,2 \\
\hline Programas de apres. gráfica & 27,2 & 26,4 & 41,3 \\
\hline Linguagens de programação & 3,8 & 3,7 & 8,7 \\
\hline Jogos & 54,6 & 45,2 & 66,1 \\
\hline Outro & 4,6 & 5,9 & 5,1 \\
\hline
\end{tabular}

Mais de um terço dos usuários de Internet em todas as favelas pretendem fazer cursos a traves da Internet.

Gráfico 3.2.17: Predisposição para realização de curso pela Internet, entre os moradores usuários de microcomputador, por classe de favela

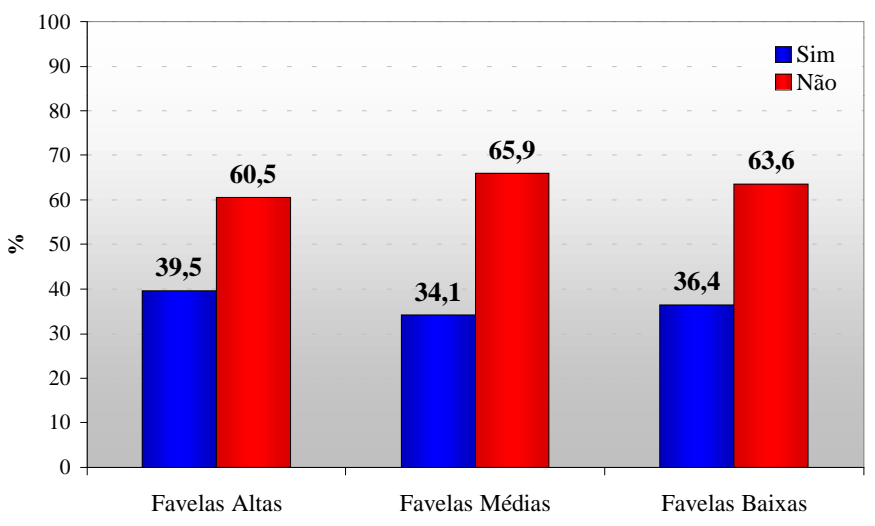

$\mathrm{Na}$ medida em que a renda diminui, muda a forma de aquisição do computador, pelos dos moradores das favelas. Nas favelas de renda média mais baixa, são maiores os índices de compras a prazo e de doações. Entre aqueles que compraram, o padrão tende a ser bastante similar nos diversos tipos de favelas, $70 \%$ comprou um computador novo e $30 \%$ usado. 
Gráfico 3.2.18: Tipo de aquisição do microcomputador do domicílio, por classe de favela

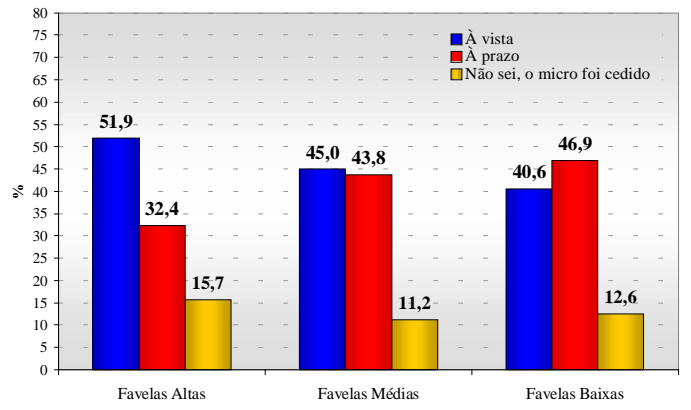

Gráfico 3.2.19: Estado do microcomputador na aquisição, por classe de favela

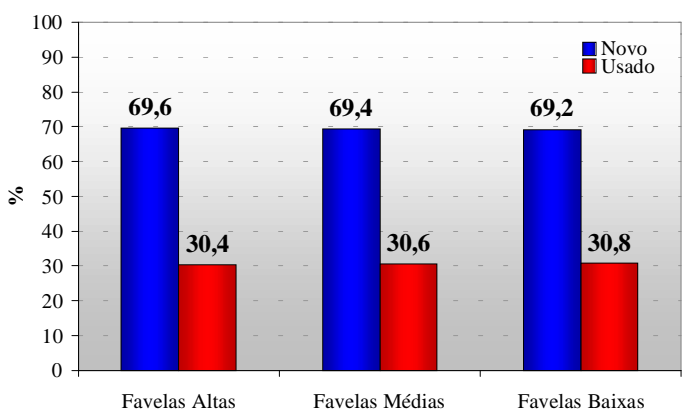

As formas de manutenção/conserto são bastante diversificadas, como se pode constatar na tabela abaixo. Nas favelas baixas, o fato de haver um percentual maior de usuários desse tipo de serviço, fora da favela, está possivelmente relacionado à existência de poucos serviços técnicos dentro dessas favelas.

Tabela 3.2.3: Local de manutenção/conserto do microcomputador, por tipo de favela

\begin{tabular}{|c|c|c|c|}
\hline & Favelas Altas & Favelas Médias & Favelas Baixas \\
\hline \multicolumn{4}{|l|}{ Tipo de local } \\
\hline Locais especializados, fora da comunidade & 10,6 & 7,2 & 20,3 \\
\hline Locais especializados dentro da comunidade & 20,4 & 10,6 & 4,9 \\
\hline Manutenção por parentes /amigos, pago & 17,7 & 13,9 & 18,9 \\
\hline Manutenção por parentes /amigos, gratuita & 23,0 & 30,0 & 21,0 \\
\hline Eu mesmo faço manutenção do meu micro & 15,0 & 22,8 & 19,6 \\
\hline Não faço manutenção & 13,3 & 15,6 & 15,4 \\
\hline Total & 100 & 100 & 100 \\
\hline
\end{tabular}

O gráfico seguinte, no qual foi possível indicar mais de uma alternativa, mostra que os principais usuários dos computadores são os filhos, em particular nas favelas baixas, e mostra também a importância de pessoas não residentes no domicilio, entre os usuários do computador. 
Tabela 3.2.4: Relação do principal usuário do microcomputador com o chefe do domicílio

\begin{tabular}{lcccc}
\hline \hline & & & & \\
\cline { 2 - 2 } Posição no domicílio & & & & \\
Chefe do domicílio & 26,8 & & 25,1 & \\
Cônjuge & 7,1 & & 12,0 & 30,9 \\
Filhos & 37,5 & & 30,1 & 8,7 \\
Outros parentes que moram no domicílio & 7,1 & 12,6 & 62,4 \\
Outros parentes que não moram no domicílio & - & 1,6 & 7,4 \\
Outros & 31,3 & 25,1 & - \\
\hline
\end{tabular}

Como mostra o gráfico abaixo, entre os usuários de computador nas favelas altas, $67.7 \%$ utilizam a Internet, percentual que cai para 56.2\% nas favelas médias, e sobe um pouco, para $59.3 \%$, nas favelas baixas.

Gráfico 3.2.20: Utilização da Internet entre os usuários de computador, por classe de favela

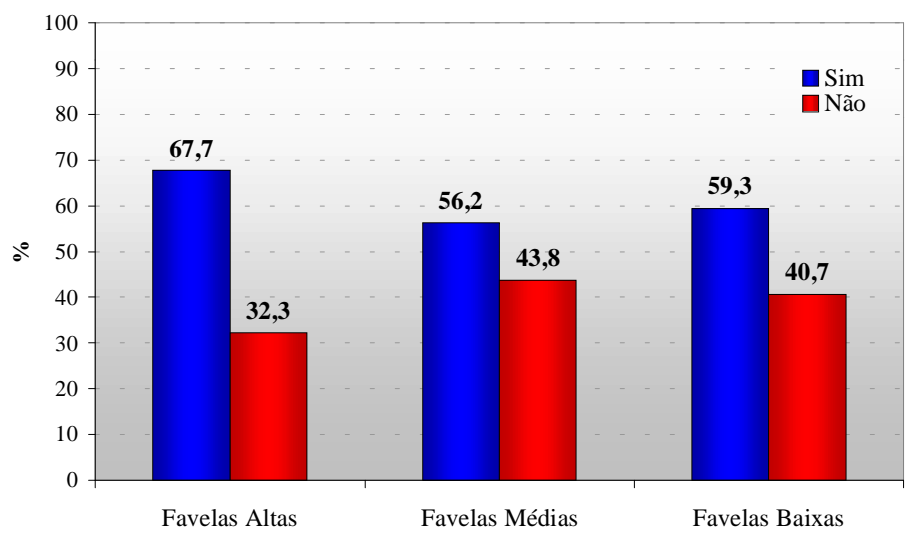

No gráfico a seguir, pode-se observar que a periodicidade do uso da Internet se modifica significativamente, segundo o tipo de favela. Os que a utilizam diariamente, nas favelas altas, são em torno de $26 \%$, enquanto nas favelas médias esse percentual chega a aproximadamente $47 \%$. Já nas favelas baixas, a frequiência de utilização diária da Internet atinge cerca de $18 \%$ dos usuários. Não encontramos uma explicação clara para tal fenômeno. 
Gráfico 3.2.21: Frequiência de utilização da Internet, por classe de favela

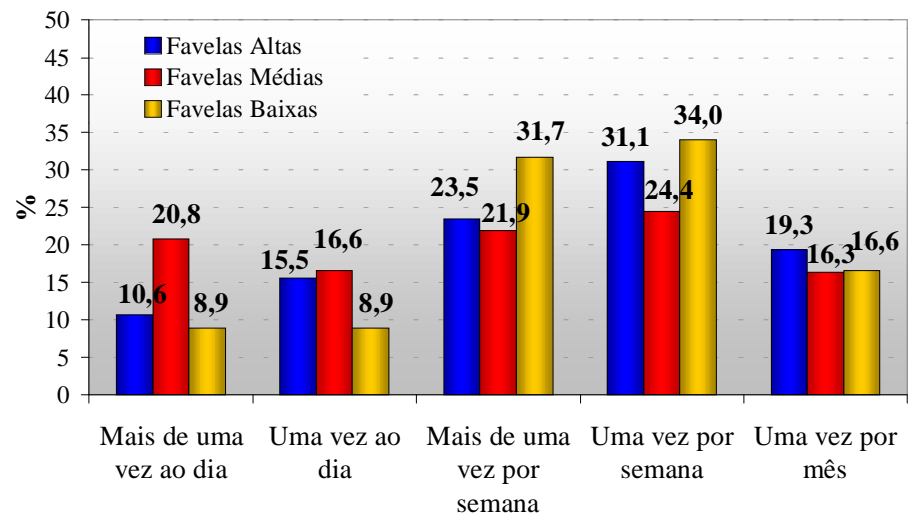

O gráfico a seguir indica as razões para não usar a Internet, explicitadas pelos usuários de computador. A principal delas é não possuir local de acesso. Nas favelas baixas, o custo e a falta de tempo são a segunda razão, enquanto nas favelas altas e baixas, a falta de interesse e achar muito complicado são outros fatores relevantes.

Tabela 3.2.5: Motivos para não utilizar a Internet, por tipo de favela

\begin{tabular}{|c|c|c|c|}
\hline & Favelas Altas & Favelas Médias & Favelas Baixas \\
\hline \multicolumn{4}{|l|}{ Motivo } \\
\hline Não possui local onde possa acessar & 66,1 & 63,4 & 61,5 \\
\hline Não possui interesse & 11,8 & 11,8 & 9,5 \\
\hline Acha muito complicado & 8,7 & 11,5 & 5,0 \\
\hline Caro & 3,9 & 5,4 & 11,2 \\
\hline Não tem tempo & 9,4 & 7,9 & 12,8 \\
\hline Total & 100 & 100 & 100 \\
\hline
\end{tabular}

No próximo gráfico, aparecem os tipos de site acessados. As variações entre os sites é relativamente pequena, predominando, os sites de busca/pesquisa, seguidos dos sites de música, provedores, jornais, webmail, esporte e utilidade pública (não foi incluída a categoria pornografia no elenco de opções estando, portanto, implícita em outros). 
Tabela 3.2.6: Tipos de sites mais acessados, por tipo de favela

\begin{tabular}{|c|c|c|c|c|}
\hline & Favelas Altas & Favelas Médias & Favelas Baixas & Todas as favelas \\
\hline \multicolumn{5}{|l|}{ Tipos de sites } \\
\hline Webmail & 38,8 & 36,9 & 35,4 & 37,0 \\
\hline Lojas virtuais & 14,4 & 11,5 & 11,3 & 12,3 \\
\hline Sites de provedor & 49,4 & 52,5 & 43,6 & 49,0 \\
\hline Sites de busca/ pesquisa & 74,1 & 63,9 & 69,3 & 68,5 \\
\hline Sites de revistas & 33,1 & 31,7 & 24,9 & 30,1 \\
\hline Sites de jornais & 38,8 & 39,3 & 38,9 & 39,1 \\
\hline Utilidade pública & 20,2 & 27,9 & 41,2 & 29,5 \\
\hline Sites de empresas & 17,5 & 20,5 & 25,7 & 21,1 \\
\hline Sites de músicas & 55,5 & 47,0 & 47,1 & 49,5 \\
\hline Sites de esportes & 39,5 & 35,8 & 30,4 & 35,3 \\
\hline Sites infantis & 8,7 & 8,5 & 7,4 & 8,2 \\
\hline Outros tipos de sites (específicos) & 11,8 & 17,8 & 4,3 & 12,1 \\
\hline
\end{tabular}

O gráfico a seguir é, aparentemente, difícil de explicar: enquanto nas favelas altas e baixas, os usuários de Internet utilizam $29.2 \%$ e $25.9 \%$ de provedores pagos, esse percentual salta para 50.8\%, nas favelas médias. A explicação pode estar na amostra de usuários de Internet em domicilio que, sendo muito pequena, a margem de erro técnico aumenta muito. Outro fator pode ser a utilização de "gatos" de serviço de TV a cabo, que incluem um pagamento de "manutenção" ao responsável pelo "gato".

Gráfico 3.2.22: Tipo de provedor utilizado pelos moradores que possuem microcomputador, por classe de favela

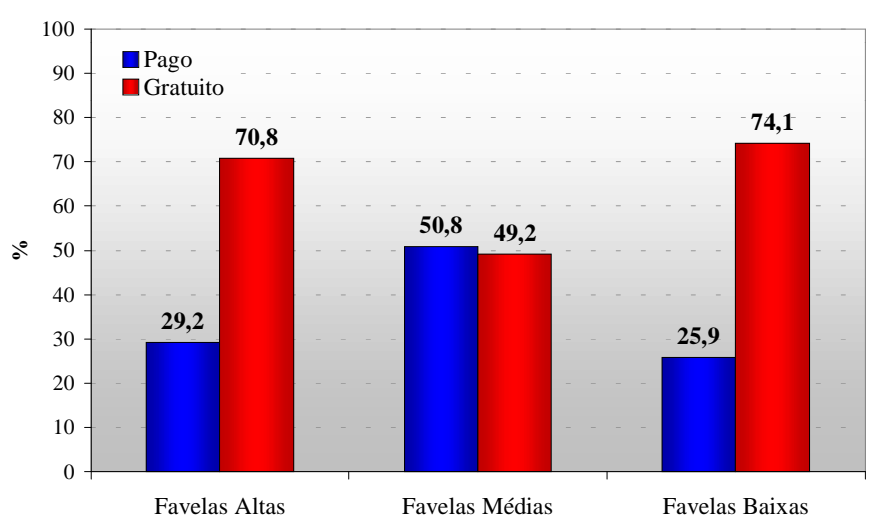


A utilização da Internet para realizar qualquer tipo de negócio é mais freqüente nas favelas altas do que nas médias, e menos freqüente ainda, nas baixas:

Gráfico 3.2.23: Utilização da Internet para fazer negócios, entre os moradores usuários de microcomputador, por classe de favela

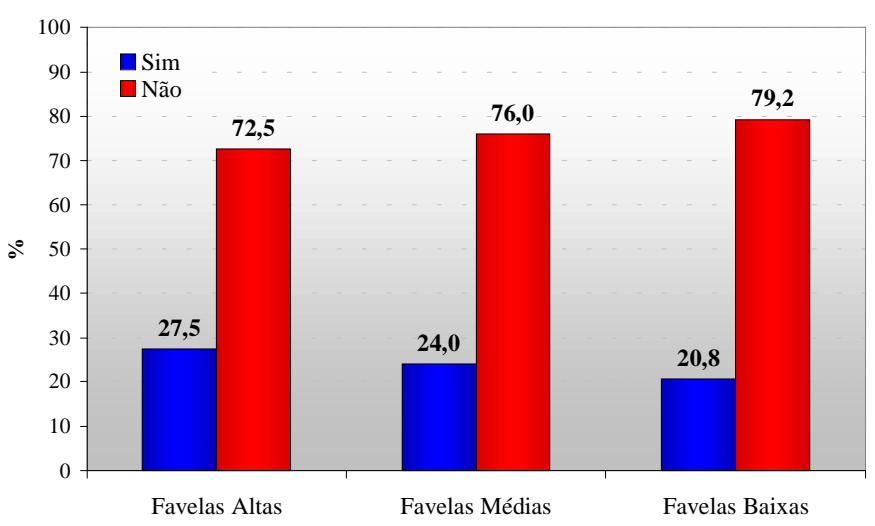

Embora o universo de usuários seja muito pequeno e, portanto, os valores a seguir talvez não sejam estatisticamente representativos, apresentamos a tabela, para dar uma noção dos tipos de transação realizados.

Tabela 3.2.7: Tipos de negócio realizados na Internet, segundo a classe de favela

\begin{tabular}{|c|c|c|c|}
\hline & Favelas Altas & Favelas Médias & Favelas Baixas \\
\hline \multicolumn{4}{|l|}{ Tipo de Negócio } \\
\hline Compra & 28,8 & 45,3 & 48,2 \\
\hline Venda & 4,1 & 7,0 & 12,5 \\
\hline Informação de preços & 27,4 & 12,8 & 16,1 \\
\hline Pagamento de contas & 13,7 & 16,3 & 10,7 \\
\hline Movimentação bancária & 6,8 & 14,0 & 5,4 \\
\hline Outros & 19,2 & 4,7 & 7,1 \\
\hline Total & 100 & 100 & 100 \\
\hline
\end{tabular}

Nas favelas altas, um percentual de usuários maior do que nas favelas médias e baixas acessa sites em outras línguas, refletindo o nível de escolaridade mais alto dessas pessoas. 
Gráfico 3.2.24: Acesso a sites de texto em outras línguas, entre moradores que utilizam microcomputador, por classe de favela

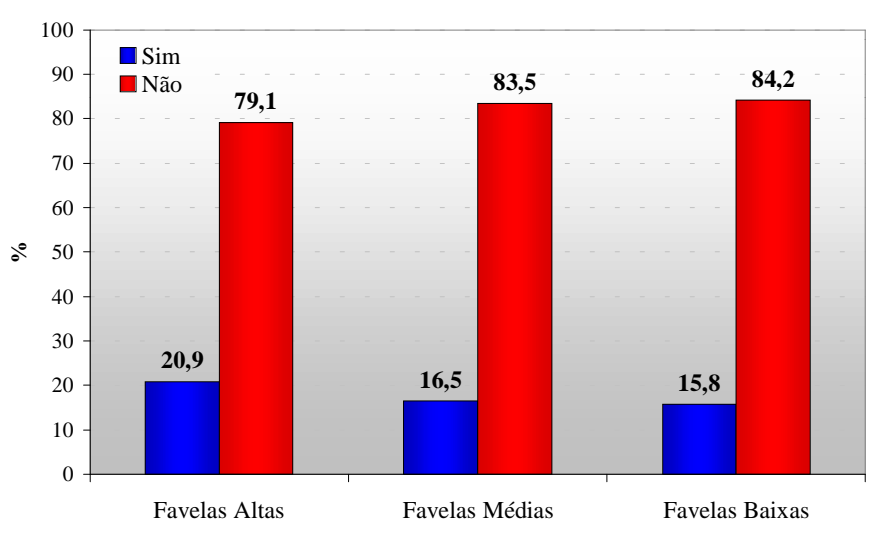

Embora o universo de usuários seja muito pequeno e, portanto, os valores a seguir possivelmente não sejam estatisticamente representativos, apresentamos o gráfico para dar uma noção da aprendizagem de línguas pelos usuários de Internet, nas favelas.

Tabela 3.2.8: Como aprendeu outras línguas, segundo o tipo de favela

\begin{tabular}{|c|c|c|c|}
\hline & Favelas Altas & Favelas Médias & Favelas Baixas \\
\hline Curso & 39,6 & 54,7 & 31,6 \\
\hline Escola & 41,7 & 18,9 & 44,7 \\
\hline Sozinho & 8,3 & 11,3 & 15,8 \\
\hline Na própria Internet & 4,2 & 7,5 & 2,6 \\
\hline De outra maneira & 6,3 & 7,5 & 5,3 \\
\hline Total & 100 & 100 & 100 \\
\hline
\end{tabular}

Quanto à pergunta sobre o interesse dos entrevistados em contatar pessoas de outros países pela Internet, as respostas obtidas foram, na grande maioria, positivas, como demonstra o quadro abaixo. 
Gráfico 3.2.25: Interesse em contatar pessoas de outros países pela Internet, entre os usuários de microcomputador, por classe de favela

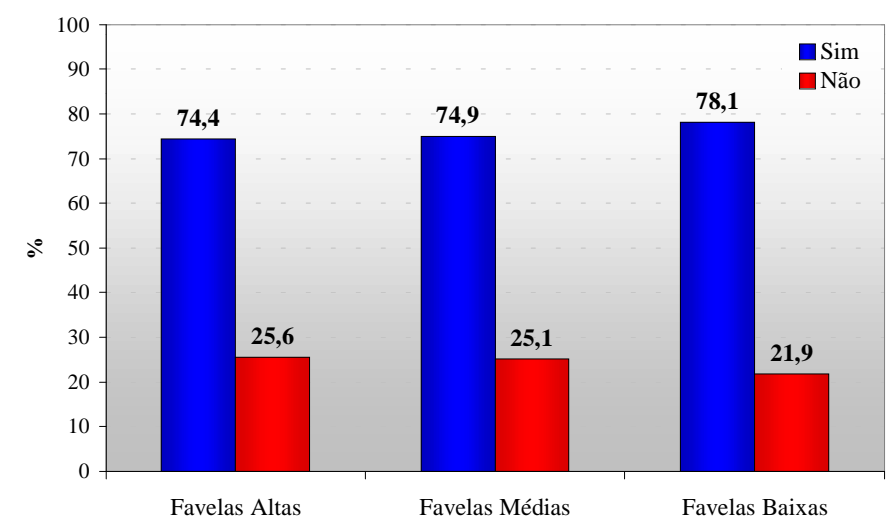

A porcentagem de usuários de e-mails é mais alta nas favelas médias e baixas, do que nas favelas altas. A razão disso se deve ao maior percentual de usuários de Internet nas favelas altas.

Gráfico 3.2.26: Utilização de e-mail entre moradores que usam a Internet, por classe de favela

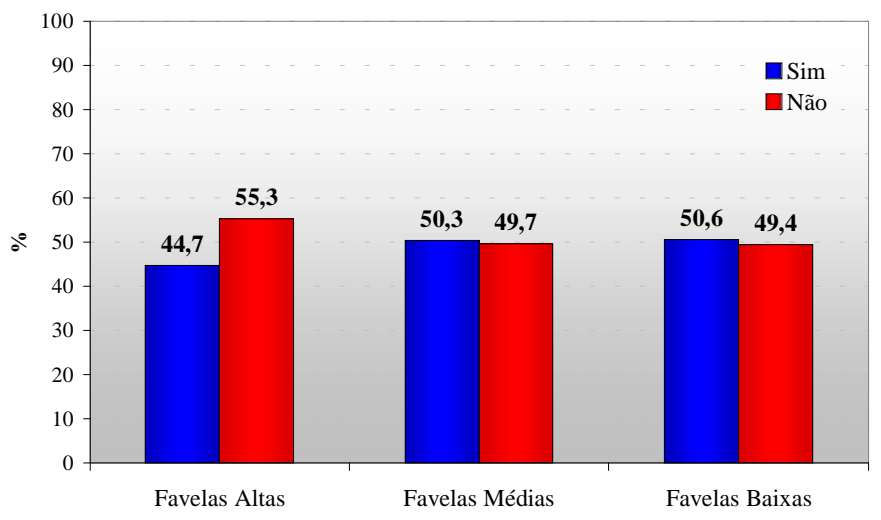

A frequiência com que as pessoas verificam seus e-mails é bastante similar, nos 3 tipos de favelas, com uma freqüência menor nas favelas baixas. Chama a atenção o alto percentual de usuários que verifica e-mails mais de uma vez por dia, nas favelas médias. 
Tabela 3.2.8: Frequiência com que o usuário verifica seu e-mail, por tipo de favela

\begin{tabular}{|c|c|c|c|}
\hline & Favelas Altas & Favelas Médias & Favelas Baixas \\
\hline \multicolumn{4}{|l|}{ Frequencia } \\
\hline Mais de 1 vez ao dia & 16,1 & 20,1 & 8,3 \\
\hline Uma vez ao dia & 17,8 & 29,3 & 15,8 \\
\hline Mais de 1 vez por semana & 21,2 & 17,4 & 28,6 \\
\hline Uma vez por semana & 28,0 & 19,0 & 32,3 \\
\hline Uma vez ao mês & 11,0 & 9,2 & 9,8 \\
\hline Nunca & 5,9 & 4,9 & 5,3 \\
\hline Total & 100 & 100 & 100 \\
\hline
\end{tabular}

Quanto ao percentual de pessoas que fazem parte da lista de e-mails dos usuários, é de 25.1 nas favelas altas, caindo para 20.2 nas favelas médias, e 18.9 nas favelas baixas. $\mathrm{Na}$ medida em que a porcentagem de usuários de Internet na comunidade cai, é natural que o universo de pessoas conhecidas pelo usuário com acesso à Internet também caia.

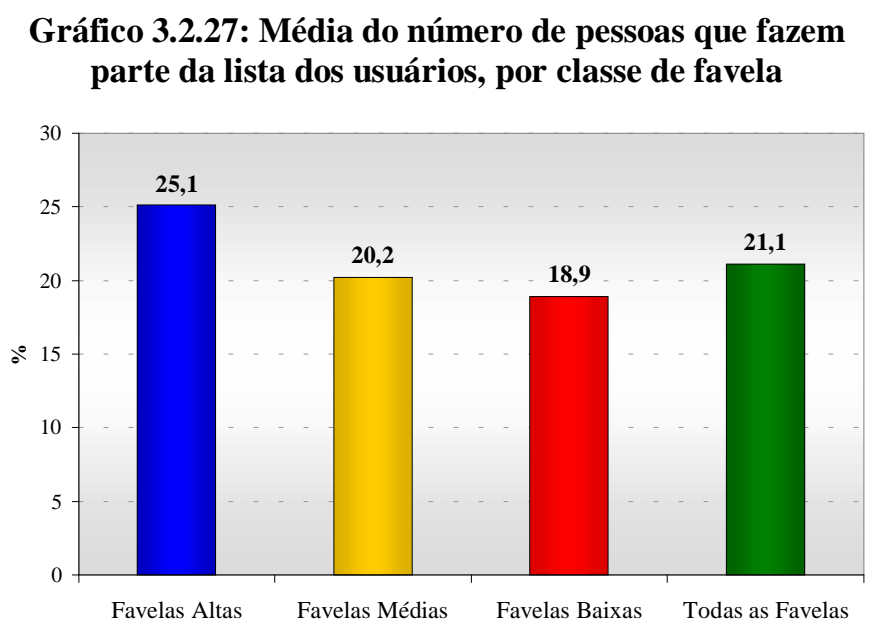

Entre os usuários de e-mail, em torno da metade indicou que conheceu novas pessoas pela Internet, sendo que a porcentagem diminui na medida em que passamos das favelas altas para as baixas. 
Gráfico 3.2.28: Conhecimento de pessoas pela Internet, entre os usuários de microcomputador, por classe de favela

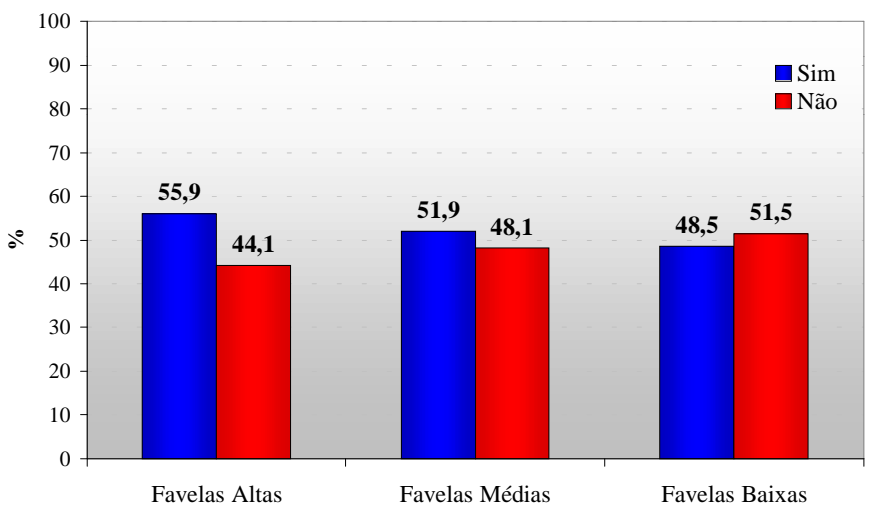

O uso da Internet permite entrar em contato com pessoas de nível socioeconômico mais alto que o do usuário (praticamente a metade) ou equivalente (a outra metade). $\mathrm{O}$ percentual de contato com pessoas de nível mais baixo é irrelevante. Tais resultados estão no gráfico a seguir:

Gráficos 3.2.29: Nível socioeconômico das pessoas contatadas pela Internet, entre usuários de microcomputador, por classe de favela

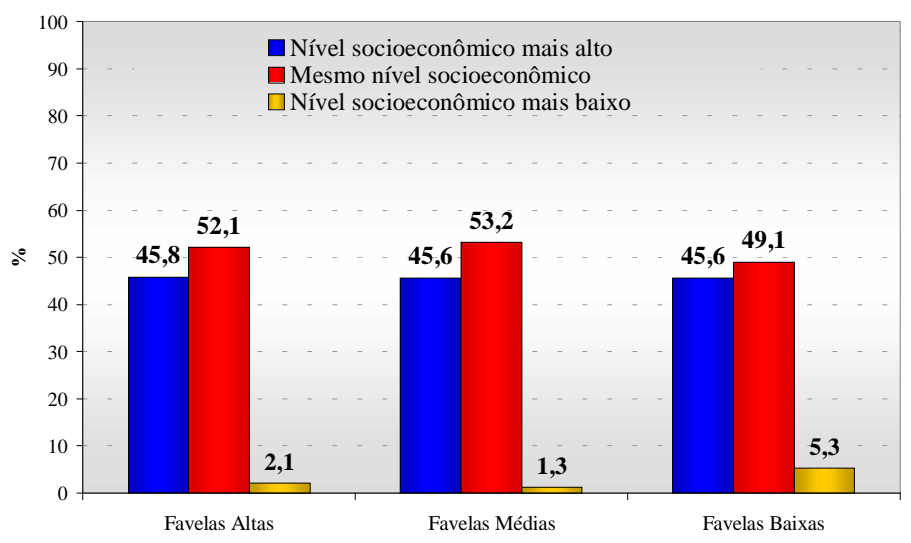

Os contatos feitos via Internet foram relevantes principalmente para a obtenção de informações relativas à própria Internet e em segundo lugar para indicações de trabalho. Cerca de metade desses contatos não tiveram utilidade. 
Tabela 3.2.9: De que maneira as pessoas que você conheceu pela Internet o ajudaram?

\section{Tipo de ajuda}

Favelas Altas $\quad$ Favelas Médias $\quad$ Favelas Baixas

Indicações para trabalho

Na obtenção de inf. s/ temas de seu interesse

Essas pessoas me ajudaram em outras coisas

38,1

10,6

8,9

Essas pessoas não me ajudaram em nada

7,9

27,7

44,6

7,4

5,4

Total 100

54,3

41,1

100
100

A participação em sites de chats é relativamente freqüente entre os usuários de Internet, chegando a $46.7 \%$ nas favelas médias, e caindo para $28.8 \%$ nas favelas baixas

Gráfico 3.2.30: Participação em chats, entre moradores usuários da Internet, por classe de favela

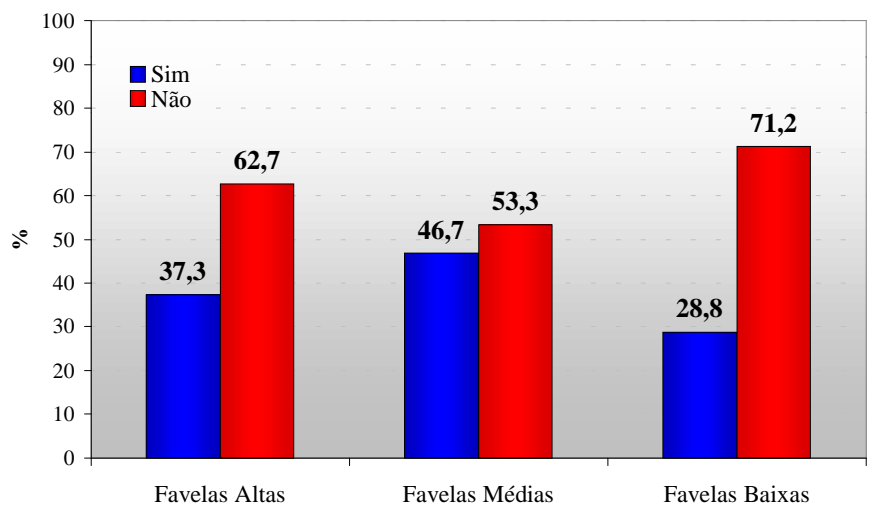

Enquanto nas favelas altas, os usuários que utilizam o e-mail para trabalho (inclusive escolar) e lazer superam os $50 \%$, nas favelas médias e baixas essa porcentagem cai para pouco mais de $40 \%$. A utilização somente para trabalho é maior nas favelas médias, porém, se somarmos os resultados das duas opções - "somente para trabalho" e "mais para trabalho do que para lazer" - nas favelas baixas será obtido um total de $40.8 \%$ e, nas favelas médias e altas, totais em torno de $30 \%$. 
Tabela 3.2.10: Objetivo da utilização do e-mail, por tipo de favela

\begin{tabular}{|c|c|c|c|}
\hline & Favelas Altas & Favelas Médias & Favelas Baixas \\
\hline \multicolumn{4}{|l|}{ Motivo } \\
\hline Somente para trabalho & 15,5 & 11,9 & 21,4 \\
\hline Mais $\mathrm{p} /$ trabalho que $\mathrm{p} /$ lazer & 14,1 & 20,6 & 19,4 \\
\hline Metade $\mathrm{p} /$ trabalho metade $\mathrm{p} /$ lazer & 52,1 & 41,3 & 40,8 \\
\hline Mais $p$ / lazer do que $p /$ trabalho & 18,3 & 26,2 & 18,4 \\
\hline Total & 100 & 100 & 100 \\
\hline
\end{tabular}

Praticamente todos os usuários de informática consideram que saber computação ajuda a encontrar emprego.

Gráfico 3.2.31: Opinião sobre a importância do domínio de computação na conquista de emprego, entre usuários de microcomputador, por classe de favela

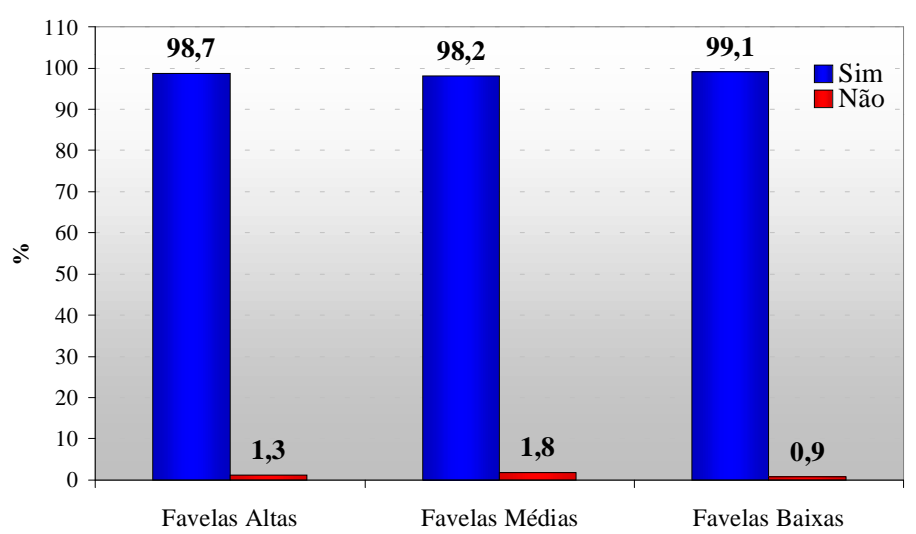

Entre os que conseguiram emprego com ajuda da informática (cerca de 1/3 dos usuários de computador) mais da metade assinalou que o conhecimento de informática era condição para a obtenção de emprego. Já $18.4 \%$, nas favelas médias, e $32.7 \%$ nas favelas baixas indicaram que tal conhecimento ajudou na hora da entrevista e, embora não fosse condição essencial para obtenção do emprego, aumentava o interesse do empregador. Além disso, $16.9 \%$ desse universo nas favelas altas, e $12.3 \%$ nas favelas baixas obtiveram na Internet informações sobre o emprego. 
Tabela 3.2.11: Como a informática ajudou a conseguir emprego por tipo de favela

\begin{tabular}{|c|c|c|c|}
\hline & Favelas Altas & Favelas Médias & Favelas Baixas \\
\hline \multicolumn{4}{|l|}{ Contribuição da computação } \\
\hline Através de informações & 16,9 & 14,7 & 12,3 \\
\hline Na hora da entrevista & 22,9 & 18,4 & 32,7 \\
\hline Exigência do trabalho & 58,5 & 64,5 & 51,2 \\
\hline Outros motivos & 1,7 & 2,3 & 3,7 \\
\hline
\end{tabular}

\section{3 - Diferenças por gênero ${ }^{8}$}

Como vimos anteriormente, a porcentagem da população feminina que utiliza o computador é inferior à da população masculina. Também em relação à intensidade do uso do computador, a população feminina é desfavorecida. Essa desigualdade só diminui nas favelas baixas, possivelmente devido à relevância da população escolar, na qual não se observam diferenças significativas entre os gêneros, quanto ao uso da informática.

Tabela 3.3.1: Freqüência de utilização do computador, por tipo de favela e sexo

\begin{tabular}{|c|c|c|c|c|c|c|}
\hline & \multicolumn{2}{|c|}{ Favelas Altas } & \multicolumn{2}{|c|}{$\begin{array}{l}\text { Favelas Médias } \\
\end{array}$} & \multicolumn{2}{|c|}{ Favelas Baixas } \\
\hline & Masculino & Feminino & Masculino & Feminino & Masculino & Feminino \\
\hline Diariamente & 29,0 & 28,0 & 38,0 & 22,9 & 29,5 & 25,4 \\
\hline Pelo menos uma vez por semana & 32,5 & 24,4 & 24,9 & 28,1 & 26,7 & 27,1 \\
\hline Utiliza eventualmente & 13,0 & 13,4 & 15,0 & 15,6 & 12,8 & 8,3 \\
\hline Utiliza raramente & 25,5 & 34,1 & 22,2 & 33,3 & 31,0 & 39,2 \\
\hline Total & 100 & 100 & 100 & 100 & 100 & 100 \\
\hline
\end{tabular}

\footnotetext{
${ }^{8}$ Todas as tabelas desta seção mostram percentuais relativos ao próprio grupo.
} 
Como indicamos anteriormente, nos setores pobres da população a aprendizagem por "osmose" - isto é, aprender vendo os pais usar o micro ou simplesmente brincar com o computador - muito comum na classe média, é bastante reduzida. Nesses setores, os cursos especializados são o principal caminho de aprendizagem em gral e, em particular, para os usuários do sexo feminino. A aprendizagem com a ajuda de amigos ou sozinho é muito mais freqüente entre os usuários do sexo masculino. O trabalho, embora importante local de acesso, é muito menos relevante como local de aprendizagem.

Tabela 3.3.2: Como aprendeu a usar o computador, por tipo de favela e sexo

\begin{tabular}{|c|c|c|c|c|c|c|}
\hline \multirow[b]{3}{*}{ Sozinho, por tentativas } & \multicolumn{2}{|c|}{ Favelas Altas } & \multicolumn{2}{|c|}{ Favelas Médias } & \multicolumn{2}{|c|}{ Favelas Baixas } \\
\hline & Masculino & Feminino & Masculino & Feminino & Masculino & Feminino \\
\hline & 18,7 & 14,6 & 18,4 & 11,9 & 15,0 & 9,7 \\
\hline Sozinho, c/ ajuda de manuais & 2,6 & 0,6 & 1,4 & 0,7 & 3,8 & 1,6 \\
\hline Com orientação, no trabalho & 5,7 & 7,9 & 7,5 & 6,7 & 12,0 & 3,2 \\
\hline Com ajuda de amigos & 18,7 & 11,6 & 17,3 & 7,4 & 9,0 & 5,4 \\
\hline Em cursos especializados & 49,6 & 62,8 & 53,2 & 70,2 & 53,4 & 73,5 \\
\hline De outra maneira & 4,8 & 2,4 & 2,2 & 3,2 & 6,8 & 6,5 \\
\hline Total & 100 & 100 & 100 & 100 & 100 & 100 \\
\hline
\end{tabular}

Entre os gêneros, a principal diferença na utilização de programas da Internet se refere aos jogos, mais utilizados pelo público masculino, em particular nas favelas altas e médias.

Tabela 3.3.3: Tipos de programas mais utilizados, por sexo e classe de favela

\begin{tabular}{|c|c|c|c|c|c|c|}
\hline & \multicolumn{2}{|c|}{ Favelas Altas } & \multicolumn{2}{|c|}{ Favelas Médias } & \multicolumn{2}{|c|}{ Favelas Baixas } \\
\hline & Masculino & Feminino & Masculino & Feminino & Masculino & Feminino \\
\hline Processadores de texto & 74,6 & 75,2 & 70,0 & 81,4 & 77,7 & 93,4 \\
\hline Planilhas eletrônicas & 48,2 & 49,1 & 37,8 & 44,2 & 60,0 & 63,2 \\
\hline Programas de apres. gráfica & 26,3 & 28,6 & 27,8 & 24,9 & 42,6 & 39,6 \\
\hline Linguagens de programação & 4,4 & 3,1 & 5,3 & 1,8 & 9,4 & 7,7 \\
\hline Jogos & 61,0 & 46,0 & 49,4 & 40,4 & 67,9 & 63,7 \\
\hline Outros & 4,4 & 5,0 & 6,9 & 4,6 & 6,4 & 2,7 \\
\hline Total & 100 & 100 & 100 & 100 & 100 & 100 \\
\hline
\end{tabular}

Entre os que utilizam o computador, o universo do usuário do sexo feminino é bastante inferior em todas as favelas, como vemos no gráfico abaixo: 
Gráfico 3.3.1: Utilização da Internet, por classe de favela e sexo

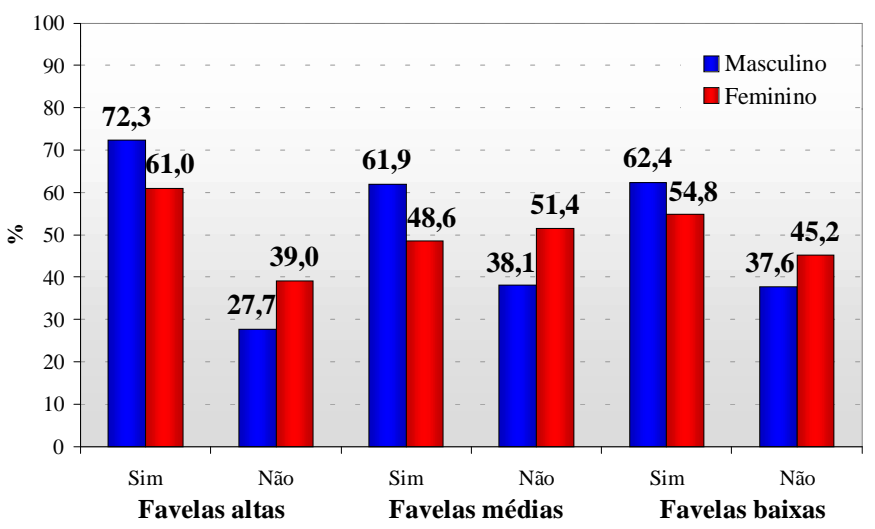

As razões para não acessar a Internet, por parte dos usuários homens e mulheres, apresenta nuanças significativas. A falta de local tem maior importância para o público feminino do que para o masculino, nas favelas médias e altas. Quanto à localização de espaços de Internet, não há diferenças entre os resultados de ambos os gêneros. Isto pode ser explicado pela percepção do espaço de circulação dentro e fora da favela, já que as pessoas do sexo masculino apresentam maior mobilidade e, no caso de menores de idade, os meninos são menos controlados pelos pais. A falta de um maior interesse, indicada pelos homens, merece ser pesquisada.

Tabela 3.3.4: Motivos para não acessar a Internet

\begin{tabular}{|c|c|c|c|c|c|c|}
\hline \multirow[b]{3}{*}{ Não possui local onde acessar } & \multicolumn{2}{|c|}{ Favelas Altas } & \multicolumn{2}{|c|}{ Favelas Médias } & \multicolumn{2}{|c|}{ Favelas Baixas } \\
\hline & Masculino & Feminino & Masculino & Feminino & Masculino & Feminino \\
\hline & 58,7 & 73,4 & 60,4 & 66,2 & 62,5 & 60,2 \\
\hline Não possui interesse & 14,3 & 9,4 & 13,4 & 10,3 & 11,5 & 7,2 \\
\hline Acha muito complicado & 14,3 & 3,1 & 11,9 & 11,0 & 5,2 & 4,8 \\
\hline Caro & 4,8 & 3,1 & 5,2 & 5,5 & 10,4 & 12,0 \\
\hline Não tem tempo & 7,9 & 10,9 & 9,0 & 6,9 & 10,4 & 15,7 \\
\hline Total & 100 & 100 & 100 & 100 & 100 & 100 \\
\hline
\end{tabular}

Somados os que acessam uma vez por dia ou mais, os usuários masculinos apresentam uma porcentagem maior, em particular nas favelas médias e baixas. 
Tabela 3.3.5: Freqüência de acesso à Internet, por classe de favela e sexo

\begin{tabular}{|c|c|c|c|c|c|c|}
\hline & \multicolumn{2}{|c|}{ Favelas Altas } & \multicolumn{2}{|c|}{ Favelas Médias } & \multicolumn{2}{|c|}{ Favelas Baixas } \\
\hline & Masculino & Feminino & Masculino & Feminino & Masculino & $\overline{\text { Feminino }}$ \\
\hline Mais de uma vez ao dia & 9,1 & 13,1 & 24,8 & 13,2 & 9,3 & 8,2 \\
\hline Uma vez ao dia & 17,7 & 12,1 & 17,6 & 15,4 & 10,6 & 6,2 \\
\hline Mais de uma vez por semana & 22,6 & 25,3 & 24,3 & 17,6 & 32,9 & 29,9 \\
\hline Uma vez por semana & 30,5 & 32,3 & 23,0 & 27,2 & 30,4 & 39,2 \\
\hline Uma vez por mês & 20,1 & 17,2 & 10,4 & 26,5 & 16,8 & 16,5 \\
\hline Total & 100 & 100 & $\mathbf{1 0 0}$ & 100 & 100 & 100 \\
\hline
\end{tabular}

No tocante ao tipo de site acessado, as diferenças entre gêneros são bastante sugestivas. Enquanto os sites de esporte se encontram entre os mais acessados pelos homens, são secundários entre as mulheres. Sites de busca/pesquisa, provedor, jornais e música, por sua vez, são acessados igualmente por homens e mulheres. Exceto nas favelas altas, os sites de utilidade pública são bastante acessados, enquanto os de empresas são igualmente acessados em favelas altas e médias, porém em menor proporção por mulheres das favelas baixas.

Tabela 3.3.6: Tipos de sites mais procurados, por sexo e classe de favela

\begin{tabular}{|c|c|c|c|c|c|c|}
\hline \multirow[b]{3}{*}{ Wehmail } & \multicolumn{2}{|c|}{ Eavelas Altas } & \multicolumn{2}{|c|}{ Eavelas Médias } & \multicolumn{2}{|c|}{ Eavelas Baixas } \\
\hline & Masculino & Feminino & Masculino & Feminino & Masculino & Feminino \\
\hline & 40,5 & 35,4 & 38,6 & 33,6 & 38,8 & 30,2 \\
\hline Lojas virtuais & 14,7 & 14,1 & 11,7 & 10,7 & 10,0 & 13,5 \\
\hline Sites de provedor & 49,7 & 49,5 & 50,2 & 55,0 & 40,0 & 50,0 \\
\hline Sites de busca/ pesquisa & 78,5 & 66,7 & 61,0 & 68,6 & 68,8 & 69,8 \\
\hline Sites de revistas & 25,8 & 45,5 & 32,7 & 30,0 & 23,1 & 28,1 \\
\hline Sites de jornais & 40,5 & 36,4 & 41,7 & 35,0 & 42,5 & 33,3 \\
\hline Utilidade pública & 23,9 & 13,1 & 26,9 & 28,6 & 41,3 & 41,7 \\
\hline Sites de empresas & 17,8 & 17,2 & 21,5 & 18,6 & 30,0 & 18,8 \\
\hline Sites de músicas & 59,5 & 49,5 & 50,7 & 41,4 & 48,1 & 44,8 \\
\hline Sites de esportes & 55,8 & 13,1 & 48,0 & 15,0 & 42,5 & 10,4 \\
\hline Sites infantis & 5,5 & 14,1 & 7,6 & 9,3 & 6,9 & 8,3 \\
\hline Outros tipos de sites (específicos) & 11,7 & 12,1 & 20,6 & 13,6 & 3,1 & 6,3 \\
\hline
\end{tabular}

A disposição para fazer cursos pela Internet não é muito diferente entre os sexos, como vemos no gráfico abaixo. 
Gráfico 3.3.2: Predisposição à realização de cursos pela Internet, por sexo e classe de favela

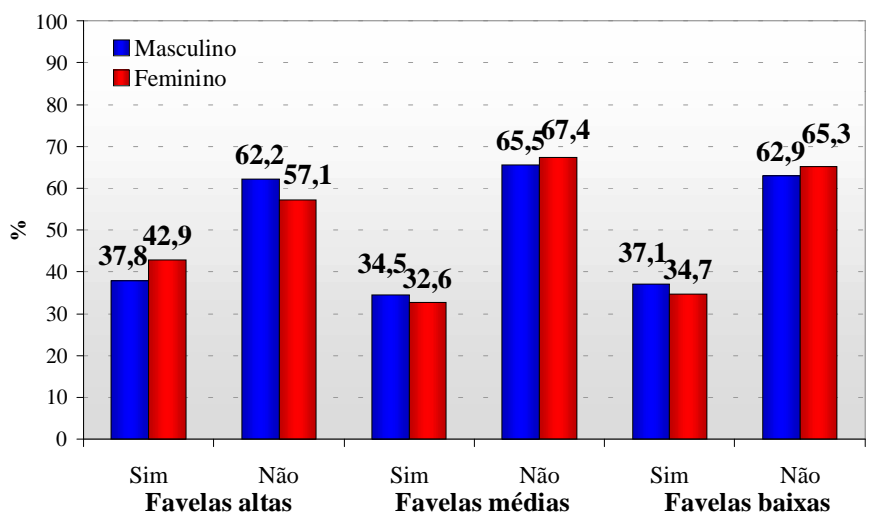

A utilização da Internet para fazer negócios é similar entre os sexos, nas favelas altas, e vai se modificando nas favelas médias e baixas, onde a porcentagem de mulheres que realizam negócios via Internet é bastante inferior.

\section{Gráfico 3.3.3: Utilização da Internet para fazer negócios, por sexo e classe de favela}

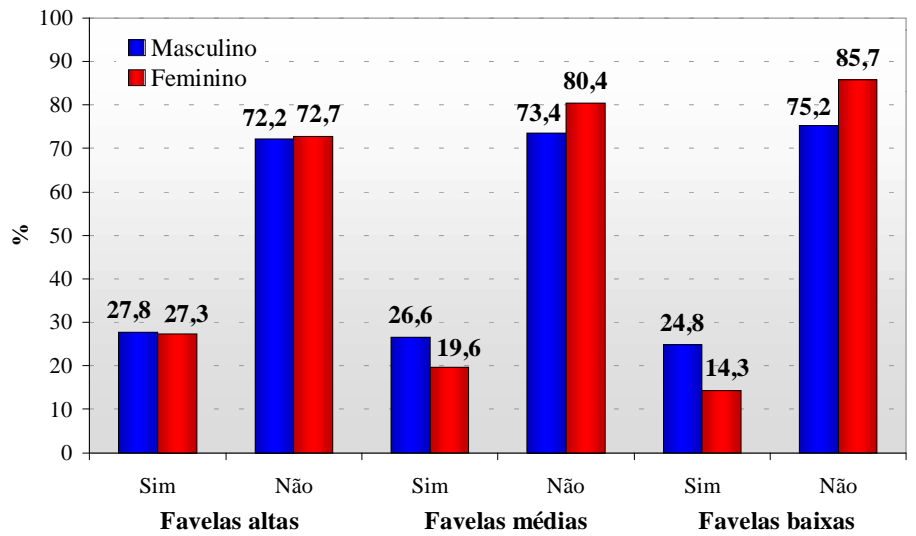

A principal diferença no uso de Internet para realizar negócios, comum aos vários tipos de favelas, é a sua grande utilização para pesquisa de preços, pelas mulheres.

Tabela 3.3.7: Tipos de negócios realizados na Internet, por sexo e classe de favela

\begin{tabular}{|c|c|c|c|c|c|c|}
\hline \multirow[b]{3}{*}{ Compra } & \multicolumn{2}{|c|}{ Favelas Altas } & \multicolumn{2}{|c|}{ Favelas Médias } & \multicolumn{2}{|c|}{ Favelas Baixas } \\
\hline & Pasculino & Feminino & Masculino & Feminino & Masculino & Feminino \\
\hline & 30,4 & 25,9 & 45,8 & 42,3 & 50,0 & 42,9 \\
\hline Venda & 6,5 & 3,7 & 13,6 & 15,4 & 23,8 & - \\
\hline Informação de preços & 32,6 & 40,7 & 13,6 & 23,1 & 28,6 & 35,7 \\
\hline Pagamento de contas & 32,6 & 22,2 & 28,8 & 34,6 & 28,6 & 21,4 \\
\hline Movimentação bancária & 21,7 & 22,2 & 32,2 & 30,8 & 26,2 & 28,6 \\
\hline Outros & 17,4 & 22,2 & 5,1 & 3,8 & 7,1 & 14,3 \\
\hline
\end{tabular}


Enquanto nas favelas altas e médias, os homens acessam mais sites em outras línguas do que as mulheres, nas favelas baixas esta tendência se inverte.

Gráfico 3.3.4: Acesso a sites em outras línguas, por sexo e classe de favela

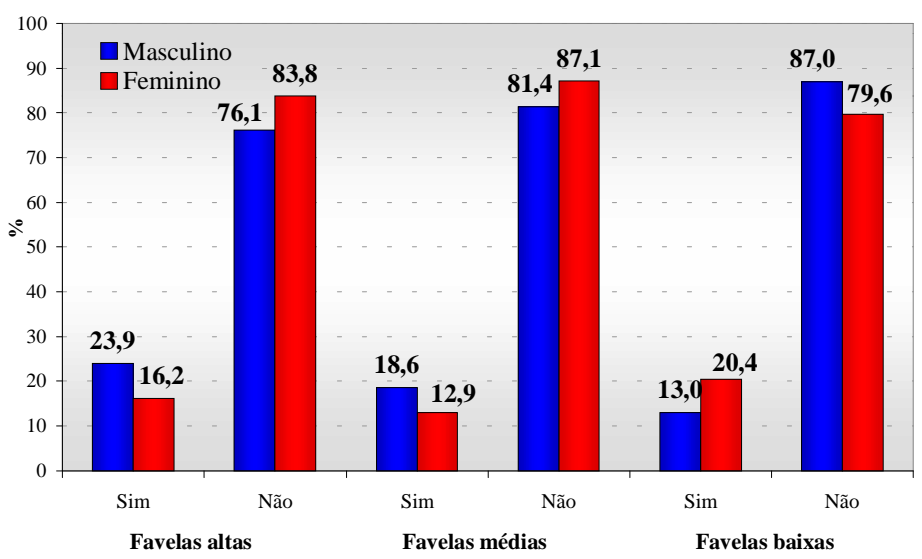

Não há diferenças significativas entre os sexos, quanto ao interesse de entrar em contato com pessoas de outros países.

Gráfico 3.3.5: Interesse em contatar comunidades de outros países, por sexo e classe de favela

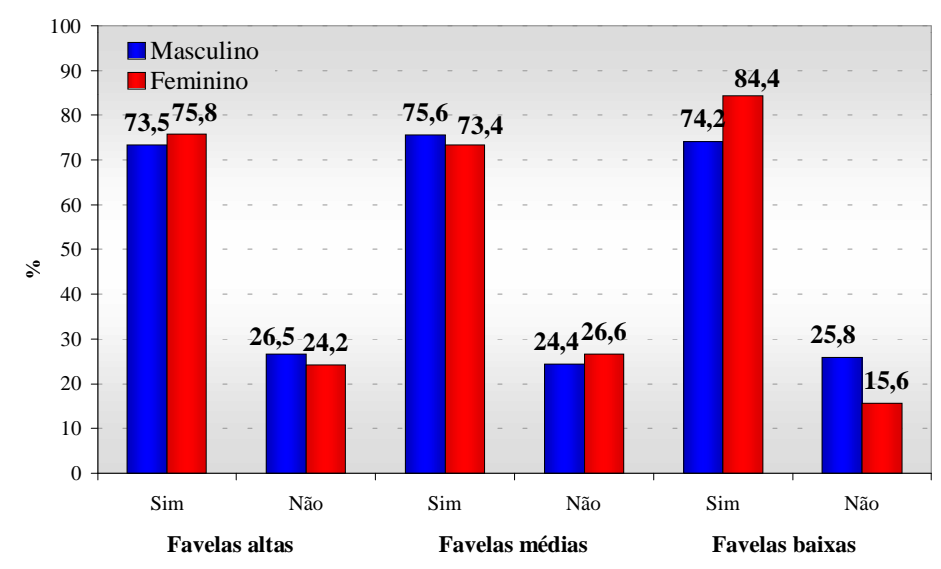

Quanto ao uso de e-mail, os usuários de Internet não apresentaram diferenças significativas, considerado-se o sexo. 
Gráfico 3.3.6: Utilização de e-mail por sexo e classe de favela

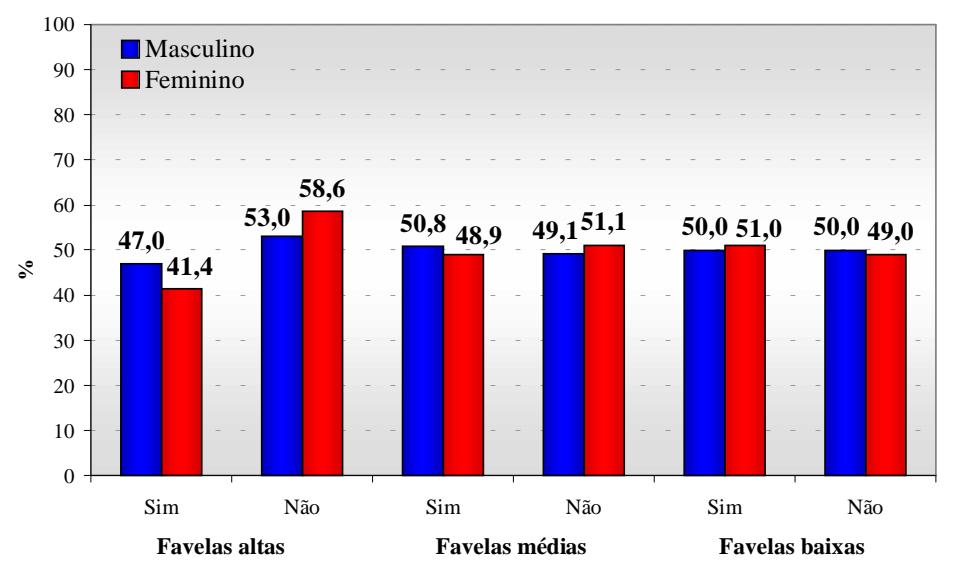

A periodicidade de utilização de e-mails é maior entre as mulheres nas favelas altas, e menor nas favelas médias e baixas.

Tabela 3.3.8: Freqüência de utilização de e-mails, por sexo e tipo de favela

\begin{tabular}{|c|c|c|c|c|c|c|}
\hline \multirow[b]{3}{*}{ Moinda 1 unz oldi } & \multicolumn{2}{|c|}{$\begin{array}{l}\text { Favelas Altas } \\
\end{array}$} & \multicolumn{2}{|c|}{ Favelas Médias } & \multicolumn{2}{|c|}{ Favelas Baixas } \\
\hline & Masculino & Feminino & Masculino & Feminino & Masculino & Feminino \\
\hline & 16,9 & 19,5 & 33,3 & 22,1 & 17,1 & 14,0 \\
\hline Uma vez ao dia & 15,6 & 17,1 & 24,6 & 11,8 & 7,3 & 10,0 \\
\hline Uma vez por semana & 31,2 & 22,0 & 14,0 & 27,9 & 34,1 & 28,0 \\
\hline Mais de 1 vez por semana & 22,1 & 19,5 & 21,1 & 11,8 & 28,0 & 30,0 \\
\hline Uma vez ao mês & 9,1 & 14,6 & 5,3 & 16,2 & 8,5 & 12,0 \\
\hline Nunca & 5,2 & 7,3 & 1,8 & 10,3 & 4,9 & 6,0 \\
\hline
\end{tabular}

O universo de pessoas contatadas através da Internet, entre as mulheres, é bastante inferior ao dos homens. Uma provável razão seria o controle e a vigilância intensos, exercidos sobre o mundo feminino por pais ou esposos.

Gráfico 3.3.7: Média do número de pessoas que fazem parte da lista dos usuários de e-mail, por sexo e classe de favela

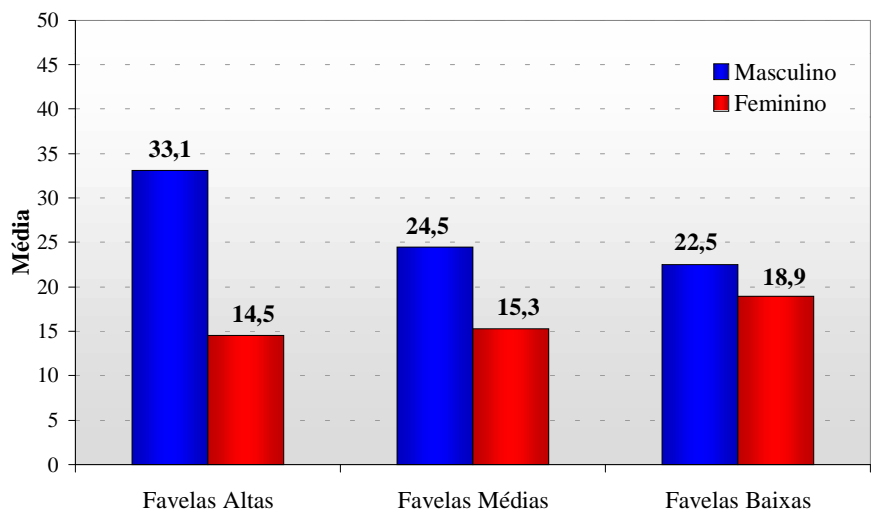


A Internet permite, porém, nivelar o acesso a outras pessoas "virtuais", sendo a porcentagem bastante similar entre homens e mulheres, em particular nas favelas médias e baixas.

Gráfico 3.3.8: Conhecimento de pessoas pela Internet, por sexo e classe de favela

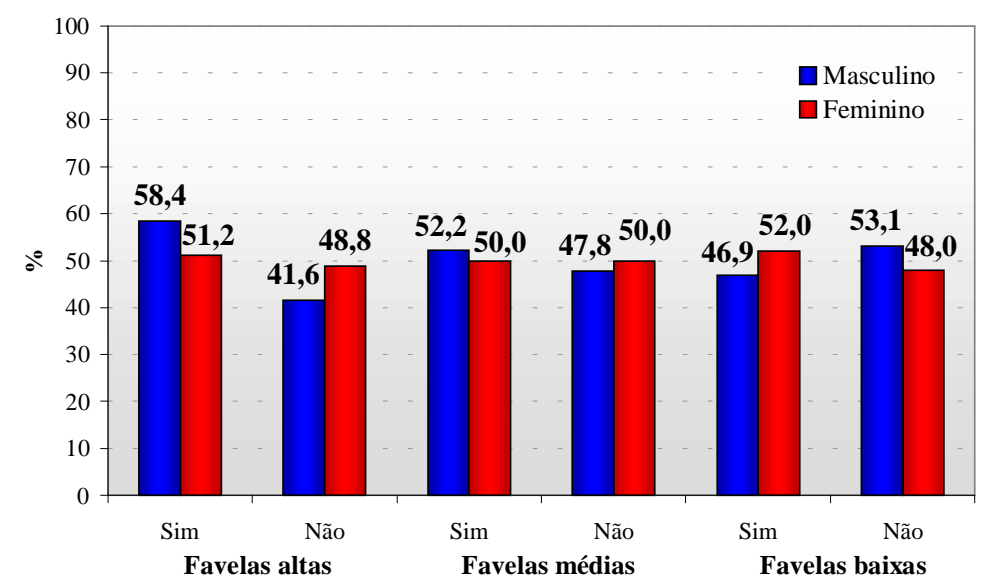

Em geral, tanto homens como mulheres encontram na Internet pessoas de nível socioeconômico mais alto ou igual ao seu, embora nas favelas baixas $9.5 \%$ das mulheres indiquem ter encontrado pessoas de nível inferior.

Gráfico 3.3.9: Nível socioeconômico das pessoas conhecidas através da Internet, por sexo e classe de favela

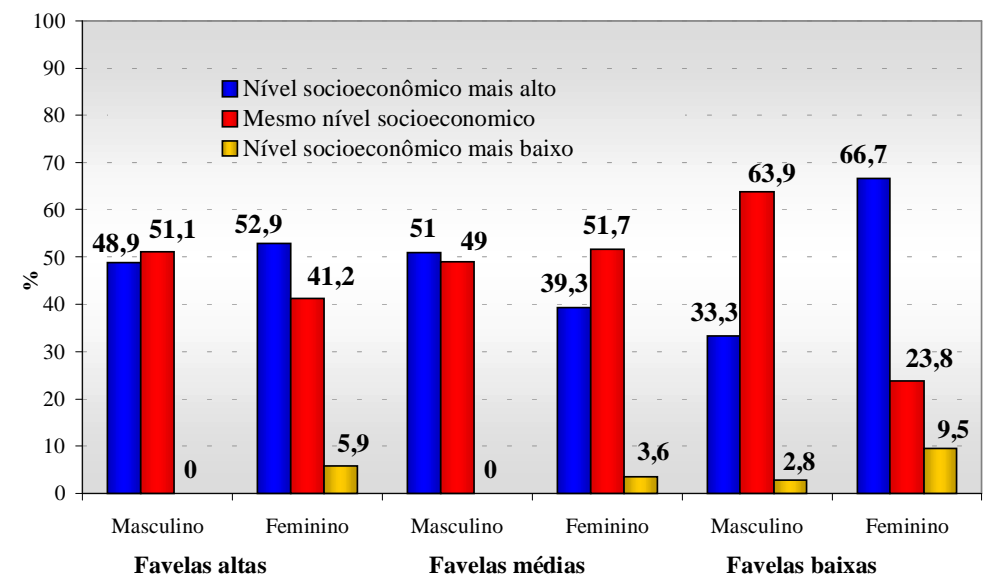

Em geral as mulheres, muito mais do que os homens, acharam que esses contatos não lhes trouxeram qualquer ajuda. Quanto aos demais itens, não houve diferença significativa entre os gêneros. 
Tabela 3.3.9: De que maneira as pessoas conhecidas através da Internet ajudaram você, por sexo

\begin{tabular}{|c|c|c|c|c|c|c|}
\hline & \multicolumn{2}{|c|}{ Favelas } & \multicolumn{2}{|c|}{ Favelas } & \multicolumn{2}{|c|}{ Favelas } \\
\hline & Masculino & Feminino & Masculino & Feminino & Masculino & Feminino \\
\hline Essas pessoas não me ajudaram em nada & 41,9 & 60,0 & 50,8 & 61,8 & 32,4 & 52,2 \\
\hline Na obtenção de inf. s/ temas de meu interesse & 39,5 & 35,0 & 28,8 & 26,5 & 50,0 & 39,1 \\
\hline Essas pessoas me ajudaram em outras coisas & 11,6 & - & 10,2 & 2,9 & 5,9 & 4,3 \\
\hline Indicações para trabalho & 7,0 & 5,0 & 10,2 & 8,8 & 11,8 & 4,3 \\
\hline
\end{tabular}

As mulheres têm uma tendência ligeiramente maior a participar de sites de chats do que os homens, como se vê no gráfico abaixo.

Gráfico 3.3.10: Participação em chats, por sexo e classe de favela

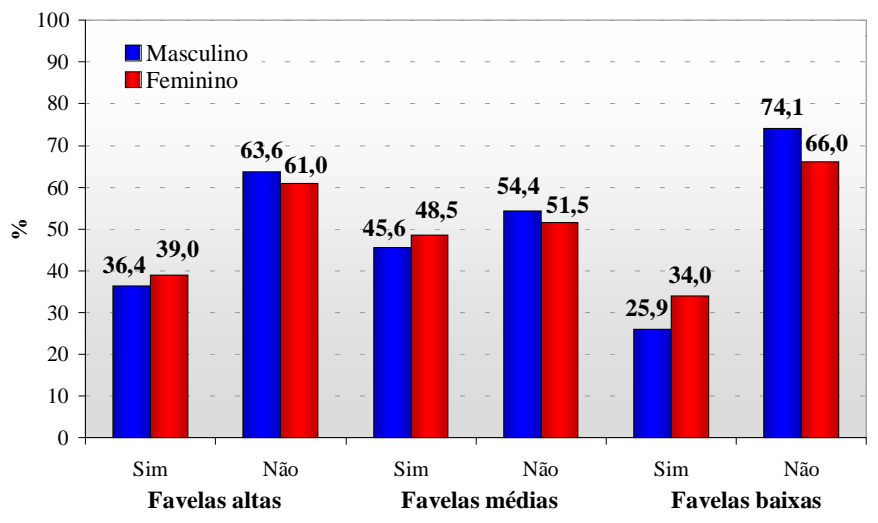

Em particular nas favelas baixas, mas também nas favelas altas, é muito maior o número de mulheres que utilizam o e-mail apenas para trabalho. Já nas favelas médias, a relação se inverte. Isto confirma a hipótese da primeira parte deste livro, onde ressaltamos a importância do trabalho, na discriminação entre mulheres e homens.

Tabela 3.3.10: Objetivo da utilização do e-mail

\begin{tabular}{|c|c|c|c|c|c|c|}
\hline \multirow[b]{3}{*}{ Metade $\mathrm{p} /$ trabalho metade $\mathrm{p} /$ lazer } & \multicolumn{2}{|c|}{ Favelas } & \multicolumn{2}{|c|}{ Favelas } & \multicolumn{2}{|c|}{ Favelas } \\
\hline & Masculino & Feminino & Masculino & Feminino & Masculino & Feminino \\
\hline & 47,1 & 65,0 & 42,7 & 40,8 & 32,8 & 53,8 \\
\hline Mais $\mathrm{p} /$ lazer do que $\mathrm{p} /$ trabalho & 19,6 & 15,0 & 24,0 & 28,6 & 17,2 & 20,5 \\
\hline Somente para trabalho & 17,6 & 10,0 & 9,3 & 16,3 & 32,8 & 2,6 \\
\hline Mais $\mathrm{p} /$ trabalho que $\mathrm{p} /$ lazer & 15,7 & 10,0 & 24,0 & 14,3 & 17,2 & 23,1 \\
\hline
\end{tabular}


Praticamente a totalidade de homens e mulheres indica a importância de saber computação para obter um emprego.

Gráfico 3.3.11: Opinião sobre a importância do domínio de computação na conquista de emprego, por sexo e classe de favela

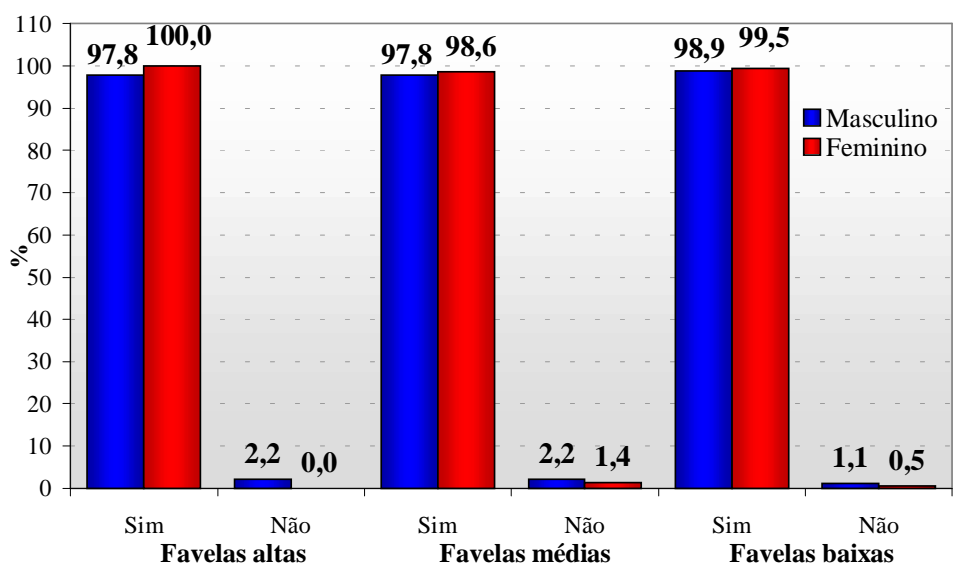

Os resultados são similares, quanto à importância do domínio de computação, para a pessoa entrevistada obter emprego.

Gráfico 3.3.12: Importância do domínio de computação na conquista do emprego, por sexo e classe de favela

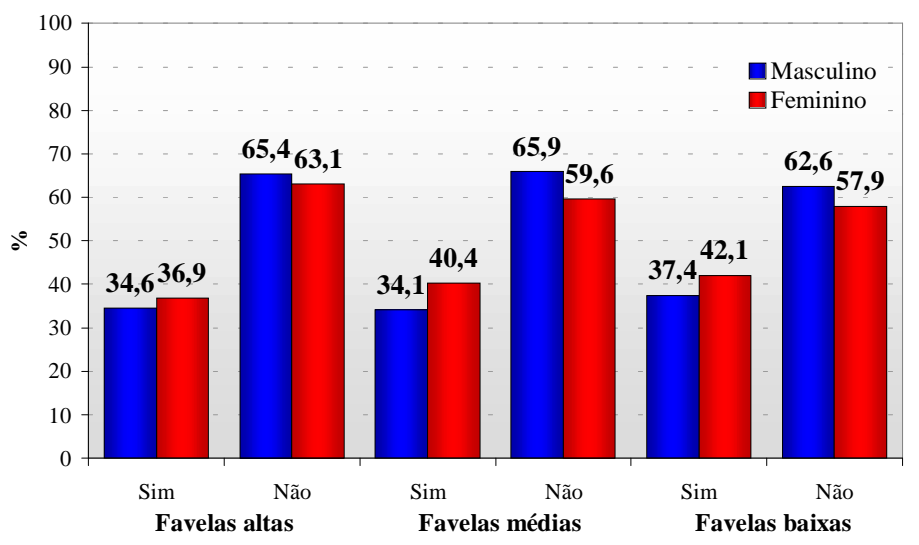

No momento de se conseguir um emprego, a exigência do domínio de computação era maior para os homens do que para as mulheres. Isto ocorria, possivelmente, porque uma porcentagem significativa de mulheres realiza trabalhos domésticos e/ou de limpeza. 
Tabela 3.3.11: De que maneira a computação ajudou você a conseguir emprego

\begin{tabular}{|c|c|c|c|c|c|c|}
\hline \multirow[b]{3}{*}{ Através de informações } & \multicolumn{2}{|c|}{ Favelas Altas } & \multicolumn{2}{|c|}{ Favelas Médias } & \multicolumn{2}{|c|}{ Favelas Baixas } \\
\hline & Masculino & Feminino & Masculino & Feminino & Masculino & Feminino \\
\hline & 10,9 & 24,1 & 13,8 & 15,9 & 12,4 & 12,3 \\
\hline Na hora da entrevista & 28,1 & 16,7 & 15,6 & 21,5 & 27,0 & 39,7 \\
\hline Exigência do trabalho & 60,9 & 55,6 & 67,9 & 60,7 & 55,1 & 46,6 \\
\hline Outros motivos & - & 3,7 & 2,8 & 1,9 & 5,6 & 1,4 \\
\hline
\end{tabular}

Dados os problemas de representação da amostra a um no tocante ao nível de detalhamento, trataremos os dados relativos a faixa etária e cor, considerando o conjunto das favelas.

\section{4 - Análise por faixa etária ${ }^{9}$}

Embora a amostra esteja prejudicada, devido ao pequeno número de usuários maiores de 45 anos, vemos que o número de usuários diários é bastante similar, e o aumento do percentual com a idade talvez se deva ao fato de que os usuários adultos com acesso no trabalho devem utilizar o computador constantemente. Já na faixa de uso uma vez por semana, possivelmente não ligada a trabalho, a tendência se inverte: são os mais jovens que apresentam maior frequiência de uso. Esse raciocínio se complementa na última faixa, dos que raramente utilizam o computador, na qual o grupo de mais de 45 anos apresenta a porcentagem mais alta.

Tabela 3.4.1: Freqüência de utilização do microcomputador, por faixa de idade

\begin{tabular}{|c|c|c|c|}
\hline & Até 24 anos & 25 a 44 anos & 45 anos ou mais \\
\hline Diariamente & 26,8 & 32,6 & 33,3 \\
\hline Pelo menos uma vez por semana & 30,3 & 25,3 & 13,8 \\
\hline Eventualmente & 14,7 & 12,0 & 10,3 \\
\hline Raramente & 28,1 & 30,1 & 42,5 \\
\hline
\end{tabular}

\footnotetext{
${ }^{9}$ Todas as tabelas desta seção mostram percentuais relativos ao próprio grupo.
} 
No que se refere ao caminho percorrido para usar computador, na medida em que passamos para as faixas de idade mais altas o principal diferencial é a importância do local de trabalho. No entanto, quando se trata do uso de cursos especializados, o caminho é inverso.

Tabela 3.4.2: Como aprendeu a utilizar o microcomputador, por faixa de idade

\begin{tabular}{|c|c|c|c|}
\hline & Até 24 anos & 25 a 44 anos & 45 anos ou mais \\
\hline Sozinho, por tentativas & 14,5 & 15,9 & 15,7 \\
\hline Sozinho, c/ ajuda de manuais & 1,2 & 2,3 & 3,4 \\
\hline Com orientação, no trabalho & 3,1 & 11,6 & 16,9 \\
\hline Com ajuda de amigos & 12,1 & 11,4 & 15,7 \\
\hline Em cursos especializados & 64,3 & 55,3 & 44,9 \\
\hline De outra meneira & 4,7 & 3,5 & 3,4 \\
\hline
\end{tabular}

Em geral, não há diferenças significativas quanto aos tipos de programas utilizados pelos grupos etários, a não ser quanto a jogos e Internet. Nestes casos, o uso é tão mais freqüente quanto menores as faixas etárias consideradas.

Tabela 3.4.3: Tipos de programas mais utilizados, por faixa de idade

\begin{tabular}{lcccc}
\hline & & & \\
\hline \hline & Até 24 anos & 25 a 44 anos & 45 anos ou mais \\
\cline { 2 - 3 } Processadores de texto & 77,6 & 78,3 & 75,0 \\
Planilhas eletrônicas & 45,5 & 54,1 & 43,2 \\
Programas de apres. gráfica & 32,1 & 31,6 & 18,2 \\
Linguagens de programação & 5,4 & & 4,8 & 6,8 \\
Jogos & 64,5 & 42,9 & 34,1 \\
Outros (específicos) & 4,0 & 7,0 & 5,7 \\
\hline
\end{tabular}

Tabela 3.4.4: Utilização da Internet, por faixa de idade

\begin{tabular}{|c|c|c|c|}
\hline & Até 24 anos & 25 a 44 anos & 45 anos ou mais \\
\hline Sim & 66,0 & 55,4 & 40,0 \\
\hline Não & 34,0 & 44,6 & 60,0 \\
\hline
\end{tabular}

Em relação ao motivo para não usar a Internet, a falta de local de acesso é indicada como o fator mais importante por todas as faixas, em particular entre os mais jovens. Quanto aos outros fatores, as diferenças percentuais não chegam a ter relevância, a não ser o preço, que é considerado importante por $14.8 \%$ dos maiores de 45 anos, e por 
6.4\% dos menores de 24 anos. Possivelmente, a explicação seja de ordem subjetiva, pois as pessoas mais idosas valorizam mais o dinheiro.

Tabela 3.4.5: Motivos para não acessar a Internet, por faixa de idade

\begin{tabular}{lcccc}
\hline \hline & Até 24 anos & & 25 a 44 anos & 45 anos ou mais \\
\cline { 2 - 3 } Não possui local onde possa acessar & 61,7 & 67,3 & 51,9 \\
Falta de interesse & 12,4 & & 9,0 & 16,7 \\
Acha muito complicado & 9,8 & & 8,3 & 7,4 \\
Acha caro & 6,4 & & 5,6 & 14,8 \\
Não tem tempo & 9,8 & 9,8 & 9,3 \\
\hline
\end{tabular}

Entre os usuários de Internet, a freqüência tende a ser maior, na medida em que aumenta a faixa de idade. A provável razão para isto é que, nessas faixas, a Internet está associada ao trabalho cotidiano.

Tabela 3.4.6: Frequiência de acesso à Internet

\begin{tabular}{lcccc}
\hline \hline & Até 24 anos & 25 a 44 anos & 45 anos ou mais \\
\cline { 2 - 3 } Mais de 1 vez ao dia & 11,5 & & 17,9 & 20,6 \\
Uma vez ao dia & 14,0 & & 14,0 & 14,7 \\
Uma vez por semana & 31,5 & & 26,4 & 20,6 \\
Mais de 1 vez por semana & 25,0 & 25,5 & 26,5 \\
Uma vez ao mês & 18,0 & 16,1 & 17,6 \\
\hline
\end{tabular}

Em termos de tipos de sites, vemos que aqueles associados a utilidade/funcionalidade são, com exceção das lojas virtuais, os mais utilizados pelas faixas superiores de idade, enquanto os sites de diversão/entretenimentos, o são pelas faixas mais jovens. A faixa de 25 a 44 anos apresenta altos índices de utilização, em praticamente todas as faixas. 
Tabela 3.4.7: Tipos de programas mais utilizados, por faixa de idade

\begin{tabular}{lcccc}
\hline \hline & Até 24 anos & 25 a 44 anos & 45 anos ou mais \\
\cline { 2 - 3 } Webmail & 36,7 & 36,9 & 42,9 \\
Lojas virtuais & 10,7 & & 15,2 & 8,6 \\
Sites de provador & 48,6 & 50,3 & 42,9 \\
Sites de busca / pesquisa & 69,6 & 67,1 & 65,7 \\
Site de revistas & 28,7 & 34,1 & 14,3 \\
Sites de jornais & 31,9 & 50,6 & 37,1 \\
Utilidade pública & 20,7 & 42,7 & 37,1 \\
Sites de empresas & 14,9 & 29,0 & 40,0 \\
Sites de música & 55,3 & 43,6 & 20,0 \\
Sites de esportes & 35,8 & 36,0 & 22,9 \\
Sites infantis & 7,3 & 9,8 & 8,6 \\
Outros tipos de sites (específicos) & 11,3 & 13,4 & 11,4 \\
\hline
\end{tabular}

Em relação à utilização da Internet para realizar cursos, as respostas são praticamente homogêneas, em todas as faixas de idade.

Tabela 3.4.8: Predisposição para a realização de cursos pela Internet, por faixa de idade

\begin{tabular}{lccc}
\hline \hline \multirow{3}{*}{$\operatorname{Sim}$} & Até 24 anos & $\frac{25 \text { a 44 anos }}{35,3}$ & $\frac{45 \text { anos ou mais }}{38,2}$ \\
\cline { 2 - 4 } Não & 63,0 & 64,4 & 61,8 \\
\hline
\end{tabular}

A utilização da Internet para fazer negócios, cujo detalhamento aparece na próxima tabela, aumenta com a faixa de idade. 
Tabela 3.4.9: Utilização da internet para fazer negócios?

\begin{tabular}{lccc}
\hline \hline & Até 24 anos & 25 a 44 anos & 45 anos ou mais \\
\cline { 2 - 4 } & 16,5 & 34,2 & 40,0 \\
Não & 83,5 & 65,8 & 60,0 \\
\hline
\end{tabular}

Enquanto a faixa de idade acima de 45 anos utiliza a Internet predominantemente para movimentação bancária e pagamento de contas, nas faixas de idade mais baixa predominam as compras, informação de preços e pagamentos de contas. Na faixa intermédia, a distribuição é mais equilibrada, embora a utilização para compras apresente a maior incidência.

Tabela 3.4.10: Tipo de negócio realizado na Internet, por faixa de idade

\begin{tabular}{|c|c|c|c|}
\hline & Até 24 anos & 25 a 44 anos & 45 anos ou mais \\
\hline Compra & 35,2 & 46,0 & 28,6 \\
\hline Venda & 14,8 & 10,6 & 7,1 \\
\hline Informação de preços & 26,1 & 27,4 & 21,4 \\
\hline Pagamento de contas & 27,3 & 28,3 & 42,9 \\
\hline Movimentação bancária & 18,2 & 31,9 & 42,9 \\
\hline Outros & 13,6 & 8,0 & 14,3 \\
\hline
\end{tabular}

$\mathrm{O}$ acesso a sites de textos em outras línguas apresenta percentuais similares entre as faixas de idade mais alta e mais baixa, enquanto cai abruptamente na faixa de 25 a 44 anos. A explicação para esta tendência é que o universo de maiores de 45 anos que utiliza a Internet é pequeno e, possivelmente, bastante qualificado, enquanto os jovens de hoje acessam mais cursos de línguas estrangeiras, em particular inglês.

Tabela 3.4.11: Acesso a sites de textos em outras línguas

\begin{tabular}{lccc}
\hline \hline \multirow{3}{*}{$\operatorname{sim}$} & Até 24 anos & $\frac{25 \text { a 44 anos }}{12,8}$ & 45 anos ou mais \\
\cline { 2 - 4 } Não & 20,3 & & 22,9 \\
\hline
\end{tabular}


A afirmação anterior se confirma pela tabela a seguir, que indica a importância de cursos de línguas (privados) que hoje estão disponíveis em todas as favelas, a preços competitivos (enquanto anteriormente eram poucos e caros).

Tabela 3.4.12: Local de aprendizado de línguas por faixas de idade

\begin{tabular}{lccc}
\hline & & & \\
\hline \hline & Até 24 anos & 25 a 44 anos & 45 anos ou mais \\
\cline { 2 - 3 } \cline { 4 - 4 } Curso & 42,4 & 48,7 & 25,0 \\
Escola & 38,0 & 23,1 & 37,5 \\
Sozinho & 9,8 & 15,4 & 12,5 \\
Na própria Internet & 4,3 & 7,7 & 0,0 \\
De outra maneira & 5,4 & 5,1 & 25,0 \\
\hline
\end{tabular}

O uso da Internet como instrumento de contato com pessoas de outros países é alto em todas as faixas, particularmente entre os mais jovens.

Tabela 3.4.13: Interesse em contatar pessoas de outros países, pela Internet

\begin{tabular}{|c|c|c|c|}
\hline & Até 24 anos & 25 a 44 anos & 45 anos ou mais \\
\hline Sim & 81,3 & $\overline{66,6}$ & 77,1 \\
\hline Não & 18,7 & 33,4 & 22,9 \\
\hline
\end{tabular}

Nesses contatos, os tipos de assuntos são os mais diversos, sem predomínio claro de um tema.

Tabela 3.4.14: Temas mais citados, por faixa de idade

\begin{tabular}{|c|c|c|c|}
\hline & Até 24 anos & 25 a 44 anos & 45 anos ou mais \\
\hline Como vivem, como é lá & 18,0 & 13,4 & 12,5 \\
\hline Cultura, atualidade, informação & 23,6 & 29,7 & 20,8 \\
\hline Bate-papo & 2,0 & 2,9 & 0,0 \\
\hline Assuntos gerais & 22,8 & 16,7 & 16,7 \\
\hline Música, jogos, esporte, lazer & 10,4 & 3,3 & 0,0 \\
\hline Pesquisa, educação, línguas & 2,2 & 5,3 & 4,2 \\
\hline Religião & 1,4 & 5,3 & 4,2 \\
\hline Política, economia, emprego & 10,7 & 13,9 & 4,2 \\
\hline Turismo, segurança & 2,5 & 3,8 & 8,3 \\
\hline Sociedade, saúde, pobreza & 8,7 & 12,0 & 4,2 \\
\hline Informática, tecnologia & 1,4 & 2,9 & 4,2 \\
\hline Outras & 2,2 & 2,4 & 20,8 \\
\hline
\end{tabular}


Entre os usuários de Internet, o número de pessoas com e-mail aumenta com a faixa de idade o que, novamente, pode ser relacionado ao uso no trabalho.

Tabela 3.4.15: Utilização de e-mail, por faixa de idade

\begin{tabular}{|c|c|c|c|}
\hline & Até 24 anos & 25 a 44 anos & 45 anos ou mais \\
\hline Sim & 42,7 & 56,1 & 68,6 \\
\hline Não & 57,3 & 43,9 & 31,4 \\
\hline
\end{tabular}

Não há diferenças de intensidade no uso de e-mail, entre as várias faixas etárias, embora a faixa até 24 anos apresente uma intensidade menor, possivelmente porque para as pessoas desta faixa o uso do e-mail tem um custo associado, enquanto para muitas pessoas das faixas mais altas existe a possibilidade de acesso no trabalho.

Tabela 3.4.16: Frequiência de utilização de e-mail, por faixa de idade

\begin{tabular}{|c|c|c|c|}
\hline & Até 24 anos & 25 a 44 anos & 45 anos ou mais \\
\hline Mais de 1 vez ao dia & 19,6 & 24,6 & 25,0 \\
\hline Uma vez ao dia & 12,5 & 19,3 & 12,5 \\
\hline Uma vez por semana & 30,8 & 19,8 & 20,8 \\
\hline Mais de 1 vez por semana & 23,2 & 20,3 & 20,8 \\
\hline Uma vez ao mês & 10,7 & 8,6 & 12,5 \\
\hline Nunca & 3,1 & 7,5 & 8,3 \\
\hline
\end{tabular}

Os contatos com novas pessoas através da Internet aumentam, na medida em que a idade diminui. Naturalmente, jovens estão mais abertos e disponíveis para novas relações.

Tabela 3.4.17: Conhecimento de pessoas pela Internet

\begin{tabular}{|c|c|c|c|}
\hline & Até 24 anos & 25 a 44 anos & 45 anos ou mais \\
\hline Sim & 64,1 & 41,0 & 25,0 \\
\hline Não & 35,9 & 59,0 & 75,0 \\
\hline
\end{tabular}


As pessoas conhecidas através da Internet são, em todas as faixas etárias, de nível socioeconômico superior ou igual ao do entrevistado.

Tabela 3.4.18: Nível socioeconômico das pessoas conhecidas pela Internet, por faixa de idade

\begin{tabular}{|c|c|c|c|}
\hline & Até 24 anos & 25 a 44 anos & 45 anos ou mais \\
\hline Nível socioeconômico mais alto & 42,7 & 50,8 & 50,0 \\
\hline Mesmo nível socioeconômico & 54,7 & 45,9 & 50,0 \\
\hline Nível socioeconômico mais baixo & 2,6 & 3,3 & - \\
\hline
\end{tabular}

Os contatos feitos por jovens e adultos até 44 anos têm como foco principal o intercâmbio de informações, enquanto para os de mais de 45 anos visam a indicações para trabalho. Na faixa de 45 anos ou mais, a grande maioria dos contatos tem um objetivo específico enquanto nas outras faixas é alto o percentual de contatos sem um interesse determinado.

Tabela 3.4.19: De que maneira as pessoas que você conheceu pela Internet o ajudaram?

\begin{tabular}{|c|c|c|c|}
\hline & Até 24 anos & 25 a 44 anos & 45 anos ou mais \\
\hline Indicação para trabalho & 9,4 & 4,2 & 50,0 \\
\hline Não obtenção de inf. s/ temas de meu interesse & 31,2 & 43,7 & 33,3 \\
\hline Ajuda em outros assuntos ou temas & 6,5 & 9,9 & - \\
\hline Nenhum tipo de ajuda & 52,9 & 42,3 & 16,7 \\
\hline
\end{tabular}

O percentual de participação em grupos de chat é alto entre os jovens, decrescendo na medida em que aumenta a faixa de idade.

Tabela 3.4.20: Participação em chats, por faixa de idade

\begin{tabular}{|c|c|c|c|}
\hline & Até 24 anos & 25 a 44 anos & 45 anos ou mais \\
\hline Sim & $\overline{51,4}$ & 26,6 & 16,7 \\
\hline Não & 48,6 & 73,4 & 83,3 \\
\hline
\end{tabular}

A importância do e-mail como instrumento de trabalho aumenta com a idade, como demonstram os dados a seguir. 
Tabela 3.4.21: Finalidade da utilização de e-mail, por faixa de idade

\begin{tabular}{lcccc}
\hline \hline & Até 24 anos & 25 a 44 anos & 45 anos ou mais \\
\cline { 2 - 3 } Somente para trabalho & 5,9 & & 15,6 & 29,2 \\
Mais $\mathrm{p} /$ trabalho que $\mathrm{p} /$ lazer & 7,3 & & 20,1 & 16,7 \\
Metade $\mathrm{p} /$ trabalho metade $\mathrm{p} /$ lazer & 18,6 & & 34,1 & 29,2 \\
Mais $\mathrm{p} /$ lazer do que p/ trabalho & 16,8 & & 15,1 & 4,2 \\
Somente para lazer & 41,4 & 15,1 & 20,8 \\
\hline
\end{tabular}

É praticamente consensual em todas as faixas de idade o reconhecimento da importância da informática para a conquista de emprego.

Tabela 3.4.22: Opinião sobre a importância do domínio de informática para a conquista de emprego, entre os usuários de microcomputador, por faixa de idade

\begin{tabular}{|c|c|c|c|}
\hline & Até 24 anos & 25 a 44 anos & 45 anos ou mais \\
\hline Sim & 98,7 & 98,3 & 98,9 \\
\hline Não & 1,3 & 1,7 & 1,1 \\
\hline
\end{tabular}

O fator mais importante da influência do uso do computador na obtenção do emprego, foi como exigência do trabalho:

Tabela 3.4.23: Como a computação ajudou na obtenção do emprego, por faixa de idade

\begin{tabular}{lcccc}
\hline \hline & Até 24 anos & 25 a 44 anos & 45 anos ou mais \\
\cline { 2 - 2 } Através de informação & 14,5 & 13,3 & 26,1 \\
Na hora da entrevista & 27,0 & & 22,7 & 8,7 \\
Exigência do trabalho & 58,1 & 60,1 & 52,2 \\
Outros motivos & 0,4 & 3,9 & 13,0 \\
\hline
\end{tabular}




\section{5 - Análise por cor ${ }^{10}$}

A utilização do computador é muito mais intensa entre os brancos. Existe um diferencial entre pardos e negros, a favor dos pardos, porém bem menor do que a diferença em relação aos brancos.

Tabela 3.5.1:Freqüência de utilização do microcomputador, por cor/raça

\begin{tabular}{|c|c|c|c|}
\hline & Branco & Negro & Pardo \\
\hline Diariamente & 33,8 & 23,0 & 27,3 \\
\hline Pelo menos uma vez por semana & 25,3 & 28,7 & 29,2 \\
\hline Eventualmente & 16,3 & 11,1 & 11,1 \\
\hline Raramente & 24,7 & 37,3 & 32,5 \\
\hline
\end{tabular}

Não há diferenças significativas entre os grupos de cor, com relação à aprendizagem, sendo majoritário o grupo que aprendeu em cursos especializados.

Tabela 3.5.2: Maneira como aprendeu usar o computador, por cor/raça

\begin{tabular}{lccccc}
\hline \hline & Branco & & Negro & & Pardo \\
\cline { 2 - 2 } \cline { 5 - 6 } \cline { 5 - 6 } Sozinho, por tentativas & 14,8 & & 16,6 & & 15,3 \\
Sozinho, com ajuda dos manuais & 2,0 & & 1,2 & & 1,8 \\
Com orientação, no meu local de trabalho & 7,9 & & 4,0 & & 7,6 \\
Com ajuda de amigos & 12,0 & & 11,3 & & 12,8 \\
Em cursos especializados & 60,7 & & 62,8 & & 56,4 \\
De outra maneira & 2,6 & & 4,0 & & 6,1 \\
\hline
\end{tabular}

Não foram observadas diferenças relevantes entre os tipos de programas utilizados, fora a Internet, no uso desta, os negros apresentam um percentual menor.

Tabela 3.5.3: Tipos de programas mais utilizados por cor/raça

\begin{tabular}{|c|c|c|c|}
\hline & Branco & Negro & Pardo \\
\hline Processadores de texto & 76,8 & 77,6 & 78,3 \\
\hline Planilhas eletrônicas & 48,8 & 48,2 & 48,2 \\
\hline Programas de apres. gráfica & 32,2 & 27,3 & 30,8 \\
\hline Linguagens de programação & 6,1 & 2,9 & 5,4 \\
\hline Jogos & 52,9 & 51,4 & 56,2 \\
\hline Outros (específicos) & 6,7 & 4,1 & 3,7 \\
\hline
\end{tabular}

\footnotetext{
${ }^{10}$ Todas as tabelas desta seção mostram percentuais relativos ao próprio grupo.
} 
A tabela anterior é confirmada pela seguinte, na qual se observa que entre os negros o uso da Internet é menos freqüente do que entre pardos e brancos. Vale ressaltar que o diferencial de percentuais entre os gráficos possivelmente se deve ao fato de que os entrevistados nem sempre identificam a Internet como um programa específico.

Tabela 3.5.4: Utilização da Internet, por cor/raça

\begin{tabular}{|c|c|c|c|}
\hline & Branco & Negro & Pardo \\
\hline Sim & 62,4 & 52,0 & 60,9 \\
\hline Não & 37,6 & 48,0 & 39,1 \\
\hline
\end{tabular}

Entre os que não utilizam a Internet (mas são usuários de computador) as explicações apresentadas para isso são similares, entre os diferentes grupos de cor. A principal razão apontada é a falta de local de acesso.

Tabela 3.5.5: Motivos para não acessar a Internet, por cor/raça

\begin{tabular}{|c|c|c|c|}
\hline & Branco & Negro & Pardo \\
\hline Falta de local onde possa acessar & 66,9 & 66,1 & 58,3 \\
\hline Não tem interesse & 10,9 & 6,1 & 14,7 \\
\hline Acha muito complicado & 8,8 & 13,0 & 6,2 \\
\hline Acha caro & 4,2 & 5,2 & 10,4 \\
\hline Não tem tempo & 9,2 & 9,6 & 10,4 \\
\hline
\end{tabular}

A intensidade de uso é bastante similar entre brancos e pardos, e relativamente inferior entre os negros, como vemos abaixo:

Tabela 3.5.6: Freqüência de acesso à Internet, por cor/raça

\begin{tabular}{|c|c|c|c|}
\hline & "Branco & Neqro & Pardo \\
\hline Mais de 1 vez ao dia & 14,8 & 11,5 & 14,4 \\
\hline Uma vez ao dia & 14,5 & 10,7 & 15,3 \\
\hline Mais de 1 vez por semana & 27,1 & 23,8 & 23,9 \\
\hline Uma vez por semana & 28,1 & 30,3 & 29,4 \\
\hline Uma vez ao mês & 15,5 & 23,8 & 17,1 \\
\hline
\end{tabular}

Em relação aos tipos de site acessados, não existem diferenças relevantes entre os diferentes grupos de cor. 
Tabela 3.5.7: Tipos de sites mais acessados, por cor/raça

\begin{tabular}{lccccc}
\hline \hline & Branco & & Negro & & Pardo \\
\cline { 2 - 2 } \cline { 5 - 5 } Webmail & 39,8 & & 34,4 & & 33,7 \\
Lojas virtuais & 11,0 & & 9,0 & & 14,3 \\
Sites de provador & 56,9 & & 46,7 & & 37,7 \\
Sites de busca / pesquisa & 73,7 & & 66,4 & & 62,3 \\
Site de revistas & 31,3 & & 27,0 & & 28,6 \\
Sites de jornais & 41,9 & & 32,8 & & 38,0 \\
Utilidade pública & 28,6 & & 33,6 & & 29,2 \\
Sites de empresas & 24,1 & & 18,9 & & 18,5 \\
Sites de música & 51,1 & & 52,5 & & 46,5 \\
Sites de esportes & 36,8 & & 34,4 & & 34,7 \\
Sites infantis & 8,0 & & 6,6 & & 9,4 \\
Outros tipos de sites (específicos) & 13,5 & & 11,5 & & 10,0 \\
\hline
\end{tabular}

A mesma tendência se observa em relação ao uso da Internet para realizar cursos, como podemos verificar na tabela abaixo:

Tabela 3.5.8: Predisposição para a realização de cursos pela Internet, entre os usuários de microcomputador, por cor/raça

\begin{tabular}{|c|c|c|c|}
\hline & Branco & Negro & Pardo \\
\hline Sim & 34,6 & 38,2 & 37,6 \\
\hline Não & 65,4 & 61,8 & 62,4 \\
\hline
\end{tabular}

O uso da Internet para realizar negócios apresenta diferenças significativas entre os diferentes grupos, sendo de $29.9 \%$ entre brancos, $21.5 \%$ entre pardos e $13.7 \%$ entre negros.

Tabela 3.5.9: Utilização da Internet para fazer negócios, entre os usuários de microcomputador, por cor/raça

\begin{tabular}{|c|c|c|c|}
\hline & Branco & Negro & Pardo \\
\hline Sim & 29,9 & 13,7 & 21,5 \\
\hline Não & 70,1 & 86,3 & 78,5 \\
\hline
\end{tabular}

O tipo de negócio realizado segue linhas similares entre os grupos. 
Tabela 3.5.10: Tipo de negócio realizado na Internet, por cor/raça

\begin{tabular}{lccccc}
\hline \hline & & & & \\
\cline { 2 - 2 } \cline { 5 - 5 } \cline { 5 - 5 } Compra & 39,7 & & 50,0 & & \\
\cline { 5 - 6 } Venda & 10,7 & & 5,6 & & 17,4 \\
Informação de preços & 28,1 & & 27,8 & & 24,6 \\
Pagamento de contas & 31,4 & & 50,0 & & 18,8 \\
Movimentação bancária & 33,9 & & 22,2 & & 14,5 \\
Outros & 9,9 & & 5,6 & & 14,5 \\
\hline
\end{tabular}

O uso de sites em outras línguas é mais freqüente entre brancos, seguido por pardos e negros o que, possivelmente, indica um diferencial de níveis escolar e de renda (que envolve condições para pagar cursos privados):

Tabela 3.5.11: Acesso a sites de textos em outras línguas, entre usuários de microcomputador, por cor/raça

\begin{tabular}{|c|c|c|c|}
\hline & Branco & Negro & Pardo \\
\hline Sim & 19,4 & 12,9 & 17,0 \\
\hline Não & 80,6 & 87,1 & 83,0 \\
\hline
\end{tabular}

Como mostra a tabela a seguir, a hipótese anterior se confirma, no tocante à aprendizagem de línguas: enquanto os brancos as aprendem principalmente em cursos especializados, os pardos e negros dependem da escola regular.

Tabela 3.5.12: Local onde aprendeu línguas, por cor/raça

\begin{tabular}{|c|c|c|c|}
\hline & Branco & Negro & Pardo \\
\hline Curso & 52,2 & 35,7 & 34,0 \\
\hline Escola & 24,6 & 57,1 & 38,0 \\
\hline Sozinho & 8,7 & 7,1 & 16,0 \\
\hline Na própria Internet & 7,2 & - & 4,0 \\
\hline De outra maneira & 7,2 & - & 8,0 \\
\hline
\end{tabular}

O interesse em ter contato com comunidades de outros países é similar entre os diferentes grupos. 
Tabela 3.5.13: Interesse em contatar pessoas de outros países, entre moradores que utilizam microcomputador, por cor/raça

\begin{tabular}{|c|c|c|c|}
\hline & Branco & Negro & Pardo \\
\hline Sim & 72,3 & 83,9 & 76,9 \\
\hline Não & 27,7 & 16,1 & 23,1 \\
\hline
\end{tabular}

O mesmo vale para os temas preferidos, nos contatos via Internet, como mostra a tabela a seguir:

Tabela 3.5.14: Tipos de assuntos mais citados, por cor/raça

\begin{tabular}{|c|c|c|c|}
\hline & Branco & Negro & Pardo \\
\hline Como vivem, como é lá & 14,8 & 19,1 & 16,3 \\
\hline Cultura, atualidade, informação & 24,0 & 24,7 & 26,4 \\
\hline Bate-papo & 2,8 & 0,0 & 1,8 \\
\hline Assuntos gerais & 21,2 & 19,1 & 21,6 \\
\hline Música, jogos, esporte, lazer & 8,0 & 10,1 & 6,2 \\
\hline Pesquisa, educação, línguas & 3,2 & 4,5 & 3,1 \\
\hline Religião & 3,6 & 4,5 & 1,3 \\
\hline Política, economia, emprego & 12,4 & 4,5 & 13,2 \\
\hline Turismo, segurança & 3,2 & 2,2 & 3,5 \\
\hline Sociedade, saúde, pobreza & 10,4 & 7,9 & 10,6 \\
\hline Informática, tecnologia & 0,8 & 5,6 & 1,8 \\
\hline Outros & 4,0 & 4,5 & 1,8 \\
\hline
\end{tabular}

Em relação ao uso de e-mail entre aqueles que têm acesso à Internet, todos os grupos apresentam porcentagens similares, em torno da metade.

Tabela 3.5.15: Utilização de e-mail por cor/raça

\begin{tabular}{|c|c|c|c|}
\hline & Branco & Negro & Pardo \\
\hline Sim & 49,4 & 48,0 & 49,2 \\
\hline Não & 50,6 & 52,0 & 50,8 \\
\hline
\end{tabular}

Os brancos apresentam a maior intensidade do uso de e-mail. Surpreendentemente, os negros apresentam uma intensidade mais alta que os pardos. Uma hipótese possível é que, sendo o lugar de trabalho o principal local de acesso dos negros, exista um incentivo ao uso de e-mail. 
Tabela 3.5.16: Frequiência com que verifica o e-mail, por cor/raça

\begin{tabular}{|c|c|c|c|}
\hline & Branco & Negro & Pardo \\
\hline Mais de 1 vez ao dia & 26,5 & 24,6 & 15,9 \\
\hline Uma vez ao dia & 15,8 & 13,1 & 15,9 \\
\hline Uma vez por semana & 24,0 & 23,0 & 27,4 \\
\hline Mais de 1 vez por semana & 24,0 & 16,4 & 21,3 \\
\hline Uma vez ao mês & 6,6 & 13,1 & 12,8 \\
\hline Nunca & 3,1 & 9,8 & 6,7 \\
\hline
\end{tabular}

Quanto à importância da Internet para conhecer pessoas, os resultados dos diferentes grupos de cor são similares.

Tabela 3.5.17: Conhecimento de pessoas pela Internet, por cor/raça

\begin{tabular}{|c|c|c|c|}
\hline & Branco & Negro & Pardo \\
\hline Sim & 53,1 & 50,8 & 51,8 \\
\hline Não & 46,9 & 49,2 & 48,2 \\
\hline
\end{tabular}

Como era de se esperar, os negros - geralmente pessoas que têm renda mais baixa conhecem um maior número de pessoas com renda mais alta. O percentual diminui entre os pardos, e mais ainda entre os brancos. Novamente se repete a tendência de baixa porcentagem de contato com pessoas de nível socioeconômico inferior.

Tabela 3.5.18: Nível socioeconômico das pessoas conhecidas pela Internet, por cor/raça

\begin{tabular}{|c|c|c|c|}
\hline & Branco & Negro & Pardo \\
\hline Nível socioeconômico mais alto & 41,5 & 59,1 & 46,1 \\
\hline Mesmo nível socioeconômico & 57,3 & 40,9 & 48,7 \\
\hline Nível socioeconômico mais baixo & 1,2 & 0,0 & 5,3 \\
\hline
\end{tabular}

Não existem diferenças significativas em relação ao tipo de ajuda prestada por pessoas conhecidas na Internet, como mostra a tabela abaixo: 
Tabela 3.5.19: De que maneira as pessoas conhecidas através da Internet ajudaram você, por cor/raça

\begin{tabular}{|c|c|c|c|}
\hline & Branco & Negro & Pardo \\
\hline Indicação para trabalho & 6,1 & 6,9 & 8,6 \\
\hline Não obtenção de inf. s/ temas de meu interesse & 42,4 & 31,0 & 29,6 \\
\hline Essas pessoas me ajudaram em outras coisas & 6,1 & 10,3 & 8,6 \\
\hline Essas pessoas não me ajudaram em nada & 45,5 & 51,7 & 53,1 \\
\hline
\end{tabular}

Embora não exista diferença técnica relevante quanto à participação em grupos de chat, surpreende a porcentagem mais alta entre os negros.

Tabela 3.5.20: Participação em chats, por cor/raça

\begin{tabular}{lccccc}
\hline \hline & Branco & & Negro & & Pardo \\
\cline { 2 - 2 } \cline { 5 - 5 } Sim & 39,3 & & 43,3 & & 36,0 \\
Não & 60,7 & & 56,7 & & 64,0 \\
\hline
\end{tabular}

A importância do e-mail para o trabalho, entre os negros, confirma de certa forma a hipótese anterior sobre o local de trabalho como principal fonte de acesso à Internet, neste grupo.

Tabela 3.5.21: Objetivo da utilização do e-mail, por cor/raça

\begin{tabular}{|c|c|c|c|}
\hline & Branco & Negro & Pardo \\
\hline Somente para trabalho & 8,9 & 12,1 & 13,7 \\
\hline Mais para trabalho do que $\mathrm{p} /$ lazer & 14,1 & 17,2 & 11,2 \\
\hline Metade para o trabalho metade $\mathrm{p} /$ lazer & 37,2 & 25,9 & 26,7 \\
\hline Mais para o lazer do que $\mathrm{p} /$ trabalho & 14,1 & 17,2 & 13,7 \\
\hline Somente para lazer & 25,7 & 27,6 & 34,8 \\
\hline
\end{tabular}

Novamente aparece como consensual a importância de saber computação para obter emprego. 
Tabela 3.5.22 Opinião sobre a importância do domínio de computação na conquista de emprego, entre moradores que utilizam microcomputador, por cor/raça

\begin{tabular}{|c|c|c|c|}
\hline & Branco & Negro & Pardo \\
\hline Sim & 98,9 & 98,8 & $\begin{array}{l}98,0 \\
\end{array}$ \\
\hline Não & 1,1 & 1,2 & 2,0 \\
\hline
\end{tabular}

A percepção da importância de saber computação apresenta certas diferenças, entre os diversos grupos de cor.

Tabela 3.5.23: Maneira como o domínio de computação ajudou na obtenção do emprego por cor/raça

\begin{tabular}{lccccc}
\hline \hline & Branco & & Negro & & Pardo \\
\cline { 2 - 2 } \cline { 5 - 5 } \cline { 5 - 5 } Através de informações & 13,6 & & 10,8 & & 17,2 \\
Na hora da entrevista & 17,3 & & 24,3 & & 31,2 \\
Exigência do trabalho & 66,4 & & 62,2 & & 48,9 \\
Outros motivos & 2,7 & & 2,7 & & 2,7 \\
\hline
\end{tabular}

\section{6 - Análise por faixa de renda ${ }^{11}$}

Como era de se esperar, na medida em que a renda aumenta, é maior a intensidade de uso do computador.

Tabela3.6.1: Freqüiência de utilização do computador, por faixa de renda

\begin{tabular}{|c|c|c|c|c|c|c|c|c|}
\hline & \multicolumn{2}{|c|}{ Até 240 reais } & \multicolumn{2}{|c|}{ De 241 a 720 reais } & \multicolumn{2}{|c|}{ De 721 a 1200 reais } & \multicolumn{2}{|c|}{ Mais de 1200 reais } \\
\hline & Renda & Renda & Renda & Renda & Renda & Renda & Renda & Renda \\
\hline & Familiar & Pessoal & Familiar & Pessoal & Familiar & Pessoal & Familiar & Pessoal \\
\hline Diariamente & 18,0 & 18,8 & 20,8 & 34,2 & 32,1 & 40,0 & 42,9 & 52,6 \\
\hline Pelo menos 1 vez por semana & 27,9 & 33,6 & 28,5 & 18,8 & 26,3 & 23,3 & 24,1 & 18,4 \\
\hline Eventualmente & 13,1 & 14,8 & 15,3 & 14,5 & 13,9 & 16,7 & 15,0 & 10,5 \\
\hline Raramente & 41,0 & 32,7 & 35,4 & 32,5 & 27,7 & 20,0 & 18,0 & 18,4 \\
\hline
\end{tabular}

$\mathrm{Na}$ medida em que a renda aumenta, é mais freqüente a aprendizagem por tentativas, enquanto que a utilização de cursos se torna mais freqüente com a diminuição de renda.

\footnotetext{
${ }^{11}$ Todas as tabelas desta seção mostram percentuais reativos ao próprio grupo.
} 
Isto porque quanto mais alto o nível de renda, maiores são as chances de se ter computador em casa, e aprender praticando.

Tabela 3.6.2: Maneira como aprendeu usar o microcomputador, por faixa de renda

\begin{tabular}{|c|c|c|c|c|c|c|c|c|}
\hline & \multicolumn{2}{|c|}{ Até 240 reais } & \multicolumn{2}{|c|}{ "De 241 a 720 reais } & \multicolumn{2}{|c|}{ De 721 a 1200 reais } & \multicolumn{2}{|c|}{ Mais de 1200 reais } \\
\hline & Renda & Renda & Renda & Renda & Renda & Renda & Renda & Renda \\
\hline & Familiar & Pessoal & Familiar & Pessoal & Familiar & Pessoal & Familiar & Pessoal \\
\hline Sozinho, por tentativas & 8,2 & 12,9 & 14,5 & 16,1 & 12,3 & 7,9 & 12,9 & 15,4 \\
\hline Sozinho, com ajuda de manuais & 0,0 & 1,2 & 0,7 & 1,7 & 2,2 & 0,0 & 0,8 & 2,6 \\
\hline Com orientação, no meu local de trabalho & 9,8 & 3,3 & 5,5 & 16,9 & 13,0 & 20,6 & 12,9 & 10,3 \\
\hline Com ajuda de amigos & 8,2 & 12,4 & 9,7 & 5,9 & 9,4 & 7,9 & 7,6 & 5,1 \\
\hline Em cursos especializados & 68,9 & 63,1 & 61,4 & 55,1 & 60,1 & 58,7 & 59,1 & 59,0 \\
\hline De outra maneira & 4,9 & 7,0 & 8,3 & 4,2 & 2,9 & 4,8 & 6,8 & 7,7 \\
\hline
\end{tabular}

$\mathrm{Na}$ medida em que passamos para as camadas mais altas de renda a tendência é de uma maior diversificação de tipos de programas utilizados.

Tabela 3.6.3: Tipos de programas mais utilizados, por faixa de renda

\begin{tabular}{|c|c|c|c|c|c|c|c|c|}
\hline & \multicolumn{2}{|c|}{ Até 240 reais } & \multicolumn{2}{|c|}{ De 241 a 720 reais } & \multicolumn{2}{|c|}{ De 721 a 1200 reais } & \multicolumn{2}{|c|}{ Mais de 1200 reais } \\
\hline & Renda & Renda & Renda & Renda & Renda & Renda & Renda & Renda \\
\hline & Familiar & Pessoal & Familiar & Pessoal & Familiar & Pessoal & Familiar & Pessoa \\
\hline Processadores de texto & 83,6 & 80,0 & 78,2 & 81,7 & 81,9 & 83,3 & 79,1 & 79,5 \\
\hline Planilhas eletrônicas & 52,5 & 47,7 & 57,0 & 64,2 & 55,8 & 61,7 & 62,0 & 61,5 \\
\hline Programas de apresentação gráfica & 31,1 & 32,1 & 34,5 & 30,8 & 37,7 & 45,0 & 35,7 & 33,3 \\
\hline Linguagens de programação & 3,3 & 3,3 & 2,8 & 7,5 & 8,0 & 10,0 & 9,3 & 17,9 \\
\hline Jogos & 62,3 & 66,0 & 62,0 & 58,3 & 54,3 & 53,3 & 59,7 & 46,2 \\
\hline Outros & 3,3 & 3,8 & 3,5 & 5,8 & 5,8 & 8,3 & 7,0 & 10,3 \\
\hline
\end{tabular}

Somente nas camadas mais altas de renda encontramos diferenciais mais significativos em relação ao de uso da Internet.

Tabela 3.6.4: Utilização da Internet, por faixa de renda

\begin{tabular}{|c|c|c|c|c|c|c|c|c|}
\hline & \multicolumn{2}{|c|}{ Até 240 reais } & \multicolumn{2}{|c|}{ De 241 a 720 reais } & \multicolumn{2}{|c|}{ De 721 a 1200 reais } & \multicolumn{2}{|c|}{ Mais de 1200 reais } \\
\hline & Renda & Renda & Renda & Renda & Renda & Renda & Renda & Renda \\
\hline & Familiar & Pessoal & Familiar & Pessoal & Familiar & Pessoal & Familiar & Pessoal \\
\hline Sim & 57,4 & 59,3 & 57,4 & 59,3 & 58,6 & 60,9 & 69,4 & 60,5 \\
\hline Não & 42,6 & 40,7 & 42,6 & 40,7 & 41,4 & 39,1 & 30,6 & 39,5 \\
\hline
\end{tabular}


Tabela 3.6.5: Motivos para não acessar a Internet, por faixa de renda

\begin{tabular}{|c|c|c|c|c|c|c|c|c|}
\hline & \multicolumn{2}{|c|}{ Até 240 reais } & \multicolumn{2}{|c|}{ De 241 a 720 reais } & \multicolumn{2}{|c|}{ De 721 a 1200 reais } & \multicolumn{2}{|c|}{ Mais de 1200 reais } \\
\hline & Renda & Renda & Renda & Renda & Renda & Renda & Renda & Renda \\
\hline & Familiar & Pessoal & Familiar & Pessoal & Familiar & Pessoal & Familiar & Pessoal \\
\hline Não possui local onde acessar & 76,0 & 62,7 & 66,1 & 54,3 & 59,6 & 48,0 & 51,2 & 46,7 \\
\hline Não possui interesse & 8,0 & 12,4 & 7,1 & 10,9 & 17,5 & 20,0 & 12,2 & 20,0 \\
\hline Acha muito complicado & 4,0 & 8,9 & 12,5 & 2,2 & 0,0 & 0,0 & 7,3 & 6,7 \\
\hline Caro & 8,0 & 7,7 & 3,6 & 13,0 & 10,5 & 16,0 & 14,6 & 20,0 \\
\hline Não tem tempo & 4,0 & 8,3 & 10,7 & 19,6 & 12,3 & 16,0 & 14,6 & 6,7 \\
\hline
\end{tabular}

$\mathrm{Na}$ medida que aumenta a renda, também aumenta a intensidade de uso da Internet:

Tabela 3.6.6: Freqüência de acesso à Internet, por faixa de renda

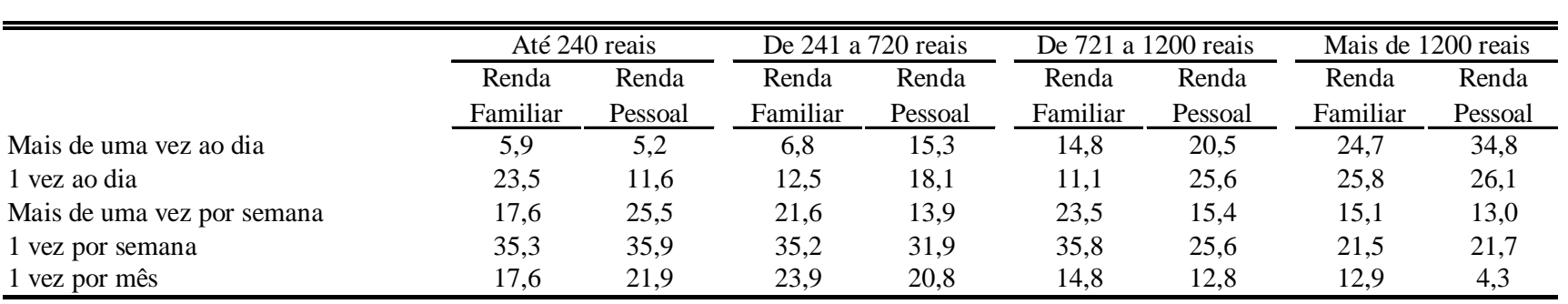

Não existem diferenças significativas, entre os tipos de sites acessados:

Tabela 3.6.7: Tipos de sites mais acessados, por faixa de renda

\begin{tabular}{|c|c|c|c|c|c|c|c|c|}
\hline & \multicolumn{2}{|c|}{ Até 240 reais } & \multicolumn{2}{|c|}{ De 241 a 720 reais } & \multicolumn{2}{|c|}{ "De 721 a 1200 reais } & \multicolumn{2}{|c|}{ Mais de 1200 reais } \\
\hline & Renda & Renda & Renda & Renda & Renda & Renda & Renda & Renda \\
\hline & Familiar & Pessoal & Familiar & Pessoal & Familiar & Pessoal & Familiar & Pessoal \\
\hline Webmail & 50,0 & 39,3 & 41,6 & 52,8 & 46,9 & 56,4 & 42,4 & 52,2 \\
\hline Lojas virtuais & 11,8 & 11,1 & 19,1 & 15,3 & 17,3 & 12,8 & 15,2 & 17,4 \\
\hline Sites de provedor & 55,9 & 49,2 & 46,1 & 62,5 & 45,7 & 64,1 & 57,6 & 69,6 \\
\hline Sites de busca/ pesquisa & 67,6 & 70,2 & 70,8 & 72,2 & 63,0 & 71,8 & 71,7 & 73,9 \\
\hline Sites de revistas & 41,2 & 32,1 & 34,8 & 33,3 & 35,8 & 25,6 & 30,4 & 26,1 \\
\hline Sites de jornais & 44,1 & 29,8 & 38,2 & 61,1 & 45,7 & 43,6 & 44,6 & 52,2 \\
\hline Utilidade pública & 32,4 & 25,4 & 33,7 & 45,8 & 33,3 & 61,5 & 34,8 & 39,1 \\
\hline Sites de empresas & 14,7 & 10,3 & 19,1 & 33,3 & 25,9 & 35,9 & 23,9 & 26,1 \\
\hline Sites de músicas & 47,1 & 56,0 & 55,1 & 50,0 & 51,9 & 56,4 & 53,3 & 26,1 \\
\hline Sites de esportes & 38,2 & 37,3 & 41,6 & 38,9 & 30,9 & 30,8 & 38,0 & 43,5 \\
\hline Sites infantis & 20,6 & 11,5 & 9,0 & 6,9 & 4,9 & 2,6 & 12,0 & 8,7 \\
\hline Outros tipos de sites (específicos) & 8,8 & 8,7 & 4,5 & 8,3 & 16,0 & 12,8 & 9,8 & 8,7 \\
\hline
\end{tabular}

Com o aumento da renda, diminui o interesse de cursos pela Internet. Analogamente, quanto menor a renda, maior é a expectativa de que, através da Internet, se possa fazer algum curso para o qual não se tem recursos de acesso ao vivo. 
Tabela 3.6.8: Predisposição para a realização de curso pela Internet, entre os usuários de microcomputador, por faixa de renda

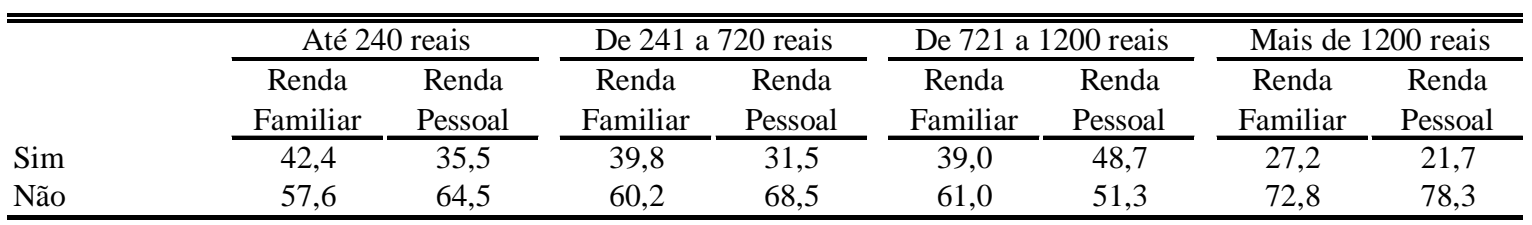

Como era de se esperar, quanto mais alta a renda, maior é a utilização da Internet para fazer negócios:

Tabela 3.6.9: Utilização da Internet para fazer negócios entre os moradores que utilizam computador por faixa de renda

\begin{tabular}{|c|c|c|c|c|c|c|c|c|}
\hline & \multicolumn{2}{|c|}{ Até 240 reais } & \multicolumn{2}{|c|}{ De 241 a 720 reais } & \multicolumn{2}{|c|}{ De 721 a 1200 reais } & \multicolumn{2}{|c|}{ Mais de 1200 reais } \\
\hline & $\begin{array}{c}\text { Renda } \\
\text { Familiar }\end{array}$ & $\begin{array}{l}\text { Renda } \\
\text { Pessoal }\end{array}$ & $\begin{array}{c}\text { Renda } \\
\text { Familiar }\end{array}$ & $\begin{array}{l}\text { Renda } \\
\text { Pessoal }\end{array}$ & $\begin{array}{c}\text { Renda } \\
\text { Familiar }\end{array}$ & $\begin{array}{l}\text { Renda } \\
\text { Pessoal }\end{array}$ & $\begin{array}{c}\text { Renda } \\
\text { Familiar }\end{array}$ & $\begin{array}{l}\text { Renda } \\
\text { Pessoal }\end{array}$ \\
\hline Sim & 17,6 & 13,5 & 15,9 & 27,4 & 26,8 & 35,9 & 35,9 & 52,2 \\
\hline Não & 82,4 & 86,5 & 84,1 & 72,6 & 73,2 & 64,1 & 64,1 & 47,8 \\
\hline
\end{tabular}

$\mathrm{Na}$ medida em que aumenta a renda, também aumenta a freqüência de utilização da Internet para movimentação bancária e compras.

Tabela 3.6.10: Tipo de negócio realizado na Internet, segundo a faixa de renda

\begin{tabular}{|c|c|c|c|c|c|c|c|c|}
\hline & \multicolumn{2}{|c|}{ Até 240 reais } & \multicolumn{2}{|c|}{ De 241 a 720 reais } & \multicolumn{2}{|c|}{ De 721 a 1200 reais } & \multicolumn{2}{|c|}{ Mais de 1200 reais } \\
\hline & Renda & Renda & Renda & Renda & Renda & Renda & Renda & Renda \\
\hline & Familiar & Pessoal & Familiar & Pessoal & Familiar & Pessoal & Familiar & Pessoal \\
\hline Compra & 33,3 & 35,3 & 7,7 & 10,5 & 27,3 & 35,7 & 43,8 & 53,8 \\
\hline Venda & - & 8,8 & 7,7 & 15,8 & 22,7 & 14,3 & 6,3 & 15,4 \\
\hline Informação de preços & 16,7 & 32,4 & 46,2 & 21,1 & 22,7 & 7,1 & 31,3 & 23,1 \\
\hline Pagamento de contas & 33,3 & 29,4 & 46,2 & 15,8 & 13,6 & 57,1 & 34,4 & 38,5 \\
\hline Movimentação bancária & 50,0 & 17,6 & 23,1 & 42,1 & 27,3 & 42,9 & 53,1 & 38,5 \\
\hline Outros & 33,3 & 14,7 & - & 10,5 & 13,6 & 7,1 & 6,3 & 7,7 \\
\hline
\end{tabular}

$\mathrm{Na}$ medida em que aumenta a renda, torna-se mais freqüente o acesso de sites em outras línguas, o que era de se esperar pois, geralmente, há uma forte correlação entre renda e escolaridade: 
Tabela 3.6.11: Acesso a sites de textos em outras línguas, entre moradores que utilizam microcomputador, por faixa de renda

\begin{tabular}{|c|c|c|c|c|c|c|c|c|}
\hline & \multicolumn{2}{|c|}{ Até 240 reais } & \multicolumn{2}{|c|}{ De 241 a 720 reais } & \multicolumn{2}{|c|}{ De 721 a 1200 reais } & \multicolumn{2}{|c|}{ Mais de 1200 reais } \\
\hline & Renda & Renda & Renda & Renda & Renda & Renda & Renda & Renda \\
\hline & Familiar & Pessoal & Familiar & Pessoal & Familiar & Pessoal & Familiar & Pessoa \\
\hline Sim & 11,8 & 19,8 & 15,9 & 9,6 & 19,5 & 25,6 & 22,8 & 13,0 \\
\hline Não & 88,2 & 80,2 & 84,1 & 90,4 & 80,5 & 74,4 & 77,2 & 87,0 \\
\hline
\end{tabular}

Como vemos no gráfico a seguir, a aprendizagem de outras línguas em cursos privados aumenta com o nível de renda. Vale ressaltar, entretanto, que a amostra do grupo de famílias com mais de 1.200 reais de renda não é representativa para este indicador, o que possivelmente produz o desvio da tendência.

Tabela 3.6.12: Local onde aprendeu outras línguas, por faixa de renda

\begin{tabular}{|c|c|c|c|c|}
\hline & Até 240 reais & $\begin{array}{l}\text { De } 241 \text { a } \\
720 \text { reais }\end{array}$ & $\begin{array}{c}\text { De } 721 \text { a } \\
1200 \text { reais }\end{array}$ & $\begin{array}{c}\text { Mais de } \\
1200 \text { reais }\end{array}$ \\
\hline Curso & 25,0 & 33,3 & 46,7 & 47,4 \\
\hline Escola & 75,0 & 33,3 & 26,7 & 31,6 \\
\hline Sozinho & - & 16,7 & 13,3 & 10,5 \\
\hline $\mathrm{Na}$ própria Internet & - & 8,3 & 6,7 & 5,3 \\
\hline De outra maneira & - & 8,3 & 6,7 & 5,3 \\
\hline
\end{tabular}

Nos setores de renda mais alta, o uso de e-mail apresenta um claro incremento.

Tabela 3.6.13: Interesse em contatar pessoas de outros países, pela Internet, entre moradores que utilizam microcomputador, por faixa de renda

\begin{tabular}{|c|c|c|c|c|c|c|c|c|}
\hline & \multicolumn{2}{|c|}{ Até 240 reais } & \multicolumn{2}{|c|}{ De 241 a 720 reais } & \multicolumn{2}{|c|}{ De 721 a 1200 reais } & \multicolumn{2}{|c|}{ Mais de 1200 reais } \\
\hline & $\begin{array}{c}\text { Renda } \\
\text { Familiar }\end{array}$ & $\begin{array}{l}\text { Renda } \\
\text { Pessoal }\end{array}$ & $\begin{array}{c}\text { Renda } \\
\text { Familiar }\end{array}$ & $\begin{array}{l}\text { Renda } \\
\text { Pessoal }\end{array}$ & $\begin{array}{c}\text { Renda } \\
\text { Familiar }\end{array}$ & $\begin{array}{c}\text { Renda } \\
\text { Pessoal }\end{array}$ & $\begin{array}{c}\text { Renda } \\
\text { Familiar }\end{array}$ & $\begin{array}{l}\text { Renda } \\
\text { Pessoal }\end{array}$ \\
\hline Sim & 41,2 & 38,1 & 36,4 & 41,1 & 54,9 & 64,1 & 62,0 & 78,3 \\
\hline Não & 58,8 & 61,9 & 63,6 & 58,9 & 45,1 & 35,9 & 38,0 & 21,7 \\
\hline
\end{tabular}

Considerando-se que o e-mail está associado ao trabalho, e que a freqüência de sua utilização aumenta com a renda pessoal, levamos em consideração apenas esse tipo de renda. 
Tabela 3.6.15: Utilização de e-mail, por faixa de renda

\begin{tabular}{|c|c|c|c|c|}
\hline & $\begin{array}{c}\text { Até } 240 \\
\text { reais }\end{array}$ & $\begin{array}{l}\text { De } 241 \text { a } \\
720 \text { reais }\end{array}$ & $\begin{array}{c}\text { De } 721 \text { a } \\
1200 \text { reais }\end{array}$ & $\begin{array}{c}\text { Mais de } \\
1200 \text { reais }\end{array}$ \\
\hline $1 \mathrm{vez}$ ao dia & 20,8 & 30,0 & 24,0 & 42,1 \\
\hline Mais de 1 vez ao dia & 8,3 & 13,3 & 20,0 & 21,1 \\
\hline 1 vez por semana & 29,2 & 33,3 & 32,0 & 15,8 \\
\hline Mais de 1 vez por semana & 22,9 & 16,7 & 12,0 & 10,5 \\
\hline 1 vez ao mês & 12,5 & 6,7 & 8,0 & 5,3 \\
\hline Nunca & 6,3 & - & 4,0 & 5,3 \\
\hline
\end{tabular}

Quanto maior o nível de renda, maior a associação do uso do e-mail a trabalho:

Tabela 3.6.16: Objetivo da utilização do e-mail, por faixa de renda

\begin{tabular}{|c|c|c|c|c|c|c|c|c|}
\hline & \multicolumn{2}{|c|}{ Até 240 reais } & \multicolumn{2}{|c|}{ De 241 a 720 reais } & \multicolumn{2}{|c|}{ De 721 a 1200 reais } & \multicolumn{2}{|c|}{ Mais de 1200 reais } \\
\hline & Renda & Renda & Renda & Renda & Renda & Renda & Renda & Renda \\
\hline & Familiar & Pessoal & Familiar & Pessoal & Familiar & Pessoal & Familiar & Pessoal \\
\hline Somente paratrabalho & 7,1 & 5,3 & 9,4 & 13,3 & 9,1 & 12,0 & 10,9 & 15,8 \\
\hline Mais para trabalho do que $\mathrm{p}$ / lazer & 7,1 & 8,5 & 12,5 & 10,0 & 11,4 & 20,0 & 12,7 & 15,8 \\
\hline Metade para trabalho metade $\mathrm{p} /$ lazer & 42,9 & 28,7 & 21,9 & 26,7 & 27,3 & 48,0 & 36,4 & 36,8 \\
\hline Mais para lazer do que $\mathrm{p} /$ trabalho & 7,1 & 13,8 & 12,5 & 23,3 & 27,3 & 12,0 & 14,5 & 10,5 \\
\hline Somente para lazer & 35,7 & 43,6 & 43,8 & 26,7 & 25,0 & 8,0 & 25,5 & 21,1 \\
\hline
\end{tabular}

Novamente, é consensual a importância do conhecimento de informática para obter emprego:

Tabela 3.6.17: Opinião sobre a importância do domínio de informática na conquista de emprego, entre usuários de microcomputador, por faixa de renda

\begin{tabular}{|c|c|c|c|c|c|c|c|c|}
\hline & \multicolumn{2}{|c|}{ Até 240 reais } & \multicolumn{2}{|c|}{ De 241 a 720 reais } & \multicolumn{2}{|c|}{ De 721 a 1200 reais } & \multicolumn{2}{|c|}{ Mais de 1200 reais } \\
\hline & Renda & Renda & Renda & Renda & Renda & Renda & Renda & Renda \\
\hline & Familiar & Pessoal & Familiar & Pessoal & Familiar & Pessoal & Familiar & Pessoal \\
\hline Sim & 95,1 & 99,1 & 97,9 & 99,2 & 100,0 & 100,0 & 98,5 & 94,9 \\
\hline Não & 4,9 & 0,9 & 2,1 & 0,8 & - & - & 1,5 & 5,1 \\
\hline
\end{tabular}

\section{7 - Análise por faixa de instrução ${ }^{12}$}

Nas estatísticas a seguir, só levamos em consideração pessoas acima de 20 anos, de forma a eliminar o fator etário. Igualmente, unificamos os grupos com $3^{\circ}$ grau incompleto e completo, para obter um grupo estatisticamente representativo.

Como mostra o próximo gráfico, o fato de o entrevistado possuir $2^{\circ}$ grau completo e também curso universitário (completo ou não) faz enorme diferença, em termos de intensidade do uso do computador:

\footnotetext{
12 Todas as tabelas desta seção mostram percentuais relativos ao próprio grupo.
} 
Tabela3.7.1: Frequiência de utilização do computador, por faixa de instrução

\begin{tabular}{|c|c|c|c|c|c|}
\hline & $\begin{array}{c}1^{\circ} \text { grau } \\
\text { incompleto }\end{array}$ & $\begin{array}{l}1^{\circ} \text { grau } \\
\text { completo }\end{array}$ & $\begin{array}{c}2^{\circ} \text { grau } \\
\text { incompleto }\end{array}$ & $\begin{array}{l}2^{\circ} \text { grau } \\
\text { completo }\end{array}$ & $\begin{array}{c}3^{\circ} \text { grau } \\
\text { incompleto/ } \\
\text { completo }\end{array}$ \\
\hline Diariamente & 22,3 & 21,6 & 27,9 & 36,5 & 62,1 \\
\hline Pelo menos uma vez por semana & 21,2 & 22,2 & 25,9 & 27,2 & 19,0 \\
\hline Eventualmente & 13,4 & 9,9 & 13,6 & 13,0 & 6,9 \\
\hline Raramente & 43,0 & 46,3 & 32,7 & 23,3 & 12,1 \\
\hline
\end{tabular}

Não se observa um padrão definido sobre a aprendizagem do uso de computador, entre as diferentes faixas de instrução:

Tabela 3.7.2: Maneira como aprendeu a usar o microcomputador, por faixa de instrução

\begin{tabular}{|c|c|c|c|c|c|}
\hline & $\begin{array}{c}1^{\circ} \text { grau } \\
\text { incompleto }\end{array}$ & $\begin{array}{l}1^{\circ} \text { grau } \\
\text { completo }\end{array}$ & $\begin{array}{c}2^{\circ} \text { grau } \\
\text { incompleto }\end{array}$ & $\begin{array}{l}2^{\circ} \text { grau } \\
\text { completo }\end{array}$ & $\begin{array}{c}3^{\circ} \text { grau } \\
\text { incompleto/ } \\
\text { completo }\end{array}$ \\
\hline Sozinho, por tentativas & 17,6 & 15,9 & 14,9 & 11,8 & 20,7 \\
\hline Sozinho, com ajuda dos manuais & 2,7 & 1,2 & 1,4 & 2,5 & 1,7 \\
\hline Com orientação, no trabalho & 14,8 & 7,9 & 9,5 & 10,3 & 10,3 \\
\hline Com ajuda de amigos & 18,7 & 16,5 & 7,4 & 7,6 & 6,9 \\
\hline Em cursos especializados & 41,8 & 55,5 & 62,8 & 64,9 & 58,6 \\
\hline De outra maneira & 4,4 & 3,0 & 4,1 & 2,9 & 1,7 \\
\hline
\end{tabular}

Quanto mais elevado o nível educacional, mais variados e amplos são os programas utilizados:

Tabela 3.7.3: Tipos de programas mais utilizados, por faixa de instrução

\begin{tabular}{|c|c|c|c|c|c|}
\hline & $\begin{array}{c}1^{\circ} \text { grau } \\
\text { incompleto }\end{array}$ & $\begin{array}{c}1^{\mathrm{o}} \text { grau } \\
\text { completo }\end{array}$ & $\begin{array}{c}2^{\circ} \text { grau } \\
\text { incompleto }\end{array}$ & $\begin{array}{c}2^{\circ} \text { grau } \\
\text { completo }\end{array}$ & $\begin{array}{c}3^{\circ} \text { grau } \\
\text { incompleto/ } \\
\text { completo }\end{array}$ \\
\hline Processadores de texto & 58,4 & 75,8 & 81,1 & 84,8 & 91,4 \\
\hline Planilhas eletrônicas & 41,6 & 48,4 & 43,9 & 61,3 & 74,1 \\
\hline Programas de apresentação & 12,9 & 24,2 & 29,7 & 41,4 & 51,7 \\
\hline Linguagens de programação & 1,7 & 5,0 & 5,4 & 7,1 & 13,8 \\
\hline Jogos & 49,4 & 47,8 & 48,6 & 44,6 & 36,2 \\
\hline Outros & 9,0 & 7,5 & 8,8 & 4,7 & 10,3 \\
\hline
\end{tabular}

Da mesma forma, quanto mais alto o nível educacional, maiores são as chances de o usuário de microcomputador usar a Internet, sendo que entre os que têm curso superior (completo ou não), esse resultado se aproxima de cem por cento: 
Tabela 3.7.4: Utilização da Internet, por faixa de instrução

\begin{tabular}{|c|c|c|c|c|c|}
\hline & $\begin{array}{c}1^{\circ} \mathrm{grau} \\
\text { incompleto }\end{array}$ & $\begin{array}{l}1^{\circ} \text { grau } \\
\text { completo }\end{array}$ & $\begin{array}{c}2^{\circ} \mathrm{grau} \\
\text { incompleto }\end{array}$ & $\begin{array}{c}2^{\circ} \text { grau } \\
\text { completo }\end{array}$ & $\begin{array}{c}3^{\circ} \text { grau } \\
\text { incompleto/ } \\
\text { completo }\end{array}$ \\
\hline Sim & 39,1 & 46,6 & 50,7 & 67,8 & 84,2 \\
\hline Não & 60,9 & 53,4 & 49,3 & 32,2 & 15,8 \\
\hline
\end{tabular}

A falta de local é a principal razão para os diversos grupos não acessarem a Internet.

Tabela 3.7.5: Motivos para não acessar a Internet, por faixa de instrução

\begin{tabular}{|c|c|c|c|c|c|}
\hline & $\begin{array}{c}1^{\circ} \mathrm{grau} \\
\text { incompleto }\end{array}$ & $\begin{array}{c}1^{\circ} \text { grau } \\
\text { completo }\end{array}$ & $\begin{array}{c}2^{\circ} \text { grau } \\
\text { incompleto }\end{array}$ & $\begin{array}{c}2^{\circ} \text { grau } \\
\text { completo }\end{array}$ & $\begin{array}{c}3^{\circ} \text { grau } \\
\text { incompleto/ } \\
\text { completo }\end{array}$ \\
\hline Falta de local onde acessar & 61,8 & 63,1 & 68,1 & 71,0 & 77,8 \\
\hline Não tem interesse & 5,5 & 13,1 & 12,5 & 9,9 & - \\
\hline Acha muito complicado & 14,5 & 9,5 & 5,6 & 3,8 & - \\
\hline Acha caro & 4,5 & 7,1 & 9,7 & 6,9 & - \\
\hline Não tem tempo & 13,6 & 7,1 & 4,2 & 8,4 & 22,2 \\
\hline
\end{tabular}

A freqüência de acesso à Internet aumenta com o nível de escolaridade:

Tabela 3.7.6: Frequiência de acesso à Internet, por faixa de instrução

\begin{tabular}{|c|c|c|c|c|c|}
\hline & $\begin{array}{c}1^{\circ} \text { grau } \\
\text { incompleto }\end{array}$ & $\begin{array}{c}1^{\circ} \text { grau } \\
\text { completo }\end{array}$ & $\begin{array}{c}2^{\circ} \text { grau } \\
\text { incompleto }\end{array}$ & $\begin{array}{c}2^{\circ} \text { grau } \\
\text { completo }\end{array}$ & $\begin{array}{c}3^{\circ} \text { grau } \\
\text { incompleto/ } \\
\text { completo }\end{array}$ \\
\hline Mais de uma vez ao dia & 16,2 & 5,3 & 12,5 & 18,7 & 33,3 \\
\hline $1 \mathrm{vez}$ ao dia & 11,8 & 15,8 & 12,5 & 11,7 & 25,0 \\
\hline Mais de uma vez por semana & 17,6 & 19,7 & 27,8 & 27,5 & 25,0 \\
\hline $1 \mathrm{vez}$ por semana & 33,8 & 27,6 & 27,8 & 24,5 & 12,5 \\
\hline 1 vez por mês & 20,6 & 31,6 & 19,4 & 17,6 & 4,2 \\
\hline
\end{tabular}

Com o aumento do nível de escolaridade, os sites de busca, utilidade pública e empresas tendem a ser mais visitados. Quanto aos outros sites, não há tendências significativas. 
Tabela 3.7.7: Tipos de sites mais acessados, por faixa de instrução

\begin{tabular}{|c|c|c|c|c|c|}
\hline & $\begin{array}{c}1^{\circ} \mathrm{grau} \\
\text { incompleto }\end{array}$ & $\begin{array}{c}1^{\circ} \text { grau } \\
\text { completo }\end{array}$ & $\begin{array}{c}2^{\circ} \text { grau } \\
\text { incompleto }\end{array}$ & $\begin{array}{c}2^{\circ} \text { grau } \\
\text { completo }\end{array}$ & $\begin{array}{c}3^{\circ} \text { grau } \\
\text { incompleto/ } \\
\text { completo }\end{array}$ \\
\hline Webmail & 34,3 & 23,7 & 36,0 & 37,3 & 57,4 \\
\hline Lojas virtuais & 13,4 & 17,1 & 17,3 & 14,0 & 14,9 \\
\hline Sites de provedor & 46,3 & 47,4 & 53,3 & 46,5 & 68,1 \\
\hline Sites de busca/ pesquisa & 55,2 & 63,2 & 70,7 & 69,7 & 78,7 \\
\hline Sites de revistas & 29,9 & 38,2 & 37,3 & 31,7 & 25,5 \\
\hline Sites de jornais & 38,8 & 48,7 & 50,7 & 49,1 & 44,7 \\
\hline Utilidade pública & 22,4 & 25,0 & 32,0 & 44,3 & 59,6 \\
\hline Sites de empresas & 23,9 & 21,1 & 24,0 & 30,3 & 44,7 \\
\hline Sites de músicas & 44,8 & 57,9 & 48,0 & 42,4 & 29,8 \\
\hline Sites de esportes & 23,9 & 39,5 & 40,0 & 32,8 & 36,2 \\
\hline Sites infantis & 4,5 & 13,2 & 5,3 & 7,4 & 8,5 \\
\hline Outros tipos de sites (específicos) & 10,4 & 11,8 & 16,0 & 10,3 & 17,0 \\
\hline
\end{tabular}

Não há diferenças significativas no que se refere à utilização da Internet para a realização de cursos.

Tabela 3.7.8: Predisposição para a realização de curso pela Internet, entre os moradores que utilizam microcomputador, por faixa de instrução

\begin{tabular}{|c|c|c|c|c|c|}
\hline & $\begin{array}{c}1^{\circ} \text { grau } \\
\text { incompleto }\end{array}$ & $\begin{array}{c}1^{\circ} \text { grau } \\
\text { completo }\end{array}$ & $\begin{array}{c}2^{\circ} \text { grau } \\
\text { incompleto }\end{array}$ & $\begin{array}{c}2^{\circ} \text { grau } \\
\text { completo }\end{array}$ & $\begin{array}{c}3^{\circ} \text { grau } \\
\text { incompleto/ } \\
\text { completo }\end{array}$ \\
\hline Sim & 39,7 & 35,5 & 45,2 & 32,4 & 39,6 \\
\hline Não & 60,3 & 64,5 & 54,8 & 67,6 & 60,4 \\
\hline
\end{tabular}

A utilização da Internet para realizar negócios aumenta significativamente, na medida em que o nível de escolaridade é mais alto:

Tabela 3.7.9: Utilização da Internet para fazer negócios, entre os moradores que utilizam Computador, por faixa de instrução

\begin{tabular}{|c|c|c|c|c|c|}
\hline & $\begin{array}{c}1^{\mathrm{o}} \text { grau } \\
\text { incompleto }\end{array}$ & $\begin{array}{c}1^{\circ} \text { grau } \\
\text { completo }\end{array}$ & $\begin{array}{c}2^{\circ} \text { grau } \\
\text { incompleto }\end{array}$ & $\begin{array}{c}2^{\circ} \text { grau } \\
\text { completo }\end{array}$ & $\begin{array}{c}3^{\circ} \text { grau } \\
\text { incompleto/ } \\
\text { completo }\end{array}$ \\
\hline Sim & 22,4 & 29,3 & 35,1 & 33,7 & 47,9 \\
\hline Não & 77,6 & 70,7 & 64,9 & 66,3 & 52,1 \\
\hline
\end{tabular}

O principal diferencial na utilização comercial da Internet se refere à movimentação bancária, que aumenta significativamente entre as pessoas com níveis de escolaridade mais altos. 
Tabela 3.7.10: Tipo de negócio realizado na Internet, segundo a faixa de instrução

\begin{tabular}{|c|c|c|c|c|c|}
\hline & $\begin{array}{c}1^{\circ} \text { grau } \\
\text { incompleto }\end{array}$ & $\begin{array}{l}1^{\circ} \text { grau } \\
\text { completo }\end{array}$ & $\begin{array}{c}2^{\circ} \text { grau } \\
\text { incompleto }\end{array}$ & $\begin{array}{l}2^{\circ} \text { grau } \\
\text { completo }\end{array}$ & $\begin{array}{c}3^{\circ} \text { grau } \\
\text { incompleto/ } \\
\text { completo }\end{array}$ \\
\hline Compra & 46,7 & 30,4 & 26,9 & 47,3 & 50,0 \\
\hline Venda & 13,3 & 17,4 & 15,4 & 8,6 & 12,5 \\
\hline Informação de preços & 20,0 & 30,4 & 46,2 & 25,8 & 16,7 \\
\hline Pagamento de contas & 33,3 & 34,8 & 30,8 & 28,0 & 29,2 \\
\hline Movimentação bancária & 13,3 & 26,1 & 38,5 & 20,4 & 62,5 \\
\hline Outros & 20,0 & 13,0 & 3,8 & 7,5 & 12,5 \\
\hline
\end{tabular}

A utilização de sites em outras línguas também apresenta uma mudança bastante significativa, nos grupos com níveis mais altos de escolaridade:

Tabela 3.7.11: Acesso a sites de textos em outras línguas, entre moradores que utilizam microcomputador, por faixa de instrução

\begin{tabular}{|c|c|c|c|c|c|}
\hline & $\begin{array}{c}1^{\mathrm{o}} \mathrm{grau} \\
\text { incompleto }\end{array}$ & $\begin{array}{c}1^{\mathrm{o}} \text { grau } \\
\text { completo }\end{array}$ & $\begin{array}{c}2^{\circ} \text { grau } \\
\text { incompleto }\end{array}$ & $\begin{array}{c}2^{\circ} \text { grau } \\
\text { completo }\end{array}$ & $\begin{array}{c}3^{\circ} \text { grau } \\
\text { incompleto/ } \\
\text { completo }\end{array}$ \\
\hline Sim & 8,8 & 8,0 & 10,8 & 17,6 & 37,5 \\
\hline Não & 91,2 & 92,0 & 89,2 & 82,4 & 62,5 \\
\hline
\end{tabular}

O interesse em contatar outros países através da Internet é bastante similar, nos diferentes níveis de escolaridade:

Tabela 3.7.12: Interesse em contatar outros países, entre moradores que utilizam microcomputador, por faixa de instrução

Os temas de interesse não apresentam uma tendência claramente definida: 
Tabela 3.7.13: Tipos de assuntos mais citados, por faixa de instrução

Como vivem, como é lá

Cultura, atualidade, informação

Bate-papo

Assuntos gerais

Música, jogos, esporte, lazer

Pesquisa, educação, línguas

Religião

Política, economia, emprego

Turismo, segurança

Sociedade, saúde, pobreza

Informática, tecnologia

Outroas

\begin{tabular}{|c|c|c|c|c|}
\hline $\begin{array}{c}1^{\circ} \text { grau } \\
\text { incompleto }\end{array}$ & $\begin{array}{c}1^{\circ} \text { grau } \\
\text { completo }\end{array}$ & $\begin{array}{c}2^{\circ} \text { grau } \\
\text { incompleto }\end{array}$ & $\begin{array}{c}2^{\mathrm{o}} \text { grau } \\
\text { completo }\end{array}$ & $\begin{array}{c}3^{\circ} \text { grau } \\
\text { incompleto/ } \\
\text { completo }\end{array}$ \\
\hline 13,9 & 15,7 & 12,8 & 10,5 & 5,3 \\
\hline 27,8 & 11,8 & 29,8 & 27,4 & 34,2 \\
\hline- & 3,9 & - & 2,1 & 2,6 \\
\hline 25,0 & 17,6 & 12,8 & 21,6 & 13,2 \\
\hline 8,3 & 2,0 & 2,1 & 3,7 & 2,6 \\
\hline 5,6 & 2,0 & 4,3 & 3,2 & 5,3 \\
\hline 2,8 & 2,0 & 4,3 & 3,2 & 5,3 \\
\hline 8,3 & 15,7 & 19,1 & 13,2 & 5,3 \\
\hline 5,6 & 3,9 & 2,1 & 2,1 & 2,6 \\
\hline- & 15,7 & 6,4 & 8,9 & 13,2 \\
\hline- & 5,9 & 6,4 & 0,5 & 7,9 \\
\hline 2,8 & 3,9 & - & 3,7 & 2,6 \\
\hline
\end{tabular}

A freqüência do uso de e-mail aumenta com o nível de escolaridade:

Tabela 3.7.14: Utilização de e-mail, por faixa de instrução

\begin{tabular}{|c|c|c|c|c|c|}
\hline & $\begin{array}{c}1^{\mathrm{o}} \text { grau } \\
\text { incompleto }\end{array}$ & $\begin{array}{l}1^{\circ} \text { grau } \\
\text { completo }\end{array}$ & $\begin{array}{c}2^{\circ} \mathrm{grau} \\
\text { incompleto }\end{array}$ & $\begin{array}{c}2^{\circ} \text { grau } \\
\text { completo }\end{array}$ & $\begin{array}{c}3^{\circ} \text { grau } \\
\text { incompleto/ } \\
\text { completo }\end{array}$ \\
\hline Sim & 38,2 & 47,4 & 48,6 & 58,7 & 81,3 \\
\hline Não & 61,8 & 52,6 & 51,4 & 41,3 & 18,8 \\
\hline
\end{tabular}

Por outro lado, a intensidade de verificação do e-mail não apresenta um padrão definido:

Tabela 3.7.15: Freqüência de verificação do e-mail, por faixa de instrução

\begin{tabular}{|c|c|c|c|c|c|}
\hline & $\begin{array}{c}1^{\circ} \mathrm{grau} \\
\text { incompleto }\end{array}$ & $\begin{array}{l}1^{\circ} \text { grau } \\
\text { completo }\end{array}$ & $\begin{array}{c}2^{\circ} \text { grau } \\
\text { incompleto }\end{array}$ & $\begin{array}{l}2^{\circ} \text { grau } \\
\text { completo }\end{array}$ & $\begin{array}{c}3^{\circ} \text { grau } \\
\text { incompleto/ } \\
\text { completo }\end{array}$ \\
\hline Mais de 1 vez ao dia & 26,9 & 16,2 & 34,3 & 18,6 & 27,5 \\
\hline Uma vez ao dia & 23,1 & 18,9 & 14,3 & 15,5 & 25,0 \\
\hline Uma vez por semana & 23,1 & 21,6 & 17,1 & 25,5 & 17,5 \\
\hline Mais de 1 vez por semana & 15,4 & 16,2 & 20 & 24,2 & 20,0 \\
\hline Uma vez ao mês & 7,7 & 16,2 & 8,6 & 9,9 & 5,0 \\
\hline Nunca & 3,8 & 10,8 & 5,7 & 6,2 & 5,0 \\
\hline
\end{tabular}

O mesmo se observa quanto ao uso da Internet para conhecer pessoas, ou quanto ao nível socioeconômico e à utilidade dos contatos feitos pela Internet, como mostram as tabelas a seguir: 
Tabela 3.7.16: Conhecimento de pessoas pela Internet, por faixa de instrução

\begin{tabular}{|c|c|c|c|c|c|}
\hline & $\begin{array}{c}1^{\circ} \text { grau } \\
\text { incompleto }\end{array}$ & $\begin{array}{c}1^{\circ} \text { grau } \\
\text { completo }\end{array}$ & $\begin{array}{c}2^{\circ} \text { grau } \\
\text { incompleto }\end{array}$ & $\begin{array}{c}2^{\circ} \text { grau } \\
\text { completo }\end{array}$ & $\begin{array}{c}3^{\circ} \text { grau } \\
\text { incompleto/ } \\
\text { completo }\end{array}$ \\
\hline Sim & 30,8 & 43,2 & 48,6 & 48,4 & 32,5 \\
\hline Não & 69,2 & 56,8 & 51,4 & 51,6 & 67,5 \\
\hline
\end{tabular}

Tabela 3.7.17: Nível socioeconômico das pessoas conhecidas na Internet, por faixa de instrução

\begin{tabular}{|c|c|c|c|c|c|}
\hline & $\begin{array}{c}1^{\circ} \mathrm{grau} \\
\text { incompleto }\end{array}$ & $\begin{array}{c}1^{\circ} \text { grau } \\
\text { completo }\end{array}$ & $\begin{array}{c}2^{\circ} \text { grau } \\
\text { incompleto }\end{array}$ & $\begin{array}{c}2^{\circ} \text { grau } \\
\text { completo }\end{array}$ & $\begin{array}{c}3^{\circ} \text { grau } \\
\text { incompleto/ } \\
\text { completo }\end{array}$ \\
\hline Nível socioeconômico mais alto & 33,3 & 60,0 & 50,0 & 49,3 & 40,0 \\
\hline Mesmo nível socioeconômico & 66,7 & 30,0 & 42,9 & 49,3 & 50,0 \\
\hline Nível socioeconômico mais baixo & - & 10,0 & 7,1 & 1,4 & 10,0 \\
\hline
\end{tabular}

Tabela 3.7.18: De que maneira as pessoas conhecidas pela Internet ajudaram você, por faixa de instrução

\begin{tabular}{|c|c|c|c|c|c|}
\hline & $\begin{array}{c}1^{\circ} \text { grau } \\
\text { incompleto }\end{array}$ & $\begin{array}{l}1^{\circ} \text { grau } \\
\text { completo }\end{array}$ & $\begin{array}{c}2^{\circ} \text { grau } \\
\text { incompleto }\end{array}$ & $\begin{array}{c}2^{\circ} \text { grau } \\
\text { completo }\end{array}$ & $\begin{array}{c}3^{\circ} \text { grau } \\
\text { incompleto/ } \\
\text { completo }\end{array}$ \\
\hline Indicação para trabalho & 12,5 & - & 13,3 & 8,2 & 18,2 \\
\hline Não obtenção de inf. s/ temas de meu interesse & 37,5 & 43,8 & 40,0 & 42,5 & 36,4 \\
\hline Essas pessoas me ajudaram em outras coisas & - & 12,5 & 20,0 & 5,5 & 18,2 \\
\hline Essas pessoas não me ajudaram em nada & 50,0 & 43,8 & 43,8 & 43,8 & 27,3 \\
\hline
\end{tabular}

No que se refere a participar em grupos de chats, são as pessoas de nível superior que apresentam um diferencial importante, para menos:

Tabela 3.7.19: Participação em chats, por faixa de instrução

\begin{tabular}{|c|c|c|c|c|c|}
\hline & $\begin{array}{c}1^{\circ} \text { grau } \\
\text { incompleto }\end{array}$ & $\begin{array}{c}1^{\circ} \text { grau } \\
\text { completo }\end{array}$ & $\begin{array}{c}2^{\circ} \text { grau } \\
\text { incompleto }\end{array}$ & $\begin{array}{c}2^{\circ} \text { grau } \\
\text { completo }\end{array}$ & $\begin{array}{c}3^{\circ} \text { grau } \\
\text { incompleto/ } \\
\text { completo }\end{array}$ \\
\hline Sim & 34,6 & 32,4 & 34,3 & 31,1 & 22,5 \\
\hline Não & 65,4 & 67,6 & 65,7 & 68,9 & 77,5 \\
\hline
\end{tabular}


No grupo com nível de escolaridade mais alto, aumenta a utilização do e-mail para trabalho. Segue-se o grupo com o mais baixo nível de escolaridade, o que pode indicar que, neste grupo, o contato com Internet e e-mail são estabelecidos em função do trabalho. Por outro lado, o gráfico indica que quanto mais alto o nível de instrução, menos se usa o e-mail para lazer:

Tabela 3.7.20: Objetivo da utilização de e-mail, por faixa de instrução

\begin{tabular}{|c|c|c|c|c|c|}
\hline & $\begin{array}{c}1^{\circ} \text { grau } \\
\text { incompleto }\end{array}$ & $\begin{array}{c}1^{\mathrm{o}} \text { grau } \\
\text { completo }\end{array}$ & $\begin{array}{c}2^{\circ} \text { grau } \\
\text { incompleto }\end{array}$ & $\begin{array}{c}2^{\circ} \text { grau } \\
\text { completo }\end{array}$ & $\begin{array}{c}3^{\circ} \text { grau } \\
\text { incompleto/ } \\
\text { completo }\end{array}$ \\
\hline Somente para trabalho & 16,0 & 11,4 & 12,1 & 12,8 & 23,1 \\
\hline Mais para trabalho do que $\mathrm{p} /$ lazer & 20,0 & 14,3 & 6,1 & 17,9 & 23,1 \\
\hline Metade para o trabalho metade $\mathrm{p} /$ lazer & 16,0 & 34,3 & 24,2 & 37,8 & 43,6 \\
\hline Mais para o lazer do que $\mathrm{p} /$ trabalho & 12,0 & 8,6 & 30,3 & 16,7 & 2,6 \\
\hline Somente para lazer & 36,0 & 31,4 & 27,3 & 14,7 & 7,7 \\
\hline
\end{tabular}

Novamente é consensual a importância do conhecimento de computação para obtenção de emprego:

Tabela 3.7.21: Opinião sobre a importância do domínio de informática na conquista de emprego, entre usuários de microcomputador, por faixa de instrução

\begin{tabular}{|c|c|c|c|c|c|}
\hline & $\begin{array}{c}1^{\mathrm{o}} \text { grau } \\
\text { incompleto }\end{array}$ & $\begin{array}{c}1^{\circ} \text { grau } \\
\text { completo }\end{array}$ & $\begin{array}{c}2^{\circ} \text { grau } \\
\text { incompleto }\end{array}$ & $\begin{array}{c}2^{\circ} \text { grau } \\
\text { completo }\end{array}$ & $\begin{array}{c}3^{\circ} \text { grau } \\
\text { incompleto/ } \\
\text { completo }\end{array}$ \\
\hline Sim & 98,9 & 97,5 & 100,0 & 99,0 & 98,2 \\
\hline Não & 1,1 & 2,5 & - & 1,0 & 1,8 \\
\hline
\end{tabular}

Entre as pessoas com nível de escolaridade mais alto, o uso do computador é parte normal do trabalho, mas ele também representa uma exigência para mais de metade dos grupos de outros níveis de escolaridade: 
Tabela 3.7.22: Como o domínio de computação ajudou na obtenção de emprego, por faixa de instrução

\begin{tabular}{|c|c|c|c|c|c|}
\hline & $\begin{array}{c}1^{\circ} \text { grau } \\
\text { incompleto }\end{array}$ & $\begin{array}{l}1^{\circ} \text { grau } \\
\text { completo }\end{array}$ & $\begin{array}{c}2^{\circ} \text { grau } \\
\text { incompleto }\end{array}$ & $\begin{array}{l}2^{\circ} \text { grau } \\
\text { completo }\end{array}$ & $\begin{array}{c}3^{\circ} \text { grau } \\
\text { incompleto/ } \\
\text { completo }\end{array}$ \\
\hline Através de informações & 9,1 & 18,6 & 20,4 & $\overline{13,4}$ & 2,9 \\
\hline Na hora da entrevista & 29,5 & 20,9 & 20,4 & 23,9 & 20,6 \\
\hline Exigência do trabalho & 56,8 & 53,5 & 57,4 & 60,2 & 73,5 \\
\hline Outros motivos & 4,5 & 7,0 & 1,9 & 2,5 & 2,9 \\
\hline
\end{tabular}

\section{8 - Análise por tipo de escola}

As análises em relação à educação também são feitas por tipo de escola, levando em consideração pessoas até 20 anos.

Entre os entrevistados menores de 20 anos, a metade dos que freqüentam instituições privadas usa computador diariamente. Este número cai para metade nos que freqüentam escola pública. Por sua vez, entre os que usam computador raramente, $8.3 \%$ freqüentam escolas privadas e $25.1 \%$, escolas públicas:

Tabela3.8.1: Freqüência de utilização do computador, por tipo de escola

\begin{tabular}{lccc}
\hline \hline & Pública & Privada \\
\cline { 2 - 2 } Diariamente & 24,1 & & 50,0 \\
Pelo menos uma vez por semana & 34,2 & & 30,6 \\
Eventualmente & 16,6 & 11,1 \\
Raramente & 25,1 & 8,3 \\
\hline
\end{tabular}

Observamos que existe uma correlação entre o tipo de escola freqüentada, renda e computador no domicílio. 
Tabela 3.8.2: Faixa de renda, por tipo de escola

\begin{tabular}{lcc}
\hline \hline & Pública & Privada \\
\cline { 2 - 2 } Até 240 reais & 15,0 & 5,9 \\
De 241 a 720 reais & 39,4 & 23,5 \\
De 721 a 1200 reais & 30,7 & 17,6 \\
Mais de 1200 reais & 15,0 & 52,9 \\
\hline
\end{tabular}

Tabela 3.8.3: Posse de microcomputador, por tipo de escola

\begin{tabular}{lccc}
\hline \hline & Pública & & Privada \\
\cline { 2 - 3 } Tem computador no domicílio & 25,8 & 60,0 \\
Não tem computador no domicílio & 74,2 & 40,0 \\
\hline
\end{tabular}

$\mathrm{Na}$ há maiores diferenças em relação ao caminho para aprender a usar o microcomputador, embora entre os freqüentadores de escola pública o uso mais frequiente de cursos especializados expresse um menor percentual de pessoas com microcomputador no domicílio:

Tabela 3.8.4: Maneira como aprendeu usar o microcomputador, por tipo de escola

Sozinho, por tentativas

Sozinho, com ajuda dos manuais

Com orientação, no trabalho

Com ajuda de amigos

Em cursos especializados

De outra maneira

\begin{tabular}{ccc}
\hline \hline Pública & & Privada \\
\cline { 1 - 1 } 16,6 & & 19,4 \\
1,0 & & 2,8 \\
0,5 & & - \\
12,4 & & 16,7 \\
64,5 & & 52,8 \\
5,0 & & 8,3 \\
\hline
\end{tabular}

Os freqüentadores de escola privada apresentam uma maior diversidade e intensidade de uso de programas de computação:

Tabela 3.8.5: Tipos de programas mais utilizados, por tipo de escola

\begin{tabular}{lccc}
\hline \hline & Pública & Privada \\
\cline { 2 - 2 } Processadores de texto & 76,7 & & 97,2 \\
Planilhas eletrônicas & 40,4 & & 58,3 \\
Programas de apresentação gráfica & 28,0 & & 50,0 \\
Linguagens de programação & 2,7 & & 13,9 \\
Jogos & 68,0 & 72,2 \\
Outros & 2,7 & 2,8 \\
\hline
\end{tabular}

O diferencial entre usuários de Internet é muito grande, a favor dos que cursam escolas privadas: 
Tabela 3.8.6: Utilização da Internet, por tipo de escola

\begin{tabular}{lccc}
\hline & & \\
\cline { 2 - 3 } Sim & Pública & & Privada \\
\cline { 2 - 2 } Não & 65,3 & & 91,7 \\
\hline
\end{tabular}

O gráfico a seguir é desprezível em relação aos usuários de Internet de escolas privadas, representados em um universo ínfimo. Entre os alunos de escolas públicas, a falta de local é considerada o principal motivo para não se acessar a Internet :

Tabela 3.8.7: Motivos para não acessar a Internet, por tipo de escola

\begin{tabular}{|c|c|c|}
\hline & Pública & Privada \\
\hline Não possui local onde acessar & 59,4 & 33,3 \\
\hline Não possui interesse & 13,0 & - \\
\hline Acha muito complicado & 10,1 & - \\
\hline Caro & 7,2 & 33,3 \\
\hline Não tem tempo & 10,1 & 33,3 \\
\hline
\end{tabular}

A freqüência dos que usam Internet é mais intensa entre alunos de escolas privadas:

Tabela 3.8.8: Frequiência de acesso à Internet, por tipo de escola

\begin{tabular}{lccc}
\hline \hline & Pública & Privada \\
\cline { 2 - 2 } Mais de 1 vez ao dia & 8,8 & 6,1 \\
1 vez ao dia & 15,0 & 24,2 \\
1 vez por semana & 36,9 & 30,3 \\
Mais de 1 vez por semana & 25,0 & 33,3 \\
1 vez por mês & 14,2 & 6,1 \\
\hline
\end{tabular}

Os sites de busca e informações são mais utilizados pelos alunos de escolas privadas: 
Tabela 3.8.9: Tipos de sites mais acessados, por tipo de escola

\begin{tabular}{lccc}
\hline \hline & Pública & Privada \\
\cline { 2 - 2 } Webmail & 39,3 & & 33,3 \\
Lojas virtuais & 7,6 & & 12,1 \\
Sites de provedor & 49,2 & & 48,5 \\
Sites de busca / pesquisa & 70,6 & 81,8 \\
Sites de revista & 25,6 & 33,3 \\
Sites e jornais & 24,4 & 36,4 \\
Utilidades públicas & 14,5 & 12,1 \\
Sites de empresas & 6,1 & 15,2 \\
Sites de músicas & 60,3 & 57,6 \\
Sites de esportes & 41,2 & 24,2 \\
Sites infantis & 9,5 & 12,1 \\
Outros (específicos) & 11,8 & 3,0 \\
\hline
\end{tabular}

Os alunos de escolas públicas têm maior predisposição para fazer cursos pela Internet:

Tabela 3.8.10: Predisposição para a realização de curso pela Internet, entre os moradores que utilizam microcomputador, por tipo de escola

\begin{tabular}{llll}
\hline & & \\
\cline { 2 - 3 } Sim & Pública & & Privada \\
\cline { 2 - 3 } Não & 39,2 & & 27,3 \\
\hline
\end{tabular}

Como os alunos de escolas privadas têm maior renda, era de se esperar que uma porcentagem maior deles indicasse ter feito algum negócio pela Internet:

Tabela 3.8.11: Utilização da Internet para fazer negócios, entre os moradores que utilizam microcomputador, por tipo de escola

\begin{tabular}{|c|c|c|}
\hline & Pública & Privada \\
\hline Sim & 7,7 & 18,2 \\
\hline Não & 92,3 & 81,8 \\
\hline
\end{tabular}

Os alunos de escolas privadas usam um universo maior de instrumentos de e-negócios: 
Tabela 3.8.12: Tipo de negócio realizado na Internet, segundo o tipo de escola

\begin{tabular}{|c|c|c|}
\hline & Pública & Privada \\
\hline Compra & 25,0 & 33,3 \\
\hline Venda & 20,0 & 16,7 \\
\hline Informação de preços & 20,0 & 50,0 \\
\hline Pagamento de contas & 35,0 & - \\
\hline Movimentação bancária & 15,0 & 16,7 \\
\hline Outros & 15,0 & 16,7 \\
\hline
\end{tabular}

O percentual de alunos de escolas privadas que acessam sites em outras línguas é o dobro do de alunos de escolas públicas:

Tabela 3.8.13: Acesso a sites de textos em outras línguas, entre moradores que utilizam microcomputador, por tipo de escola

\begin{tabular}{lccc}
\hline & & \\
\cline { 2 - 3 } Sim & Pública & & Privada \\
\cline { 2 - 3 } Não & 19,2 & & 39,4 \\
\hline
\end{tabular}

Quanto à aprendizagem de línguas estrangeiras, é maior a porcentagem de alunos de escolas privadas que freqüentam cursos especializados refletindo, possivelmente, seu maior poder aquisitivo:

Tabela 3.8.14: Local de aprendizado de línguas, por tipo de escola

\begin{tabular}{|c|c|c|}
\hline & Pública & Privada \\
\hline Curso & 32,5 & 46,2 \\
\hline Escola & 55,0 & 46,2 \\
\hline Sozinho & 7,5 & - \\
\hline Na própria Internet & 2,5 & - \\
\hline De outra maneira & 2,5 & 7,7 \\
\hline
\end{tabular}

É enorme o diferencial entre usuários de e-mail, comparando-se os alunos de escolas privadas e públicas: 
Tabela 3.8.15: Utilização de e-mail, por tipo de escola

\begin{tabular}{|c|c|c|}
\hline & Pública & Privada \\
\hline Sim & 36,6 & 60,6 \\
\hline Não & 63,4 & 39,4 \\
\hline
\end{tabular}

A intensidade, porem, é bastante similar:

Tabela 3.8.16: Freqüência de verificação do e-mail, por tipo de escola

\begin{tabular}{lcc}
\hline \hline & Pública & Privada \\
\cline { 2 - 2 } 1 vez ao dia & 22,9 & 20,0 \\
Mais de 1 vez ao dia & 9,4 & 10,0 \\
1 vez por semana & 32,3 & 25,0 \\
Mais de 1 vez por semana & 22,9 & 30,0 \\
1 vez ao mês & 8,3 & 15,0 \\
Nunca & 4,2 & - \\
\hline
\end{tabular}

Observa-se a mesma situação, quanto ao conhecimento de pessoas pela Internet:

Tabela 3.8.17: Conhecimento de pessoas pela Internet, por tipo de escola

\begin{tabular}{|c|c|c|}
\hline & Pública & Privada \\
\hline Sim & 68,8 & 70,0 \\
\hline Não & 31,3 & 30,0 \\
\hline
\end{tabular}

Os alunos de escolas públicas, que em geral têm renda mais baixa, ao usar a Internet tendem, naturalmente, a conhecer pessoas de renda mais alta ou equivalente, enquanto esta tendência diminui, entre os alunos de escolas privadas:

Tabela 3.8.18: Nível socioeconômico das pessoas que conheceu pela Internet, por tipo de escola

\begin{tabular}{lccc}
\hline \hline & Pública & & Privada \\
\cline { 2 - 2 } Nível socioeconômico mais alto & 42,3 & & 36,4 \\
Mesmo nível socioeconômico & 55,8 & & 63,6 \\
Nível socioeconômico mais baixo & 1,9 & - \\
\hline
\end{tabular}

Como vimos anteriormente, em geral quanto maior a renda, menor a participação em grupos de chat, o que também ocorre entre os alunos de escolas privadas e públicas: 
Tabela 3.8.19: Participação em chats, por tipo de escola

\begin{tabular}{lccc}
\hline & & \\
\cline { 2 - 3 } Sim & Pública & & Privada \\
\cline { 2 - 3 } Não & 61,1 & & 40,0 \\
& 38,9 & & 60,0 \\
\hline
\end{tabular}

A expectativa de que a computação ajuda na obtenção de emprego é quase consensual:

Tabela 3.8.20: Opinião sobre a importância do domínio de computação na conquista de emprego, entre usuários de microcomputador, por tipo de escola

\begin{tabular}{lccc}
\hline & & \\
\cline { 2 - 3 } $\operatorname{Sim}$ & Pública & & Privada \\
\cline { 2 - 3 } Não & 99,0 & 94,4 & 9,4 \\
\hline
\end{tabular}

\section{9 - Estação Futuro}

Como indicamos anteriormente, as Estações Futuro são telecentros instalados pela ONG Viva Rio em várias favelas do Rio de Janeiro. Com uma média de 25 computadores em cada Estação, elas oferecem acesso de alta velocidade, cursos de informática e vários serviços para a comunidade.

A seguir, analisamos os dados de duas favelas que possuem Estação Futuro, para avaliar sua importância no universo de usuários de microcomputador.

Do total desses usuários, praticamente três quartos conhecem as Estações Futuro: 


\section{Gráfico 3.9.1: Nível de conhecimento da Estação Futuro}

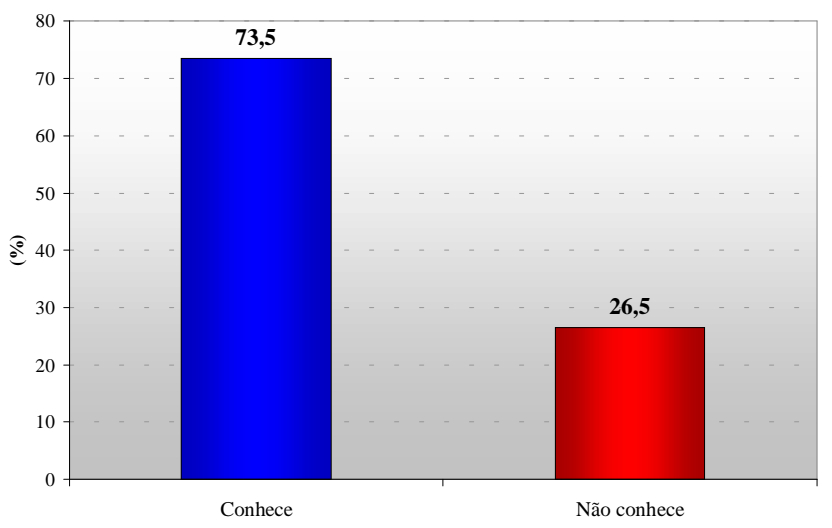

No caso da Favela da Rocinha, o número de pessoas que conhecem as Estações Futuro é bastante superior ao da favela da Maré, o que se deve ao fato desta última ser maior (na verdade, um complexo de favelas), ecologicamente mais (localiza-se em território plano, enquanto a Rocinha fica no morro) e dividida internamente pelo tráfico, que não permite a livre circulação dos moradores.

Gráfico 3.9.2: Percentual de pessoas que conhecem a Estação Futuro, por comunidade

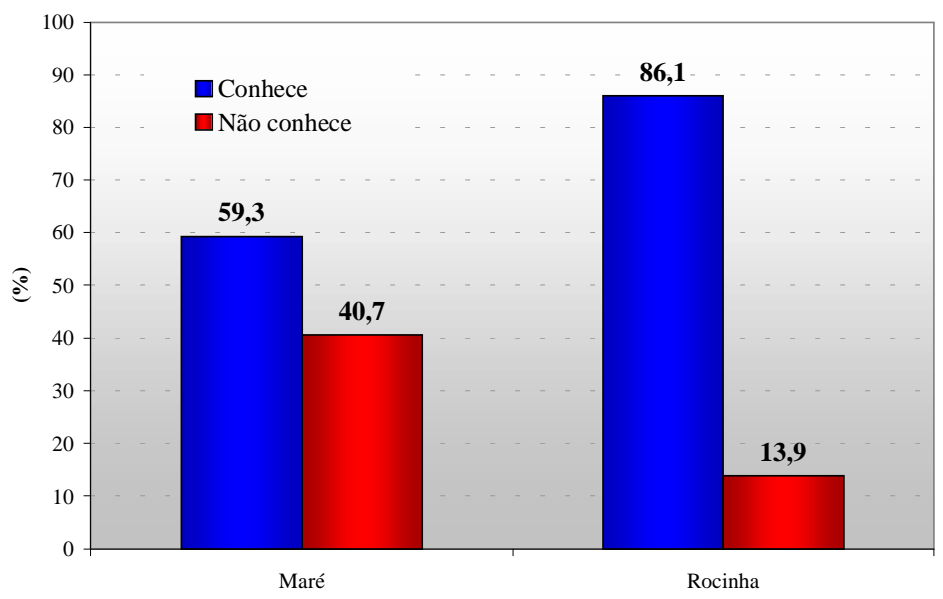

Do total de usuários de microcomputador, 60\% utilizam a Estação Futuro. 
Gráfico 3.9.3: Nível de utilização da Estação Futuro

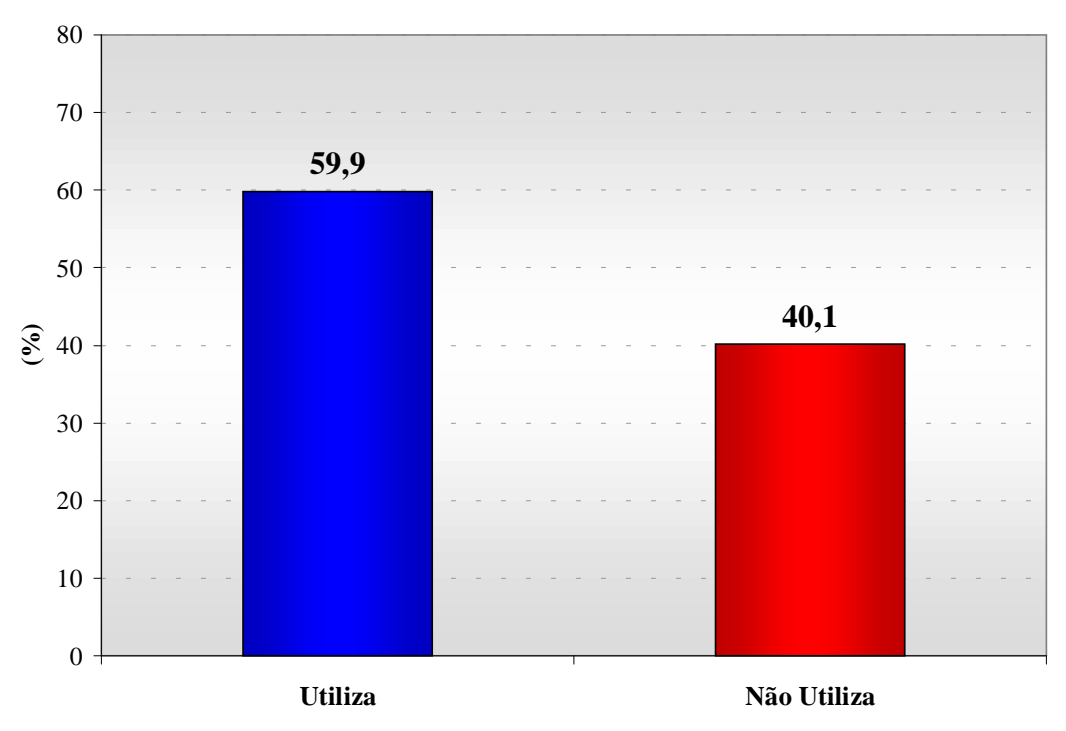

Novamente na favela da Rocinha, o percentual de usuários da Estação Futuro é superior:

Gráfico 3.9.4: Percentual de pessoas que utilizam a Estação Futuro, por comunidade

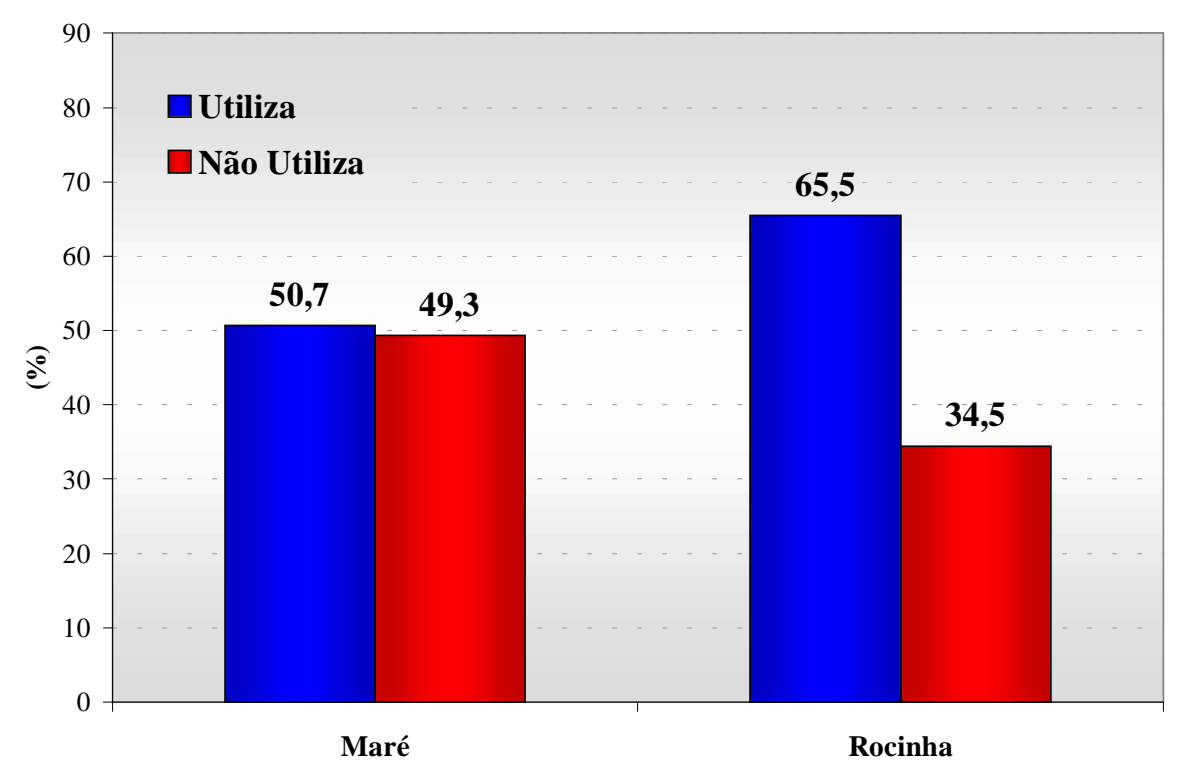

O uso das Estações Futuro apresenta a mesma diferença de resultados entre os sexos, quando se compara com o resultado do universo geral de usuários. Isto reflete a distribuição geral de usuários, e também indica a dificuldade das Estações Futuro para mudar essa tendência: 
Gráfico 3.9.5: Percentual de pessoas que utilizam microcomputador e a Estação Futuro, segundo o sexo

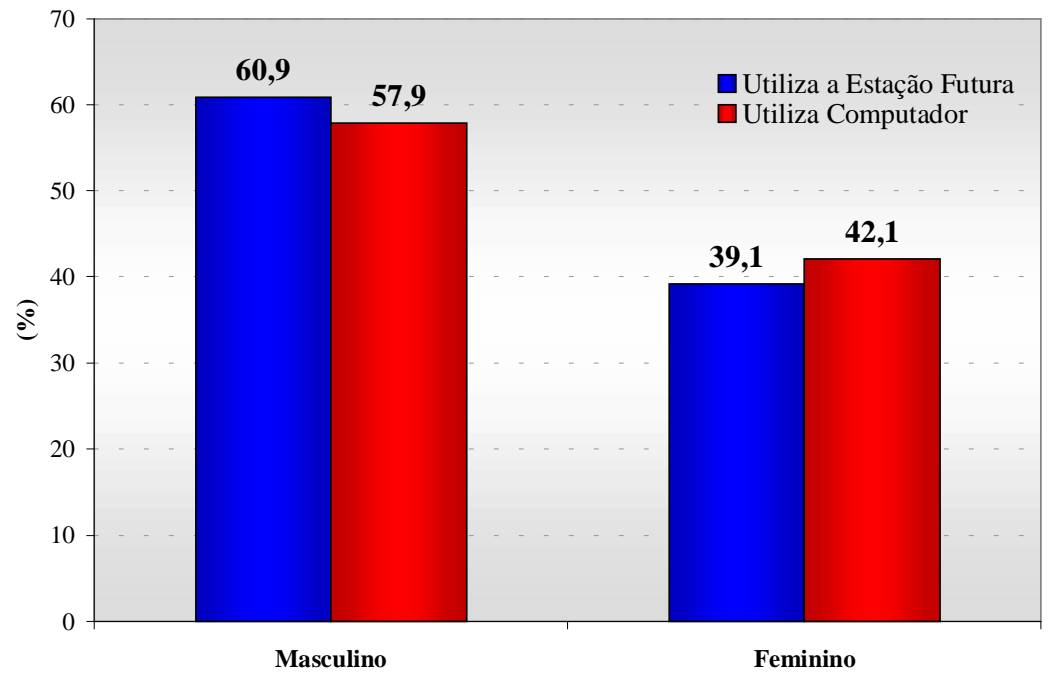

Nota: o universo é o total de usuários da Estação Futuro

Isto vale igualmente para a população negra que, com um nível de renda média mais baixo, tem dificuldades de pagar os custos de utilização da Estação Futuro.

\section{Gráfico 3.9.6: Percentual de pessoas que utilizam microcomputador} e a Estação Futuro, segundo a cor/raça

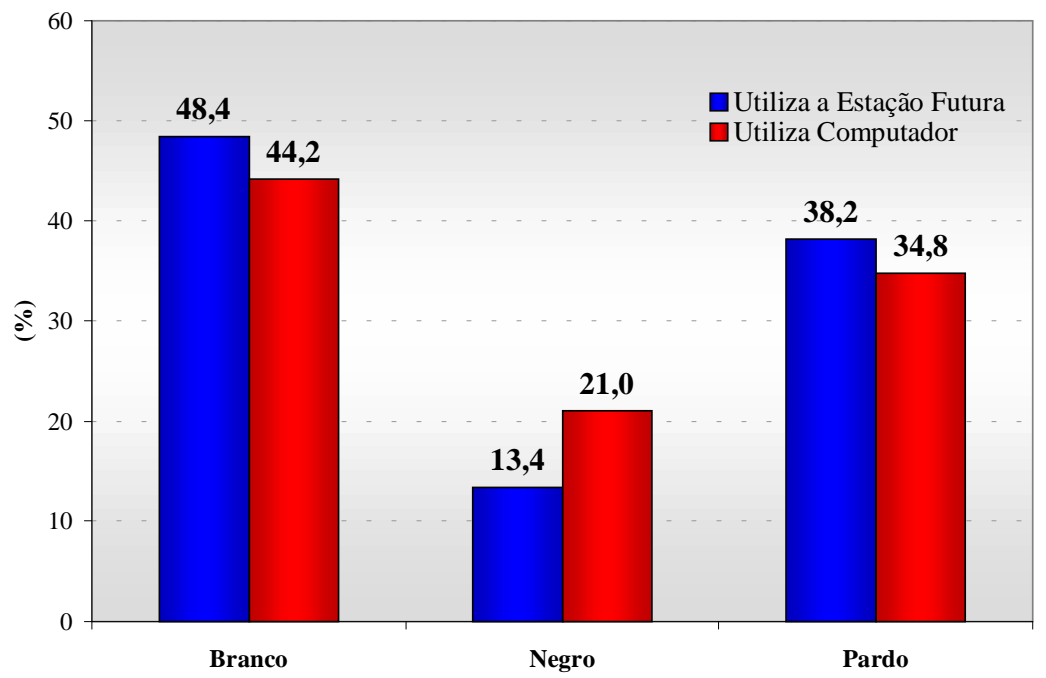

Em relação à faixa de idade, as Estações Futuro atraem particularmente os mais jovens: 
Gráfico 3.9.7: Percentual de pessoas que utilizam microcomputador e a Estação Futuro, segundo a faixa de idade

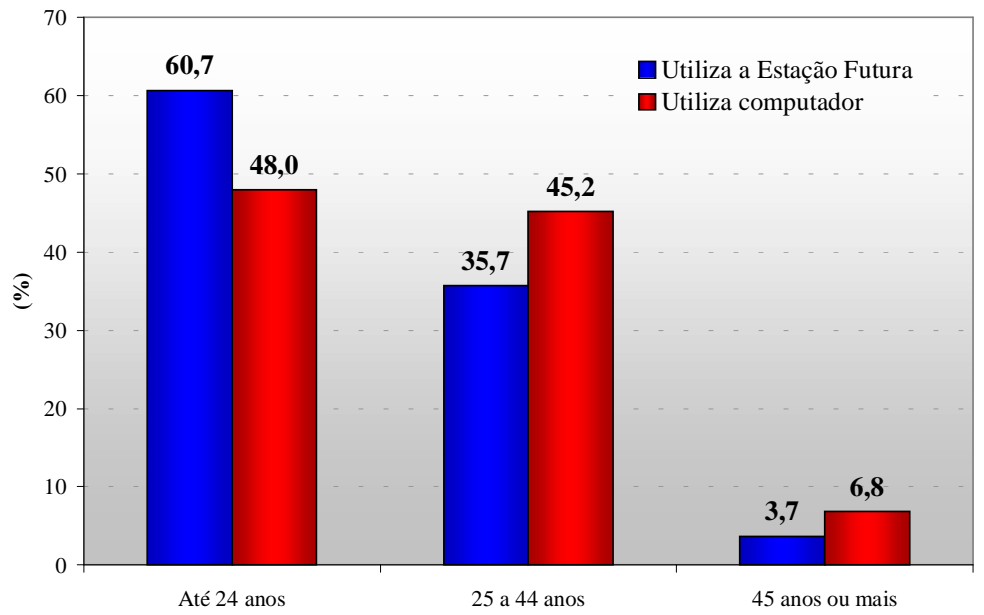

Vale ressaltar que esses jovens geralmente são dependentes dos pais ou familiares, e possivelmente muitos deles não trabalham:

Gráfico 3.9.8: Percentual de pessoas que utilizam microcomputador e a Estação Futuro, segundo posição no domicílio

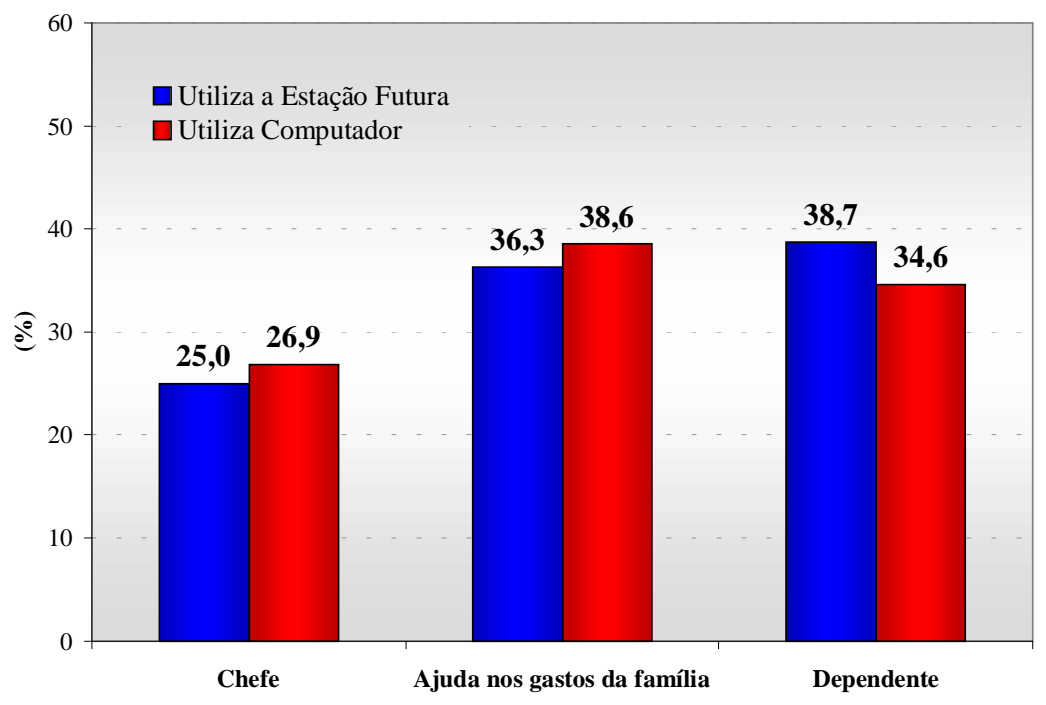

Os usuários da Estação Futuro têm uma renda familiar similar à do usuário médio de computação. Em outras palavras, as Estações Futuro expandem a disponibilidade de acesso, mas não mudam o padrão de renda dos usuários: 
Gráfico 3.9.9: Percentual de pessoas que utilizam microcomputador e a Estação Futuro, segundo a renda familiar

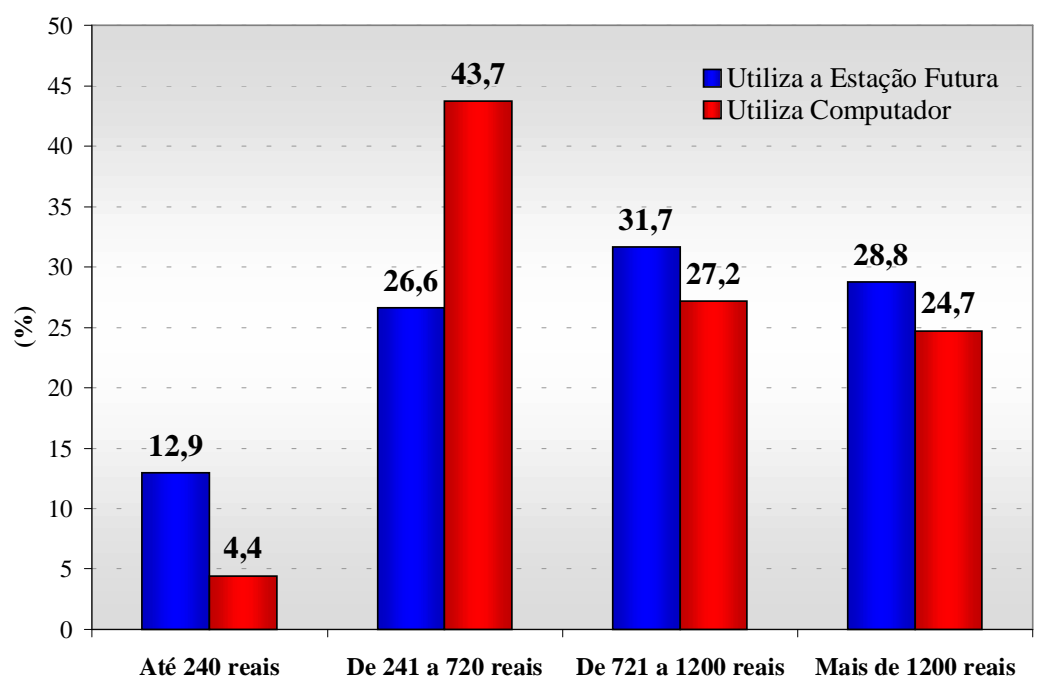

Como mostram os dois próximos gráficos, o número de usuários das Estações Futuro com posse de computador ou acesso à Internet é menor do que a média geral, mais ainda assim é uma porcentagem relevante. Mesmo o proprietário de computador procura a Estação Futuro, pela qualidade de conexão com a Internet e pela disponibilidade de impressora.

Gráfico 3.9.10: Percentual de pessoas que utilizam microcomputador e a Estação Futuro, segundo posse de micro no domicílio

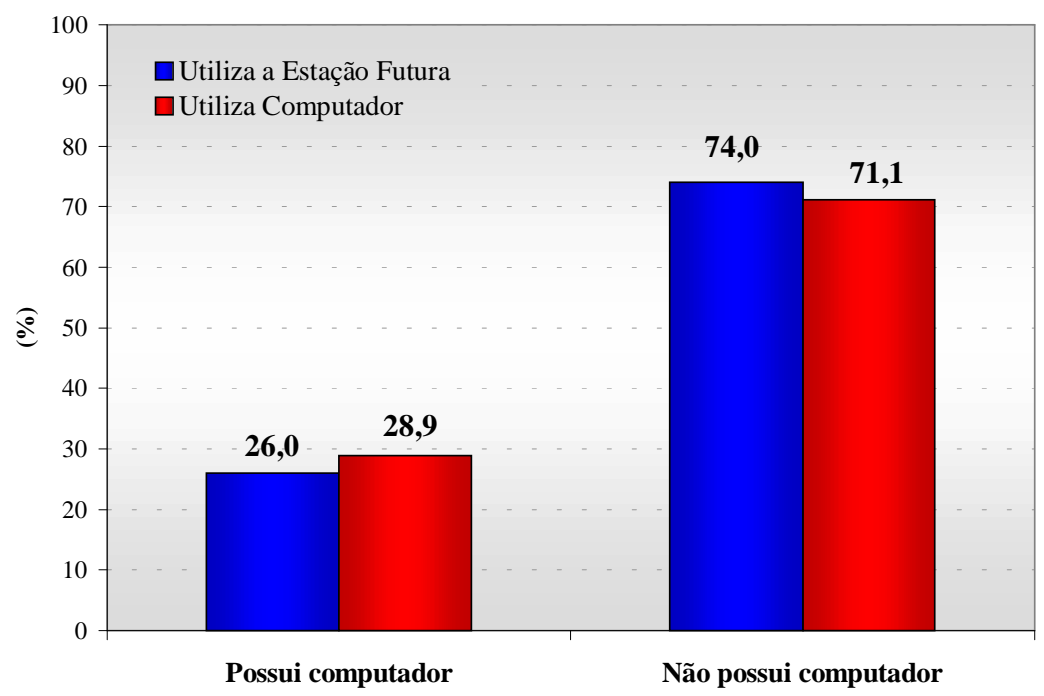


Gráfico 3.9.11: Percentual de pessoas que utilizam microcomputador e a Estação Futuro, segundo posse de Internet no domicílio

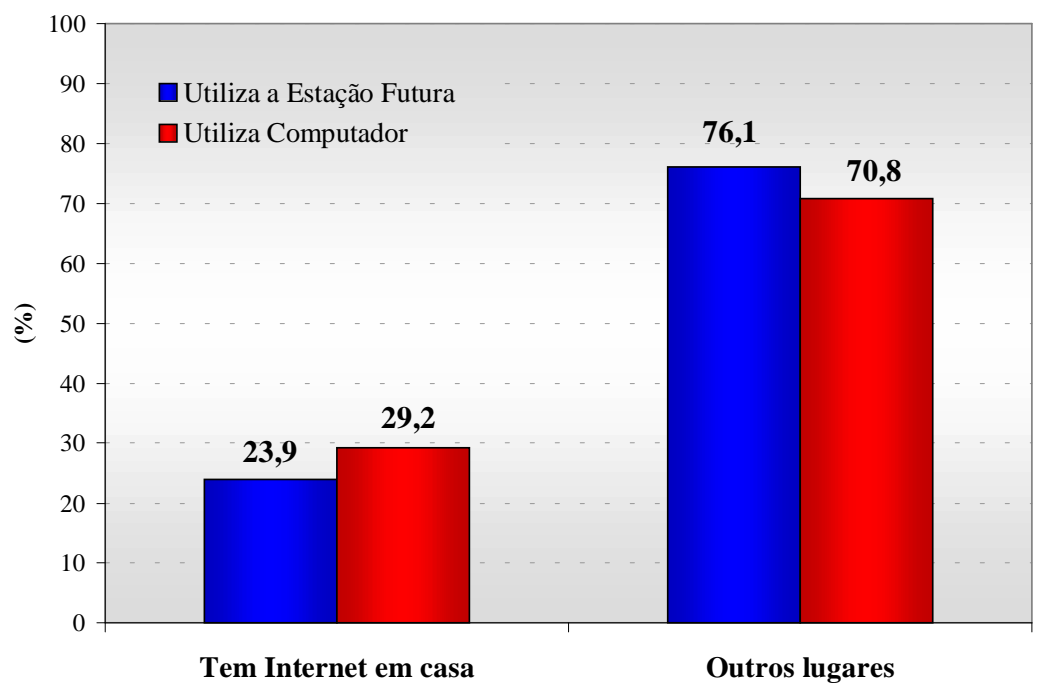

Em suma, as Estações Futuro aumentam o universo de acessso, mas não modificam o padrão do perfil do usuário. 


\section{4 - Conclusões: Políticas públicas e inclusão digital}

Levando-se em consideração os achados da pesquisa e a bibliografia internacional sobre o tema exclusão digital, impõem-se algumas conclusões sobre os objetivos da universalização do acesso à Internet e da democratização da informação. Sempre é bom lembrar que, mesmo sublinhando as limitações para se democratizar a informação não estamos, absolutamente, indicando a importância das políticas de universalização de acesso. Pelo contrário, universalizar o conhecimento básico sobre o uso de computadores e Internet é fundamental para limitar o impacto negativo que eles podem trazer para setores mais pobres. $\mathrm{Na}$ atualidade, conhecimentos básicos de computação e Internet são, cada vez mais, pré-condição de acesso ao emprego.

As políticas de universalização de acesso devem confrontar as complexidades associadas à apropriação efetiva das TICs pelos setores mais pobres da população, quais sejam:

1. O valor efetivo da informação depende da capacidade dos usuários para interpretá-la. Informação só existe em forma de conhecimento, e este depende de um longo processo de socialização, e de práticas que criam a capacidade analítica que transforma bits em conhecimento. Portanto, confrontar a exclusão digital supõe enfrentar a exclusão escolar.

2. Nos países em desenvolvimento, as políticas de universalização do acesso à Internet serão uma quimera, se não estiverem associadas a outras políticas sociais, em particular às de formação escolar. Não haverá universalização de acesso às novas tecnologias da informação e da comunicação, sem universalização de outros bens sociais. Em países em desenvolvimento, onde as taxas de analfabetismo funcional são altíssimas (no Brasil, calcula-se em torno do 30\%), a luta contra as diversas carências de acesso a serviços públicos (educação, saneamento, segurança, saúde, serviços jurídicos) exige uma visão complexa da luta contra a exclusão digital. Obviamente, isto não significa que se 
deva esperar que se chegue a erradicar o analfabetismo para desenvolver políticas de inclusão digital. Não podemos esquecer que a luta por essa inclusão é uma batalha contra o tempo. As novas tecnologias da informação aumentam a desigualdade social, de forma que a universalização do acesso não é mais do que a luta para nivelar as condições de acesso ao mercado de trabalho. As exigências da economia e os novos empregos obrigam a convivência de políticas publicas que trabalham simultaneamente com diferentes setores sociais e ritmos desiguais de universalização de serviços públicos. Porém, não se pode desconhecer a imbricação das políticas sociais, e o fato de que o sucesso final destas depende de um programa integrado de universalização dos vários serviços públicos. No curto prazo, as políticas de inclusão digital, que terão impacto apenas sobre uma parte da população mais pobre, devem definir claramente quais os públicos-alvo prioritários.

3. Como foi indicado anteriormente é fundamental definir as prioridades dos públicos-alvo. Como indica a pesquisa, em principio os telecentros em bairros pobres são utilizados pelos setores da comunidade que já possuem um nível básico de escolaridade e um maior nível de ingresso. Uma política de universalização do acesso à Internet deve ter como objetivo prioritário a rede escolar, único local onde pode ser efetivamente atingido o conjunto da população. A pesquisa indica ainda que o local de trabalho é um fator importante de inclusão digital, e políticas de inclusão digital deveriam criar incentivos para que um maior número de empresas usuárias de informática e Internet ofereçam cursos de computador e Internet a todos os seus empregados.

4. As escolas são instrumentos centrais para socializar as novas gerações na Internet. Isto, porém, não implica: a) transformar a telemática em instrumento privilegiado do sistema educativo; b) realizar sobreinvestimentos, com um número exagerado de computadores, por escola. Os resultados da pesquisa sobre o impacto do uso da informática e da Internet nas escolas são contraditórios. A adaptação dos professores a este novo instrumento é um longo processo, que não pode ser dissociado da melhoria geral da formação profissional. O desenvolvimento de softwares adequados, a readaptação do 
sistema pedagógico e o desenvolvimento de disciplinas de ensino crítico e de uso da telematica serão, na maioria dos países em desenvolvimento, um processo necessariamente longo. Até lá, o papel dos laboratórios escolares de telemática deve ser o de introduzir os alunos no uso destes instrumentos, capacitando-os no conhecimento dos programas básicos, de forma a facilitar sua futura inserção no mercado de trabalho e motivá-los para o uso de novas tecnologias. Considerando-se tais limites, é suficiente oferecer cursos de telemática em um único ano durante o curso do ensino fundamental e, eventualmente, novamente, durante o ensino médio.

5. Uma perspectiva similar deve ser aplicada, em relação ao objetivo de democratização da informação. $O$ valor efetivo da informação depende da capacidade de interpretação do usuário. Um nível mais alto de escolaridade é fundamental para maximizar o potencial oferecido pela Internet. A promoção de sites com conteúdos específicos para populações de baixa renda, ou em línguas nativas, pode ter um papel importante para compensar as dificuldades de acessar conteúdos produzidos para públicos de classe média ou com conhecimento de outras línguas. Mas nesta área, apesar do reconhecimento do problema por organismos dedicados à inclusão digital, os avanços têm sido muito limitados. Na atualidade, o financiamento da maioria dos novos conteúdos disponíveis na Internet é feito com capital de risco, que supõem um retorno de seu investimento. Boa parte do mercado-alvo desses conteúdos é constituída pela classe média.

6. O desenvolvimento de telecentros, isto é, de cabinas de acesso público à Internet, é parte importante em qualquer política de universalização de serviços. Apesar dos esforços de ONGs para desenvolver telecentros comunitários, estas iniciativas têm tido um impacto quantitativo praticamente residual, embora cumpram uma importante função de efeito-demonstração e possam ter, por vezes, importante papel nas comunidades onde se localizam. Porém, a universalização do acesso passa fundamentalmente pelas políticas publicas eventualmente associadas ao setor privado e a incentivos ao mercado. $\mathrm{O}$ setor privado tem tido um papel relevante na criação de telecentros, que em geral 
utilizam equipamentos de baixo custo, programas piratas e são administrados pela família proprietária, como indica o exemplo peruano. ${ }^{13}$ Mas as políticas públicas são fundamentais para atingir uma escala que iniciativas voluntárias não têm condições de obter. As políticas públicas de universalização de acesso exigem soluções criativas de licitação de serviços para as comunidades mais pobres, abrangendo serviços subsidiados realizados por empresas privadas, assim como por associações comunitárias e/ou ONGs.

13 - Cf.. Proenza, F. J.; Bastidas-Buch, R.; Monter, G. Telecenters for Socioeconomic and Rural Development in Latin America and the Caribbean. Washington, D.C.: FAO/ITU/IADB, May 2001, http://www.iadb.org/ict4dev/telecenters/fullrep.pdf 


\section{Anexo 1: Representatividade do universo da pesquisa}

O levantamento dos dados da pesquisa incluiu dois surveys com objetivos e estratégias de construção de amostra diferenciados. O primeiro survey, cujo principal objetivo era verificar o nível de exclusão digital nas comunidades pobres do município do Rio de Janeiro, se concentrou em quatro dimensões básicas: posse de microcomputadores, utilização de microcomputadores, utilização de Internet e utilização de e-mail. Outro objetivo a ser alcançado pelo primeiro suvvey seria o de mostrar o impacto da presença da Estação Futuro na inclusão digital local. Definiu-se, assim, que o universo da pesquisa seria constituído de moradores de favelas do município do Rio de Janeiro, com idades entre 15 e 65 anos.

Para atender a tais objetivos, criou-se uma amostra capaz de proporcionar uma visão geral da exclusão digital no conjunto de favelas do município do Rio de Janeiro, com a possibilidade de serem extraídos indicadores para dois grupos de favelas: as que contam com Estação Futuro e as que não contam com Estação Futuro. Assim, foram selecionadas duas favelas que possuem Estação Futuro: Rocinha e Maré, esta última representada por 8 grandes comunidades (Parque Maré, Nova Holanda, Baixa do Sapateiro, Parque União, Rubens Vaz, Morro do Timbau, Praia de Ramos, Roquete Pinto), e 18 favelas que não têm Estação Futuro: Alto da Bela Vista, Canal do Anil, Mangueira, Fazenda Coqueiro, Formiga, Favela do Jacaré (Santíssimo), Jacarezinho, Joaquim Queiroz, Morro da União, Nova Brasília, Parque Alegria, Parque Royal, Parque São Jorge, Pavão-Pavãozinho, Vila Cruzeiro, Vila Rica de Irajá, Vila São Jorge, Vila Vintém.

As favelas selecionadas para a amostra obedeceram a critérios de localização, tamanho da população e renda média, para que todos os tipos de favelas fizessem parte da seleção. A amostra total para este survey incluiu 1510 pessoas moradoras das comunidades listadas acima, e as entrevistas foram realizadas em entradas e saídas das favelas, para que o processo de obtenção de informações fosse mais rápido. Este survey é representativo da população de favelas do município do Rio de Janeiro e, por 
extensão, da população pobre do município, porém não é representativo da população pobre do Grande Rio, ou do estado do Rio de Janeiro.

O segundo survey teve um objetivo complementar: a pesquisa deveria definir, com mais precisão que a anterior, o perfil de utilização de microcomputador, de acesso à Internet e de utilização de e-mail. Portanto, definiu-se que o universo da pesquisa seria composto por moradores de favelas do município do Rio de Janeiro, com idades entre 10 e 65 anos, que utilizam microcomputadores.

O objetivo do segundo survey também foi o de dar condições para que os resultados permitissem diferenciar a segmentação entre as favelas. Para isso, foram realizadas pesquisas em seis favelas, uma de renda média mais alta, três de renda média intermediária e duas de renda média baixa, utilizando-se um questionário mais detalhado. No primeiro caso, foi incluída a favela da Rocinha; no segundo caso, as favelas da Maré - um conglomerado representado pelas mesmas 8 favelas do primeiro survey, muitas delas segmentadas pelo tráfico de drogas, com setores internos bastante diferenciados em termos de renda - , Rio das Pedras e Morro Dona Marta; e no terceiro caso foram escolhidas as favelas de Jacarezinho e Jacaré (Senador Camará).

O desenho amostral permite uma leitura dos dados para todo o conjunto de favelas, de maneira agregada. A amostra total para este survey também foi de 1510 pessoas moradoras das comunidades listadas acima, que utilizam microcomputadores, e as entrevistas também foram realizadas em entradas e saídas das favelas, para que o processo de obtenção da informação fosse mais rápido. Este survey é representativo da população de usuários de microcomputador, das favelas do município do Rio de Janeiro. 


\section{$\underline{\text { Anexo } 2 \text { - Perfil dos Grupos Focais }}$}

Foram organizados oito Grupos Focais com as comunidades da Rocinha e da Maré: quatro deles eram constituídos de moradores da Rocinha, três de moradores da Maré e um de lideranças comunitárias ${ }^{14}$ de ambas as favelas. Os grupos se reuniram no período de 10 a 14 de novembro de 2003 , e foram planejados previamente, de acordo com faixa etária e sexo, com exceção do grupo que envolvia as lideranças. No quadro abaixo, está indicada a configuração de cada grupo:

\begin{tabular}{ccccc}
\hline Grupos & Faixa Etária & Sexo & Comunidade & Tipo \\
\hline \hline 1 & 12 a 16 anos & Homens e Mulheres & Rocinha & Usuários de Internet \\
2 & 16 a 22 anos & Homens e Mulheres & Maré & Usuários de Internet \\
3 & 22 a 35 anos & Homens & Rocinha & Usuários de Internet \\
4 & 22 a 35 anos & Mulheres & Rocinha & Usuários de Internet \\
5 & mais de 35 anos & Homens & Maré & Usuários de Internet \\
6 & mais de 35 anos & Mulheres & Rocinha & Usuários de Internet \\
7 & 18 a 25 anos & Homens e Mulheres & Maré & Não usuários de Internet \\
8 & - & - & Maré e Rocinha & Lideranças \\
\hline
\end{tabular}

Nas discussões realizadas nos Grupos Focais, 37\% do total dos participantes dos grupos possuem computador em casa. Comparando-se o grupo de mulheres com mais de 35 anos e o de jovens não-usuários da Internet, constata-se uma queda na aquisição de computador. No grupo de mulheres, apenas $22 \%$ possuem o equipamento e nenhum dos jovens não-usuários tem micro:

\footnotetext{
${ }^{14}$ A expressão "lideranças comunitárias" refere-se a pessoas que trabalham em instituições voltadas para a melhoria da qualidade de vida na comunidade e abrange tanto a representação da própria comunidade, em geral ligada às associações de moradores, como também organizações não-governamentais e instituições comunitárias sem fins lucrativos.
} 


\section{Pessoas que participaram das discussões em grupo}

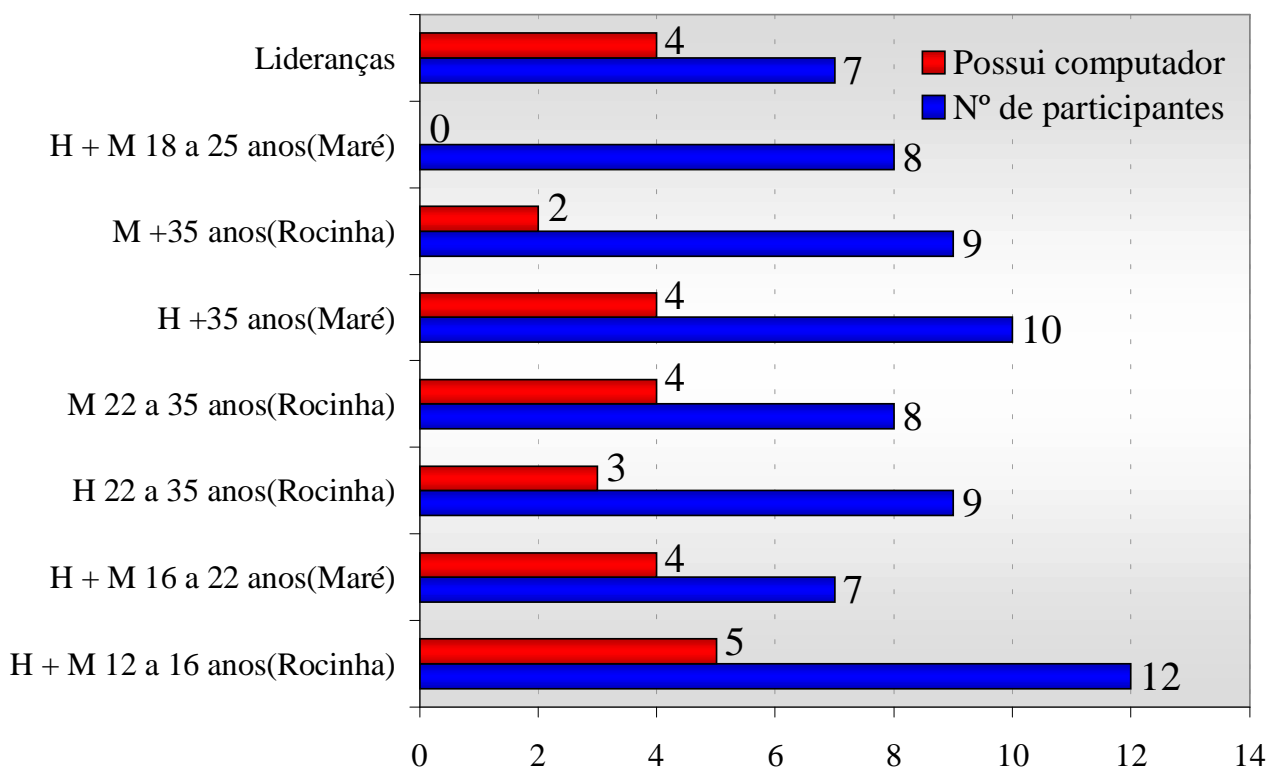

Cada grupo contou com a participação de sete a doze pessoas, que foram convidadas através de contato telefônico e por carta (modelo em anexo) ou através de contato telefônico feito a partir do cadastro de usuários da Estação Futuro. Os grupos da Rocinha se reuniram na Associação de Moradores (AMABB), localizada na Travessa Palmas, n³, na própria comunidade. Os grupos da Maré, na Congregação Presbiteriana de Bonsucesso, localizada na Rua General Galiene, $n^{0} 122$, Bonsucesso, e o grupo das lideranças se reuniu na sede do Viva Rio, Glória.

Houve uma tolerância de 20 minutos antes do início das reuniões dos grupos para a chegada dos retardatários, evitando-se a entrada de pessoas atrasadas, durante a reunião. Inicialmente, foi feita a apresentação da equipe e falou-se sobre o objetivo do trabalho. 